\title{
Marco jurídico de las finanzas
}

\section{Elvia Arcelia QUINTANA ADRIANO}

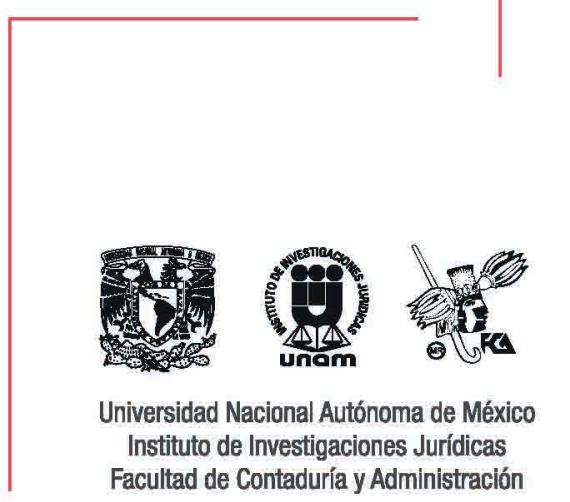


Doctora en Derecho por la UNAM. Profesora titular por oposición de Derecho mercantil, Sociedades mercantiles, y Títulos

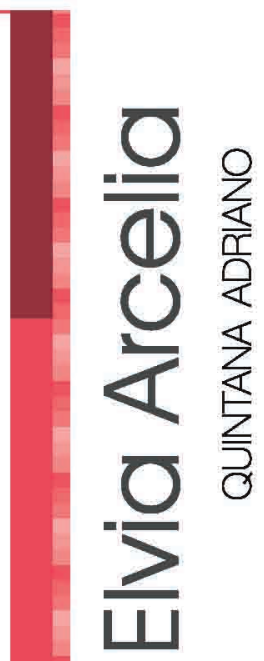
y operaciones de crédito en la Facultad de Derecho; así como de Derecho financiero en la División de Estudios de Posgrado de la Facultad de Contaduría y Administración de la UNAM. Distinción Catedrática UNAM; reconocimiento Sor Juana Inés de la Cruz 2005; Premio Universidad Nacional en Ciencias de la Administración 2006; reconocimiento Mérito Jurídico de la Cámara Municipal de Ribeirão Preto, São Paulo, Brasil. Emérita en la UNAM.

Es investigadora titular $C$ en el Instituto de Investigaciones Jurídicas de la UNAM y nivel III, desde 2006, en el Sistema Nacional de Investigadores del Conacyt.

Entre sus obras más recientes destacan: Ciencia del derecho mercantil: teoná, doctrina e instituciones; El comercio exterior de México: marco junídico, estructura y politica; Concursos mercantiles: doctrina, ley y jurisprudencia; Derecho mercantil, evolución histórica, México 1325-2005, e Instituciones mercantiles (CD interactivo). 
MARCOJURÍDICO DE LAS FINANZAS 


\section{INSTITUTO DE INVESTIGACIONES JURÍDICAS}

\section{Serie Estudios JuRídicos, núm. 325}

\section{GOORDINACIÓN EDITORIAL}

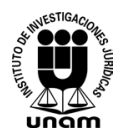

Lic. Raúl Márquez Romero Secretario Técnico

\author{
Lic. Wendy Vanesa \\ Rocha Cacho \\ Jefa del Departamento \\ de Publicaciones
}

Dr. José Ricardo Méndez Cruz Secretario de Divulgación

y Fomento Editorial

Mtro. Víctor Alejandro Hernández Arteaga

Coordinador editorial

Iván Escoto Mora

Cuidado de la edición

Iván Escoto Mora

José Antonio Bautista Sánchez

Formación en computadora

Roberto Zavaleta Cornejo

Apoyo editorial

Edith Aguilar Gálvez

Elaboración de portada 


\section{MARCOJURÍDICO DE LAS FINANZAS}
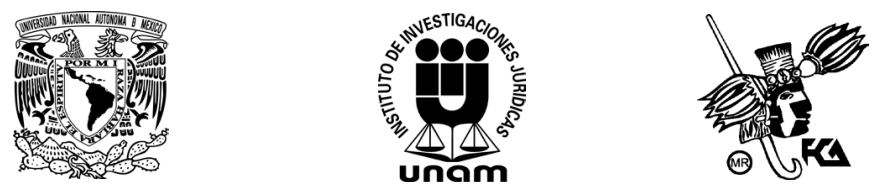

UNIVERSIDAD NACIONAL AUTÓNOMA DE MÉXICO INSTITUTO DE INVESTIGACIONES JURÍDICAS FACULTAD DE GONTADURÍA Y ADMINISTRACIÓN MÉXICO, 2018 
Primera edición: 30 de agosto de 2018

DR (C) 2018. Universidad Nacional Autónoma de México

\section{INSTITUTO DE INVESTIGACIONES JURÍDICAS}

Circuito Maestro Mario de la Cueva s/n

Ciudad de la Investigación en Humanidades

Ciudad Universitaria, 04510 Ciudad de México

Impreso y hecho en México

ISBN 978-607-30-0516-6 
A mis alumnos

de ayer, hoy y mañana 


\section{GONTENIDO}

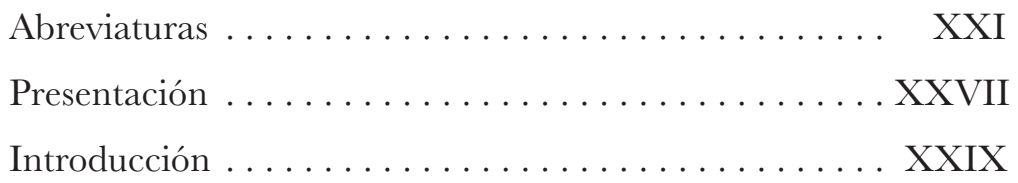

\section{PARTE GENERAL}

CapÍTUlO PRIMERO

EL SISTEMA FINANCIERO MEXICANO . . . . . . . . 3

I. Autoridades y estructura. . . . . . . . . . . . . . 3

II. Evolución regulatoria de las instituciones financieras . 5

1. Banca privada, 1897-1982 . . . . . . . . . . 8

2. Banca nacionalizada o banca pública, 1982-1990. . 10

3. El Fondo de Apoyo Preventivo a las Instituciones de Banca Múltiple (Fonapre). . . . . . . . . . . . . 12

4. Banca pública burocrática, 1988-1990........ 13

5. Banca reprivatizada, $1990 \ldots \ldots \ldots \ldots \ldots$

III. Conceptos del sistema financiero . . . . . . . . . . . 15

1. Definición de sistema financiero. . . . . . . . . 15

2. Definición de finanzas . . . . . . . . . . . 17

3. Definición de activos . . . . . . . . . . . 17

4. Definición de crédito .............. 18

5. Definición de dinero................ 18 
Capítulo segundo

ESTRUGTURA DEL SISTEMA FINANGIERO MEXICANO . . . 21

I. Banco de México . . . . . . . . . . . . . . 21

1. Antecedentes .................... 21

2. Naturaleza jurídica. . . . . . . . . . . . . . 23

3. Facultades. . . . . . . . . . . . . . . . . . . . 24

A. Junta de Gobierno. . . . . . . . . . . . . 25

B. Gobernador. . . . . . . . . . . . . . . . . . . . 26

4. Direcciones generales y direcciones . . . . . . . . 27

5. Operaciones del Banco de México. . . . . . . . . . 28

6. Obligaciones del Banco de México como órgano constitucional autónomo . . . . . . . . . . . 30

7. Estructura........................ 31

II. Secretaría de Hacienda y Crédito Público. . . . . . . . 32

1. Naturaleza jurídica. . . . . . . . . . . . . . . . . . 32

2. Facultades.................... 32

3. Estructura. ...................... 34

III. Fondos y fideicomisos públicos . . . . . . . . . . . . 36

Organismos de Fomento ................ 37

IV. Instituto de Protección al Ahorro Bancario (IPAB) . . 38

1. Ubicación y naturaleza jurídica . . . . . . . . . . 38

2. Objeto y facultades generales.............. 39

3. Atribuciones del IPAB . . . . . . . . . . . . . . . 39

4. Operaciones que no garantizará el IPAB . . . . . . . 42

5. El derecho de acceso a la información pública gubernamental, IPAB . . . . . . . . . . . . . . 42

6. Estructura..................... 43

V. Comisión Nacional para la Defensa y Protección de los Usuarios de Servicios Financieros (Condusef) . . . . . . 
1. Naturaleza jurídica. . . . . . . . . . . . . . 45

2. Objeto y facultades generales............. 45

3. Buró de entidades financieras. . . . . . . . . . 47

4. Los procedimientos que realiza la Condusef . . . . . 48

A. Procedimiento de conciliación .......... 48

B. Procedimiento de arbitraje en amigable composición y en estricto derecho . . . . . . . . . . . 49

5. Estructura . . . . . . . . . . . . . . . 50

CAPÍtulo Tercero

Comisiones de vigilancia $\ldots \ldots \ldots \ldots \ldots \ldots \ldots$

I. Comisión Nacional Bancaria y de Valores (CNBV). . 55

1. Naturaleza jurídica................... 55

2. Objeto. ....................... 55

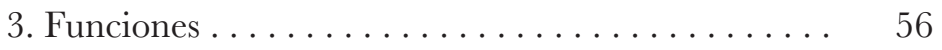

4. Obligaciones. . . . . . . . . . . . . . . . . 58

5. Entidades supervisadas. . . . . . . . . . . . . 59

A. Instituciones de crédito . . . . . . . . . . . . 59

B. Sociedades financieras populares, sociedades financieras comunitarias y organismos de integración financiera rural . . . . . . . . . . . . . . 59

C. Grupos financieros y sociedades controladoras. . 61

D. Casas de bolsa . . . . . . . . . . . . . . . . . 62

E. Bolsa de Valores. . . . . . . . . . . . . . . . . . . 63

F. Sociedades operadoras de fondos de inversión . . 63

G. Fondos de inversión. . . . . . . . . . . . . . 64

H. Sociedades auxiliares del crédito. . . . . . . . 65

I. Sofomes reguladas. . . . . . . . . . . . . . 66

J. Indeval. . . . . . . . . . . . . . . . . 67

K. Instituciones calificadoras de valores. . . . . . . 68 
6. Estructura de la GNBV . . . . . . . . . . . . 69

II. Comisión Nacional de Seguros y Fianzas (CNSF) . . . 69

1. Naturaleza jurídica................. 70

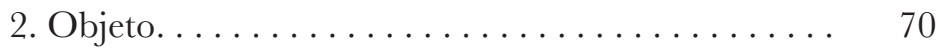

3. Funciones . . . . . . . . . . . . . 70

4. Obligaciones..................... 72

5. Ámbito de supervisión . . . . . . . . . . . 75

A. Instituciones de seguros . . . . . . . . . . 76

B. Sociedades mutualistas de seguros. . . . . . . 76

C. Afianzadoras . . . . . . . . . . . . . . 76

D. Reaseguradoras . . . . . . . . . . . . . . . . 77

E. Agentes de seguros y fianzas . . . . . . . . . . . 77

F. Intermediarios de reaseguro . . . . . . . . . . 78

G. Sociedades de servicios complementarios o auxiliares de las operaciones de seguro. . . . . . . . 78

H. Filiales de instituciones financieras del exterior. . 78

III. Comisión Nacional del Sistema de Ahorro para el Retiro (Consar) . . . . . . . . . . . . . . . . 79

1. Naturaleza jurídica . . . . . . . . . . . . . . . 79

2. Objeto. . . . . . . . . . . . . . . 79

3. Funciones .................... 80

4. Obligaciones................... 80

5. Instituciones de ahorro. . . . . . . . . . 80

A. Sociedades administradoras de fondos para el re-

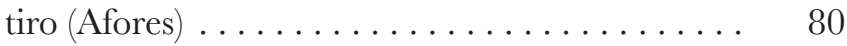

B. Sociedades de inversión especializadas para el manejo de fondos para el retiro (Siefores) ...... 81 


\section{PARTE ESPEGIAL \\ LEGISLATIVA}

CAPÍTUlO GUARTO

ESTRUCTURA JURÍDICA QUE RIGE AL SISTEMA

FINANCIERO MEXICANO. LEYES MARCO

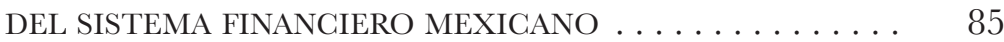

I. Constitución Política de los Estados Unidos Mexicanos, artículos que fundamentan la regulación de las finanzas ............................ 85

1. Ley del Banco de México y su Reglamento . . . . . . . 92

A. Ley del Banco de México . . . . . . . . . . . . . . 92

B. Reglamento Interior del Banco de México . . . . 92

2. Ley Monetaria de los Estados Unidos Mexicanos . . 93

3. Ley Orgánica de la Administración Pública Federal. 93

Administración pública federal . . . . . . . . . . . . 93

4. Código de Comercio ................. . 96

5. Código Civil Federal. . . . . . . . . . . . . . . 97

6. Código Fiscal de la Federación. . . . . . . . . . . . . 98

7. Ley General de Sociedades Mercantiles. . . . . . . . 98

II. Leyes de las comisiones de vigilancia al sistema. . . . . . 99

1. Ley de la Comisión Nacional Bancaria y de Valores y su Reglamento (CNBV). . . . . . . . . . . . . . . 99

2. Ley de Instituciones de Seguros y Fianzas (CNSF) . 100

3. Ley de los Sistemas de Ahorro para el Retiro (Consar) . . . . . . . . . . . . . . . 101

III. Leyes de organismos de protección al sistema . . . . . 101

1. Ley de Protección al Ahorro Bancario (IPAB) . . . . 101

2. Ley de Protección y Defensa al Usuario de Servicios Financieros (Condusef). . . . . . . . . . . . . . 102 
IV. Leyes y disposiciones de aplicación general . . . . . . . 103

1. Banca comercial ... . . . . . . . . . . . . . . 103

A. Ley de Instituciones de Crédito. . . . . . . . . . . 103

B. Ley para Regular las Agrupaciones Financieras . 104

C. Ley General de Títulos y Operaciones de Crédito. 104

D. Ley General de Organizaciones y Actividades Auxiliares del Crédito . . . . . . . . . . . . . . . . . . . . 105

E. Ley para Regular las Sociedades de Información Crediticia .................... 105

F. Ley para la Transparencia y Ordenamiento de los Servicios Financieros . . . . . . . . . . . . . . . 106

G. Ley de Uniones de Crédito . . . . . . . . . . . . . 107

2. Banca de desarrollo . . . . . . . . . . . . . . . . 107

A. Ley del Desarrollo Rural Sustentable . . . . . . . 107

B. Ley de Fondos de Aseguramiento Agropecuario y Rural. . . . . . . . . . . . . . . . . . . 108

C. Ley Orgánica de la Financiera Nacional de Desarrollo Agropecuario Rural, Forestal y Pesquero. 110

D. Ley Orgánica de Nacional Financiera . . . . . . . 111

E. Ley Orgánica de Sociedad Hipotecaria Federal . 111

F. Ley Orgánica del Banco del Ahorro Nacional y Servicios Financieros . . . . . . . . . . . . 112

G. Ley Orgánica del Banco Nacional de Comercio Exterior . . . . . . . . . . . . . . . . . . . . . 113

H. Ley Orgánica del Banco Nacional de Obras y Servicios Públicos ............... 116

3. Sector bursátil. . . . . . . . . . . . . . . 116

A. Ley del Mercado de Valores . . . . . . . . . . . 116

B. Ley de Fondos de Inversión . . . . . . . . . . . . . 117

4. Leyes del sector de ahorro y crédito popular .... . . 118 
A. Ley de Ahorro y Crédito Popular . . . . . . . . . 118

B. Ley para Regular las Actividades de las Sociedades Cooperativas de Ahorro y Préstamo. . . . . . 118

C. Disposiciones complementarias .......... 119

\section{PARTE ESPECIAL \\ SECTORES DEL SISTEMA FINANGIERO MEXICANO}

\section{Capítulo QUiNTO}

SEGTOR BANGARIO . . . . . . . . . . . . . . . . . . . 123

I. Banca múltiple . . . . . . . . . . . . . . . . . . . . 123

1. Naturaleza jurídica de las instituciones de banca múltiple. . . . . . . . . . . . . . . . . 123

2. Organismos autorregulatorios bancarios . . . . . . 126

A. Concepto . . . . . . . . . . . . . . 126

B. Objeto . . . . . . . . . . . . . . . 126

C. Actividades de los organismos autorregulatorios bancarios . . . . . . . . . . . . . . . . . 128

D. Facultades de la Comisión Nacional Bancaria y de Valores respecto a los organismos autorregulatorios bancarios. . . . . . . . . . . . . . . . . . 128

3. Servicio de banca y crédito

A. Captación de recursos del público en el mercado nacional...................... 130

B. Colocación de recursos en el público . . . . . . . 131

C. Operaciones pasivas . . . . . . . . . . . . . 132

D. Operaciones activas. . . . . . . . . . . . 136

E. Operaciones neutras o de servicios . . . . . . . . 138

4. Servicios de banca electrónica . . . . . . . . . . . . . 149 
A. Operaciones bancarias electrónicas . . . . . . 150

B. Nómina electrónica . . . . . . . . . . . . . . 151

C. Cajeros automáticos . . . . . . . . . . . . . 152

D. Banca telefónica . . . . . . . . . . . . . . 152

E. Bancanet (Internet) . . . . . . . . . . . . . 153

5. Banca de desarrollo ... . . . . . . . . . . . . . 153

A. Obligaciones de las instituciones de banca de desarrollo. . . . . . . . . . . . . . . . . . . . . . . . . 155

B. Concepto . . . . . . . . . . . . . . . . . . . 157

C. Objeto . . . . . . . . . . . . . . . . . . . . 157

D. Nacional Financiera, S. N. C. (Nafin) . . . . . . . 158

E. Banco Nacional de Obras y Servicios Públicos, S. N. G. (Banobras) . . . . . . . . . . . . . . 159

F. Banco Nacional de Comercio Exterior, S. N. G. (Bancomext)..................... 161

G. Sociedad Hipotecaria Federal, S. N. C. (SHF) . . 164

H. Banco del Ahorro Nacional y Servicios Financieros, S. N. C. (Bansefi). . . . . . . . . . . . . . . 166

I. Banco Nacional del Ejército, Fuerza Aérea y Armada, S. N. C. (Banjercito) . . . . . . . . . . . 168

\section{Gapítulo SEXTO}

SEGTOR ORGANIZAGIONES Y ACTIVIDADES AUXILIARES

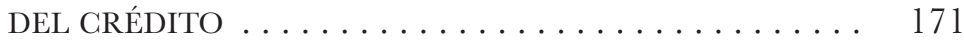

I. Organizaciones auxiliares de crédito . . . . . . . 171

II. Sociedades financieras de objeto limitado . . . . . . . 171

1. Concepto . . . . . . . . . . . . . 171

2. Su función dentro del sistema financiero mexicano. 171

3. Operaciones .................... 173 
A. Operaciones pasivas . . . . . . . . . . . 173

B. Operaciones activas. . . . . . . . . . . . . 173

C. Operaciones complementarias . . . . . . . . . 174

D. Otros ingresos financieros . . . . . . . . . . . 174

E. Incorporación de una sociedad a un grupo financiero......................... 174

III. Almacenes generales de depósito . . . . . . . . . . . . . 174

1. Objeto. . . . . . . . . . . . . . . . . . 174

2. Actividades ........................ 175

3. Tipos de almacenes . . . . . . . . . . . . . 175

IV. Actividades auxiliares del crédito . . . . . . . . . . 175

1. Centro cambiario . . . . . . . . . . . . . . . . 176

2. Sociedad financiera de objeto múltiple ........ 176

3. Obligaciones de las sociedades financieras de objeto múltiple en las operaciones de crédito, arrendamiento financiero y factoraje financiero. . . . . . . . . . 177

V. Uniones de crédito . . . . . . . . . . . . . . . . . 178

1. Objeto y naturaleza . . . . . . . . . . . . . . 178

2. Actividades . . . . . . . . . . . . . . . . . 178

VI. Casas de cambio: compra venta habitual y profesional de divisas. . . . . . . . . . . . . . . . . . . 179

1. Objeto y naturaleza . . . . . . . . . . . . . . . 179

2. Actividades . . . . . . . . . . . . . . . . . . . 180

3. La transmisión de fondos . . . . . . . . . . . . . . 181

CAPÍTUlO SÉPTIMO

SEGTOR SEGUROS Y FIANZAS . . . . . . . . . . . . . . 183

I. Instituciones de seguros y de fianzas . . . . . . . . . 183

1. Concepto . . . . . . . . . . . . . . . . . 183 
2. Agentes de seguros y de fianzas . . . . . . . . . . 184

3. Otras entidades financieras . . . . . . . . . . . 185

A. Entidades auxiliares de los intermediarios financieros . . . . . . . . . . . . . . . . . . . 185

B. Sociedades prestadoras de servicios e inmobilia-

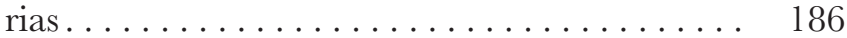

4. Sociedades de información crediticia . . . . . . . 186

A. Antecedentes . . . . . . . . . . . . . . . 186

B. Concepto . . . . . . . . . . . . . . . . . . . 187

C. Constitución . . . . . . . . . . . . . . . . . . . . 187

D. Objeto . . . . . . . . . . . . . . . . . . 188

E. Control interno . . . . . . . . . . . . . . . . . . . 188

5. Fondos de inversión . . . . . . . . . . . . . 188

A. Concepto y objeto . . . . . . . . . . . . . . 188

B. Características . . . . . . . . . . . . . . . . 188

C. Operaciones .................. 191

D. Organización. . . . . . . . . . . . . . . . . . . 192

6. Sociedades operadoras de fondos de inversión ... . 194

\section{Capítulo OCTAVO}

SECTOR DE AHORRO Y GRÉDITO POPULAR . . . . . . . . . 197

I. Objeto . . . . . . . . . . . . . . . . . . . . . 197

II. Fondo de protección . . . . . . . . . . . . . . . . . 198

III. Federaciones. . . . . . . . . . . . . . . . . . . . 200

IV. Sociedades financieras populares (Sofipos). . . . . . . 200

Objetivo ....................... 201

V. Sociedades financieras comunitarias (SFG) . . . . . . 201

VI. Sociedades cooperativas de ahorro y préstamo (Socaps). 202

Objetivo del sector . . . . . . . . . . . . . 202 


\section{PARTE INTERNACIONAL}

Capítulo nOVENO

TRATADOS INTERNAGIONALES EN MATERIA

DE COMERCIO Y SERVICIOS FINANCIEROS . . . . . . . . 209

I. Los tratados internacionales comerciales de México . . 209

II. Los tratados internacionales financieros de México. . . 211

1. Tratado de Libre Comercio de América del Norte

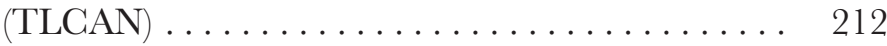

Autoridades responsables de los servicios financieros . 212

2. Acuerdo de cooperación del FMI celebrado con la OMG en $1996 \ldots \ldots \ldots \ldots \ldots . \ldots \ldots . \ldots . \ldots 213$

3. Acuerdos del Fondo Monetario Internacional y el Grupo del Banco Mundial. . . . . . . . . . . . . . 214

III. Organismos financieros internacionales. . . . . . . . 217

1. Banco Mundial. . . . . . . . . . . . . . . . . . . . 220

2. Fondo Monetario Internacional. . . . . . . . . . . . 227

3. Organización Mundial del Comercio . . . . . . . . 230

4. Cámara de Comercio Internacional (CCI) . . . . . 232

IV. Gobernanza en el sistema financiero mundial . . . . . 235

Bibliografía ........................ 243

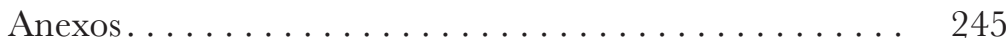




\title{
ABREVIATURAS
}

\author{
AELC Asociación Europea de Libre Comercio \\ Afore Administradoras de Fondos para el Retiro \\ AGGS Acuerdo General sobre el Comercio \\ de Servicios
}

Bancomext Banco Nacional de Comercio Exterior

Banjercito Banco Nacional del Ejército, Fuerza Aérea y Armada

Banobras Banco Nacional de Obras y Servicios Públicos

Bansefi Banco del Ahorro Nacional y Servicios Financieros

Banxico Banco de México

Bpas Bonos de protección al ahorro

Bpat Bonos de protección al ahorro con pago trimestral de interés

Brem Bonos de regulación monetaria

Caps Certificados de aportación patrimonial

CGI Cámara Internacional de Comercio

Cetes Certificados de la Tesorería de la Federación 
GFDI Comprobante fiscal digital por internet

GFF Código Fiscal de la Federación

Clabe Glave bancaria estandarizada

GNBV Comisión Nacional Bancaria y de Valores

GNSF Comisión Nacional de Seguros y Fianzas

Condusef Comisión Nacional de Defensa a los Usuarios de Servicios Financieros

Consar Comisión Nacional de Sistemas de Ahorro para el Retiro

GNUDMI Comisión de las Naciones Unidas para

el Derecho Mercantil Internacional

CPI

Título de crédito a largo plazo para financiar proyectos de desarrollo

GPO Certificado de participación ordinaria

CV Capital variable

DOF Diario Oficial de la Federación

DVP Liquidación, entrega contra pago

FARAC Fideicomiso de Apoyo al Rescate de Autopistas Concesionadas

Fipago Ley del Fideicomiso de Pago

Fobaproa Fondo Bancario de Protección al Ahorro

Fonapre Fondo de Apoyo Preventivo a las Instituciones de Banca Múltiple 
Infonavit Instituto del Fondo Nacional de la Vivienda para los Trabajadores

INPG Índice Nacional de Precios al Consumidor

IPAB Instituto de Protección al Ahorro Bancario

ISES Instituciones de Seguros Especializadas en Salud

ISR Impuesto sobre la Renta

LFI Ley de Fondos de Inversión (antes Ley de Sociedades de Inversión)

LGOAAC Ley General de Organizaciones y Actividades Auxiliares del Crédito

LGSM Ley General de Sociedades Mercantiles

LGTOG Ley General de Títulos y Operaciones de Grédito

LIC

Ley de Instituciones de Crédito

LISF

Ley de Instituciones de Seguros y Fianzas

LMV

Ley del Mercado de Valores

LPAB

Ley de Protección al Ahorro Bancario

LRASGAP Ley para Regular las Actividades

de las Sociedades Cooperativas

de Ahorro y Préstamo

LRSPBC Ley Reglamentaria del Servicio Público de Banca y Crédito

Nafin

Nacional Financiera 
NIP

Oar

PAC

PRLV

RNV

Rugd

SA

SAR

SCAPS

SFC

SHCP

SHP

SIC

Siefore

SNG

Sofipos

Sofoles
Número de identificación personal

Organismos autoregularios

Proveedor autorizado de certificaciones

Pagaré con rendimiento liquidable al vencimiento

Registro Nacional de Valores

Reglas uniformes relativas a las garantías a primer requerimiento

Sociedades anónimas

Sistemas de Ahorro para el Retiro

Sociedades cooperativas de ahorro y préstamo

Sociedades financieras comunitarias

Secretaría de Hacienda y Grédito Público

Sociedad Hipotecaria Federal

Sociedades de información crediticia

Sociedades de inversión especializadas para el manejo de fondos para el retiro

Sociedades nacionales de crédito

Sociedades financieras populares

Sociedades financieras de objeto limitado 
Sofomes

ENR

Sofomes

ER

SPEI

TEF

TIIE

TLG

TLCAN

Udis
Sociedad Financiera de Objeto Múltiple, entidad no regulada

Sociedad Financiera de Objeto Múltiple, entidad regulada

Sistema de pagos electrónicos interbancarios

Transferencia electrónica de fondos

Tasa de interés interbancaria de equilibrio

Tratado de Libre Comercio

Tratado de Libre Comercio de América del Norte

Unidades de inversión 


\section{PRESENTACIÓN}

Hablar del sistema financiero mexicano es referirse a uno de los pilares de la economía de nuestro país, ya que mediante este sistema se realizan todas las actividades financieras que giran en torno a la actividad comercial, económica, política y aun la financiera, tendente al desarrollo económico de México.

A través de este sistema se controlan las captaciones de dinero y crédito y se distribuyen, asignándose los recursos provenientes, entre otras fuentes, del ahorro y de las inversiones nacionales y extranjeras, hacia las actividades contempladas en las políticas públicas para beneficio de la población; fundamentalmente se apoya a las empresas comerciales en beneficio de los pequeños, medianos y grandes comerciantes o empresas de carácter comercial, intentando orientar su actividad hacia donde sea más efectiva y genere los mayores rendimientos.

Mediante el sistema financiero integrado con las instituciones bancarias, bursátiles, aseguradoras, afianzadoras, entre otras instituciones financieras, se fortalece, fomenta e impulsa el ahorro, la inversión y la actividad comercial del país. Es la razón por la cual desempeña un papel central en el funcionamiento y desarrollo de la economía, así como la importancia del "Marco Jurídico" que norma no sólo su estructura sino, además, su funcionamiento y operatividad.

La importancia de este sistema como eje temático radica en que permite llevar a cabo la captación de recursos económicos de personas $\mathrm{u}$ organizaciones para ponerlos a disposición de otras empresas o instituciones que lo requieran para invertirlos.

Lo anterior genera una dinámica en la que el capital es el motor principal del movimiento dentro del sistema, que contribuye y genera un mayor desarrollo y crecimiento económico, derivado de 
la inversión productiva que realizan las empresas o instituciones con el financiamiento obtenido a través del sistema financiero.

Con base en lo anterior, es importante destacar que esta obra, preparada por la profesora emérita Elvia Arcelia Quintana Adriano, profesora de asignatura en la División de Estudios de Posgrado, Maestría en Finanzas, quien habiendo participado también en el marco de actualización de los planes y programas de estudio de la Facultad de Contaduría y Administración con el proyecto de contenido que hoy tiene la asignatura, "Marco jurídico de las finanzas", mismo que fue aprobado por las instancias universitarias correspondientes, analiza el panorama del sistema financiero mexicano mediante una metodología y sistematización que facilita el aprendizaje y utilización del contenido de las normas en la vida profesional, no sólo para los contadores o administradores de empresas comerciales sino, también, para los estudiantes y profesionales de derecho, así como para cualquier otra rama de las profesiones afines que se involucren la actividad comercial.

La obra comprende tres partes fundamentales: la primera abarca el análisis del contenido general e integra esencialmente la estructura del sistema financiero mexicano, destacando a sus autoridades; la segunda parte, denominada "especial", destaca las leyes que rigen a las entidades financieras que comprenden los diversos sectores del sistema financiero mexicano; considera su naturaleza jurídica, estructura, constitución, operaciones y, por último, una parte internacional relativa a los tratados internacionales y organismos que al respecto regulan los servicios financieros.

Para la Facultad de Contaduría y Administración es satisfactorio presentar esta obra en coedición con el Instituto de Investigaciones Jurídicas.

Juan Alberto ADAM SIADE Ex director de la Facultad de Contaduría y Administración 


\section{INTRODUCGIÓN}

Las autoridades de la Facultad de Contaduría y Administración, al actualizar el programa de estudios en la currícula de la Maestría en Finanzas, actualizaron el programa de estudios de la asignatura "Marco jurídico de las finanzas".

Deseo agradecer a la Facultad de Contaduría y Administración y al Instituto de Investigaciones Jurídicas que, siguiendo el principio de la actividad académica multidisciplinaria en la Universidad Nacional Autónoma de México, me brindaron su apoyo a efecto de poder realizar esta obra, que ahora se pone en manos de los estudiantes y de los estudiosos de todas las carreras afines, principalmente a la comunidad de posgrado, Maestría en Finanzas.

Este libro desarrolla el nuevo programa de "Marco jurídico de las finanzas". Tiene por objeto facilitar, comprender e incorporar el conocimiento y manejo del cúmulo de leyes que envuelven y regulan el marco jurídico de las instituciones financieras de México, tanto en la estructura institucional del sistema como de sus autoridades, el ámbito de sus competencias, sus facultades y responsabilidades.

La estructura se analiza a partir de dos grandes partes: sus instituciones del segundo nivel, o segundo piso; así como cada uno de los subsistemas: instituciones y grupos bancarios, instituciones bursátiles, de seguros y fianzas, que integran el primer piso o nivel, que opera directamente con los usuario del sistema.

Se analiza desde el enfoque de la estructura, sus autoridades, sus operaciones; se estudia cómo interactúan las entidades del sistema en un exquisito y armonioso ritmo financiero que facilita que el dinero y el crédito fluyan al ritmo de las políticas que sostienen e impulsan el desarrollo económico del país. 
XXX

La estructura del sistema financiero mexicano, definido en la Constitución Política de los Estados Unidos Mexicanos, garantiza la seguridad de las inversiones y los ahorros nacionales y extranjeros. El Banco de México, organismo autónomo, es el canal de comunicación interna e internacional que, en coordinación con el Poder Ejecutivo a través de la Secretaría de Hacienda y Crédito Público, fundamentalmente, de acuerdo con sus respectivas facultades y funciones, son la fuente que propicia la circulación financiera que nutre la aplicación del Plan Nacional de Desarrollo y de los planes sectoriales del país, a su vez, impulsa y fomenta la creación de empresas mercantiles, en todos los campos donde se mueve dinámicamente, sea terrestre (carreteras, ferrocarriles), marítima y fluvial, aérea y espacial.

Las empresas mercantiles financieras son el motor que mueve el comercio de bienes y servicios. Es el terreno en que se desenvuelven activamente los profesionales administradores, contadores, actuarios, informáticos, abogados y todas las carreras afines. Es por ello que la Facultad de Contaduría y Administración, y el Instituto de Investigaciones Jurídicas, al impulsar proyectos editoriales con impacto multidisciplinario, cumplen con los principios de la Universidad Nacional Autónoma de México, instancias a las que agradezco por haberme apoyado para facilitar y poner en manos de los estudiantes y de los estudiosos de todas las carreras afines, principalmente de la Maestría en Finanzas, el libro que desarrolla el nuevo programa de "Marco jurídico de las finanzas". 


\section{EL SISTEMA FINANCIERO MEXICANO}

\section{AUTORIDADES Y ESTRUCTURA}

El sistema financiero mexicano está integrado, en un primer nivel, por autoridades e instituciones que conforman, encabezan y dirigen entre muchas otras actividades que implican las políticas financieras del país, el flujo de dinero y el crédito. El Banco de México es un organismo autónomo que coordinadamente con la Secretaría de Hacienda y Crédito Público, que es una entidad de la administración pública federal, encabezan y dirigen el flujo de dinero y el crédito que nutre al sistema financiero que fluye a través de diversos campos como son el bancario, el bursátil, seguros y fianzas, entidades que sirven de instrumentos para aplicar las políticas económicas, financieras y sociales del país.

Otros organismos que comprenden este primer nivel son: el Instituto de Protección al Ahorro Bancario, la Comisión Nacional para la Protección y Defensa al Usuario de Servicios Financieros y los fondos y fideicomisos públicos.

El segundo nivel se integra por varios campos de operación, como son la banca privada o comercial; la banca de desarrollo; las instituciones de seguros y fianzas; el mercado de valores o bursátil; las organizaciones auxiliares de crédito, organismos autorregulatorios bancarios y las entidades del campo de ahorro para el retiro. Todos comprendiendo un cúmulo de operaciones, negocios y títulos.

La estructura anterior está dirigida por autoridades de diferente nivel, con diferentes facultades y obligaciones que atienden la diversidad de negocios jurídicos, vigilando la exacta aplicación de la legislación financiera que norma los diversos campos señalados arriba. 
$\mathrm{Al}$ combinarse la estructura y autoridades financieras del sistema, resulta necesario conocer el amplio campo en que interactúan éstas, así como la legislación financiera, o sea, el marco jurídico que las rige, tomando en cuenta que la conjugación de instituciones y autoridades dentro de ese marco fomenta y diversifica la captación del ahorro del país y las formas en que fluyen el dinero y el crédito a través de la citada estructura.

Ese conjunto de organismos y entidades que integran el sistema financiero nacional tiene por objeto mantener el equilibrio de organizaciones y personas, sean éstas públicas, privadas o sociales, para canalizar los recursos económicos o de crédito que fluyen y circulan a través de los diferentes campos de la economía procurando el sano equilibrio del desarrollo del propio sistema, tomando en cuenta que, fundamentalmente, la captación de recursos, de la índole que sean, favorezca al país y a los mexicanos.

Las entidades integradas por instituciones financieras se rigen bajo el principio de que éstas sean instituciones transparentes que otorguen financiamientos o créditos a los diferentes sectores de la economía y la captación de recursos se realice en forma profesional; bajo la supervisión y vigilancia de las autoridades del sistema y dentro del marco jurídico establecido.

Teniendo en mente, en lo general, el planteamiento descrito arriba, procede adentrarse en el estudio y análisis de esa estructura financiera.

\section{Guadro 1. ESTRUGTURA DEL SISTEMA FINANCIERO MEXICANO}

\begin{tabular}{|c|c|c|c|}
\hline Banco de México & \multicolumn{2}{|c|}{$\begin{array}{c}\text { Secretaría de Hacienda } \\
\text { y Crédito Público }\end{array}$} & $\begin{array}{l}\text { Condusef } \\
\text { IPAB }\end{array}$ \\
\hline \multirow{5}{*}{$\begin{array}{c}\text { Fondos y fideicomisos } \\
\text { públicos }\end{array}$} & CNBV & $\frac{1}{\mathrm{CINSF}}$ & \multirow{3}{*}{\begin{tabular}{l|} 
Consar \\
Afores \\
Siefores \\
\end{tabular}} \\
\hline & Sistema bancario & Afianzadoras & \\
\hline & Sistema bursátil & $\begin{array}{l}1 \\
\text { Aseguradoras }\end{array}$ & \\
\hline & \multirow{2}{*}{$\begin{array}{c}\text { Organizaciones } \\
\text { auxiliares de } \\
\text { crédito }\end{array}$} & ISES & \\
\hline & & \multicolumn{2}{|c|}{$\begin{array}{c}\text { Sociedades mutualistas } \\
\text { de seguros }\end{array}$} \\
\hline
\end{tabular}

Fuente: Secretaría de Hacienda y Crédito Público. 


\section{EVOLUCIÓN REGULATORIA DE LAS INSTITUCIONES FINANCIERAS}

Es interesante destacar que algunos autores refieren como el principal antecedente de la banca en México al Banco de Avío, que fue una creación de Lucas Alamán, ${ }^{1}$ establecida en octubre de 1830. Dicha institución tenía como objetivo autorizar a sus directores a proveer de capital a personas y compañías que emprendieran negocios deseables y que garantizaran debidamente los fondos que se les adelantaran. ${ }^{2}$

Naturalmente, los directores del Banco no tenían autoridad para alterar la tasa de interés establecida por ley; pero sí tenían facultades discrecionales sobre los plazos, puesto que el estatuto simplemente establecía que ellos fijarían "un término regular para su reintegro". En la práctica, aunque el plazo más largo que concedieron fue de nueve años, a la mayoría de los prestatarios se les daban cinco o seis, lo que indica que los directores se comprometieron a seguir una norma de rotación lenta del capital, la que indiscutiblemente moderaría el efecto de este Banco sobre la economía.

A continuación se describen las etapas de los primeros establecimientos bancarios que existieron en nuestro país. ${ }^{3}$

1) 1884-1888: primeras instituciones de crédito. Se fundaron instituciones de emisión que tuvieron por objeto salvar las deficiencias de la escasez de metálico, animando el ritmo de los intercambios en los mercados internos que estaban

1 Quien fuera ministro de Relaciones Exteriores en el periodo de Bustamante y seriamente acusado de haber participado en la ejecución de Vicente Guerrero.

2 Quintana Adriano, Elvia Arcelia, Las cédulas hipotecarias rurales, tesis de licenciatura, México, UNAM, 1969, p. 1.

3 Ludlow, Leonor y Silva Rique, Jorge, "La primera etapa de formación bancaria (1864-1897)", Los negocios y las ganancias de la Colonia al México moderno, México, Instituto de Investigaciones Dr. José María Luis Mora-UNAM, Instituto de Investigaciones Históricas, 1993, pp. 330-359. 
limitados por la persistencia de barreras fiscales o la falta de comunicaciones rápidas y baratas.

2) 1864: control inglés sobre el mercado de la plata. En esta etapa, el país se encontraba en un periodo de grave inestabilidad política producida por la guerra de intervención y por numerosos conflictos locales. No obstante, fue una época de reordenación económica durante la cual se acrecentaron recursos internos y se introdujeron capitales externos.

Los merchant-bankers, agentes europeos y norteamericanos, juegan un papel importante en la compraventa de la plata, que mantuvo por varias décadas una función internacional clave, marcada por el patrón monetario bimetálico. De aquí el interés de los inversores y aventureros ingleses y norteamericanos por las minas mexicanas. Unos y otros sobresalieron desde la primera década del siglo en la fundación de compañías mineras, en la administración de casas de moneda y en el establecimiento de agencias comerciales.

Se funda el Banco de Londres, México y Sudamérica que funciona en nuestro país por dos décadas sin control gubernamental. Inicialmente comenzó con la introducción del azogue y la venta de plata en el exterior, más tarde abarcó el comercio con letras de cambio sobre los mercados europeos; además de otorgar préstamos a los productores nacionales, razón por la cual ha sido considerada como la primera institución emisora.

3) 1875-1883: fundación de los bancos en el estado de Chihuahua. Bajo el control militar, las regiones del norte se encontraban bajo una economía de guerra, con lo que se garantizó el tráfico mercantil y la explotación de recursos naturales, además de recibir migrantes.

Como parte de la política de movilización económica de esa etapa, la legislatura otorgó varias concesiones para fundar ban- 
cos entre los años 1875 y 1883. Así, la Cámara local autorizó en 1875 la creación del Banco de Santa Eulalia a solicitud de residentes norteamericanos. En 1878, el Mexicano y, más tarde, el Minero de Chihuahua en 1882, propiedad de la familia CreelTerrazas, que además de emitir billetes y conceder préstamos, enviaría giros, recibiría depósitos y realizaría hipotecas. Los tres fueron emisores y operaron con capitales muy reducidos. Esto dio pie para que los demás estados fundaran sus bancos.

Los préstamos refaccionarios y de avío a la minería y a la agricultura, los cubría el Banco Minero y el Mexicano, mientras que el de Santa Eulalia concedía préstamos y avíos a los pequeños y medianos mineros.

Estas instituciones bancarias nacieron tempranamente, fueron la expresión del equilibrio de una elite regional en formación que cimentó su fuerza en la relación con la frontera, movió fuentes de riqueza y protegió a la inmigración.

4) 1882-1884: segunda fase de formación de empresas bancarias. Esta etapa se desarrolló paralelamente con la expansión de la red ferroviaria. Se fundó el Banco Nacional Mexicano, que surgió por el apoyo de la clase política a la propuesta de banqueros europeos, para formar una banca mixta que realizaría las funciones de la banca comercial y a las que eran asignadas a la banca de gobierno.

5) 1848-1888: primer reajuste legal de las instituciones de crédito. En 1882, el Código de Comercio prohibió el uso del término "banco" a todas aquellas casas o empresas que no hubieran recibido las concesiones del Congreso de la Unión. Con esta medida se obligaba a las instituciones existentes a ajustarse a los términos de las nuevas disposiciones.

Bajo estas disposiciones, los bancos de Chihuahua quedaron autorizados para operar en lo que respecta a la emisión de billetes; por lo que respecta al Banco de Londres, México y Sud- 
américa, éste tuvo que modificar su concesión original y cambió su razón social por la de Banco Comercial para poder seguir operando.

6) 1888-1897: segunda etapa de formación bancaria. Se puso en práctica un régimen plural para la banca a pesar de no existir un marco legal definido.

Así, el ministerio de Hacienda otorgó concesiones para la fundación de empresas de emisión en entidades del norte y del sur.

En el norte, surgieron instituciones en Durango, Comarca Lagunera y en el Paso del Norte, hoy Ciudad Juárez, como parte del apoyo a los desarrollos del ferrocarril, industrias como el algodón y textil. El Banco de Nuevo León, denominado Banco Mercantil, fue promovido por empresarios atendiendo las peculiaridades y dinamismos económicos de la región. En el sur, el Banco de Yucatán jugó un papel importante.

En 1896, la abolición de las aduanas internas fue el antecedente de la iniciativa de regulación de los bancos existentes en el país.

\section{Banca privada, 1897-1982}

Se ha considerado que la primera etapa de la banca privada se dio en $1897,{ }^{4}$ debido a que fue el año en que se publicó la primera Ley General de Instituciones de Crédito, hasta 1982, fecha en que se expidió el decreto mediante el cual se nacionalizó la banca.

4 El 19 de marzo de 1897, en uso de las facultades otorgadas al Ejecutivo de la Unión por la Ley del Congreso de 3 de junio de 1896, el presidente Porfirio Díaz expidió y publicó en el Diario Oficial de la Federación la Ley General de Instituciones de Crédito de 1897, que es considerada la primera ley particular desprendida del Código de Comercio de 1889; esta ley fijó en México una base general para la constitución y funcionamiento de las instituciones de crédito, con lo cual se inició un nuevo periodo en la Banca Mexicana. Quintana Adriano, Elvia Arcelia, Legislación mercantil. Evolución histórica. México 1325-2005. México, Porrúa, pp. 223 y 224. 
No obstante lo anterior, proliferaron los bancos de emisión a partir de 1884 en nuestro país, antes de la expedición del mencionado cuerpo normativo.

Durante esta primera etapa la banca estaba conformada por sociedades de crédito; cada una de ellas se encontraba dedicada a una actividad determinada, tal como banca de seguros y fianzas, préstamo hipotecario, inversión, depósito, de ahorro, entre otros.

Derivado de las operaciones efectuadas por las instituciones de crédito, surgieron autoridades especiales, cuya finalidad fue la de evitar confusiones en las distintas operaciones y transacciones bancarias.

En esta etapa que se está planteando la legislación tiende a organizar el control de la actividad bancaria. También se presenta la idea de extensión del crédito mediante la creación de bancos que otorgan créditos refaccionarios y se contemplan aquellos que llevan a cabo operaciones respecto de fideicomisos; se reconoce a los grupos financieros al considerarlos como intermediarios entre la banca especializada y la banca múltiple. Se establecen sucursales y agencias de la banca mexicana en el extranjero, y también en esta etapa se consolidan, incorporan y diversifican las operaciones como parte de los servicios de banca múltiple.

Cabe destacar que el movimiento revolucionario generó una serie de calamidades para el sistema financiero mexicano, puesto que muchos instituciones bancarias quebraron a partir de 1912, y con este motivo se creó la Comisión de Cambios y Moneda, surgiendo una serie de préstamos forzosos que hicieron los gobiernos posrevolucionarios, lo que obligó a los bancos a emitir billetes sin ninguna garantía.

Durante la reforma bancaria de México que se inició en 1913 y culminó en 1925, se creó la Comisión Reguladora e Inspectora de Instituciones de Crédito, de 1915, y se declaró la caducidad de las concesiones de la mayor parte de las instituciones bancarias en 1915 . 
Las principales leyes del sistema bancario mexicano durante esta primera etapa fueron:

- Ley General de Instituciones de Crédito y Establecimientos Bancarios (16 de enero de 1925).

- Ley General de Instituciones de Crédito y Establecimientos Bancarios (29 de noviembre de 1926).

- Ley General de Instituciones de Crédito (29 de junio de 1932).

- Ley General de Instituciones de Crédito y Organizaciones Auxiliares (31 de mayo de 1941).

Podemos señalar que hasta antes de la nacionalización, la banca privada en su conjunto era un fuerte canalizador de operaciones crediticias y de viabilidad de proyectos para la industria nacional.

Por otra parte, el Estado, a través de la banca, tenía la labor de conjuntar la realización de obras y servicios, captar impuestos, generar y obtener créditos, manejar inversiones e instrumentos de deuda, capitalizar inversiones y pagar sus obligaciones.

\section{Banca nacionalizada o banca pública, 1982-1990}

El traspunte que recibió México con motivo de los choques externos en la caída de los precios del petróleo propició que se hiciera más generalizada la crisis económica del país; los bancos grandes y pequeños se vieron en la necesidad de abandonar su actividad en aras de salvaguardar el interés nacional.

Con motivo de la nacionalización de la banca, se crearon las sociedades nacionales de Crédito ( $\mathrm{SNG}$ ), que se rigieron por la Ley Reglamentaria del Servicio Público de Banca y Crédito, al tiempo que se sujetaron a los lineamientos y políticas que estableció el Banco de México; la Secretaría de Hacienda y Crédito Público (SHCP), y la Comisión Nacional Bancaria y de Seguros (hoy Comisión Nacional Bancaria y de Valores, GNBV). 
La constitución de las SNC se estableció mediante el principio de que éstas eran instituciones de derecho público, con personalidad jurídica y patrimonio propios, por lo que su duración era indefinida.

Por otra parte, se señaló en la ley que no podían participar en el servicio público de banca y crédito personas físicas o morales extranjeras ni tampoco sociedades mexicanas sin cláusula de exclusión absoluta de extranjeros.

Para enero de 1985 se publicó en el Diario Oficial de la Federación el decreto que reformaba la Ley Reglamentaria del Servicio Público de Banca y Crédito, contemplando en su artículo 2o. los tipos de instituciones bancarias: la banca múltiple y la banca de desarrollo.

La prestación del servicio de banca debía realizarse con apego a sanas prácticas y usos bancarios, con sujeción a los objetivos y prioridades del Plan Nacional de Desarrollo, buscando en todo momento alcanzar las metas específicas de cada tipo de institución, así como otras de carácter general, como las siguientes:

- Se pretendía fomentar el ahorro, buscando que la población tuviera un fácil acceso a los beneficios del servicio público de banca y crédito, canalizar eficientemente recursos financieros, y promover la participación de la banca mexicana en los mercados financieros internacionales.

- Se buscaba también un desarrollo equilibrado del sistema bancario nacional y el establecimiento de una competencia sana entre instituciones de banca múltiple, que promoviera y financiara las actividades y sectores que determinara el Congreso de la Unión, acorde con las especialidades de cada institución de la banca de desarrollo.

- Se contemplaba a la SHCP como el órgano rector de la organización y del funcionamiento de dichas instituciones, por lo que podía autorizar, oyendo la opinión del 
Banco de México y de la Comisión Bancaria y de Seguros, el establecimiento en territorio nacional de oficinas de representación de entidades financieras del exterior.

En materia de SNC, la SHCP contaba con las siguientes facultades:

- Expedir el reglamento orgánico de cada institución.

- Autorizar anualmente los programas operativos y financieros, sus presupuestos generales de gastos e inversiones.

- Las estimaciones de ingresos que se formularan.

\section{El Fondo de Apoyo Preventivo a las Instituciones de Banca Múltiple (Fonapre)}

El 10 de noviembre de 1986 se constituyó el Fondo de Apoyo Preventivo a las Instituciones de Banca Múltiple (Fonapre), cuyo sustento se encontraba en el artículo 77 de la entonces Ley del Servicio Público de Banca y Crédito publicada en el Diario Oficial de la Federación el 14 de enero de $1985 .^{5}$

Dicho precepto establecía que las instituciones de banca múltiple debían participar en el mecanismo de apoyo preventivo para preservar su estabilidad financiera; el gobierno federal sería fideicomitente, representado por la Secretaría de Programación y Presupuesto - ahora integrada a la SHCP - ; el Banco de México fungiría como fiduciario, y los bancos en el sistema como fideicomisarios.

La crisis financiera en la segunda mitad de la década de los ochenta permitió que algunas acciones que realizó el Fonapre solucionaran problemas de la banca, ya que el fondo otorgó, con

5 El gobierno federal, por conducto de la extinta Secretaría de Programación y Presupuesto, constituiría en el Banco de México, con fundamento en el artículo 77, fracción II, de la Ley del Servicio Público de Banca y Crédito, un fideicomiso cuya duración sería indefinida: "Fonapre". 
los recursos que contaba, créditos adicionales que sirvieron para la suscripción de certificados de aportación patrimonial (CAPS) a bancos con problemas de capitalización, préstamos a capital neto de los bancos para reactivar los activos improductivos, como carteras vencidas, y apoyos diferenciales para cartera de vivienda de interés social y otras formas de asistencia para indemnizaciones.

Sin embargo, los bancos que recibieron apoyo de Fonapre presentaban pérdidas de operación que se traducían en problemas coyunturales y estructurales, que analizaremos con posterioridad.

Con la reforma legal al sistema financiero en 1990, aunado a la iniciativa de reprivatización de la banca comercial, la denominación y atribuciones del fondo se cambiaron para quedar como Fondo Bancario de Protección al Ahorro (Fobaproa). ${ }^{6}$

\section{Banca pública burocrática, 1988-1990}

En este periodo se puede distinguir la banca nacionalizada hasta 1988, y la banca pública burocrática, de 1988 a 1990.

Esta etapa se caracteriza por la ineficacia de la administración pública para administrar las instituciones de crédito. La banca en este periodo se encontraba estática por la falta de recursos que agilizaran sus operaciones - estatización de la banca- y con ello su debilidad se acentuó, provocando que sus objetivos no culminaran en un desarrollo óptimo.

Para 1988 la supervisión de las autoridades del sistema bancario fue casi nula. El gobierno seguía estático, existía una aparente estabilidad económica, cuando en realidad existió un sobreendeudamiento público y privado, las tasas de interés simulaban estabilidad y todos los sectores empezaron a obtener créditos del sistema bancario.

Derivado del sobreendeudamiento, el gobierno tomó la decisión de vender los bancos o reprivatizarlos.

6 Véase infra, capítulos tercero y quinto. 


\section{Banca reprivatizada, 1990}

Mediante iniciativa del Poder Ejecutivo se derogó el quinto párrafo del artículo 28 constitucional, asimismo, se reformó y adicionó el inciso a, punto 22, del artículo 123 constitucional, con objeto de restablecer el régimen mixto de la prestación del servicio bancario, debido a que en los términos de los artículos tercero, cuarto y quinto transitorios de la Ley de Instituciones de Crédito (LIC) de 1990, todavía no dejaba de surtir efectos la Ley Reglamentaria del Servicio Público de Banca y Crédito (LRSPBC) de $1985 .^{7}$

En lo conducente a determinados casos, el Estado tenía la necesidad de concentrar sus acciones en el cumplimiento de sus objetivos, los cuales se traducían en:

- Satisfacer necesidades sociales y elevar el nivel de vida de la población.

- Ampliar y mejorar la calidad de servicios bancarios y crediticios evitando abusos, privilegios y subsidios.

- Establecer una limitación consistente en que el sector público ya no intervendría en la banca.

Como consecuencia de esas necesidades urgentes, el 18 de julio de 1990 surgen dos leyes fundamentales para el sistema financiero mexicano:

1) La Ley de Agrupaciones Financieras, y

2) La Ley de Instituciones de Crédito.

Dicha expedición de cuerpos normativos trajo como consecuencia que, al reprivatizarse la banca, se diera origen a los gru-

7 Quintana Adriano, Elvia Arcelia, Aspectos legales y económicos del rescate bancario en México, México, UNAM, Instituto de Investigaciones Jurídicas, 2002, pp. 31 y 32 . 
pos financieros y a la propiedad de los accionistas de las casas de bolsa.

La Ley de Instituciones de Crédito (LIC) de 1990, en términos del artículo 28 de la Constitución Política de los Estados Unidos Mexicanos, contemplaba los objetivos de la ley anterior, con sus respectivos ajustes acordes a la dinámica social y a la realidad económica del país.

A partir de 1995, con la fuerte crisis financiera, se aceleró el proceso de extranjerización de la banca, ya que los bancos extranjeros adquirieron a los bancos nacionales, quitándole a los mexicanos el control sobre el sistema financiero.

\section{CONCEPTOS DEL SISTEMA FINANCIERO}

\section{Definición de sistema financiero}

Conjunto de instituciones, tanto públicas, sector gubernamental, así como privadas y sector empresarial, a través de la cuales se llevan a cabo y se regulan las actividades en las operaciones de otorgamiento y obtención de créditos, la realización de inversiones, prestación de diversos servicios bancarios, emisión y colocación de instrumentos bursátiles y todas aquellas relativas a la actividad financiera.

Sistema financiero es el conjunto de mercados e instituciones que permiten que una sociedad capte recursos desde las unidades económicas poseedoras de ahorro o unidades de gasto con superávit y se canalicen a las unidades económicas deficitarias. La función primaria que realiza el sistema financiero se circunscribe a poner en contacto a quienes desean prestar o invertir fondos con aquellos que quieren captar nuevos recursos. ${ }^{8}$

8 García Castillo, Tonatiuh, Enciclopedia jurídica mexicana, México, PorrúaUNAM, 2002, p. 446. 
Se trata de una realidad que ha ido apareciendo paulatinamente para conformar un sistema orgánico que permite estudiarse en forma sistematizada y científica, alrededor de los fenómenos de captación de recursos, ahorro y su inversión en actividades de consumo o de producción, colocación. ${ }^{9}$

El sistema financiero mexicano está constituido por un conjunto de instituciones que captan, administran y canalizan a la inversión, el ahorro tanto de nacionales como de extranjeros, y se integra por: grupos financieros, banca comercial, banca de desarrollo, casas de bolsa, sociedades de inversión, aseguradoras, arrendadoras financieras, afianzadoras, almacenes generales de depósito, uniones de crédito, casas de cambio y empresas de factoraje. ${ }^{10}$

El sistema financiero mexicano es el conjunto de personas y organizaciones, tanto públicas como privadas, por medio de las cuales se captan, administran, regulan y dirigen los recursos financieros que se negocian entre los diversos agentes económicos, dentro del marco de la legislación correspondiente.

Es necesario fortalecer el marco jurídico del sistema financiero para incrementar su contribución a la economía, aumentar el monto de financiamiento en la economía, reducir el costo del crédito, promover la competencia efectiva en el sector e incentivar la entrada de nuevos participantes. Asimismo, se debe propiciar la estabilidad de dicho sistema a través de las sanas prácticas prudenciales, y promover que las autoridades del sector realicen una regulación efectiva y expedita del mismo. ${ }^{11}$

Los artículos 25, 26 y 28 de la Constitución Política de los Estados Unidos Mexicanos regulan la rectoría económica y el sistema financiero mexicano.

9 Meján Carrer, Luis Manuel Camp, Instituciones jurídicas del sistema financiero Mexicano, tesis doctoral, UNAM, 2007, p. 22.

10 Disponible en: http://wrwre.banxico.org.mx/divulgacion/glosario/glosario.html\#S.

11 Plan Nacional de Desarrollo 2013-2018. 


\section{Definición de finanzas}

Se definen como la administración científica de recursos, los recursos implican recursos humanos, materiales y financieros, estos últimos comprenden dinero, crédito y activos.

Es la disciplina que, mediante el auxilio de otras, tales como la contabilidad, el derecho y la economía, trata de optimizar el manejo de los recursos humanos y materiales de la empresa, de tal suerte que, sin comprometer su libre administración y desarrollo futuros, obstenga un beneficio máximo y equilibrado para los dueños o socios, los trabajadores y la sociedad. ${ }^{12}$

Rama de la economía; toma de esta los principios relativos a la asignación de recursos, pero se enfoca especialmente en los recursos financieros y se basa en la utilización de la información financiera que es producto de la contabilidad y en indicadores macroeconómicos como tasas de interés, tasa de inflación de crecimiento del producto interno bruto (PIB), etcétera; también, utiliza herramientas de la estadística y las matemáticas. ${ }^{13}$

\section{Definición de activos}

Los activos representan los bienes, derechos y otros recursos controlados económicamente por la empresa, de los que se espera obtener beneficios o rendimientos económicos en el futuro.

Dentro de la clasificación de activos se encuentran los siguientes:

Activos internacionales netos. Éstos se definen como la reserva bruta, más los créditos convenio con bancos centrales a más de seis meses, a lo que se restan los adeudos totales con el Fondo Monetario Internacional y con bancos centrales derivados de

12 Ortega Castro, Alfonso, Introducción a las finanzas, México, McGraw-Hill, 2002, p. 9.

13 Ochoa Setzer, Guadalupe, Administración financiera, México, McGrawHill, 2002, p. 15. 
convenios establecidos a menos de seis meses. Asimismo, se considera el resultado por el cambio de valor en términos de dólares de los Estados Unidos, de las operaciones de compraventa de divisas y oro concertadas a la fecha. ${ }^{14}$

Activos monetarios. Son aquellos activos que no pueden valer más que su valor nominal, por expresarse en moneda corriente y ser moneda corriente. ${ }^{15}$

Activos financieros. Es otra forma de denominar a los activos monetarios y son aquellos que se caracterizan por estar expresados y ser representativos de moneda corriente actual. Su monto se fija por su contrato u otra forma y originan a sus tenedores un aumento o una disminución en el poder de compra según tengan o no una redituabilidad por encima de la inflación. ${ }^{16}$

\section{Definición de crédito}

Crédito. Es aquel a través del cual una entidad financiera se obliga a poner a disposición del cliente una cantidad de dinero pactada en unas determinadas condiciones y en un cierto plazo. El cliente o acreditado podrá disponer o no de la cantidad estipulada en contrato según sus necesidades financieras. En todo caso, sólo tendrá que pagar intereses por el crédito dispuesto y no por el total disponible.

Préstamo de dinero que se pide a un banco o a una institución financiera. ${ }^{17}$

\section{Definición de dinero}

Cualquier activo o bien generalmente aceptado como medio de pago por los agentes económicos para sus intercambios y que

14 Disponible en: http://wrwre.banxico.org.mx/divulgacion/glosario/glosario.html\#S.

15 Cortina Ortega, Gonzalo, Prontuario bursátil y financiero, México, Trillas, 1988, p. 13.

16 Idem.

17 Condusef, Glosario para el docente y padre de familia. 
además cumpla las funciones de ser depósito de valor y unidad de cuenta.

Es el equivalente de todos los bienes y servicios de una colectividad. Por su aspecto externo puede ser moneda cuando es de metal, o billete cuando es de papel o polímero. Tiene cuatro funciones: como instrumento de cambio, como medida de valor, como instrumento de capitalización y de movilización de valor, y como instrumento de liberación de deudas y obligaciones. ${ }^{18}$

18 Banco de México, Glosario. 


\section{Capítulo Segundo}

\section{ESTRUCTURA DEL SISTEMA FINANGIERO MEXICANO}

\section{BANCO DE MÉXICO}

El banco central del país está encargado de la política monetaria. A partir de 1993 goza de autonomía. Sus funciones principales son regular la emisión y circulación de la moneda, los cambios, la intermediación y los servicios financieros, así como los sistemas de pago; operar con las instituciones de crédito como banco de reserva y prestar servicios de tesorería al gobierno federal.

Debe procurar la estabilidad del poder adquisitivo de la moneda y promover el sano desarrollo del sistema financiero preparando el buen funcionamiento de los sistemas de pagos. ${ }^{19}$

Se rige por la Ley del Banco de México y su Reglamento Interior y aplicarán supletoriamente a sus operaciones los siguientes ordenamientos: Ley de Instituciones de Crédito, la legislación mercantil, los usos bancarios y mercantiles y el Código Civil para el Distrito Federal, en Materia Común, y para toda la República en Materia Federa.

\section{Antecedentes}

Los antecedentes de esta institución se remontan al menos hasta principios del siglo XIX. En 1822, durante el reinado de Agustín de Iturbide, la historia registra la presentación de un pro-

19 Ley del Banco de México, artículo 2o. 
yecto para crear una institución con la facultad para emitir billetes que se denominaría "Gran Banco del Imperio Mexicano".

En el artículo 28 de la Constitución promulgada en 1917 se establecieron las características que debería tener el Banco Único de Emisión, y se determinó que la emisión de moneda se encargaría en exclusiva a un banco que estaría bajo el control del Gobierno.

El establecimiento del Banco de México no se hace realidad hasta el 1o. de septiembre de 1925, gracias a los esfuerzos presupuestarios y de organización del Secretario de Hacienda, Alberto J. Pani, y al apoyo recibido del Presidente Plutarco Elías Calles.

$\mathrm{El}$ acto fue presidido por el primer mandatario y al mismo concurrieron los personajes más sobresalientes de la época en la política, las finanzas y los negocios.

A la recién creada Institución se le entregó, en exclusiva, la facultad de crear moneda, tanto mediante la acuñación de piezas metálicas como a través de la emisión de billetes. Como consecuencia correlativa de lo anterior, se le encargó la regulación de la circulación monetaria, de los tipos de interés y del cambio sobre el exterior.

Durante las décadas recientes hemos sido testigos de importantes transformaciones institucionales y de trascendentales aportaciones del Banco Central a la economía del país.

La banca central, la política monetaria y los conocimientos teóricos y empíricos en que ésta se funda se encuentran sujetos a una evolución permanente. La fase de modernización definitiva del Banco de México se inicia con el otorgamiento de su autonomía, la cual empezó a regir a partir de abril de 1994.

En términos prácticos, la autonomía del Banco de México implica que ninguna autoridad pueda exigirle la concesión de crédito, con lo cual se garantiza el control ininterrumpido del instituto central sobre el monto del dinero (billetes y monedas) en circulación. La finalidad de la autonomía es que la operación del banco central sea conducente a la conservación del poder adquisitivo de la moneda nacional. Esto quiere decir que los precios de todas las cosas se mantengan estables a lo largo del tiempo. 
La autonomía del Banco Central puede verse como una barrera contra la ocurrencia de inflaciones futuras. La importancia de que exista este dique proviene de los múltiples males que causa la inflación, especialmente por lo que toca a la distribución del ingreso y a las posibilidades de crecimiento económico. Su autonomía es un buen dique contra la inflación en la medida en que no está dirigida a paliar sus síntomas, sino a evitar sus causas. Ello, porque está encaminada a impedir un uso abusivo del crédito del instituto emisor, fuente principal del mal a que se alude.

Por todo lo anterior, el Banco de México goza al día de hoy de un bien ganado y merecido prestigio. Independientemente de sus facultades legales, nadie le disputa la rectoría de los sistemas financiero y monetario, y las funciones regulatorias que en materia monetaria le son propias. ${ }^{20}$

El país se relaciona a través del Banco de México con bancos centrales de otros países, con personas morales extranjeras que sean autoridad en materia financiera, así como el participar en el Fondo Monetario Internacional y en otros organismos de cooperación financiera internacional que agrupen a bancos centrales. ${ }^{21}$

\section{Naturaleza jurídica}

De acuerdo con la Ley del Banco de México, en el artículo 1o. establece que el banco central será persona de derecho público con carácter autónomo y se denominará Banco de México. En el ejercicio de sus funciones y en su administración se regirá por las disposiciones de esta ley, reglamentaria de los párrafos sexto y séptimo del artículo 28 de la Constitución Política de los Estados Unidos Mexicanos. Es un organismo constitucional autónomo. ${ }^{22}$

20 Véase: http://wrew.85aniversariobanxico.com/2010/09/historia-del-banco-demexico/.

21 Ley del Banco de México, artículo 3o.

22 Los órganos constitucionales autónomos son aquéllos creados inmediata y fundamentalmente en la Constitución, y que no se adscriben a los poderes 


\section{Facultades}

En el artículo 3o. de la Ley del Banco de México se establecen las siguientes funciones de la institución:

- Regular la emisión y circulación de la moneda, los cambios, la intermediación y los servicios financieros, así como los sistemas de pagos.

- Operar con las instituciones de crédito como banco de reserva y acreditante de última instancia.

- Prestar servicios de tesorería al gobierno federal y actuar como agente financiero del mismo.

- Fungir como asesor del gobierno federal en materia económica, y particularmente financiera.

- Participar en el Fondo Monetario Internacional y en otros organismos de cooperación financiera internacional o que agrupen a bancos centrales.

- Operar con los organismos anteriormente mencionados, con bancos centrales y con otras personas morales extranjeras que ejerzan funciones de autoridad en materia financiera.

El ejercicio de las funciones y la administración del Banco de México estarán encomendados, en el ámbito de sus respectivas competencias, a una Junta de Gobierno y a un gobernador. ${ }^{23}$

tradicionales del Estado. Actúan con independencia en sus decisiones y estructura orgánica, depositarios de funciones estatales que se busca desmonopolizar, especializar, agilizar, independizar, controlar y/o transparentar ante la sociedad, con la misma igualdad constitucional. Ugalde Valetín, Filiberto, "Órganos constitucionales autónomos", Revista del Instituto de la Fudicatura Federal, núm. 29, enero de 2010.

23 Ley del Banco de México, artículo 38. 


\section{A. Junta de Gobierno}

La Junta de Gobierno está integrada por cinco miembros, designados conforme a lo previsto en el párrafo séptimo del artículo 28 constitucional. De entre estos, el Ejecutivo Federal nombrará al gobernador del banco, quien presidirá a la Junta de Gobierno; los demás miembros se denominarán subgobernadores.

La Junta de Gobierno tendrá las facultades siguientes: ${ }^{24}$ determinar las características de los billetes, y proponer a la Secretaría de Hacienda y Crédito Público, las composiciones metálicas de las monedas conforme a la Ley Monetaria de los Estados Unidos Mexicanos; autorizar las órdenes de acuñación de moneda y de fabricación de billetes; resolver sobre la desmonetización de billetes y los procedimientos para la inutilización y destrucción de moneda; resolver sobre el otorgamiento de crédito del banco al gobierno federal; fijar las políticas y criterios conforme a los cuales el banco realice sus operaciones, así mismo, puede determinar las características de éstas y las que por su importancia deban someterse en cada caso a su previa aprobación; autorizar las emisiones de bonos de regulación monetaria y fijar las características de éstos; determinar las características de los valores a cargo del gobierno federal que el banco emita, así como las condiciones en que se coloquen esos títulos y demás valores; establecer las políticas legalmente establecidos por la LBM.

Asimismo, deberá aprobar las exposiciones e informes del banco y de los miembros de la Junta de Gobierno sobre las políticas y actividades de aquel; aprobar los estados financieros correspondientes a cada ejercicio, así como los estados de cuenta consolidados mensuales; expedir las normas y criterios generales a los que deberá sujetarse la elaboración y ejercicio del presupuesto de gasto corriente e inversión física del banco, así como aprobar dicho presupuesto y las modificaciones que corresponda efectuarle durante el ejercicio. La Junta de Gobierno deberá hacer lo anterior de conformidad con el criterio de que la evolución

24 Ibidem, artículo 46. 
del citado presupuesto guarde congruencia con la del Presupuesto de Egresos de la Federación.

Deberá expedir, con sujeción a los criterios de carácter general señalados en el artículo 134 constitucional, las normas conforme a las cuales el banco deba contratar las adquisiciones y enajenaciones de bienes muebles, los arrendamientos de todo tipo de bienes, la realización de obra inmobiliaria, así como los servicios de cualquier naturaleza; resolver sobre la adquisición y enajenación de acciones o partes sociales por el banco, de empresas que le presten servicios; autorizar la adquisición y enajenación de inmuebles; resolver sobre la constitución de las reservas.

También aprobará el Reglamento Interior del Banco, que deberá ser publicado en el Diario Oficial de la Federación; aprobar las condiciones generales de trabajo que deban observarse en las relaciones entre el banco y su personal, así como los tabuladores de sueldos, en el concepto de que las remuneraciones de los funcionarios y empleados del banco no deberán exceder de las que perciban los miembros de la Junta de Gobierno, excepto en los casos en que dadas las condiciones del mercado de trabajo de alguna especialidad, se requiera de mayor remuneración; nombrar y remover al secretario de la Junta de Gobierno, así como a su suplente, quienes deberán ser funcionarios del banco; nombrar y remover a los funcionarios que ocupen los tres primeros niveles jerárquicos del personal de la institución; aprobar las políticas para cancelar, total o parcialmente, adeudos a cargo de terceros y a favor del banco, cuando sea notoria la imposibilidad práctica de su cobro, o éste sea económicamente inconveniente para la institución, y; resolver sobre otros asuntos que el gobernador someta a su consideración.

\section{B. Gobernador}

Corresponde al gobernador del Banco de México $^{25}$ tener a su cargo la administración del banco, la representación legal de

25 Artículo 47 de la Ley del Banco de México. 
éste y el ejercicio de sus funciones, sin perjuicio de las atribuciones que la Ley del Banco de México confiere a la Junta de Gobierno; ejecutar los acuerdos de la Junta de Gobierno y de la Comisión de Cambios; someter a la consideración y, en su caso, aprobación de la Junta de Gobierno las exposiciones e informes del Banco; actuar con el carácter de apoderado y delegado fiduciario; ser el enlace entre el banco y la administración pública federal; ser el vocero del banco, y puede delegar esta facultad en los subgobernadores; constituir consejos regionales; acordar el establecimiento, cambio y clausura de sucursales; designar a los subgobernadores que deban desempeñar cargos o comisiones en representación del banco; designar y remover a los apoderados y delegados fiduciarios; nombrar y remover al personal del banco, considerando las excepciones legalmente señaladas. Fijar, conforme a los tabuladores aprobados por la Junta de Gobierno, los sueldos del personal y aprobar los programas que deban aplicarse para su capacitación y adiestramiento, y comparecer ante comisiones del Senado de la República cada año, durante el segundo periodo ordinario de sesiones, a rendir un informe del cumplimiento del mandato.

\section{Direcciones generales y direcciones}

Éstas se integran por: Dirección de Auditoría; Dirección General de Contraloría y Administración de Riesgos; Dirección General de Operaciones de Banca Central; Dirección General de Investigación Económica; Dirección General de Asuntos del Sistema Financiero; Dirección General de Estabilidad Financiera; Dirección General de Sistemas de Pagos y Servicios Corporativos; Dirección General de Tecnologías de la Información; Dirección General Jurídica; Dirección General de Relaciones Institucionales y la Dirección General de Emisión. Dirección de Administración de Emisión; Dirección de Administración de Riesgos; Dirección de Análisis de Riesgos del Sistema Financiero; Dirección de Análisis de Riesgos Macrofinancieros; Dirección 
de Análisis Macroeconómico; Dirección de Análisis sobre Precios, Economía Regional e Información Dirección de Apoyo a las Operaciones; Dirección de Asuntos Internacionales; Dirección de Comunicación; Dirección de Contabilidad, Planeación y Presupuesto; Dirección de Control Interno; Dirección de Coordinación de la Información; Dirección de Disposiciones de Banca Central; Dirección de Estabilidad Financiera; Dirección de Estudios Económicos; Dirección de Evaluación de Servicios Financieros; Dirección de Fábrica de Billetes; Dirección de Información del Sistema Financiero; Dirección de Intermediarios Financieros de Fomento; Dirección de Medición Económica; Dirección de Operaciones Internacionales; Dirección de Operaciones Nacionales Dirección de Programación y Distribución de Efectivos; Dirección de Recursos Humanos; Dirección de Recursos Materiales; Dirección de Regulación y Supervisión; Dirección de Seguridad; Dirección de Sistemas de Pagos; Dirección de Sistemas; Dirección de Vinculación Institucional; Dirección Jurídica; Unidad de Transparencia.

\section{Operaciones del Banco de México}

Las operaciones que el Banco de México podrá realizar son las que a continuación se mencionan:

Operar con valores; otorgar crédito al gobierno federal, a las instituciones de crédito, así como al organismo descentralizado denominado Instituto para la Protección al Ahorro Bancario; otorgar crédito a las personas a que se refiere la fracción VI del artículo 3o. de la Ley del Banco de México. Constituir depósitos en instituciones de crédito o depositarias de valores, del país o del extranjero; adquirir valores emitidos por organismos financieros internacionales o personas morales domiciliadas en el exterior, de los previstos en la fracción II del artículo 20, LBM; emitir bonos de regulación monetaria; recibir depósitos bancarios de dinero del gobierno federal, de entidades financieras del país y del exterior, de fideicomisos públicos de fomento económico y de 
los referidos en la fracción XI siguiente, de instituciones para el depósito de valores, así como de entidades de la administración pública federal cuando las leyes así lo dispongan; recibir depósitos bancarios de dinero de las personas a que se refiere la fracción VI del artículo 3o.; obtener créditos de las personas a que se refiere la fracción VI del artículo 3o. y de entidades financieras del exterior, exclusivamente con propósitos de regulación cambiaria; así como constituir cauciones en efectivo o con valores respecto de las operaciones financieras que celebre con dichos sujetos conforme a la ley, derivadas de la administración de la reserva de activos internacionales; efectuar operaciones con divisas, oro y plata, incluyendo reportos; actuar como fiduciario cuando por ley se le asigne esa encomienda, o bien tratándose de fideicomisos cuyos fines coadyuven al desempeño de sus funciones o de los que el propio banco constituya para cumplir obligaciones laborales a su cargo, y recibir depósitos de títulos o valores, en custodia o en administración, de las personas señaladas en las fracciones VII y VIII anteriores. También podrá recibir depósitos de otros efectos del gobierno federal.

Asimismo, el Banco de México podrá, en coordinación con las demás autoridades competentes, elaborar, compilar y publicar estadísticas económicas y financieras, así como operar sistemas de información basados en ellas y recabar los datos necesarios para esos efectos; llevar a cabo, directamente o a través de terceros, la comercialización de monedas conmemorativas, así como de los billetes y las monedas metálicas, que tengan empaque o acabado especial; utilizar los recursos de que disponga, en la fabricación de bienes para terceros y en la prestación de servicios a éstos, siempre que ello no afecte el adecuado desempeño de sus funciones, y adquirir o arrendar los bienes muebles y contratar los servicios y la obra inmobiliaria, necesarios o convenientes para su adecuada operación y funcionamiento, así como enajenar aquellos bienes muebles que dejaren de ser útiles para tales efectos. ${ }^{26}$

26 Artículo 62 de la Ley del Banco de México. 


\section{Obligaciones del Banco de México como órgano} constitucional autónomo

Cumplir con las obligaciones de transparencia y poner a disposición del público y mantener actualizada, en los respectivos medios electrónicos, de acuerdo con sus facultades, atribuciones, funciones u objeto social, según corresponda, la información, por lo menos, de los temas, documentos y políticas e información que dispone la Ley General de Transparencia y Acceso a la Información Pública en su título quinto. ${ }^{27}$

Poner a disposición del público y actualizar la siguiente información: ${ }^{28}$

1) La estadística de la emisión de billetes y acuñación de moneda metálica;

2) El informe del crédito que, en su caso, otorgue al gobierno federal de conformidad con la Ley del Banco de México;

3) El listado de las aportaciones realizadas por el banco de México a organismos financieros internacionales de conformidad con la Ley del Banco de México;

4) El listado de los financiamientos otorgados a las instituciones de crédito, en forma agregada;

5) El importe de la reserva de activos internacionales;

6) La relación de sanciones impuestas por infracciones a las disposiciones emitidas por el propio banco, que regulan las entidades y personas sujetas a su supervisión, excepto por aquellas relacionadas con operaciones realizadas como parte de política monetaria, para lo cual deberán señalar: a) el nombre, denominación o razón social del infractor; b) el precepto legal infringido, el tipo de sanción impuesta, el monto o plazo, según corresponda, así como la con-

27 Artículo 68 de la Ley Federal de Transparencia y Acceso a la Información Pública.

28 Artículo 72, fracción I, de la Ley Federal de Transparencia y Acceso a la Información Pública. 
ducta infractora, y c) el estado que guarda la resolución, indicando si se encuentra firme o bien, si es susceptible de ser impugnada y, en este último caso, si se ha interpuesto algún medio de defensa y su tipo, cuando se tenga conocimiento de tal circunstancia por haber sido debidamente notificada por autoridad competente.

En todo caso, si la sanción impuesta se deja sin efectos por alguna autoridad competente, deberá igualmente publicarse tal circunstancia, y

7) La exposición sobre la política monetaria a seguir por el propio banco, así como los informes trimestrales sobre la inflación, la evolución económica y el comportamiento de los indicadores económicos del país y la ejecución de la política monetaria y, en general, las actividades del banco, que éste deba enviar al Ejecutivo Federal y al Congreso de la Unión de conformidad con la Ley del Banco de México.

\section{Estructura}

\section{Guadro 2}

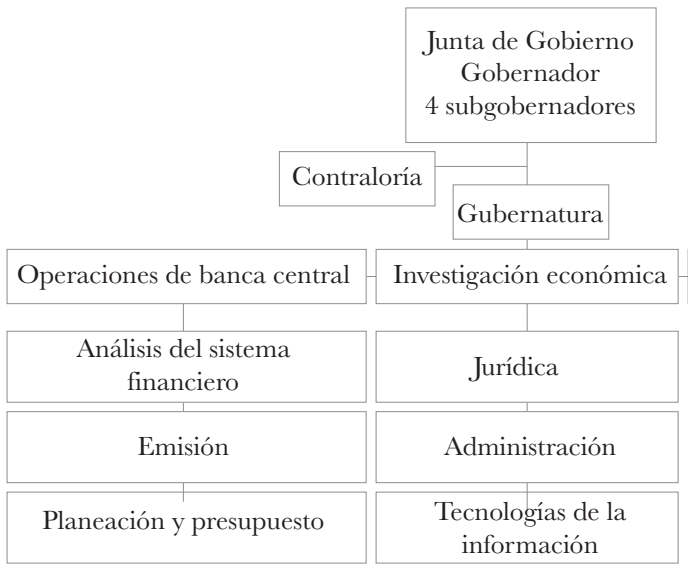

Fuente: Banco de México. 
Al desempeñar el Ejecutivo la actividad de fomentar el desarrollo nacional, se apoya en una dependencia de la administración pública federal: la Secretaría de Hacienda y Crédito Público.

\section{SEGRETARÍA DE HACIENDA y GRÉdito PÚblico}

Es la autoridad máxima del sistema financiero mexicano que ejerce sus funciones de supervisión y control por medio de la Subsecretaría de Hacienda y Crédito Público, así como de las tres comisiones nacionales: CNBV, GNSF y Consar.

\section{Naturaleza jurídica}

Es la dependencia de la administración pública centralizada cuya actividad está regulada en la Ley Orgánica de la Administración Pública Federal, es la encargada de apoyar al Ejecutivo Federal, presidente de la república, en la rectoría financiera del Estado entre sus facultades se encuentran: planear, coordinar, evaluar y vigilar el sistema bancario del país que comprende al banco central, a la Banca Nacional de Desarrollo y las demás instituciones encargadas de prestar el servicio de banca y crédito; asimismo tiene a su cargo el despacho de los asuntos que le encomiendan otras leyes, reglamentos, decretos, acuerdos y órdenes del presidente de la República. ${ }^{29}$

\section{Facultades}

De acuerdo con el Reglamento Interior de la Secretaría de Hacienda y Crédito Público, le corresponde al titular de esta Secretaría en materia financiera, llevar a cabo las siguientes tareas:

29 Ley Orgánica de la Administración Pública Federal, título segundo, capítulo II, artículo 31 . 
- Proponer al presidente de la República la política del gobierno federal en las materias financiera, fiscal, de gasto público, crediticia, bancaria, monetaria, de divisas y de precios y tarifas de bienes y servicios del sector público, para la formulación del Plan Nacional de Desarrollo y sus programas.

- Planear, coordinar, conocer la operación y evaluar el sistema bancario mexicano respecto de las instituciones de banca de desarrollo, de las instituciones de banca múltiple en las que el gobierno federal tenga el control por su participación accionaria, así como de las demás entidades del sector paraestatal que corresponda coordinar a la Secretaría.

- Expedir los reglamentos orgánicos de las instituciones de banca de desarrollo que rijan su organización y funcionamiento, así como los lineamientos a que se sujetarán las instituciones de banca múltiple en las que el gobierno federal tenga el control por su participación accionaria, en las materias de presupuestos, administración de sueldos y prestaciones, y las demás objeto de regulación.

- Otorgar y revocar autorizaciones para la constitución, organización, operación y funcionamiento, según sea el caso, de instituciones de banca múltiple, de casas de bolsa, de instituciones de seguros, de instituciones de fianzas, de organizaciones auxiliares del crédito, de sociedades financieras de objeto limitado, de sociedades de información crediticia, de sociedades mutualistas de seguros, de consorcios de instituciones de seguros y de fianzas, de casas de cambio, de bolsas de futuros y opciones y de cámaras de compensación, así como de las filiales de instituciones financieras del exterior que se puedan constituir bajo la legislación aplicable y de los demás participantes del mercado de valores, futuros y opciones cuando las leyes u otros ordenamientos jurídicos otorguen dicha facultad a la secretaría. 
- Otorgar y revocar concesiones para la operación de bolsas de valores, así como para la prestación del servicio público de operación de la Base de Datos Nacional SAR y de aquellos propios de instituciones para el depósito de valores y de contrapartes centrales, así como modificar o prorrogar dichas concesiones.

- Otorgar y revocar autorizaciones para la constitución y funcionamiento de grupos financieros.

- Designar al presidente de la Comisión Nacional Bancaria y de Valores, al de la Comisión Nacional de Seguros y Fianzas, al de la Comisión Nacional del Sistema de Ahorro para el Retiro y al de la Comisión Nacional para la Protección y Defensa de los Usuarios de Servicios Financieros.

También esta Secretaría conocerá las resoluciones y recomendaciones de sus Juntas de Gobierno, en los términos de las disposiciones legales correspondientes.

\section{Estructura}

\section{GuAdro 3}

\begin{tabular}{|c|c|c|c|c|c|}
\hline & & $\begin{array}{l}\text { Secretaría de } \\
\text { y Crédito }\end{array}$ & $\begin{array}{l}\text { Hacienda } \\
\text { ablico }\end{array}$ & & \\
\hline $\begin{array}{c}\text { Subsecretaría } \\
\text { de Hacienda } \\
\text { y Crédito } \\
\text { Público }\end{array}$ & $\begin{array}{c}\text { Subsecretaría } \\
\text { de Egresos }\end{array}$ & $\begin{array}{c}\text { Subsecretaría } \\
\text { de Ingresos }\end{array}$ & $\begin{array}{l}\text { Oficialía } \\
\text { Mayor }\end{array}$ & $\begin{array}{c}\text { Procuraduría } \\
\text { Fiscal de la } \\
\text { Federación }\end{array}$ & $\begin{array}{c}\text { Tesorería } \\
\text { Fiscal de la } \\
\text { Federación }\end{array}$ \\
\hline $\begin{array}{c}\text { Órgano } \\
\text { Interno de }\end{array}$ & $\begin{array}{c}\text { Órganos } \\
\text { desconcen- }\end{array}$ & Uni & $\begin{array}{l}\text { de Coorc } \\
\text { on Entida }\end{array}$ & $\begin{array}{l}\text { ación Hacend } \\
\text { Federativas }\end{array}$ & \\
\hline Control & trados & Unida & de Comun & ción Social y & cero \\
\hline & & Unidad & Enlace col & Congreso de & Unión \\
\hline
\end{tabular}

FuENTE: Secretaría de Gobernación. 
Funciona a través de tres subsecretarías que se mencionan a continuación.

La Subsecretaría de Hacienda y Crédito Público, que se integra con las siguientes unidades: Crédito Público; Planeación Económica de la Hacienda Pública; Banca de Desarrollo; Banca, Valores y Ahorro; Seguros, Pensiones y Seguridad Social, y Unidad de Asuntos Internacionales de Hacienda. Su función es programar, organizar, dirigir y evaluar las actividades de las unidades administrativas a ellos adscritas, conforme a los lineamientos que determine el secretario.

La Subsecretaría de Ingresos, la cual integra a la Unidad Política de Ingresos y la cual se itegra por la Unidad de Legislación Tributaria. Esta subsecretaría tiene la función de proponer, la política de ingresos incluyendo la política fiscal, la de precios y tarifas, la de comercio exterior, la aduanera, la de coordinación fiscal y la de estímulos fiscales para el desarrollo de la economía nacional, en congruencia con la política de la hacienda pública y la política económica y social del país, en coordinación con otras unidades administrativas competentes de la Secretaría y del Servicio de Administración Tributaria. Elaborar y presentar, para aprobación superior, los anteproyectos de iniciativas de leyes y proyectos de reglamentos en materias fiscal y aduanera de la Federación, así como los proyectos de reglas generales y otras disposiciones de carácter fiscal y aduanero.

Y finalmente la Subsecretaría de Egresos que se encuentra integrada por las unidades de: Inversiones; Política y Control Presupuestario; Contabilidad Gubernamental e Informes sobre Gestión Pública, y las siguientes direcciones generales: Programación y Presupuesto B; Programación y Presupuesto A, y la Jurídica de Egresos. La función de esta subsecretaría esprogramar, organizar, dirigir y evaluar las actividades de las unidades administrativas a ellos adscritas, conforme a los lineamientos que determine el secretario. Coordinar la formulación y determinar el gasto público federal, para elaborar el proyecto de presupuesto de egresos de la Federación para cada ejercicio fiscal. Definir y 
coordinar los procesos de formulación e integración de la cuenta de la Hacienda pública federal. En el ámbito del gasto correspondiente a desarrollo agropecuario, recursos naturales, comunicaciones, Hacienda, turismo, energía, desarrollo social, trabajo y economía. Ser el conducto único para la atención de todas las solicitudes y consultas que presenten las dependencias y entidades de la administración pública federal, en materia de programación, presupuesto, ejercicio, control y seguimiento del gasto público federal. Elaborar el anteproyecto de decreto de presupuesto de egresos de la Federación para cada ejercicio fiscal.

\section{FONDOS Y FIDEICOMISOS PÚBLICOS ${ }^{30}$}

Los fideicomisos públicos constituidos por el gobierno federal para el fomento económico que realizan actividades financieras cuyo objeto o finalidad principal sea la realización habitual y profesional de operaciones de crédito, incluyendo la asunción de obligaciones por cuenta de terceros, también forman parte del sistema bancario mexicano y son publicados anualmente por la Procuraduría Fiscal de la Federación en el Diario Oficial de la Federación. Los fideicomisos públicos, que son sujetos a la supervisión de la CNBV, son los siguientes:

- Fondo de Operación y Financiamiento Bancario de la Vivienda (Fovi).

- Fondo de Garantía y Fomento para la Agricultura, Ganadería y Avicultura (Fondo, integrante del Fira).

- Fondo Especial para Financiamientos Agropecuarios (FEFA, integrante del Fira).

- Fondo de Garantía y Fomento para las Actividades Pesqueras (Fopesca, integrante del Fira).

30 Diario Oficial de la Federación, 15 de agosto de 2014. 
- Fondo Especial de Asistencia Técnica y Garantía para Créditos Agropecuarios (FEGA, integrante del FIRA)

- Fideicomiso de Fomento Minero (FIFOMI)

\section{Organismos de Fomento}

Las entidades de fomento económico, la mayoría con personalidad jurídica y patrimonio propios (salvo el Fovissste), sujetas a la supervisión de la CNBV conforme a sus respectivas leyes, son:

- Financiera Nacional de Desarrollo Agropecuario, Rural, Forestal y Pesquero (FND).

- Instituto del Fondo Nacional de la Vivienda para los Trabajadores (Infonavit).

- Fondo de la Vivienda del Instituto de Seguridad y Servicios Sociales de los Trabajadores del Estado (Fovissste).

- Instituto del Fondo Nacional para el Consumo de los Trabajadores (Infonacot).

Los fideicomisos públicos son instrumentos jurídicos creados por la administración pública para cumplir con una finalidad lícita y determinada, a efecto de fomentar el desarrollo económico y social a través del manejo de recursos aportados por el gobierno y administrados por una institución fiduciaria. Asimismo, mediante la figura legal del fideicomiso se da seguimiento a diversos programas y proyectos estatales y federales.

El fideicomiso es un contrato por virtud del cual una persona física o moral denominada fideicomitente, transmite y destina determinado patrimonio (bienes o derechos) a una institución fiduciaria encomendándole la realización de fines determinados y lícitos en beneficio de una tercera persona o en su propio beneficio.

Las partes que intervienen en el contrato de fideicomiso son:

- Fideicomitente. Es la persona que destina bienes o derechos para constituir el fideicomiso. 
- Fideicomisario. Es la persona que recibe el beneficio derivado del fideicomiso, puede ser el mismo fideicomitente.

- Fiduciario. Institución con autorización para llevar a cabo operaciones fiduciarias y quien recibe los bienes del cliente (patrimonio) para realizar los fines lícitos determinados por el fideicomitente.

Un fideicomiso puede tener muchas finalidades, son tan diversas que pueden consistir, entre otras, en la inversión y reinversión de los recursos monetarios del cliente; realizar pagos con cargo a dicho fondo; en la administración de fondos a favor de trabajadores o empleados, para el pago de sus primas de antigüedad, pensiones, jubilaciones y fondos de ahorro, etcétera; depósitos condicionales; para el desarrollo inmobiliario; para la emisión de certificados bursátiles o de certificados de participación ordinarios; para el establecimiento de garantías, etcétera.

El fiduciario tiene las facultades del titular, pero únicamente para llevar a cabo los fines que contenga el contrato de fideicomiso, no puede disponer de ellos libremente ya que siempre están sujetos a los fines del fideicomiso.

\section{Instituto de Protecaión AL Ahorro BANCARIO (IPAB)}

\section{Ubicación y naturaleza jurídica}

El Instituto para la Protección al Ahorro Bancario (IPAB) es un organismo descentralizado de la administración pública federal, con personalidad jurídica y patrimonio propios, creado con fundamento en la Ley de Protección al Ahorro Bancario el 21 de mayo de 1999,31 inició sus operaciones en esta misma fecha, y

31 Ley de Protección al Ahorro Bancario, título cuarto; Ley de Instituciones de Crédito, título segundo, capítulo I, sección segunda. 
tiene como prioridad mantener la confianza y la estabilidad del sistema bancario, además de establecer los incentivos necesarios para que exista mayor disciplina en el mercado. ${ }^{32}$

\section{Objeto y facultades generales}

- Proporcionar a las instituciones, en beneficio de los intereses de las personas (que realicen cualquiera de las operaciones garantizadas, público ahorrador), un sistema para la protección del ahorro bancario que garantice el pago, a través de la asunción por parte del instituto, en forma subsidiaria y limitada, de las obligaciones establecidas en la presente ley, a cargo de dichas instituciones.

- Administrar, en términos de la LPAB, los programas de saneamiento financiero que formule y ejecute en beneficio de los ahorradores y usuarios de las instituciones y en salvaguarda del sistema nacional de pagos.

\section{Atribuciones del IPAB}

- Asumir y, en su caso, pagar en forma subsidiaria, las obligaciones que se encuentren garantizadas a cargo de las instituciones, con los límites y condiciones que se establecen en la LPAB.

- Recibir y aplicar, en su caso, los recursos que se autoricen en los correspondientes Presupuestos de Egresos de la Federación, para apoyar de manera subsidiaria el cumplimiento de las obligaciones que el propio Instituto asuma en los términos de la LPAB, así como para instrumentar y administrar programas de apoyo a ahorradores y deudores de la banca.

32 Quintana Adriano, Elvia Arcelia, Enciclopedia jurídica mexicana. Léxico derecho bancario, México, Porrúa-UNAM, 2004, p. 388. 
- Suscribir y adquirir acciones ordinarias, obligaciones subordinadas convertibles en acciones y demás títulos de crédito emitidos por las instituciones que apoye.

- Suscribir títulos de crédito, realizar operaciones de crédito, otorgar garantías, avales y asumir obligaciones, con motivo de apoyos preventivos y programas de saneamiento financiero, tanto en beneficio de las instituciones como en las sociedades en cuyo capital participe directa o indirectamente el IPAB.

- Participar en sociedades, celebrar contratos de asociación en participación o constituir fideicomisos, así como en general realizar las operaciones y contratos de carácter mercantil o civil que sean necesarias para el cumplimiento de su objeto.

- Adquirir de las instituciones a las que el instituto apoye conforme a la LPAB, bienes distintos a la fracción III, artículo 68 de la LPAB.

- Otorgar financiamiento a las instituciones, como parte de los programas de saneamiento, o cuando con él se contribuya a incrementar el valor de recuperación de los bienes, y no sea posible obtener financiamientos de fuentes alternas en mejores condiciones.

- Llevar a cabo la administración cautelar de las instituciones de banca múltiple.

- Fungir como liquidador o síndico de las instituciones de banca múltiple.

- Obtener financiamientos conforme a los límites y condiciones establecidos en el artículo 46 de la LPAB y exclusivamente para desarrollar con los recursos obtenidos, acciones de apoyo preventivo y saneamiento financiero de las instituciones.

- Participar en el capital social o patrimonio de sociedades relacionadas con las operaciones que el instituto pueda realizar para la consecución de su objeto, incluyendo los 
de empresas que le presten servicios complementarios o auxiliares.

- Participar en la administración de sociedades o empresas, en cuyo capital o patrimonio participe el instituto, directa o indirectamente.

- Realizar subastas, concursos y licitaciones para enajenar los bienes o darlos en administración.

- Contratar los servicios de personas físicas y morales, de apoyo y complementarias a las operaciones que realice el instituto.

- Coordinar y participar en procesos de fusión, escisión, transformación y liquidación de instituciones y sociedades o empresas en cuyo capital participe el Instituto.

- Defender sus derechos ante los tribunales o fuera de ellos y ejercitar las acciones judiciales o gestiones extrajudiciales que le competan, así como comprometerse en juicio arbitral.

- Comunicar a la Procuraduría Fiscal de la Federación las irregularidades que por razón de su competencia le corresponda conocer a ésta, y sean detectadas por personal al servicio del instituto con motivo del desarrollo de sus funciones.

- Denunciar o formular querella ante el Ministerio Público de los hechos que conozca con motivo del desarrollo de sus funciones, que puedan ser constitutivos de delito y desistirse u otorgar el perdón, previa autorización de la Junta de Gobierno, cuando proceda.

- Evaluar de manera permanente el desempeño que las instituciones de banca múltiple y los terceros especializados, en su caso, tengan con respecto a la recuperación, administración y enajenación de bienes, de conformidad con lo que establece la LPAB y la LIC. 
4. Operaciones que no garantizará el IPAB 33

- Las obligaciones a favor de entidades financieras, nacionales o extranjeras.

- Las obligaciones a favor de cualquier sociedad que forme parte del grupo financiero al cual, en su caso, pertenezca la institución.

- Los pasivos documentados en títulos negociables, así como los títulos emitidos al portador. Las obligaciones garantizadas, documentadas en títulos nominativos, quedarán cubiertas en términos del artículo 6o. de esta ley, siempre y cuando los títulos no hayan sido negociados.

- Las obligaciones o depósitos a favor de accionistas, miembros del consejo de administración y de funcionarios de los dos primeros niveles jerárquicos de la institución de que se trate, así como apoderados generales con facultades administrativas y gerentes generales.

- Las operaciones que no se hayan sujetado a las disposiciones legales, reglamentarias, administrativas, así como a las sanas prácticas y usos bancarios, en las que exista mala fe del titular y las relacionadas con actos u operaciones ilícitas que se ubiquen en los supuestos del artículo 400 Bis del Código Penal para el Distrito Federal en Materia de Fuero Común y para toda la República en Materia de Fuero Federal.

\section{El derecho de acceso a la información pública gubernamental, IPAB}

Para tutelar el ejercicio del derecho de acceso a la información pública gubernamental, el IPAB ajustándose a los lineamientos que apruebe su Junta de Gobierno, deberá hacer del conocimien-

33 Artículo 10 de la Ley de Protección al Ahorro Bancario. 
to del público en general, a través de su portal de internet, las sanciones que al efecto imponga por infracciones a la LPAB o a las disposiciones que emanen de ella, para lo cual deberá señalar:

El nombre o denominación del infractor; el precepto infringido, el tipo de sanción impuesta, monto o plazo, según corresponda y la conducta infractora, y el estado que guarda la resolución, indicando si se encuentra firme o bien, si es susceptible de ser impugnada y en este último caso si se ha interpuesto algún medio de defensa y su tipo, cuando se tenga conocimiento de tal circunstancia por haber sido debidamente notificada por autoridad competente.

En todo caso, si la sanción impuesta se deja sin efectos por alguna autoridad competente, deberá igualmente publicarse tal circunstancia. La información antes señalada no será considerada como reservada o confidencial. ${ }^{34}$

\section{Estructura}

El gobierno y administración del IPAB están a cargo de una Junta de Gobierno y un secretario ejecutivo, respectivamente, quienes serán apoyados por la estructura administrativa que la propia Junta de Gobierno determine.

La Junta de Gobierno estará integrada por siete vocales: el secretario de Hacienda y Crédito Público, el gobernador del Banco de México, el presidente de la Comisión y cuatro vocales designados por el Ejecutivo Federal y aprobados por las dos terceras partes de los miembros de la Cámara de Senadores y en sus recesos, por la misma proporción de integrantes de la Comisión Permanente del Congreso de la Unión.

Los tres primeros vocales señalados anteriormente designarán siendo suplentes.

34 Artículo 94 de la Ley de Protección al Ahorro Bancario. 


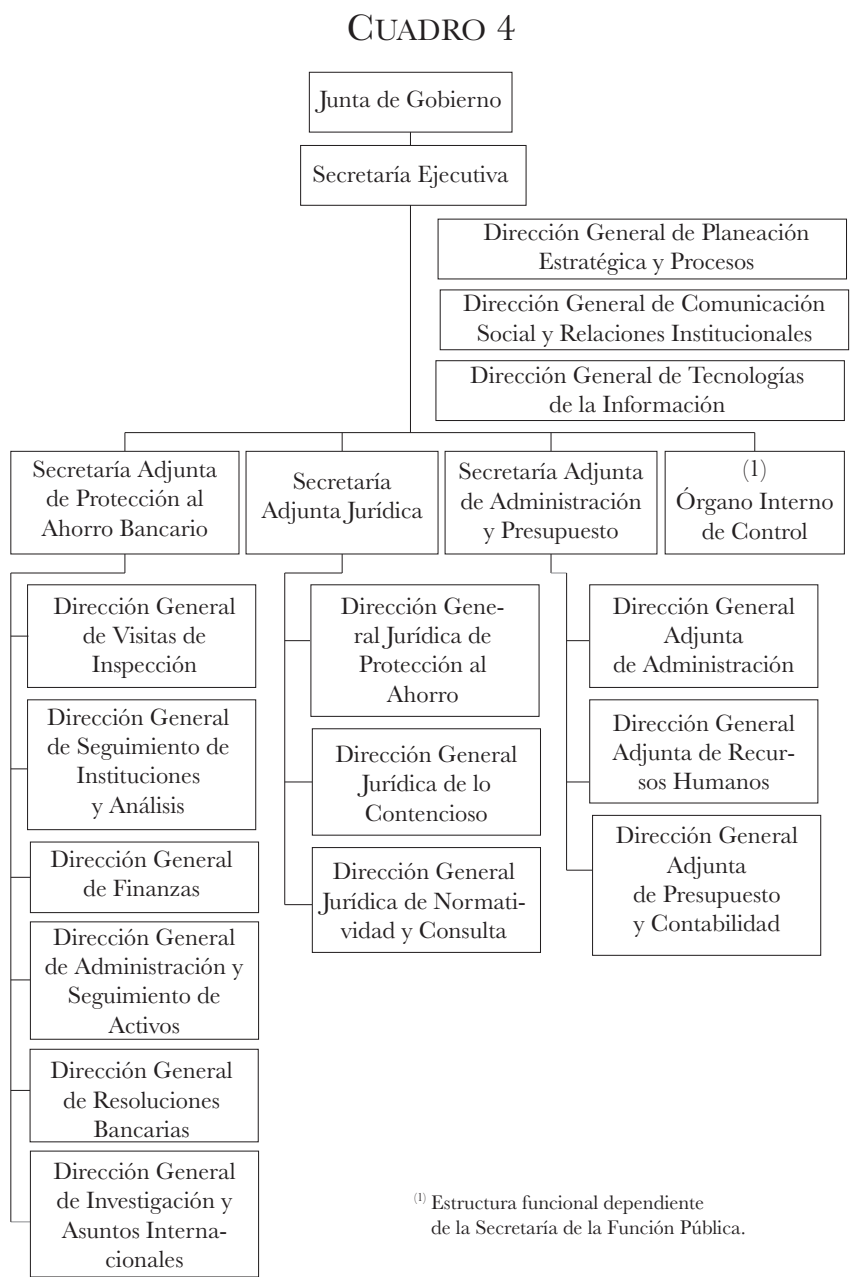

FUENTE: IPAB

\section{GOMisión NAGional PARA La Defensa y PROTEGaión DE LOS Usuarios de SERViGios FinANGIERos (CONDUSEF)}

Ante la necesidad de procurar equidad en las relaciones entre las instituciones financieras y sus usuarios, y con la ineción de otorgar 
a los segundos elementos para fortalecer la seguridad jurídica en las operaciones que realicen, surge la Comisión Nacional para la Protección y Defensa de los Usuarios de Servicios Financieros.

\section{Naturaleza jurídica}

Es un organismo público descentralizado, cuyo objeto es promover, asesorar, proteger y defender los derechos e intereses de las personas que utilizan o contratan un producto o servicio financiero ofrecido por las instituciones financieras que operan dentro del territorio nacional, así como también crear y fomentar entre los usuarios una cultura adecuada respecto de las operaciones y servicios financieros. ${ }^{35}$

La Comisión Nacional cuenta con plena autonomía técnica para dictar sus resoluciones y laudos, y facultades de autoridad para imponer las sanciones que su ley le señala.

\section{Objeto y facultades generales}

La Condusef tiene como finalidad promover, asesorar, proteger y defender los derechos e intereses de los usuarios frente a las instituciones financieras, arbitrar sus diferencias de manera imparcial y proveer a la equidad en las relaciones entre éstos, así como supervisar y regular de conformidad con lo previsto en las leyes relativas al sistema financiero, a las instituciones financieras, a fin de procurar la protección de los intereses de los Usuarios. ${ }^{36}$

Cabe destacar que la Ley de Protección y Defensa al Usuario de Servicios Financieros es de orden público, interés social y de observancia en toda la República. Los derechos que otorga esta Ley son irrenunciables. ${ }^{37}$

35 Ley de Protección y Defensa al Usuario de Servicios Financieros, artículos 4o., 5o. y 10, título segundo, capítulo I.

36 Idem.

37 Ibidem, artículo 30. 
Con base en la Ley de Protección y Defensa al Usuario de Servicios Financieros, la Condusef está facultada para:

- Atender y resolver consultas que presenten los usuarios, sobre asuntos de su competencia.

- Resolver las reclamaciones que formulen los usuarios.

- Llevar a cabo el procedimiento conciliatorio, ya sea en forma individual o colectiva, con las Instituciones Financieras.

- Actuar como árbitro en amigable composición y en estricto derecho.

- Proporcionar servicio de orientación jurídica y asesoría legal a los usuarios, en las controversias entre éstos y las instituciones financieras que se entablen ante los tribunales.

- Emitir recomendaciones a las autoridades federales y locales, así como a las instituciones financieras, tales que permitan alcanzar el cumplimiento del objeto de la Ley de Protección y Defensa al Usuario de Servicios Financieros y de la Condusef, así también para buscar el desarrollo sano del sistema financiero mexicano.

- Fomentar la cultura financiera, difundiendo entre los usuarios el conocimiento de los productos y servicios que representan la oferta de las instituciones financieras.

- Establecerá y mantendrá actualizado un Registro de Prestadores de Servicios Financieros.

- Establecerá y mantendrá actualizada una base de datos de comisiones que le sean reportadas y que comprenderá sólo las comisiones vigentes que efectivamente cobren, misma que se dará a conocer al público en general, por el medio de difusión que la Comisión Nacional considere pertinente.

- Establecerá y mantendrá actualizado, un registro de usuarios que no deseen que su información sea utilizada para fines mercadotécnicos o publicitarios. 
- Establecerá y mantendrá un Buró de Entidades Financieras, el cual se integrará con la información que aquella haya obtenido de las instituciones financieras y de los usuarios en el ejercicio de sus atribuciones, así como la que le proporcionen las autoridades competentes. Su organización y funcionamiento se sujetará a las disposiciones que al efecto expida la propia Comisión Nacional y tomará en consideración la experiencia internacional en materia de calificación de instituciones financieras, con especial énfasis en el riesgo para los Usuarios en la contratación de servicios financieros.

\section{Buró de entidades financieras}

La organización y funcionamiento del buró de entidades financieras se sujetará a las disposiciones que al efecto expida la Condusef, dicho buró se integrará con la información que la Comisión haya obtenido de las instituciones financieras y de los Usuarios en el ejercicio de sus atribuciones, así como la que le proporcionen las autoridades competentes.

La información contenida en dicho buró se referirá a los productos que ofrecen las instituciones financieras, sus comisiones, sus prácticas, sus sanciones administrativas, sus reclamaciones, y otra información que resulte relevante para informar a los usuarios del desempeño en la prestación de sus servicios y contribuir así a la adecuada toma de decisiones de los usuarios de servicios financieros.

La Condusef al establecer el Buró de Entidades Financieras, tomará en consideración la experiencia internacional en materia de calificación de instituciones financieras, con especial énfasis en el riesgo para los usuarios en la contratación de servicios financieros.

La información del Buró de Entidades Financieras será pública, y la Condusef deberá difundirla en su portal de internet. 
Asimismo, la Condusef emitirá una publicación periódica con información relevante para la toma de decisiones de los usuarios de servicios financieros.

Las instituciones financieras deberán publicar a través de su portal de internet y en sus sucursales la información que sobre ellas conste en el Buró de Entidades Financieras, en los términos que establezca la Condusef mediante disposiciones de carácter general que al efecto emita.

\section{Los procedimientos que realiza la Condusef}

Los procesos que realiza la Condusef son los siguientes:

- Procedimiento de conciliación.

- Procedimiento de arbitraje en amigable composición y en estricto derecho.

\section{A. Procedimiento de conciliación}

Como requisitos para solicitar la defensa de los intereses afectados, el usuario deberá presentar una reclamación ante la Condusef son:

- Nombre y domicilio del reclamante o su representante.

- Tipo de reclamación acompañada de una relación breve y concisa de los hechos que motivan la reclamación.

- Nombre y domicilio del banco que denuncia.

- Documentación probatoria que ampare la contratación del servicio que origina la reclamación.

Se presentará en un término de dos años contados desde el momento en que surja el hecho (violación del banco) o negativa del banco a satisfacer las pretensiones del usuario. 
Se notificará al banco, lo cual lo hará la Condusef, dentro de los ocho días contados a partir de que haya recibido la reclamación.

La comisión citará a las dos partes a una junta de conciliación (que podrá celebrarse vía telefónica o por otro medio idóneo); ésta se deberá realizar dentro de los veinte días, desde la recepción de la reclamación. Las dos partes tendrán sus respectivas sanciones en caso de no asistir.

La institución financiera deberá rendir un informe por escrito de todos los hechos que se le reclaman, que presentará antes o en la misma junta de conciliación, si no lo hace, será sancionada.

Ya en la junta, el conciliador va a insistir a las partes para que arreglen sus diferencias de manera pacífica y justa; si lo lograse, el convenio se hará constar en un acta circunstanciada.

Si no se cumpliese ese convenio, la Condusef sancionará.

Es importante destacar que la Condusef está facultada para completar la información de las reclamaciones en beneficio del usuario.

\section{B. Procedimiento de arbitraje en amigable composición $y$ en estricto derecho}

En caso de que no haya conciliación, la Condusef los invitará para que voluntariamente se sometan al arbitraje.

En el convenio que fundamente el juicio arbitral en amigable composición, las partes facultarán a la Comisión Nacional para resolver en conciencia, a verdad sabida y buena fe guardada, la controversia planteada, y fijarán de común acuerdo y de manera específica las cuestiones que deberán ser objeto del arbitraje, estableciendo las etapas, formalidades, términos y plazos a que deberá sujetarse el arbitraje. 
Es necesario destacar que para todo lo no previsto en el procedimiento arbitral se aplicará supletoriamente el Código de Comercio.

En el convenio que fundamente el juicio arbitral de estricto derecho, las partes facultarán a la Condusef, a resolver la controversia planteada con estricto apego a las disposiciones legales aplicables, y determinarán las etapas, formalidades, términos y plazos a que se sujetará el arbitraje, con arreglo a lo dispuesto en el artículo 75 LPDUSEF. El proceso de arbitraje es el siguiente:

- La demanda se presentará dentro de los nueve días contados a partir del día siguiente de que se celebró el compromiso arbitral.

- La Condusef deberá notificar a la institución financiera, la cual deberá presentar su contestación (cinco días).

- Contestada la demanda, se abrirá un espacio para ofrecer y desahogar pruebas; cinco y diez días respectivamente.

- Alegatos ocho días comunes.

- La Condusef, después de valorar pruebas y alegatos, emitirá un laudo.

- Los bancos tendrán un plazo de quince días contados a partir de la notificación, para que cumplan la resolución, en caso de no ser así, serán multados.

- Existen tres medios de defensa en contra del laudo y las resoluciones: a) juicio de amparo, $b$ ) aclaración del laudo y c) recurso de revisión.

\section{Estructura}

La Comisión Nacional contará con una Junta de Gobierno, así como con un presidente, a quienes corresponderá su dirección y administración, en el ámbito de las facultades que la presente 
ley les confiere. La Junta estará integrada por un representante de la Secretaría, un representante del Banco de México, un representante de cada una de las comisiones nacionales, tres representantes del Consejo Consultivo Nacional y el presidente, quien asistirá con voz pero sin voto. Cada uno de los integrantes de la Junta contará con su respectivo suplente, quien deberá tener el nivel inmediato inferior. Será presidida por el representante de la Secretaría de Hacienda y Crédito Público.

La Junta designará a un secretario y un prosecretario, los cuales deberán ser servidores públicos de la Comisión Nacional y no podrán desempeñar funciones diferentes a las de su encargo, asimismo sesionará seis veces al año, pudiendo reunirse de manera extraordinaria cuando así se considere necesario, previa convocatoria que haga el secretario de la Junta a solicitud de cualquiera de sus miembros. Dichas sesiones se efectuarán con la asistencia de por lo menos cinco de los miembros de la Junta.

Las resoluciones en las sesiones de la Junta requerirán del voto aprobatorio de la mayoría de los presentes, teniendo voto de calidad en caso de empate el presidente de la Junta, o en su caso, quien presida la sesión.

La Condusef contará con delegaciones regionales o, en su caso, estatales o locales, las cuales, como unidades administrativas desconcentradas del mismo, estarán jerárquicamente subordinadas a la administración central y tendrán las facultades específicas y la competencia territorial para resolver sobre la materia, de conformidad con lo que se determine en el Estatuto Orgánico. 


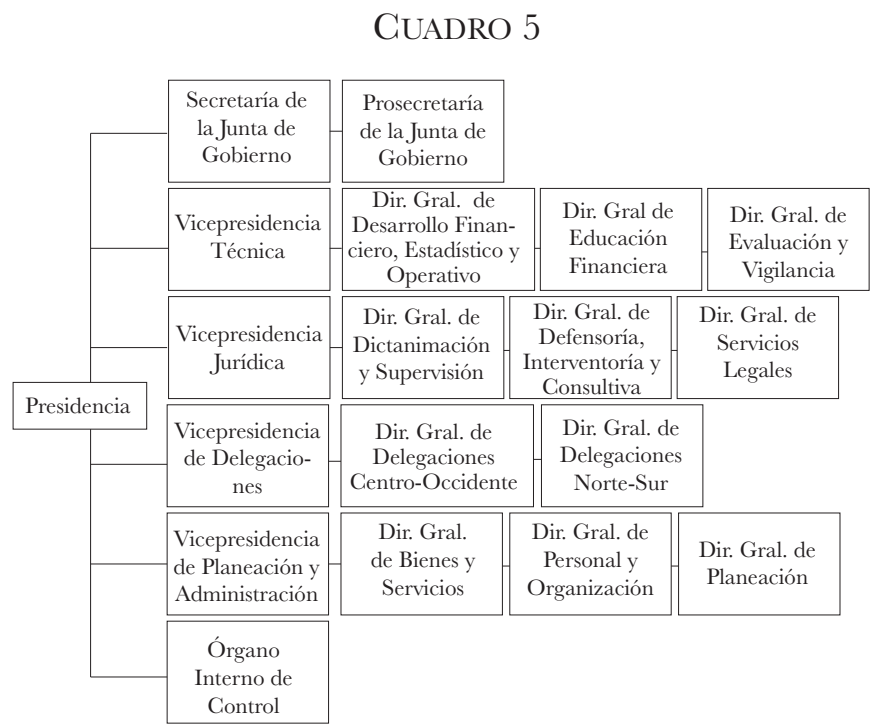

FUENTE: Condusef.

Finalmente se concluye que el país se organiza mediante un sistema financiero a través de la rectoría financiera del Estado. En dicho sistema se distinguen cuatro grandes campos:

1) El de las autoridades: a) Banco de México; $b$ ) Secretaría de Hacienda y Crédito Público (SHCP).

2) El de las comisiones de vigilancia al sistema, que se revisarán en el siguiente apartado: a) Comisión Nacional Bancaria y de Valores (CNVB); b) Comisión Nacional de Seguros y Fianzas (GNSF); c) Comisión Nacional de Sistemas de Ahorro para el Retiro (Consar).

3) El de los Organismos de Protección al Sistema: a) PAB: Instituto de Protección al Ahorro Bancario; b) Condusef: Comisión Nacional de Defensa a los Usuarios de Servicios Financieros.

4) El de las instituciones financieras, que de igual manera se estudiarán más adelante: sociedades controladoras de 
grupos financieros; instituciones de crédito; casas de bolsa; especialistas bursátiles; bolsas de valores; sociedades de inversión; sociedades operadoras de sociedades de inversión; sociedades distribuidoras de acciones de sociedades de inversión; almacenes generales de depósito; uniones de crédito; arrendadoras financieras; empresas de factoraje financiero; sociedades de ahorro y préstamo; casas de cambio; sociedades financieras de objeto limitado; instituciones para el depósito de valores; contrapartes centrales; instituciones calificadoras de valores; sociedades de información crediticia; personas que operen con el carácter de entidad de ahorro y crédito popular y, otras instituciones y fideicomisos públicos que realicen actividades financieras y respecto de los cuales la Comisión ejerza facultades de supervisión. 


\section{CAPÍTUlO TERCERO \\ COMISIONES DE VIGILANGIA}

\section{COMISIÓN NAGiONAL BANGARIA Y DE VALORES (CNBV)}

\section{Naturaleza jurídica}

Es un órgano desconcentrado de la Secretaría de Hacienda y Crédito Público que tiene autonomía técnica y facultades ejecutivas; es decir, es una institución autónoma para llevar a cabo las funciones establecidas en su ley, pero que no tiene patrimonio propio ni personalidad jurídica, sino que depende para el ejercicio de su presupuesto de la $\mathrm{SHCP}^{38}$

\section{Objeto}

Este organismo tiene como propósito supervisar y regular a las entidades financieras en el ámbito de su competencia. Su actividad está encaminada a procurar la estabilidad y el correcto funcionamiento del sistema financiero, así como mantener y fomentar el sano y equilibrado desarrollo de ese sistema en protección de los intereses del público. ${ }^{39}$ En materia financiera funge como órgano de consulta del gobierno federal.

El procedimiento de supervisión se hace por medio de visitas de inspección, verificación de operaciones y auditorías de regis-

38 Ley de la Comisión Nacional Bancaria y de Valores, título I, capítulo I.

39 Ley de la Comisión Nacional Bancaria y de Valores, artículo 2o. 
tros y sistemas, en las instalaciones o equipos automatizados de las entidades financieras, para comprobar el estado en que se encuentran estas últimas.

La supervisión se realiza por medio del análisis de la información económica y financiera, que están obligadas las entidades a enviar periódicamente a la Comisión a fin de medir posibles efectos de las mismas, y en el sistema financiero en su conjunto. La prevención y corrección se lleva a cabo mediante el establecimiento de programas de cumplimiento forzoso para las entidades financieras, tendientes a eliminar irregularidades; estos programas se establecen cuando las entidades presentan desequilibrios financieros que puedan afectar su liquidez, solvencia, estabilidad, pudiendo en todo caso instrumentarse mediante acuerdo con las propias entidades.

Ante el incumplimiento de los programas, la Comisión podrá proceder a intervenir administrativa o gerencialmente a la entidad con el objeto de suspender, normalizar o resolver las operaciones que pongan en peligro la solvencia, estabilidad o liquidez de la institución. ${ }^{40}$

\section{Funciones}

- Autorizar la constitución, operación, así como determinar el capital mínimo de las entidades; autorizar o aprobar los nombramientos de consejeros, directivos comisarios y apoderados de ellas en los términos de las leyes respectivas.

- Determinar o recomendar que se proceda a la amonestación, suspensión, veto o remoción, e inhabilitación de los mismos funcionarios y demás personas que puedan obligar a las entidades.

40 Quintana Adriano, Elvia Arcelia, Enciclopedia jurídica mexicana, cit., pp. 380382. 
- Ordenar la suspensión de operaciones de las entidades; intervenir administrativa o gerencialmente a las mismas con el objeto de suspender, normalizar o resolver las operaciones que pongan en peligro su solvencia, estabilidad o liquidez; igualmente puede hacerlo, e inclusive clausurar oficinas, negociaciones, empresas o establecimientos de personas físicas o morales que sin autorización realicen, actividades financieras.

- Imponer sanciones administrativas por infracciones a las leyes que regulan las actividades, entidades y personas sujetas a su supervisión; así como aplicar sanciones a los servidores públicos de instituciones financieras, de conformidad con las previsiones de la Ley Federal de Responsabilidades de los Servidores Públicos que correspondan a las contralorías internas.

- Elaborar y publicar estadísticas relativas a las entidades y mercados financieros;

- Investigar presuntas infracciones de uso indebido de información privilegiada con base en las leyes que rigen a las entidades.

- Expedir normas de registro de operaciones y las relativas a la información que deberán proporcionarle las entidades. Establecer criterios acerca de actos y operaciones que se consideren contrarios a los usos mercantiles, bancarios y bursátiles o sanas prácticas de los mercados financieros.

- Dictar las medidas para que las entidades ajusten sus actividades y operaciones a las leyes que les sean aplicables, a las disposiciones de carácter general que de ella deriven y a los referidos usos y sanas prácticas.

- La supervisión evalúa los riesgos que puedan derivar de sus operaciones, sistemas de control y la calidad de su administración, ya que deben mantener una adecuada liquidez, que sean solventes y estables, que se ajusten a 
las disposiciones que las rigen, y a los usos y sanas prácticas de los mercados financieros.

- La inspección debe realizarla a través de visitas, verificación de operaciones y auditorías de registros y sistemas.

- La vigilancia debe realizarse por medio del análisis de la información económica y financiera con el fin de medir posibles efectos, tanto en la entidad financiera como en el sistema financiero en su conjunto.

- La prevención y corrección debe llevarse a cabo mediante el establecimiento de programas que tiendan a eliminar irregularidades, los cuales serán de cumplimiento forzoso para las entidades financieras, y se aplicarán cuando éstas presenten desequilibrios financieros que afecten su liquidez, solvencia o estabilidad.

\section{Obligaciones}

La CNBV promueve la inclusión financiera a través de las siguientes aciones:

- Medir y generar estadísticas respecto a los productos y servicios financieros que existen a nivel nacional para identificar el grado de avance en el acceso y uso del sistema financiero formal.

- Desarrollar estudios y análisis, tanto a nivel nacional como internacional, a fin de mantener informada a la población en general sobre temas de inclusión financiera.

- Analizar la regulación para identificar posibles áreas de mejora y/o de oportunidad en materia de acceso a servicios financieros.

- Participar en foros y grupos de trabajo, a nivel nacional e internacional, donde se discutan temas de acceso a servicios financieros para intercambiar experiencias en temas de inclusión financiera. 


\section{Entidades supervisadas}

\section{A. Instituciones de crédito}

Son aquellas empresas constituidas bajo la forma de sociedades anónimas en su modalidad de actividad está dirigida a captar capitales ociosos, dándoles colocación útil, así como facilitar las operaciones de pago y las negociaciones con valores, acciones y obligaciones.

Se entiende por instituciones de crédito aquellas instituciones financieras que sólo podrán prestar el servicio de banca y crédito, ${ }^{41}$ entendiendo a éste como la captación de recursos del público $^{42}$ en el mercado nacional para su colocación en el público, mediante actos causantes de pasivo directo o contingente, quedando el intermediario obligado a cubrir el principal y, en su caso, los accesorios financieros de los recursos captados.

Las instituciones de crédito, por la conformación de su capital social se clasifican en nacionales, privadas y mixtas. A su vez dichas instituciones pueden ser: 1) instituciones de banca múltiple, 2) instituciones de banca de desarrollo.

\section{B. Sociedades financieras populares, sociedades financieras comunitarias y organismos de integración financiera rural}

Son entidades de micro finanzas, constituidas como sociedades anónimas de capital variable, que operan mediante la autorización de la $\mathrm{CNBV}$, conforme a la facultad que le confiere el artículo 9o. de la Ley de Ahorro y Crédito Popular (LACP).

Las sociedades financieras populares tienen como propósito el fomentar el ahorro popular y expandir el acceso al finan-

41 Artículo 2o. de la Ley de Instituciones de Crédito.

42 Se entenderá que existe captación de recursos del público cuando: a) se solicite, ofrezca o promueva la obtención de fondos o recursos de persona indeterminada o mediante medios masivos de comunicación, o b) se obtengan o soliciten fondos o recursos de forma habitual o profesional. 
ciamiento a aquellas personas que por su situación se han visto excluidas de los sistemas tradicionales de crédito, y en general, propiciar la solidaridad, la superación económica y social, y el bienestar de sus miembros y de las comunidades en que operan, sobre bases formativas y del esfuerzo individual y colectivo. ${ }^{43}$

Las sociedades financieras comunitarias y los organismos de integración financiera rural tienen como propósito promover la educación financiera rural, la cual tendrá por objeto propiciar el ahorro y el apoyo crediticio para el desarrollo de las actividades productivas del sector rural, para lo cual podrán recibir donativos y apoyos de los gobiernos federal, estatales y municipales.

Las sociedades financieras populares y sociedades financieras comunitarias, en su carácter de instituciones de microfinanzas, tienen por objeto proporcionar servicios financieros a los sectores y comunidades que carecen de ellos, diseñando servicios financieros ajustados a las características del mercado y al riesgo que presentan, para responder a la demanda de las poblaciones de escasos recursos excluidas del sector financiero.

\section{Operaciones}

- Recibir depósitos de dinero a la vista, de ahorro, a plazo, retirables en días preestablecidos y retirables con previo aviso.

- Recibir préstamos y créditos de instituciones de crédito nacionales o extranjeras, fideicomisos públicos, organismos e instituciones financieras internacionales, así como de instituciones financieras extranjeras.

- Otorgar préstamos o créditos a sus clientes.

- Descontar, dar en garantía o negociar títulos de crédito, y afectar los derechos provenientes de los contratos de financiamiento que realicen con sus clientes.

43 Comisión Nacional Bancaria y de Valores. 
- Distribuir seguros que se formalicen a través de contratos de adhesión, por cuenta de alguna institución de seguros o sociedad mutualista de seguros, debidamente autorizada.

- Distribuir fianzas, en términos de las disposiciones aplicables a dichas operaciones.

- Celebrar contratos de arrendamiento financiero.

- Realizar operaciones de factoraje financiero con sus clientes o por cuenta de éstos.

- Ofrecer el servicio de abono y descuento en nómina.

- Celebrar contratos de arrendamiento financiero con sus clientes.

- Prestar servicios de caja y tesorería.

- Expedir tarjetas de crédito.

- Ofrecer y distribuir entre sus socios las acciones de sociedades de inversión operadas por las sociedades operadoras de sociedades o por aquellas en cuyo capital participen indirectamente, así como promocionar la afiliación de trabajadores a las administradoras de fondos para el retiro en cuyo capital participen directa o indirectamente.

\section{Grupos financieros y sociedades controladoras}

Un grupo financiero es aquella agrupación integrada por la sociedad controladora y por entidades financieras, autorizada por la SHCP para su organización, constitución y funcionamiento. ${ }^{44}$

Los grupos financieros son las asociaciones de intermediarios de distinto tipo, con reconocimiento legal que se comprometen a seguir políticas comunes y a responder conjuntamente de sus pérdidas. Entre las ventajas que implican estos grupos destaca la posibilidad de que sus integrantes actúen de manera conjunta, ofreciendo servicios complementarios al público.

44 Ley para Regular las Agrupaciones Financieras, artículo 5o., fracción VII y artículo 11 . 
Los grupos financieros están compuestos por una sociedad controladora y por alguna de las sociedades financieras siguientes: almacenes generales de depósito, casas de cambio, instituciones de fianzas, instituciones de seguros, casas de bolsa, instituciones de banca múltiple, sociedades operadoras de fondos de inversión, distribuidoras de acciones de fondos de inversión, administradoras de fondos para el retiro, sociedades financieras de objeto múltiple y sociedades financieras populares.

El grupo financiero deberá formarse con cuando menos dos de las entidades financieras señaladas anteriormente. ${ }^{45}$

Las sociedades controladoras son sociedades anónimas que se constituyen para la adquisición y administración de las acciones de las entidades y de las empresas que componen el grupo financiero.

Las sociedades controladoras tendrán por objeto participar, directa o indirectamente, en el capital social de las entidades financieras integrantes del grupo financiero y establecer, a través de sus órganos sociales, las estrategias generales para la conducción del grupo financiero. ${ }^{46}$

\section{Casas de bolsa}

Sociedades autorizadas para realizar intermediación en el mercado bursátil. Se ocupan de las siguientes funciones: realizar operaciones de compraventa de valores; brindar asesoría a las empresas en la colocación de valores y a los inversionistas en la constitución de sus carteras; recibir fondos por concepto de operaciones con valores, y realizar transacciones con valores a través de los sistemas electrónicos de la BMV, por medio de sus operadores.

Entidad financiera privada autorizada para actuar en el mercado de valores. Su finalidad principal es la de auxiliar a inversio-

\footnotetext{
45 Ibidem, artículo 12.

46 Ibidem, artículo 23.
} 
nistas en la compra y venta de diversos títulos mercantiles tales como bonos, valores, acciones, etcétera. ${ }^{47}$

\section{E. Bolsa de valores}

Institución sede del mercado mexicano de valores. Institución responsable de proporcionar la infraestructura, la supervisión y los servicios necesarios para la realización de los procesos de emisión, colocación e intercambio de valores y títulos inscritos en el Registro Nacional de Valores (RNV), y de otros instrumentos financieros. Así mismo, hace pública la información bursátil, realiza el manejo administrativo de las operaciones y transmite la información respectiva a S.D. Indeval, supervisa las actividades de las empresas emisoras y casas de bolsa, en cuanto al estricto apego a las disposiciones aplicable, y fomenta la expansión y competitividad del mercado de valores mexicanos.

\section{F. Sociedades operadoras de fondos de inversión}

Son instituciones financieras autorizadas por la $\mathrm{CNBV}^{48}$ que se dedican de manera profesional a administrar las carteras de valores de los fondos de inversión y de terceros, con la finalidad de obtener rendimientos para los inversionistas.

Para organizarse y funcionar se requiere autorización de la misma Comisión, la que será intransmisible y sólo podrán gozar las sociedades anónimas organizadas de conformidad con la Ley General de Sociedades Mercantiles en todo lo no previsto en la Ley de Fondos de Inversión. La CNBV podrá autorizar la realización de actividades que sean conexas o complementarias a las que sean propias de su objeto, así como la prestación de servicios que auxilien a los intermediarios financieros en la celebración de sus operaciones mediante disposiciones de carácter general.

47 Disponible en: http://wrw. banxico.org.mx/divulgacion/glosario/glosario.html.

48 Ley de Fondos de Inversión, artículo 33. 


\section{G. Fondos de inversión}

Los fondos de inversión, anteriormente conocidas como sociedades de inversión, son la forma más accesible para que los pequeños y medianos inversionistas puedan beneficiarse del ahorro en instrumentos bursátiles. El inversionista compra acciones de estas sociedades cuyo rendimiento está determinado por la diferencia entre el precio de compra y el de venta de sus acciones. Los recursos aportados por los inversionistas son aplicados por los fondos a la compra de una canasta de instrumentos del mercado de valores, procurando la diversificación de riesgos.

Estas instituciones forman carteras de valores o portafolios de inversión con los recursos que captan del público inversionista. La selección de estos valores se basa en el criterio de diversificación de riesgos. $\mathrm{Al}$ adquirir las acciones representativas del capital de estas sociedades, el inversionista obtiene ventajas tales como la diversificación de sus inversiones, principio fundamental para disminuir el riesgo y, la posibilidad de participar del mercado de valores en condiciones favorables sin importar el monto de los recursos aportados.

Los lineamientos que debe considerar la institución para personas que quieran invertir en fondos de inversión son los siguientes:

1) Datos básicos. Documentos generales: nombre / estado civil / dependientes / banco.

2) Horizonte de inversión:

- Edad: menos de 40 / entre 41 y 50 / de 51 a 65 / de 66 a 75 / más de 75 .

- Cuando espera disponer de su inversión: inmediatamente, menos de 90 días, más de 90 días a un año, más de un año, no dispone de inversión.

- Porcentaje del que piensa disponer.

- Principal objetivo de sus inversiones: estudios, gastos médicos, comprar casas, tener patrimonio o para el retiro. 
- Qué se espera tener con el patrimonio:

a) Estabilidad por poco beneficio.

b) Estabilidad moderada y un beneficio arriba de la inflación.

c) Seguir el crecimiento de la bolsa.

3) Tolerancia al riesgo. Dispuesto al riego y a obtener mayor rendimiento por sus inversiones.

\section{H. Sociedades auxiliares del crédito}

Son aquellas instituciones de crédito que participan en la actividad financiera facilitando las operaciones de crédito y coadyuvando a un mejor funcionamiento del sistema financiero en general. Las organizaciones auxiliares de crédito de acuerdo con su capital se clasifican en: a) públicas: propiedad del Estado en $51 \%$, por lo menos; $b$ ) privadas: propiedad del sector privado en $100 \%$.

Por otra parte, las organizaciones auxiliares de crédito privadas se encuentran clasificadas de acuerdo con su actividad en:

a) Almacenes generales de depósito: los almacenes generales de depósito tendrán por objeto el almacenamiento, guarda o conservación, manejo, control, distribución o comercialización de bienes o mercancías bajo su custodia, incluyendo las que se encuentren en tránsito, amparados por certificados de depósito y el otorgamiento de financiamientos con garantía de los mismos. También podrán realizar procesos de incorporación de valor agregado, así como la transformación, reparación y ensamble de las mercancías depositadas a fin de aumentar su valor, sin variar esencialmente su naturaleza.

b) Uniones de crédito: son sociedades anónimas de capital variable, autorizadas discrecionalmente por la GNBV previo acuerdo de su Junta de Gobierno para servir a sus socios como medio de obtención y canalización de recur- 
sos financieros para recibir préstamos y satisfacer necesidades productivas de insumos de sus agremiados y hacer más eficientes sus procesos, organizativos y administrativos. Se rigen por la Ley de Uniones de Crédito. ${ }^{49}$

\section{Sofomes reguladas}

Las Sofomes son sociedades anónimas cuyo objeto social principal es el otorgamiento de crédito, así como la celebración de operaciones de arrendamiento financiero o factoraje financiero.

El artículo 87-B de la Ley General de Organizaciones y Actividades Auxiliares de Crédito (LGOAAC) las define como las sociedades anónimas que en sus estatutos sociales contemplen expresamente como objeto social principal la realización habitual y profesional de operaciones de otorgamiento de crédito, así como la celebración de operaciones de arrendamiento financiero o factoraje financiero, se considerarán como sociedades financieras de objeto múltiple. Las Sofomes pueden ser de dos tipos:

1) Sociedades financieras de objeto múltiple reguladas (Sofomes reguladas): con la reforma financiera publicada en el Diario Oficial de la Federación el 10 de enero de 2014, se incorporaron aquellas sociedades financieras que tienen vínculos patrimoniales con sociedades financieras populares, sociedades financieras comunitarias o sociedades cooperativas de ahorro y préstamo, en adición a aquellas que mantienen vínculos patrimoniales con instituciones de crédito. Además, se agregan a este régimen de entidades reguladas, las Sofomes que para fondear sus operaciones emitan valores de deuda inscritos en el Registro Nacional de Valores conforme a la Ley del Mercado de Valores.

49 Fuente Rodríguez, Jesús de la, Tratado de derecho bancario y bursátil, 6a. ed., México, Porrúa, 2010, t. II, p. 1147. 
Estas sociedades deben agregar a su denominación social la expresión "sociedad financiera de objeto múltiple" o su acrónimo "Sofom", seguido de las palabras "entidad regulada" o su abreviatura "E.R.", y están sujetas a la supervisión de la CNBV y por la Condusef en las atribuciones que la misma LGOAAC le confiere. ${ }^{50}$

2) Sociedades financieras de objeto múltiple no reguladas ( $S_{0-}$ fomes no reguladas): son aquellas que no se identifican como Sofomes "reguladas", y deben agregar a su denominación social la expresión "sociedad financiera de objeto múltiple" o su acrónimo "Sofom", seguido de las palabras "entidad no regulada" o su abreviatura "E.N.R.". Además están sujetas de la inspección y vigilancia de la CNBV, pero exclusivamente para verificar el cumplimiento de las disposiciones preventivas de lavado de dinero y financiamiento al terrorismo. ${ }^{51}$

Las Sofomes "no reguladas" deben proporcionar la información o documentación que les requieran en el ámbito de su competencia la Secretaría de Hacienda y Crédito Público (SHCP), el Banco de México, la Condusef y la CNBV, y pueden ser sancionadas en caso de no proporcionarla dentro de los plazos que tales autoridades señalen, o cuando la presenten de manera incorrecta.

\section{J. Indeval}

El Indeval es la institución privada que cuenta con autorización de acuerdo con la Ley, para operar como depósito central de valores, proporcionando los siguientes servicios:

50 Disponible en: http://wrew.cnbv.gob.mx/SECTORES-SUPERVISADOS/OTROS-SU PERVISADOS/Descripción-del-Sector/Paginas/SOFOMES-Reguladas.aspx.

51 Ley General de Organizaciones y Actividades Auxiliares del Crédito, artículo 95 bis. 
a) Custodia y administración de valores:

- Guarda física de los valores y/o su registro electrónico en instituciones autorizada para este fin.

- Depósito y retiro físico de documentos de las bóvedas de la institución.

- Ejercicios de derechos en efectivo, en especie y mixtos.

b) Operación nacional:

- Transferencia electrónica de valores.

- Transferencia electrónica de efectivo.

- Compensación de operaciones y liquidación DVP.

- Liquidación de operaciones (diversos plazos) para el mercado de dinero (directo y reporto) y mercado de capitales (operaciones pactadas en la Bolsa).

- Administración de colaterales.

c) Operación internacional:

- Liquidación de operaciones en mercados internacionales.

- Administración de derechos patrimoniales de emisiones extranjeras.

- Administración de impuestos sobre acciones estadounidenses.

d) Servicios de información:

- Asignación de códigos ISIN a emisiones.

- Servicios a emisoras.

K. Instituciones calificadoras de valores

Las instituciones calificadoras de valores son aquellas personas morales cuyo objeto social es exclusivamente la prestación 
habitual y profesional del servicio de estudio, análisis, opinión, evaluación y dictaminación sobre la calidad crediticia de valores.

Estas instituciones contribuyen a perfeccionar los mecanismos del mercado de valores y a consolidar la confianza de los inversionistas en el medio.

\section{Estructura de la CNBV}

\section{CUADRO 6}

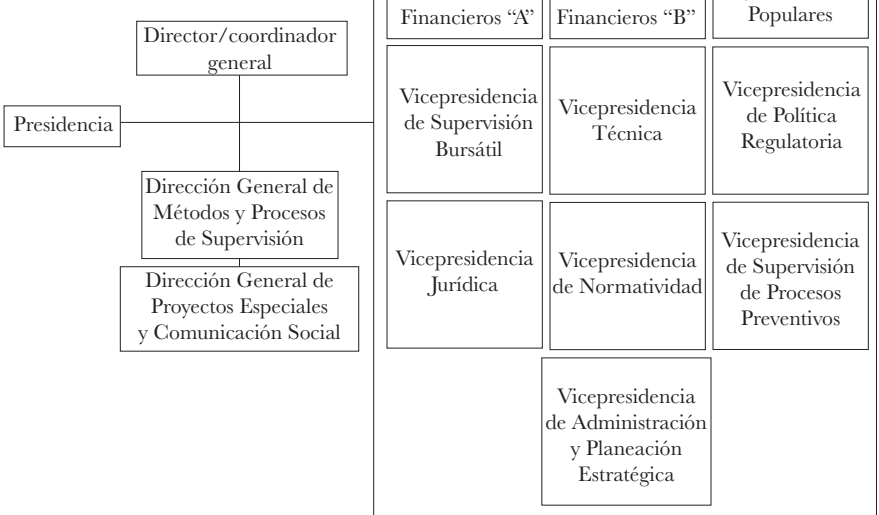

FUENTE: CNBV

\section{Comisión NaGional de SEguros y Fianzas (CNSF)}

Uno de los organismos de vigilancia con los que cuenta el sistema financiero mexicano para la regularización, supervisión y control para la canalización de los recursos económicos es la Comisión Nacional de Seguros y Fianzas. ${ }^{52}$

52 Disponible en: http://wrere.cnsf.gob.mx/CNSF/Paginas/somos.aspx. 


\section{Naturaleza jurídica}

Es un órgano desconcentrado de la Secretaría de Hacienda y Crédito Público, con autonomía técnica y facultades ejecutivas, contenidas en la Ley de Instituciones de Seguros y Fianzas. ${ }^{53}$

\section{Objeto}

Tiene como misión supervisar de manera eficiente que la operación de los sectores asegurador y afianzador se apegue al marco normativo, preservando la solvencia y estabilidad financiera de las instituciones, para garantizar los intereses al público usuario, así como promover el sano desarrollo de estos sectores con el propósitos de extender la cobertura de sus servicios a la mayor parte posible de la población, y su objetivo es facilitar el establecimiento de una efectiva coordinación entre las unidades administrativas y la visualización de su intervención en el esquema global de la comisión, para la consecución de los objetivos institucionales, así como orientar posteriores esfuerzos de análisis, diseño, instrumentación y evaluación parcial o total de adecuaciones que permitan conformar cada vez con mayor precisión la estructura funcional de la comisión.

\section{Funciones}

- Realizar la inspección y vigilancia de las instituciones y sociedades mutualistas, así como de las demás personas y entidades reguladas por la LISF y otras leyes relativas al sistema financiero.

- Otorgar, modificar o revocar las autorizaciones para organizarse, operar y funcionar como institución o sociedad mutualista, de acuerdo con la LISF.

53 El 13 de abril de 2013 se publicó en la Diario Oficial de la Federación el decrteto por el que se expide la Ley de Instituciones de Seguros y Fianzas. 
- Determinar el capital mínimo pagado que deberán cubrir las instituciones y sociedades mutualistas.

- Autorizar las solicitudes para la cesión de la cartera de las instituciones de seguros y sociedades mutualistas, o bien para la cesión de las obligaciones y derechos correspondientes al otorgamiento de fianzas de las instituciones.

- Autorizar las solicitudes para la fusión de instituciones y de sociedades mutualistas.

- Autorizar las solicitudes para la escisión de instituciones.

- Conocer y resolver sobre los recursos de revocación que se interpongan en contra de las sanciones administrativas aplicadas, así como sobre las solicitudes de condonación total o parcial de las multas impuestas.

- Recomendar al Ejecutivo Federal, a través de la SHCP, la remoción del director general de una institución nacional de seguros o de una institución nacional de fianzas.

- Declarar y levantar la intervención con carácter de gerencia de las instituciones o sociedades mutualistas.

- Emitir opinión a la SHCP en materia de los delitos previstos en la LISF.

- Intervenir en los procedimientos de liquidación, así como en las solicitudes de concurso mercantil, de las instituciones y sociedades mutualistas.

- Otorgar, modificar o revocar las autorizaciones a que se refiere esta ley, a las personas y entidades reguladas por la misma, distintas a las requeridas para organizarse y operar como instituciones y sociedades mutualistas.

- Vetar u ordenar que se dejen sin efecto las normas de autorregulación que expidan las organizaciones aseguradoras y afianzadoras, así como conocer y resolver sobre los recursos que se presenten en contra de estas determinaciones.

- Ordenar la suspensión, remoción, destitución o veto de los consejeros y directivos de las organizaciones aseguradoras y afianzadoras, de acuerdo con lo establecido en la 
LISF, así como conocer y resolver sobre los recursos que se presenten en contra de estas determinaciones.

- Investigar aquellos actos de personas físicas y de personas morales que no siendo instituciones o sociedades mutualistas hagan suponer la realización de operaciones violatorias a la LISF, pudiendo, al efecto, ordenar visitas de inspección a los presuntos responsables.

- Ordenar la suspensión de operaciones o la intervención administrativa, de negociaciones, empresas o establecimientos de personas físicas o a las personas morales que, sin la autorización correspondiente, realicen actividades que la requieran, o bien proceder a la clausura de sus oficinas.

- Fungir como órgano de consulta de la SHCP tratándose de los regímenes asegurador y afianzador, así como en los demás casos que las leyes determinen.

- Celebrar acuerdos de intercambio de información y convenios con organismos nacionales e internacionales con funciones de supervisión y regulación similares a las de la comisión, así como participar en foros de consulta y organismos de supervisión y regulación financieras a nivel nacional e internacional.

\section{Obligaciones}

- Emitir las disposiciones de carácter general necesarias para el ejercicio de las facultades que la LISF y demás leyes y reglamentos le otorgan, y para el eficaz cumplimiento de las mismas y de las disposiciones que con base en ellas se expidan.

- Emitir, en el ámbito de su competencia, las disposiciones y normas prudenciales de carácter general orientadas a preservar la solvencia, liquidez y estabilidad financiera de las instituciones y sociedades mutualistas. 
- Establecer los criterios de aplicación general en los sectores asegurador y afianzador acerca de los actos y operaciones que se consideren contrarios a los usos mercantiles, aseguradores y afianzadores, o sanas prácticas de dichos mercados financieros, y dictar las medidas necesarias para que las instituciones, sociedades mutualistas y demás personas y entidades sujetas a su inspección y vigilancia ajusten sus actividades y operaciones a las leyes y reglamentos que les sean aplicables, a las disposiciones de carácter general que de ellos deriven y a los referidos usos y sanas prácticas.

- Coadyuvar, mediante la expedición de disposiciones de carácter general a las instituciones y sociedades mutualistas, y a las demás personas y entidades sujetas a su inspección y vigilancia, con las políticas que en materia de seguros y fianzas competen a la SHCP.

- Participar, en los términos y condiciones que ésta y otras leyes señalen, en la elaboración de los reglamentos, disposiciones y disposiciones de carácter general a que las mismas se refieren.

- Dictar normas de registro de las operaciones de las instituciones y sociedades mutualistas, así como, en su caso, de otras personas y entidades reguladas por la LISF.

- Llevar el Registro General de Reaseguradoras Extranjeras.

- Adminisdtrar el registro de ajustadores de seguros.

- Llevar el registro de los auditores externos que dictaminen los estados financieros, así como el de los actuarios independientes que dictaminen sobre la situación y suficiencia de las reservas técnicas de las instituciones y sociedades mutualistas.

- Llevar el registro de productos de seguros, así como el registro de notas técnicas y documentación contractual de fianzas. 
- Determinar los días en que las instituciones y sociedades mutualistas deberán cerrar sus puertas y suspender sus operaciones.

- Ordenar la adopción de las medidas preventivas y correctivas de acuerdo a la LISF.

- Imponer sanciones administrativas por infracciones a ésta y a las demás leyes y reglamentos que regulan las actividades, instituciones, entidades y personas sujetas a su inspección y vigilancia, así como a las disposiciones que de ellos emanen.

- Amonestar, suspender, remover e inhabilitar, según corresponda, a los miembros del consejo de administración, comité de auditoría, directores generales, comisarios, directores, gerentes, delegados fiduciarios y funcionarios que puedan obligar con su firma a las instituciones y sociedades mutualistas, así como a los auditores externos que dictaminen los estados financieros y a los actuarios independientes que dictaminen sobre la situación y suficiencia de las reservas técnicas de las instituciones y sociedades mutualistas, en términos de lo previsto en esta ley, así como conocer y resolver sobre los recursos que se presenten en contra de tales determinaciones.

- Remover, suspender, destituir e inhabilitar a los servidores públicos que puedan obligar con su firma a una institución nacional de seguros o a una institución nacional de fianzas, y remover a los miembros de su comité de auditoría.

- Formular los presupuestos anuales de ingresos y egresos de la CNSF que se someterán a la autorización de la SHCP.

- Elaborar y publicar estadísticas y documentos relacionados con los sistemas asegurador y afianzador.

- Celebrar convenios de colaboración con la Condusef, que tengan por objeto establecer los mecanismos y canales a través de los cuales esta última hará del conocimiento de la CNSF, las observaciones que deriven del ejercicio de las 
facultades en materia de contratos de adhesión, publicidad y estados de cuenta previstas la LISF y en la Ley de Protección y Defensa al Usuario de Servicios Financieros.

- Proporcionar a las autoridades financieras del exterior toda clase de información necesaria para atender los requerimientos que le formulen en el ámbito de su competencia, tales como documentos, constancias, registros, declaraciones y demás evidencias que la Comisión tenga en su poder, o que pueda obtener en ejercicio de sus facultades o actuando en coordinación con otras entidades, personas o autoridades.

- Tratándose de intercambios de información protegida por disposiciones de confidencialidad, se deberá tener suscrito un acuerdo de intercambio de información con las autoridades financieras de que se trate, en el que se contemple el principio de reciprocidad. La Comisión podrá abstenerse de proporcionar la información solicitada o requerir la devolución de la información que haya entregado, cuando el uso que se le pretenda dar a la misma sea distinto a aquel para el cual haya sido solicitada, sea contrario al orden público, a la seguridad nacional o a los términos convenidos en el acuerdo de intercambio de información respectivo.

- Rendir un informe anual de sus labores a la SHCP.

\section{5. Ámbito de supervisión}

Empresas del sector de seguros y fianzas; de donde derivan las instituciones de seguros, instituciones de fianzas y las instituciones mutualistas de seguros.

- Afianzadoras.

- Reaseguradoras.

- Agentes de seguros y fianzas.

- Intermediarios de reaseguro. 
- Sociedades de servicios complementarios o auxiliares de las operaciones de seguros.

\section{A. Instituciones de seguros}

Están constituidas como sociedades anónimas de capital fijo, pudiendo ser privadas o nacionales y se dedican a una o más de las siguientes operaciones de seguro: vida, accidentes, enfermedades y daños en alguno(s) de los ramos siguientes: responsabilidad civil y riesgos profesionales; marítimos y transportes, incendio, agrícola, automóviles, crédito, diversos y especiales.

\section{B. Sociedades mutualistas de seguros}

Conjuntos de personas que actúan libre y voluntariamente para construir fondos de ayuda económica con aportaciones periódicas que se asignan a través de una colaboración espontánea, cuya finalidad es el auxilio de sus miembros en caso de necesidades presentes o futuras que provengan de enfermedades, accidentes u otros riesgos naturales. Estas sociedades eran reguladas por la Ley General de Instituciones y Sociedades Mutualistas de Seguros ${ }^{54}$ actualmente son reguladas por la Ley de Instituciones de Seguros y Fianzas. ${ }^{55}$

\section{Afianzadoras}

Sociedad autorizada por la Secretaría de Hacienda y Crédito Público, cuyo objeto consiste en otorgar fianzas a título oneroso.

54 Ley abrogada a partir del 4 de abril de 2015 por decreto publicado en el Diario Oficial de la Federación el 4 de abril de 2013.

55 Ley publicada en el Diario Oficial de la Federación el 4 de abril de 2013, última reforma publicada en el Diario Oficial de la Federación el 10 de enero de 2014. 
Una fianza es un contrato adquirido por dos partes por medio del cual una institución de fianzas debidamente autorizada por la Secretaría de Hacienda y Grédito Público, fiador, se compromete a cumplir una obligación de diversa índole con un acreedor, beneficiario, en caso de que el deudor, fiado, no lo haga, la garantía se logra mediante el cobro de una prima que este último debe pagar y que deberá avalarse. La fianza puede ser contratada por una persona física o moral.

Adquirir una fianza es sinónimo de certeza y precaución, facultades difíciles de adquirir en los tiempos actuales, es aquí donde radica la utilidad e importancia de la fianza; el hecho de adquirirla proporciona protección frente a un riesgo económico y obviamente la tranquilidad de que las obligaciones sean cumplidas, a pesar de que el deudor no pueda hacerlo.

\section{Reaseguradoras}

Se pueden definir a estas instituciones como "el seguro del seguro". Se trata de un contrato que suscribe una compañía de seguros con otra, en este caso, sería la reaseguradora, para que asuma parte o la totalidad del costo de un posible siniestro para responsabilizarse de riesgos muy elevados.

Por ello, el reaseguro otorga mayor estabilidad y solvencia al asegurador, que es quien, frente a sus asegurados, tiene la obligación de asumir el costo de las reclamaciones por siniestros cubiertos por la póliza.

\section{E. Agentes de seguros y fianzas}

Se consideran agentes de seguros a las personas físicas o morales que intervienen en la contratación de seguros mediante la comercialización, asesoramiento e intercambio de propuestas para conservar o modificar los seguros, según la mejor conveniencia de los contratantes. 
La intermediación de contratos de seguro que no tengan el carácter de contratos de adhesión está reservada exclusivamente a los agentes de seguros.

\section{F. Intermediarios de reaseguro}

Es la persona moral domiciliada en el país, autorizada conforme a la Ley de Instituciones de Seguros y Fianzas para intermediar en la realización de operaciones de reaseguro y de reafianzamiento. ${ }^{56}$

Las entidades legales constituidas como sociedades anónimas establecidas en el país, cuyo objetivo es la intermediación de los contratos de reaseguro y/o reafianzamiento, son consideradas como instituciones autorizadas de reaseguro. ${ }^{57}$

\section{G. Sociedades de servicios complementarios o auxiliares de las operaciones de seguro}

Son las sociedades autorizadas por la SHCP para prestar directa o indirectamente, servicios complementarios o auxiliares a los intermediarios financieros, para la realización de su objeto y administración.

\section{H. Filiales de instituciones financieras del exterior}

Las filiales se regirán por lo previsto en los tratados o acuerdos internacionales correspondientes, las disposiciones contenidas en la Ley de Instituciones de Seguros y Fianzas aplicables a las instituciones, y las disposiciones de carácter general para el establecimiento de filiales que al efecto expida la SHCP, oyendo la opinión de la GNSF.

56 Ley de Instituciones de Seguros y Fianzas, título primero, capítulo único, artículo 2o., fracción XX.

57 Disponible en: http://wrwre.cnsf.gob.mx/IntermedarioReaseguro/Paginas/Inter mediaroReasegurp.aspx. 
Las filiales podrán realizar las mismas operaciones que las instituciones, a menos que el tratado o acuerdo internacional aplicable establezca alguna restricción.

Respecto de las filiales, la Comisión tendrá todas las facultades que le atribuye la ley en relación con las instituciones. Cuando las autoridades supervisoras del país de origen de la institución financiera del exterior propietaria de acciones representativas del capital social de una filial o de una sociedad controladora filial, según sea el caso, deseen realizar visitas de inspección, deberán solicitarlo a la GNSF. A discreción de la misma, las visitas podrán hacerse por su conducto o sin que medie su participación.

\section{COMISIÓN NAGiONAL DEL Sistema de AHORRO PARA EL RETIRO (CONSAR)}

\section{Naturaleza jurídica}

La Comisión Nacional del Sistema de Ahorro para el Retiro (Consar) es un órgano desconcentrado de la SHCP y está regulada por la Ley del Sistema de Ahorro para el Retiro. ${ }^{58}$

\section{Objeto}

La Consar se encarga de regular, coordinar, supervisar y vigilar el sistema de ahorro para el retiro en nuestro país, el cual está conformado por cuentas individuales de los trabajadores, administradas por las administradoras de fondos para el retiro: Afores.

58 Ley de los Sistemas de Ahorro para el Retiro, capítulo II, sección I, artículo 5 o. 


\section{Funciones}

- Establecer reglas que regulan las funciones del sistema de ahorro para el retiro.

- Guidar los recursos de los trabajadores.

- Establecer sanciones y multas a las Afores que tengan incumplimientos.

- Vigilar que los recursos sean manejados en el régimen de inversión correspondiente.

\section{Obligaciones}

1) La Comisión Nacional Bancaria y de Valores, la Comisión Nacional de Seguros y Fianzas y la Comisión, de común acuerdo, establecerán las bases de colaboración para el ejercicio de sus funciones de supervisión.

2) Administrar y operar, en su caso, la Base de Datos Nacional SAR.

3) Imponer multas y sanciones, así como emitir opinión a la autoridad competente en materia de los delitos previstos en esta ley.

4) Actuar como órgano de consulta de las dependencias y entidades públicas, en todo lo relativo a los sistemas de ahorro para el retiro, con excepción de la materia fiscal.

5) Celebrar convenios de asistencia técnica.

\section{Instituciones de ahorro}

\section{A. Sociedades administradoras de fondos para el retiro (Afores)}

Las administradoras de fondos para el retiro, Afore, son instituciones financieras privadas de México, que administran fondos de retiro y ahorro de los trabajadores afiliados al Instituto Mexicano del Seguro Social y recientemente de los afiliados al Instituto de Seguridad y Servicios Sociales de los Trabajadores al Servicio 
del Estado. Fueron creadas por la Ley del Seguro Social de 1997 e iniciaron su operación el 1o. de julio del mismo año. Su funcionamiento está regulado por la Comisión Nacional del Sistema de Ahorro para el Retiro, Consar, y autorizado por la Secretaría de Hacienda y Crédito Público.

Su finalidad es que todos los trabajadores puedan contar con una pensión al momento de su retiro; cuando los recursos de la Afore no son suficientes para la pensión, el trabajador recibe una pensión garantizada del gobierno mexicano, equivalente a un salario mínimo de la Ciudad de México por día, y que se actualizará el mes de febrero todos los años conforme al INPC.

Cada trabajador asegurado tiene derecho a una cuenta individual en una Afore, cuando el trabajador no elige una Afore sus recursos van a una cuenta concentradora, tiempo después es asignado a una Afore, pero puede solicitar el traspaso de los recursos a la Afore de su preferencia una vez al año, los depósitos en esta cuenta son aportados por el trabajador, el patrón y el Estado, el aporte se realiza cada bimestre.

La cuenta se subdivide en:

- Retiro, cesantía en edad avanzada y vejez.

- Aportaciones voluntarias.

- Aportaciones complementarias.

- Vivienda, la Afore sólo informa al trabajador el saldo de la subcuenta, pero esos recursos los administra el Infonavit.

B. Sociedades de inversión especializadas para el manejo de fondos para el retiro (Siefores)

La Siefore es el instrumento mediante el cual la Afore invierte los recursos de la cuenta individual del trabajador para obtener mayores rendimientos.

El ahorro para el retiro estará depositado en la Siefore que corresponda conforme a la edad del trabajador: 
- Siefore 5: menores de 26 años.

- Siefore 4: entre 27 y 36 años.

- Siefore 3: entre 37 y 45 años.

- Siefore 2: entre 46 y 55 años.

- Siefore 1: mayores de 56 años. 


\section{PARTE ESPECIAL}

\section{LEGISLATIVA}




\section{ESTRUGTURA JURÍDICA QUE RIGE AL SISTEMA FINANGIERO MEXICANO. LEYES MARCO DEL SISTEMA FINANGIERO MEXICANO}

\section{Constitución Política de los Estados Unidos MEXICANOS, ARTÍCULOS QUE FUNDAMENTAN LA REGULACIÓN DE LAS FINANZAS}

La Constitución es la ley fundamental de un Estado en la cual se establecen los derechos y obligaciones de los ciudadanos y gobernantes. Es la norma jurídica suprema, y ninguna ley o precepto puede estar sobre ella. La Constitución es la expresión de la soberanía del pueblo y es obra del Congreso Constituyente.

Para facilitar el estudio de la materia de comercio inmersa en la Constitución que implica la ciencia del derecho mercantil desempeña un papel importante, no sólo con respecto al individuo en particular, sino además en el desarrollo económico, político y social de todos los países, a nivel interno, regional y mundial, debido a su intervención directa en la producción e intermediación de bienes y servicios necesarios para abastecer y satisfacer los grandes mercados que requiere la población dentro de los tres grandes niveles citados. ${ }^{59}$

Se puede catalogar, desde un punto de vista estrictamente jurídico, la ciencia del derecho mercantil como un orden jurídico que se aplica y perfecciona en cuatro grandes universos:

59 Quintana Adriano, Elvia Arcelia, Ciencia del derecho mercantil. Teoría, doctrina e instituciones, México, Porrúa, 2015, p. 99. 


\section{RELAGIONES MERCANTILES}

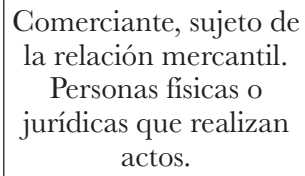

Cosas, bienes y servicios, batería de los actos de comercio y objetos de la relación mercantil (actividades).
Acto de comercio objeto de la relación mercantil.

Relaciones mercantiles

Los procedimientos judiciales o administrativos.

En la Constitución Política de los Estados Unidos Mexicanos se encuentran diversas disposiciones que se refieren a la regulación del sistema financiero mexicano, abarcando el denominado por la doctrina "capítulo económico", que comprende los artículos 25 al 28, entre otros, en los que se identifica la vinculación con la materia financiera:

Artículo 25. Le corresponde al Estado la rectoría del desarrollo nacional, la actividad económica del sector público, social y privado. El sector público tendrá a cargo las áreas estratégicas.

El Estado velará por la estabilidad de las finanzas públicas y del sistema financiero para coadyuvar a generar condiciones favorables para el crecimiento económico y el empleo...

Artículo 26. A. El Estado organizará un sistema de planeación democrática del desarrollo nacional que imprima solidez, dinamismo, competitividad, permanencia y equidad al crecimiento de la economía para la independencia y la democratización política, social y cultural de la nación.

Los fines del proyecto nacional contenidos en esta Constitución determinarán los objetivos de la planeación. La planeación será democrática y deliberativa. Mediante los mecanismos de participación que establezca la ley, recogerá las aspiraciones y demandas de la sociedad para incorporarlas al plan y los programas de desarrollo. Habrá un plan nacional de desarrollo al que se 
sujetarán obligatoriamente los programas de la Administración Pública Federal...

Artículo 27... Los bancos debidamente autorizados, conforme a las leyes de instituciones de crédito, podrán tener capitales impuestos, sobre propiedades urbanas y rústicas de acuerdo con las prescripciones de dichas leyes, pero no podrán tener en propiedad o en administración más bienes raíces que los enteramente necesarios para su objeto directo...

Artículo 28... El Estado tendrá un banco central que será autónomo en el ejercicio de sus funciones y en su administración. Su objetivo prioritario será procurar la estabilidad del poder adquisitivo de la moneda nacional, fortaleciendo con ello la rectoría del desarrollo nacional que corresponde al Estado. Ninguna autoridad podrá ordenar al banco conceder financiamiento. El Estado contará con un fideicomiso público denominado Fondo Mexicano del Petróleo para la Estabilización y el Desarrollo, cuya Institución Fiduciaria será el banco central y tendrá por objeto, en los términos que establezca la ley, recibir, administrar y distribuir los ingresos derivados de las asignaciones y contratos a que se refiere el párrafo séptimo del artículo 27 de esta Constitución, con excepción de los impuestos.

La conducción del banco estará a cargo de personas cuya designación será hecha por el Presidente de la República con la aprobación de la Cámara de Senadores o de la Comisión Permanente, en su caso; desempeñarán su encargo por períodos cuya duración y escalonamiento provean al ejercicio autónomo de sus funciones; sólo podrán ser removidas por causa grave y no podrán tener ningún otro empleo, cargo o comisión, con excepción de aquéllos que actúen en representación del banco y de los no remunerados en asociaciones docentes, científicas, culturales o de beneficiencia. Las personas encargadas de la conducción del banco central, podrán ser sujetos de juicio político conforme a lo dispuesto por el artículo 110 de esta Constitución...

Artículo 73. El Congreso tiene la facultad... X. Para legislar en toda la República sobre hidrocarburos, minería, sustancias químicas, explosivos, pirotecnia, industria cinematográfica, comercio, juegos con apuestas y sorteos, intermediación y servicios financieros... 
XVIII. Para establecer casas de moneda, fijar las condiciones que ésta deba tener, dictar reglas para determinar el valor relativo de la moneda extranjera y adoptar un sistema general de pesas y medidas;

XXIX. Para establecer contribuciones:

1o. Sobre el comercio exterior; $\ldots$

Artículo 3o. Sobre instituciones de crédito y sociedades de seguros;

XXIX-D. Para expedir leyes sobre planeación nacional del desarrollo económico y social, así como en materia de información estadística y geográfica de interés nacional;

XXIX-E. Para expedir leyes para la programación, promoción, concertación y ejecución de acciones de orden económico, especialmente las referentes al abasto y otras que tengan como fin la producción suficiente y oportuna de bienes y servicios, social y nacionalmente necesarios.

XXIX-F. Para expedir leyes tendientes a la promoción de la inversión mexicana, la regulación de la inversión extranjera, la transferencia de tecnología y la generación, difusión y aplicación de los conocimientos científicos y tecnológicos que requiere el desarrollo nacional.

XXIX-A. Para expedir la ley general que establezca los principios y bases en materia de mecanismos alternativos de solución de controversias, con excepción de la materia penal;

XXIX-N. Para expedir leyes en materia de constitución, organización, funcionamiento y extinción de las sociedades cooperativas. Estas leyes establecerán las bases para la concurrencia en materia de fomento y desarrollo sustentable de la actividad cooperativa de la Federación, entidades federativas, Municipios y, en su caso, demarcaciones territoriales de la Ciudad de México, en el ámbito de sus respectivas competencias;

XXIX-R. Para expedir las leyes generales que armonicen y homologuen la organización y el funcionamiento de los registros civiles, los registros públicos inmobiliarios y de personas morales de las entidades federativas y los catastros municipales;

Artículo 76. Son facultades exclusivas del Senado: 
I. Analizar la política exterior desarrollada por el Ejecutivo Federal con base en los informes anuales que el Presidente de la República y el Secretario del Despacho correspondiente rindan al Congreso.

Además, aprobar los tratados internacionales y convenciones diplomáticas que el Ejecutivo Federal suscriba, así como su decisión de terminar, denunciar, suspender, modificar, enmendar, retirar reservas y formular declaraciones interpretativas sobre los mismos;

Artículo 89. Las facultades otorgadas al Presidente de la República;

I. promover y ejecutar leyes que expida el Congreso de la Unión...

X. Dirigir la política exterior y celebrar tratados internacionales, así como terminar, denunciar, suspender, modificar, enmendar, retirar reservas y formular declaraciones interpretativas sobre los mismos, sometiéndolos a la aprobación del Senado. En la conducción de tal política, el titular del Poder Ejecutivo observará los siguientes principios normativos: la autodeterminación de los pueblos; la no intervención; la solución pacífica de controversias; la proscripción de la amenaza o el uso de la fuerza en las relaciones internacionales; la igualdad jurídica de los Estados; la cooperación internacional para el desarrollo; el respeto, la protección y promoción de los derechos humanos y la lucha por la paz y la seguridad internacionales.

XIII. Habilitar toda clase de puertos, establecer aduanas marítimas y fronterizas, y designar su ubicación.

Artículo 90. La Administración Pública Federal será centralizada y paraestatal conforme a la Ley Orgánica que expida el Congreso, que distribuirá los negocios del orden administrativo de la Federación que estarán a cargo de las Secretarías de Estado y definirá las bases generales de creación de las entidades paraestatales y la intervención del Ejecutivo Federal en su operación.

El Ejecutivo Federal representará a la federación en los asuntos en que ésta sea parte, por conducto de la dependencia que 
tenga a su cargo la función de consejero jurídico del gobierno o de las secretarías de Estado, en los términos que establezca la ley.

Siendo ésta, centralizada y paraestatal, en materia de comercio sea interior o exterior, contempla un doble aspecto:

a) Existe una interrelación del derecho administrativo y el mercantil en el momento mismo que muchos de los organismos y entidades en que se apoya para realizar su función, adoptan formas regidas por la LGSM.

b) Es el centro de donde emanan las disposiciones que proveen en la esfera administrativa a la exacta aplicación de las leyes en materia de comercio interior o exterior de México; actividad en la que concurren diversas secretarías por mencionar algunas como la Secretaría de Hacienda y Crédito Público; Secretaría de Economía; Secretaría de Relaciones Exteriores.

El artículo 103 menciona que los Tribunales de la Federación deberán resolver toda controversia que se suscite dentro de los tratados internacionales de los que el Estado Mexicano sea parte.

El artículo 104 establece que todas las controversias del orden civil o mercantil deberán ser conocidas por los tribunales de la federación, así como de los casos concernientes a miembros del cuerpo diplomático y consular. De todas las controversias del orden civil o mercantil que se susciten sobre el cumplimiento y aplicación de leyes federales o de los tratados internacionales celebrados por el Estado mexicano. A elección del actor y cuando sólo se afecten intereses particulares, podrán conocer de ellas, los jueces y tribunales del orden común. Las sentencias de primera instancia podrán ser apelables ante el superior inmediato del juez que conozca del asunto en primer grado y de todas las controversias que versen sobre derecho marítimo.

El artículo 131 establece que es facultad de la federación gravar las mercancías que se importen o exporten o que pasen de tránsito por el territorio nacional, así como reglamentar en todo 
tiempo y aun prohibir, por motivos de seguridad o de policía, la circulación de las mismas en el interior de la República. En este artículo se menciona que el Ejecutivo, facultado por el Congreso de la Unión, podrá aumentar, disminuir o suprimir las cuotas de las tarifas de exportación e importación, así como restringir y prohibir las importaciones, las exportaciones y el tránsito de productos, artículos y efectos, cuando lo estime urgente, a fin de regular el comercio exterior, la economía del país, la estabilidad de la producción nacional, o de realizar cualquiera otro propósito, en beneficio del país.

Finalmente el artículo 133 establece que

Esta Constitución, las leyes del Congreso de la Unión que emanen de ella y todos los tratados que estén de acuerdo con la misma, celebrados y que se celebren por el Presidente de la República, con aprobación del Senado, serán la Ley Suprema de toda la Unión. Los jueces de cada entidad federativa se arreglarán a dicha Constitución, leyes y tratados, a pesar de las disposiciones en contrario que pueda haber en las Constituciones o leyes de las entidades federativas.

El artículo 133 de la Constitución federal señala el orden jerárquico normativo de las leyes en nuestro país, reconociendo que en la Constitución Política de los Estados Unidos Mexicanos los tratados que estén de acuerdo con la Constitución y que se celebren por el presidente de la República con aprobación del senado y las leyes que emanen de ella, serán la ley suprema de toda la nación, el país, pareciendo que el legislador constituyente hubiera otorgado una supremacía con carácter ternario al orden legal mexicano, pero lo cierto es que la supremacía de la Constitución, como norma jurídica superior, da validez y unidad a nuestro orden jurídico nacional. Además, señala el mismo precepto legal que los jueces de cada Estado se arreglarán a dicha Constitución, leyes y tratados a pesar de las disposiciones en contrario que puedan haber en las Constituciones o leyes de las entidades federativas. 
Como un ejemplo de lo anterior en materia financiera el Tratado de Libre Ccomercio considera en su contenido, entre otros temas, lo relativo a servicios financieros.

\section{Ley del Banco de México y su Reglamento}

\section{A. Ley del Banco de México}

Surge en 1993 a iniciativa del Ejecutivo Federal y regula la estructura, funcionamiento y operaciones del Banco de México para encaminarlo a conseguir su objetivo trazado en la Constitución Política de los Estados Unidos Mexicanos: procurar la estabilidad del poder adquisitivo de la moneda nacional. También regular las operaciones activas, pasivas y de servicios realizadas por instituciones de crédito. Esta ley es reglamentaria de los párrafos sexto y séptimo del artículo 28 de la Constitución Política de los Estados Unidos Mexicanos.

Por la forma en la que se encuentra estructurada la ley, podemos encontrar: la naturaleza, las finalidades y las funciones del Banco de México; acerca de la emisión y circulación monetaria; de las operaciones que realiza el Banco; la expedición de normas; las disposiciones generales; de la reserva internacional y el régimen cambiario, así como del gobierno y la vigilancia.

\section{B. Reglamento Interior del Banco de México ${ }^{60}$}

Se encuentra estructurado mediante seis capítulos que abarcan la organización y competencia del Banco de México; estructura de la comisión de Responsabilidades y sus atribuciones; la contabi-

60 Reglamento Interior del Banco de México publicado en el Diario Oficial de la Federación el 30 de septiembre de 1994, vigente a partir del 1o. de octubre de 1994, abrogó el Reglamento Interior del Banco de México publicado en el Diario Oficial de la Federación el 4 de julio de 1985. 
lidad y estados financieros del Banco; recurso de reconsideración y del procedimiento administrativo de ejecución; recurso de revisión respecto de las sanciones que el Banco imponga de conformidad con la Ley para Regular las Sociedades de Información Crediticia y la Ley para la Transparencia y Ordenamiento de los Servicios Financieros; las diposiciones generales.

\section{Ley Monetaria de los Estados Unidos Mexicanos}

La presente ley establece que la unidad del sistema monetario de los Estados Unidos Mexicanos es el peso, las únicas monedas circulantes serán los billetes emitidos por el Banco de México con la denominación que fijen sus estatutos; y las monedas metálicas cuños y demás características que señalen los decretos relativos.

En esta ley se pueden encontrar: la descripción de la moneda y su régimen legal; emisión de la moneda; la reserva monetaria; la seguridad en la circulación monetaria y la desmonetización.

\section{Ley Orgánica de la Administración Pública Federal}

Ley que establece las bases de organización de la administración pública federal, centralizada y paraestatal.

\section{Administración pública federal}

De acuerdo con el artículo 90, la administración pública federal será centralizada y paraestatal conforme a la Ley Orgánica de la Administración Pública Federal, que expida el Congreso que establece las bases de organización a cargo de las secretarías de Estado.

La administración centralizada la conforman: Presidencia de la República; secretarías de Estado y Consejería Jurídica del Ejecutivo Federal. 
La administración paraestatal la conforman: organismos descentralizados; empresas de participación estatal; instituciones nacionales de crédito; organizaciones auxiliares de crédito; instituciones nacionales de seguros y fianzas y los fideicomisos.

En lo relativo a la materia financiera existen entre otras, tres secretarías de Estado que en el marco de sus atribuciones participan en el sistema financiero mexicano en lo relativo a instituciones de diversos sectores financieros de acuerdo con sus operaciones, ya sean de crédito o bursátiles, y que a continuación, se identifican.

A la Secretaría de Hacienda y Crédito Público, de conformidad con el artículo 31 de la LOAPF, le corresponde el despacho de los siguientes asuntos:

Planear, coordinar, evaluar y vigilar el sistema bancario del país que comprende al Banco Central, a la Banca Nacional de Desarrollo y las demás instituciones encargadas de prestar el servicio de banca y crédito.

Ejercer las atribuciones que le señalen las leyes en materia de seguros, fianzas, valores y de organizaciones y actividades auxiliares del crédito;

Organizar y dirigir los servicios aduanales y de inspección.

Secretaría de Economía, artículo 34 de la LOAPF. Cabe destacar que la importancia que representan las atribuciones de esta secretaría de Estado abarcan varios aspectos debido a que pueden estar inmersas en la actividad de las instituciones financieras ya sea desde que éstas se conforman, $i$. e. almacenes generales de depósito, por estar constitidas y registradas como sociedades anónimas; así como el papel que desempeñan éstas en el marco del ofrecimiento de los servicios financieros y apoyo, en el trayecto de actividades ya sea a través de operaciones o títulos de crédito, contratos y otros aspectos de trascendencia en el exterior respecto de mercancías y servicios. A esta secretaría le corresponde el despacho de los siguientes asuntos: 
Formular y conducir las políticas generales de industria, comercio exterior, interior, abasto y precios del país; con excepción de los precios de bienes y servicios de la Administración Pública Federal.

Regular, promover y vigilar la comercialización, distribución y consumo de los bienes y servicios.

Establecer la Política de industrialización, distribución y consumo de los productos agrícolas, ganaderos, forestales, minerales y pesqueros, en coordinación con las dependencias competentes

Fomentar, en coordinación con la Secretaría de Relaciones Exteriores, el comercio exterior del país.

Estudiar, proyectar y determinar los aranceles y fijar los precios oficiales, escuchando la opinión de la Secretaría de Hacienda y Crédito Público; estudiar y determinar las restricciones para los artículos de importación y exportación, y participar con la mencionada Secretaría en la fijación de los criterios generales para el establecimiento de los estímulos al comercio exterior.

Estudiar y determinar mediante reglas generales, conforme a los montos globales establecidos por la Secretaría de Hacienda y Crédito Público, los estímulos fiscales necesarios para el fomento industrial, el comercio interior y exterior y el abasto, incluyendo los subsidios sobre impuestos de importación, y administrar su aplicación, así como vigilar y evaluar sus resultados.

Normar y registrar la propiedad industrial y mercantil; así como regular y orientar la inversión extranjera y la transferencia de tecnología.

Autorizar el uso o modificación de denominación o razón social de sociedades mercantiles o civiles.

Establecer y vigilar las normas de calidad, pesas y medidas necesarias para la actividad comercial; así como las normas y especificaciones industriales.

Regular y vigilar, de conformidad con las disposiciones aplicables, la prestación del servicio registral mercantil a nivel federal, así como promover y apoyar el adecuado funcionamiento de los registros públicos locales.

Impulsar, en coordinación con las dependencias centrales o entidades del sector paraestatal que tengan relación con las actividades específicas de que se trate, la producción de aquellos bienes 
y servicios que se consideren fundamentales para la regulación de los precios.

Organizar y patrocinar exposiciones, ferias y congresos de carácter industrial y comercial.

Organizar la distribución y consumo a fin de evitar el acaparamiento y que las intermediaciones innecesarias o excesivas provoquen el encarecimiento de los productos y servicios.

Organizar la distribución y consumo a fin de evitar el acaparamiento y que las intermediaciones innecesarias o excesivas provoquen el encarecimiento de los productos y servicios.

Regular la producción industrial con exclusión de la que esté asignada a otras dependencias.

Asesorar a la iniciativa privada en el establecimiento de nuevas industrias en el de las empresas que se dediquen a la exportación de manufacturas nacionales.

Promover, orientar, fomentar y estimular el desarrollo de la industria pequeña y mediana y regular la organización de productores industriales.

Organizar, unificar e implementar el sistema informático que establecerá expedientes electrónicos empresariales con la finalidad de simplificar los trámites que los interesados realizan ante la administración pública federal centralizada y paraestatal.

Secretaría de Relaciones Exteriores, artículo 28 de la LOAPF. A esta secretaría corresponden las siguientes funciones:

Promover, propiciar y asegurar la coordinación de acciones en el exterior de las dependencias y entidades de la Administración Pública Federal; y sin afectar el ejercicio de las atribuciones que a cada una de ellas corresponda, conducir la política exterior, para lo cual intervendrá en toda clase de tratados, acuerdos y convenciones en los que el país sea parte...

\section{Código de Comercio}

El Código de Comercio es un instrumento jurídico que regula las actividades del comerciante, es decir, rige los actos de comercio en nuestro país, y en caso de no contemplar la regulación 
jurídica de un aspecto concreto, se deberá aplicar supletoriamente el Código Civil.

Dentro del Código de Comercio se encuentran regulados los siguientes aspectos: comerciantes; obligaciones comunes a todos los que profesan el comercio; registro el comercio, la contabilidad mercantil, correspondencia, actos de comercio, contratos mercantiles; comercio electrónico; comisión mercantil; factores y dependientes; depósito y préstamo mercantil; compraventa y permuta mercantiles, de la cesión de créditos comerciales y de la consignación mercantil, contrato mercantil de transporte terrestre, y juicios mercantiles dentro de lo que destacan el juicio ejecutivo mercantil oral ${ }^{61}$ y el arbitraje comercial.

\section{Código Civil Federal}

Es supletorio ${ }^{62}$ en la legislación mercantil y del Código de Comercio en materia federal, el cual contiene lo siguiente: "Disposiciones preliminares"; "De las personas"; "De los bienes"; "De las sucesiones" y "De las obligaciones.

61 La adición al libro quinto del título especial bis denominado "Del juicio ejecutivo mercantil oral", con los artículos 1390 ter al 1390 ter 15, publicada en el Diario Oficial de la Federación el 25 de enero de 2017, que entró en vigor el 25 de enero de 2018.

62 "SupletoriedAd DE LEYES. GuANDO SE APLICA. La supletoriedad sólo se aplica para integrar una omisión en la ley o para interpretar sus disposiciones en forma que se integre con principios generales contenidos en otras leyes. Cuando la referencia de una ley a otra es expresa, debe entenderse que la aplicación de la supletoria se hará en los supuestos no contemplados por la primera ley que la complementará ante posibles omisiones o para la interpretación de sus disposiciones. Por ello, la referencia a leyes supletorias es la determinación de las fuentes a las cuales una ley acudirá para deducir sus principios y subsanar sus omisiones. La supletoriedad expresa debe considerarse en los términos que la legislación lo establece. De esta manera, la supletoriedad en la legislación es una cuestión de aplicación para dar debida coherencia al sistema jurídico. El mecanismo de supletoriedad se observa generalmente de leyes de contenido especializados con relación a leyes de contenido general", 223069, tribunales colegiados de circuito, Semanario fudicial de la Federación, Octava Época, t. VII, mayo de 1991, p. 305. 


\section{Código Fiscal de la Federación}

El Código Fiscal de la Federación es un compendio de diversos aspectos fiscales, cuyo objetivo es determinar las contribuciones y las diversas obligaciones que se deben cumplir en relación con los impuestos federales; en términos legales, es el ordenamiento jurídico que define los conceptos fiscales fundamentales, fija los procedimientos para obtener los ingresos fiscales del gobierno, la forma de ejecución de las resoluciones fiscales, los recursos administrativos, así como los procedimientos y sistemas para resolver las controversias ante el Tribunal Fiscal de la Federación, entre otros aspectos.

El Código Fiscal de la Federación regula las contribuciones que la población mexicana debe aportar para apoyar al gasto de la Federación, los principales apartados de esta Ley son los siguientes: "Disposiciones generales", "De los derechos y obligaciones de los contribuyentes", "De las facultades de las autoridades fiscales", "De las infracciones y delitos fiscales", "De los procedimientos administrativos" y "Del juicio contencioso administrativo".

\section{Ley General de Sociedades Mercantiles}

Es la ley que se encarga de regular los tipos de sociedades mercantiles existentes en nuestro país, y se compone de los siguientes capítulos: "De la constitución y funcionamiento de las sociedades en general"; "De la sociedad en nombre colectivo"; "De la sociedad en comandita simple"; "De la sociedad de responsabilidad limitada"; "De la sociedad anónima"; "De la sociedad en comandita por acciones"; "De la sociedad cooperativa"; "De la sociedad por acciones simplificada"; "De las sociedades de capital variable"; "De la fusión, transformación, y escisión de las sociedades"; "De la disolución de las sociedades"; "De la liquidación de las sociedades"; "De las sociedades extranjeras"; "De la asociación en participación". 
La importancia de la aplicación de la LGSM en el sistema financiero mexicano radica en que diversas entidades financieras se constituyen como sociedades anónimas, ejemplo de ello entre muchos otros, es el que se encuentra en el artículo 8o. de la Ley General de Organizaciones y Actividades Auxiliares de Crédito, que establece: "Las sociedades que se autoricen para operar como organizaciones auxiliares del crédito y casas de cambio, deberán constituirse en forma de sociedad anónima, organizadas con arreglo a la Ley General de Sociedades Mercantiles..." .

Es relevante destacar que es la base obligada de referencia de lo que se conoce como derecho corporativo. ${ }^{63}$

\section{LEYES DE LAS COMISIONES DE VIGILANCIA AL SISTEMA}

\section{Ley de la Comisión Nacional Bancaria y de Valores y su Reglamento $(\mathrm{CNBV})^{64}$}

Se crea la Comisión Nacional Bancaria y de Valores como órgano desconcentrado de la Secretaría de Hacienda y Crédito Público, con autonomía técnica y facultades ejecutivas; tendrá por objeto supervisar y regular en el ámbito de su competencia a las entidades integrantes del sistema financiero mexicano, a fin de procurar su estabilidad y correcto funcionamiento, así como mantener y fomentar el sano y equilibrado desarrollo de dicho sistema en su conjunto, en protección de los intereses del público.

La estructura de esta ley se define como sigue: "De la naturaleza, objeto y facultades"; "De la naturaleza y objeto"; "De las facultades"; "De la organización"; "De las bases de la organiza-

63 Quintana Adriano, Elvia Arcelia, Ciencia del derecho mercantil, México, Porrúa p. 443.

64 El 1o. de mayo de 1995 se publicó en el Diario Oficial de la Federación la entrada en vigor la Ley de la Comisión Nacional Bancaria y de Valores, y el 12 de noviembre de 2014 se publicó en el Diario Oficial de la Federación el Reglamento Interior correspondiente. 
ción"; "De la Junta de Gobierno"; "De la Presidencia", y "De las disposiciones generales".

\section{Ley de Instituciones de Seguros y Fianzas (CNSF) ${ }^{65}$}

Esta ley tiene por objeto regular la organización, operación y funcionamiento de las instituciones de seguros, instituciones de fianzas y sociedades mutualistas de seguros; las actividades y operaciones que las mismas podrán realizar, así como las de los agentes de seguros y de fianzas, y demás participantes en las actividades aseguradora y afianzadora previstos en este ordenamiento, en protección de los intereses del público usuario de estos servicios financieros. ${ }^{66}$

Esta ley se encuentra constituida de la siguiente manera: "De las disposiciones preliminares"; "De las instituciones"; "De la organización y gobierno corporativo de lasinstituciones"; "De los demás participantes en los sistemas asegurador y afianzador"; "Del funcionamiento, operación y normas prudenciales"; "De los procedimientos"; "De las prohibiciones a las instituciones"; "De la contabilidad e información de las instituciones"; "De las medidas preventivas y correctivas, la intervención y la revocación"; "De las sociedades mutualistas de seguros"; "De la Comisión Nacional de Seguros y Fianzas"; "De la liquidación y el concurso mercantil", y "De las notificaciones, medidas de apremio y sanciones".

El Reglamento de esta ley tiene por objeto establecer la estructura, organización y funcionamiento de la Comisión Nacio-

65 El 4 de abril de 2013 se publicó en el Diario Oficial de la Federación el decreto por el que se expide la Ley de Instituciones de Seguros y de Fianzas. Esta nueva ley sustituye a la Ley General de Instituciones y Sociedades Mutualistas de Seguros y a la Ley Federal de Instituciones de Fianzas; el 3 de junio de 2015 se publicó en el Diario Oficial de la Federación su Reglamento Interior.

66 El 4 de abril de 2013 se publicó en el Diario Oficial de la Federación el decreto por el que se expide la Ley de Instituciones de Seguros y de Fianzas. Esta nueva ley sustituye a la Ley General de Instituciones y Sociedades Mutualistas de Seguros y a la Ley Federal de Instituciones de Fianzas. 
nal de Seguros y Fianzas, órgano administrativo desconcentrado de la Secretaría de Hacienda y Crédito Público, así como las atribuciones que podrán ejercer los órganos y unidades administrativas de dicha Comisión.

\section{Ley de los Sistemas de Ahorro para el Retiro (Consar)}

Esta ley tiene por objeto regular el funcionamiento de los sistemas de ahorro para el retiro y sus participantes previstos en esta Ley y en las leyes del Seguro Social, del Instituto del Fondo Nacional de la Vivienda para los Trabajadores y del Instituto de Seguridad y Servicios Sociales de los Trabajadores del Estado.

También establece que la coordinación, regulación, supervisión y vigilancia de los sistemas de ahorro para el retiro están a cargo de la Comisión Nacional del Sistema de Ahorro para el Retiro como órgano administrativo desconcentrado de la Secretaría de Hacienda y Crédito Público dotado de autonomía técnica y facultades ejecutivas. El artículo 5o. de esta ley establece las facultades de la Consar.

Los tópicos que se encuentran en esta son los siguientes: "Disposiciones preliminares", "De la Comisión Nacional del Sistema de Ahorro para el Retiro", "De los participantes en los sistemas de ahorro para el retiro", "De la cuenta individual y de los planes de pensiones establecidos por patrones o derivados de contratación colectiva", "De la supervisión de los participantes en los sistemas de ahorro para el retiro", "De las sanciones administrativas", "De los delitos y de las disposiciones generales".

\section{LEYES DE ORGANISMOS DE PROTECGIÓN AL SISTEMA}

\section{Ley de Protección al Ahorro Bancario (LPAB)}

La ley tiene por objeto establecer un sistema de protección al ahorro bancario en favor de las personas que realicen cualquier ope- 
ración garantizada, regular los apoyos financieros que se otorguen a las instituciones de banca múltiple para la protección de los intereses del público ahorrador, así como establecer las bases para la organización y funcionamiento de la entidad pública encargada de estas funciones.

Ahora bien, el Instituto de Protección al Ahorro Bancario atenderá los derechos de las instituciones bancarias en quiebra. El IPAB tiene sus facultades expresas en el artículo 67 de dicha ley.

La finalidad del instituto es devolver el dinero a los ahorradores (hasta por un monto de 400 mil UDIS), en caso de que una institución bancaria se declare en quiebra, suspensión de pagos o en liquidación.

Dentro de la ley podemos encontrar lo siguientes tópicos: "Objeto de la ley", "Del sistema de protección al ahorro bancario", "De los bienes", "Del Instituto para la Protección al Ahorro Bancario" y "De las Acciones".

\section{Ley de Protección y Defensa al Usuario de Servicios Financieros (Condusef)}

Esta ley tiene por objeto la protección y defensa de los derechos e intereses del usuario de los servicios financieros que prestan las instituciones públicas, privadas y del sector social, así como regular la organización, procedimientos y funcionamiento de la entidad pública encargada de dichas funciones.

La Comisión Nacional para la Protección y Defensa de los usuarios de servicios financieros tendrá como finalidad promover, asesorar, proteger y defender los derechos e intereses de los usuarios frente a las instituciones financieras, arbitrar sus diferencias y proveer a la equidad en las relaciones entre éstos, así como supervisar y regular a las instituciones financieras, a fin de procurar la protección de los intereses de los usuarios. 
La ley se estructura de la siguiente manera: "Disposiciones generales", "De las facultades, dirección y administración de la Comisión Nacional", "De las facultades de la Comisión Nacional", "De la dirección y administración de la Comisión Nacional", "De la organización y patrimonio de la Comisión Nacional", "De la organización de la Comisión Nacional", "De los consejos consultivos de la Comisión Nacional", y "De la vigilancia y control de la Comisión Nacional".

\section{LEYES Y DISPOSICIONES DE APLICACIÓN GENERAL}

\section{Banca comercial}

\section{A. Ley de Instituciones de Crédito}

La Ley de Instituciones de Crédito (LIC) regula todo lo concerniente a la prestación del servicio de banca y crédito, mediante instituciones de banca múltiple y banca de desarrollo. En lo que respecta a esta última, establece que se regirán por su respectiva ley orgánica, y en su defecto por las leyes supletorias en el orden legalmente señalado por la LIC.

Por lo que respecta a las instituciones de banca comercial, regula las operaciones bancarias: activas, pasivas, de servicio o neutras así como las actividades que pueden realizar; su sano y equilibrado desarrollo, protección de intereses del público; y términos en que el Estado ejercerá la rectoría financiera del sistema bancario mexicano.

La LIC regula lo siguiente: las disposiciones preliminares, las instituciones de crédito, las operaciones, las disposiciones generales y la contabilidad, las prohibiciones, sanciones administrativas y delitos, la protección de los intereses del público y la Comisión Nacional Bancaria y de Valores. 


\section{B. Ley para Regular las Agrupaciones Financieras}

Esta ley es de orden público y de observancia general en los Estados Unidos Mexicanos y tiene por objeto regular las bases de organización de las sociedades controladoras y el funcionamiento de los grupos financieros, así como establecer los términos bajo los cuales habrán de operar, buscando la protección de los intereses de quienes celebren operaciones con las entidades financieras integrantes de dichos grupos financieros.

Las autoridades financieras, cada una en la esfera de su respectiva competencia, ejercerán sus atribuciones procurando: el desarrollo equilibrado del sistema financiero del país, con una apropiada cobertura regional; una adecuada competencia entre los participantes en dicho sistema; la prestación de los servicios integrados conforme a sanas prácticas y usos financieros; el fomento del ahorro interno y su adecuada canalización hacia actividades productivas; así como, en general, que el sistema citado contribuya al sano crecimiento de la economía nacional.

El contenido de esta ley es el siguiente: "De las disposiciones preliminares", "De la organización de las sociedades controladoras y la constitución y funcionamiento de grupos financieros", "De las filiales de instituciones financieras del exterior", "De la oferta de servicios conjuntos", "De las inversiones de la sociedad controladora", "De la protección de los intereses del público", "De la revocación, liquidación, separación e intervención de los grupos financieros", "De los procedimientos administrativos", y "De los consejos de coordinación de autoridades financieras".

\section{Ley General de Titulos y Operaciones de Crédito}

La Ley General de Títulos y Operaciones de Crédito se encarga de regular y sentar las normas para la actividad financiera en México. Fue creada en 1932, con la finalidad de establecer regulaciones entre los clientes y los prestadores de servicios financieros. 
Esta ley se renueva y se actualiza con regularidad para adaptarse a las necesidades financieras que surgen día con día. Regula los títulos y operaciones de crédito, reglamenta actos de comercio y contempla los siguientes aspectos: "De los títulos de crédito" y "De las operaciones de crédito".

\section{Ley General de Organizaciones y Actividades Auxiliares del Crédito}

Regula la organización y funcionamiento de las organizaciones auxiliares del crédito. La Secretaría de Hacienda y Crédito Público será el órgano competente para interpretar a efectos administrativos los preceptos de esta ley y, en general, para todo cuanto se refiera a las organizaciones y actividades auxiliares del crédito. Sus actividades son las siguientes: almacenamiento de bienes y mercancías, arrendamiento financiero mediante la celebración de un contrato, factoraje, otorgamiento de créditos a sus socios.

\section{E. Ley para Regular las Sociedades de Información Crediticia}

Esta ley tiene por objeto regular la constitución y operación de las sociedades de información crediticia.

Los burós de crédito son instituciones financieras, autorizadas por la SHCP, previa opinión del Banco de México y de la GNBV. Oficialmente, este tipo de entidades es conocida como Sociedades de Información Crediticia, en adelante, SIC, y son organizaciones que proporcionan servicios de recopilación, manejo y entrega o envío de información relativa al historial crediticio de personas físicas y morales.

Su objetivo es contribuir al desarrollo económico del país ofreciendo servicios que promuevan la minimización del riesgo crediticio al proporcionar información que ayude a conocer la experiencia de pago de empresas y personas físicas, lo que a su 
vez contribuye a formar la cultura del crédito entre la población, al tiempo de estimular un sano consumo interno.

Los burós de crédito, se forman por las siguientes empresas definidas como sociedades de información crediticia:

- Trans Unión de México, S. A., Buró de Personas Físicas, la primera sociedad de información crediticia en México autorizada por la SHCP surge con el fin de proporcionar información del comportamiento crediticio de personas físicas.

- Dun \& Bradstreet de México, S. A., sociedad de información crediticia, buró de Personas morales, surge con el fin de proporcionar información sobre el comportamiento crediticio de personas morales, y físicas con actividad empresarial.

- Círculo de Crédito, S. A. de C. V., sociedad de información crediticia, surge con el fin de proporcionar información sobre el comportamiento de crédito del segmento no bancarizado del país.

La ley se estructura con: "Disposiciones generales", "De las sociedades de información crediticia", "De la base de datos", "De la prestación de servicio de información crediticia", "De la protección de los intereses del cliente", "De las sanciones y de quitas y reestructuras".

\section{F. Ley para la Transparencia y Ordenamiento de los Servicios Financieros}

Tiene por objeto regular las comisiones y cuotas de intercambio así como otros aspectos relacionados con los servicios financieros y el otorgamiento de créditos de cualquier naturaleza que realicen las entidades financieras o comerciales, para garan- 
tizar la transparencia, eficiencia del sistema de pagos y protección de los intereses del público.

Esta ley comprende los siguientes apartados: "Disposiciones generales", "De la comisiones y cuotas de intercambio", "De la transparencia en relación con los medios de disposición y en el otorgamiento de créditos, préstamos y financiamientos", "De los créditos, préstamos o financiamientos revolventes asociados a una tarjeta", "Disposiciones comunes", "Del proceso administrativo sancionador", y "Del recurso de revisión y de la ejecución de multas".

\section{G. Ley de Uniones de Crédito}

Esta ley tiene por objeto regular la organización y funcionamiento de las uniones, así como las operaciones que las mismas podrán realizar. Se encuentra integrada por las siguientes secciones: "Disposiciones generales", "De la organización y funcionamiento de las uniones de crédito", "De las operaciones", "De la contabilidad, inspección y vigilancia", "De las facultades de las autoridades", y "De las prohibiciones, infracciones, delitos y notificaciones".

\section{Banca de desarrollo}

\section{A. Ley del Desarrollo Rural Sustentable}

Esta ley tiene por objeto promover el desarrollo rural sustentable del país, propiciar un medio ambiente adecuado y garantizar la rectoría del Estado y su papel en la promoción de la equidad. El desarrollo rural sustentable incluye la planeación y organización de la producción agropecuaria, su industrialización y comercialización, y de los demás bienes y servicios, y todas aquellas acciones tendentes a la elevación de la calidad de vida de la población rural. 
Son sujetos de esta Ley los ejidos, comunidades y las organizaciones o asociaciones de carácter nacional, estatal, regional, distrital, municipal o comunitario de productores del medio rural, que se constituyan o estén constituidas de conformidad con las leyes y, en general, toda persona física o moral que, de manera individual o colectiva, realice preponderantemente actividades en el medio rural.

Los títulos o aspectos en que está estructurada la ley son: "Del objeto y aplicación de la ley", "De la planeación y coordinación de la política para el desarrollo rural sustentable", "De la planeación del desarrollo rural sustentable", "De la coordinación para el desarrollo rural sustentable", "De la federalización y a descentralización", "De los distritos de desarrollo rural", "Del fomento agropecuario y desarrollo rural sustentable", "Del fomento a las actividades económicas del desarrollo rural", "De la investigación y la transferencia tecnológica", "De la capacitación y asistencia técnica", "De la reconversión productiva sustentable", "De la capitalización rural, compensaciones y pagos directos", "Del incremento de la productividad y la formación y consolidación de empresas rurales", "De la sanidad agropecuaria", "De la normalización e inspección de los productos agropecuarios y del almacenamiento y de la inspección y certificación de semillas", "De la comercialización", "Del Sistema Nacional de Financiamiento Rural", "De la administración de riesgos", "De la información económica y productiva", "De la organización económica y los sistemas de producto", "Del bienestar social y atención prioritaria a las zonas de marginación", "De las sustentabilidad de la producción rural", "De la seguridad y soberanía alimentaria", "Del servicio nacional de arbitraje de los productos ofertados por la Sociedad Rural" y "De los apoyos económicos".

\section{B. Ley de Fondos de Aseguramiento Agropecuario y Rural}

Esta ley es de orden público y tiene por objeto crear y regular la organización, funcionamiento y operación del sistema de 
fondos de aseguramiento agropecuario y rural, que se constituirá por los fondos de aseguramiento y por sus organismos integradores, que se registren ante la Secretaría de Hacienda y Crédito Público con los siguientes propósitos específicos:

I. Fomentar, promover y facilitar el servicio de aseguramiento por parte de los Fondos de Aseguramiento Agropecuario y Rural;

II. Regular las actividades y operaciones que los Fondos de Aseguramiento Agropecuario y Rural podrán realizar, así como establecer el servicio de Asesoría Técnica y Seguimiento de Operaciones que deberán recibir, con el propósito de lograr su sano y equilibrado desarrollo;

III. Regular la organización, funcionamiento y operaciones de los Organismos Integradores de los Fondos de Aseguramiento Agropecuario y Rural;

IV. Otorgar certeza y seguridad jurídica en la protección de los intereses de quienes celebran operaciones con dichos Fondos de Aseguramiento Agropecuario y Rural, y

V. Establecer los términos en que se llevará a cabo el seguimiento de operaciones del Sistema de Fondos de Aseguramiento Agropecuario y Rural.

La Secretaría de Hacienda y Crédito Público será la dependencia competente para interpretar en sus aspectos administrativos los preceptos de esta ley y en general, para todo cuanto se refiere a los sujetos de la misma. Para estos efectos, la secretaría podrá solicitar, cuando así lo considere conveniente, la opinión de algún organismo, dependencia o entidad en razón de la naturaleza de los casos que lo ameriten.

Dentro de esta ley, podemos encontrar los siguientes apartados: "Objeto y aplicación de la ley", "De la planeación y coordinación de la política para el desarrollo rural sustentable", "Del fomento agropecuario y de desarrollo rural sustentable", y "De los apoyos económicos". 


\section{Ley Orgánica de la Financiera Nacional de Desarrollo Agropecuario Rural, Forestal y Pesquero}

Esta ley crea y rige a la Financiera Nacional de Desarrollo Agropecuario, Rural, Forestal y Pesquero, como organismo descentralizado de la administración pública federal, sectorizado en la Secretaría de Hacienda y Crédito Público, con personalidad jurídica y patrimonio propios.

La Financiera tendrá como objeto coadyuvar a realizar la actividad prioritaria del Estado de impulsar el desarrollo de las actividades agropecuarias, forestales, pesqueras y todas las demás actividades económicas vinculadas al medio rural, con la finalidad de elevar la productividad, así como de mejorar el nivel de vida de su población. Para el cumplimiento de dicho objeto, otorgará crédito de manera sustentable y prestará otros servicios financieros a los productores e intermediarios financieros rurales, procurando su mejor organización y mejora continua. Asimismo, ejecutará los programas que en materia de financiamiento rural se determinen en el Presupuesto de Egresos de la Federación. Adicionalmente, promoverá ante instituciones nacionales e internacionales orientadas a la inversión y al financiamiento, proyectos productivos que impulsen el desarrollo rural. Además, operará con los gobiernos federal, estatales y municipales, los programas que se celebren con las instituciones mencionadas.

La Financiera apoyará actividades de capacitación y asesoría a los Productores para la mejor utilización de sus recursos crediticios, así como para aquellos que decidan constituirse como intermediarios financieros rurales.

En el desarrollo de su objeto y con el fin de fomentar el desarrollo integral del sector rural, la Financiera coadyuvará al mejoramiento del sector financiero del país vinculado a las actividades agropecuarias, forestales, pesqueras y del medio rural y manejará sus recursos de manera prudente, eficiente y transparente. 
Dentro de esta ley podemos encontrar los siguientes apartados: "Disposiciones preliminares", "De las operaciones de la financiera", "Del patrimonio de la financiera", "De la administración de la financiera", "De la información", "Del control, vigilancia y evaluación de la financiera", y "De las disposiciones finales".

\section{Ley Orgánica de Nacional Financiera}

Esta ley rige a Nacional Financiera, sociedad nacional de crédito, institución de banca de desarrollo, con personalidad jurídica y patrimonio propios.

Nacional Financiera tendrá por objeto promover el ahorro y la inversión, así como canalizar apoyos financieros y técnicos al fomento industrial y en general, al desarrollo económico nacional y regional del país.

La operación y funcionamiento de la institución se realizará con apego al marco legal aplicable y a las sanas prácticas y usos bancarios para alcanzar los objetivos de carácter general señalados en el artículo 4o. de la Ley de Instituciones de Crédito.

Dentro de esta ley podemos encontrar lo siguientes apartados: denominación, objeto y domicilio, objetivos y operaciones, capital social, administración y vigilancia y disposiciones generales.

\section{E. Ley Orgánica de Sociedad Hipotecaria Federal}

Esta ley tiene por objeto regular la organización y el funcionamiento de Sociedad Hipotecaria Federal, Sociedad Nacional de Crédito, Institución de Banca de Desarrollo.

Sociedad Hipotecaria Federal, Sociedad Nacional de Crédito, tendrá por objeto impulsar el desarrollo de los mercados primario y secundario de crédito a la vivienda, mediante el otor- 
gamiento de crédito y garantías destinadas a la construcción, adquisición y mejora de vivienda, preferentemente de interés social en los términos de esta Ley, así como al incremento de la capacidad productiva y el desarrollo tecnológico, relacionados con la vivienda.

Asimismo, podrá garantizar financiamientos relacionados con el equipamiento de conjuntos habitacionales.

La Sociedad Hipotecaria Federal desarrollará programas que promuevan la construcción de viviendas en zonas y comunidades indígenas en el territorio nacional con los recursos que se aprueben para tal efecto en el presupuesto de egresos.

Para efectos de esta ley, se entenderá por mercado secundario de créditos, todas aquellas operaciones por medio de las cuales se efectúe la venta de la cartera hipotecaria, fiduciaria o de títulos emitidos con la garantía de dicha cartera a terceras personas.

Dentro de esta ley se pueden encontrar los siguientes apartados: "Naturaleza, objeto y domicilio"; "Operaciones"; "Capital social", y "Administración y vigilancia y disposiciones generales".

\section{F. Ley Orgánica del Banco del Ahorro Nacional y Servicios Financieros}

Esta ley rige al Banco del Ahorro Nacional y Servicios Financieros, con el carácter de Sociedad Nacional de Crédito, Institución de Banca de Desarrollo, con personalidad jurídica y patrimonio propios.

El Banco del Ahorro Nacional y Servicios Financieros, Sociedad Nacional de Crédito, Institución de Banca de Desarrollo, realiza funciones de banca social, para lo cual tiene por objeto promover y facilitar el ahorro, el acceso al financiamiento, la inclusión financiera, el fomento de la innovación, la perspectiva de género y la inversión entre los integrantes del sector, ofrecer instrumentos y servicios financieros de primer y segundo piso entre los mismos, así como canalizar apoyos financieros y técnicos necesarios para 
fomentar el hábito del ahorro y el sano desarrollo del sector y en general, al desarrollo económico nacional y regional del país, así como proporcionar asistencia técnica y capacitación a los integrantes del sector.

El Banco del Ahorro Nacional y Servicios Financieros, sociedad nacional de crédito, institución de banca de desarrollo, podrá operar bajo cualquier nombre comercial.

Las instituciones de banca de desarrollo atenderán las actividades productivas que el Congreso de la Unión determine como especialidad de cada una de éstas, en las respectivas leyes orgánicas.

En esta ley, podemos encontrar los siguientes apartados: "Denominación, definiciones, objeto y domicilio"; "Objetivos y operaciones"; "Capital social"; "Administración"; "Vigilancia", y "Disposiciones generales y régimen laboral".

\section{G. Ley Orgánica del Banco Nacional de Comercio Exterior}

Rige al Banco Nacional de Comercio Exterior, Sociedad Nacional de Crédito, institución de banca de desarrollo, con personalidad jurídica y patrimonio propios.

La Sociedad, en su carácter de banca de desarrollo, prestará el servicio público de banca y crédito con sujeción a los objetivos y prioridades del Plan Nacional de Desarrollo, y en especial de los Programas Nacionales de Financiamiento del Desarrollo y de Fomento Industrial y de Comercio Exterior, para promover y financiar las actividades y sectores que le son encomendados en la propia Ley.

El Banco Nacional de Comercio Exterior, como institución de banca de desarrollo, tendrá por objeto financiar el comercio exterior del país, así como participar en la promoción de dicha actividad.

Con el fin de procurar la eficiencia y la competitividad del comercio exterior comprendiendo la pre exportación, exporta- 
ción, importación y sustitución de importación de bienes y servicios; en el ejercicio de su objeto estará facultado para otorgar apoyos financieros; otorgar garantías de crédito y las usuales en el comercio exterior; proporcionar información y asistencia financiera a los productores, comerciantes distribuidores y exportadores, en la colocación de artículos y prestación de servicios en el mercado internacional; cuando sea del interés el promover las exportaciones mexicanas, podrá participar en el capital social de empresas de comercio exterior, consorcios de exportación y empresas que otorguen seguro de crédito al comercio exterior. Asimismo, podrá participar en el capital social de sociedades de inversión y sociedades operadoras de éstas; promover, encauzar y coordinar la inversión de capitales a las empresas dedicadas a la exportación; otorgar financiamiento a los exportadores indirectos y en general al aparato productivo exportador, a fin de optimizar la cadena productiva de bienes o servicios exportables, así como coadyuvar en el fomento del comercio exterior del país y realizar todos los actos y gestiones que permitan atraer inversión extranjera al país; cuando sea de interés promover las exportaciones mexicanas, podrá otorgar apoyos financieros a las empresas comercializadoras de exportación, consorcios y entidades análogas de comercio exterior; propiciar acciones conjuntas de financiamiento y asistencia en materia de comercio exterior con otras instituciones de crédito, fondos de fomento, fideicomisos, organizaciones auxiliares del crédito y con los sectores social y privado; propiciar acciones conjuntas de financiamiento y asistencia para las personas, empresas y organizaciones productivas y de comercialización, en pueblos y comunidades indígenas, en materia de comercio exterior con otras instituciones de crédito, fondos de fomento, fideicomisos, organizaciones auxiliares del crédito y con los sectores social y privado; podrá ser agente financiero del gobierno federal en lo relativo a la negociación, contratación y manejo de créditos del exterior, ya sea que éstos sean otorgados por instituciones del extranjero, privadas, gubernamentales e intergubernamentales; participar en la negociación y, en su caso, 
en los convenios financieros de intercambio compensado o de créditos recíprocos, que señale la Secretaría de Hacienda y Crédito Público; estudiar políticas, planes y programas en materia de fomento al comercio exterior y su financiamiento, y someterlos a la consideración de las autoridades competentes; fungir como órgano de consulta de las autoridades competentes, en materia de comercio exterior y su financiamiento; participar en las actividades inherentes a la promoción del comercio exterior, tales como difusión, estudio de productos y servicios exportables, sistemas de venta, apoyo a la comercialización y organización de productores, comerciantes, distribuidores y exportadores; opinar, a solicitud que le formulen directamente las autoridades competentes, sobre tratados y convenios que el país proyecte celebrar con otras naciones, en materia de comercio exterior y su financiamiento; participar en la promoción de la oferta exportable; cuando se lo solicite podrá actuar como conciliador y arbitro en las controversias en que intervienen importadores y exportadores con domicilio en la República mexicana.

Para el cumplimiento de los objetivos podrá:

I. Realizar las operaciones y prestar los servicios.

II. Participar en el capital social de empresas.

III. Emitir bonos bancarios de desarrollo. Dichos títulos procurarán fomentar el desarrollo del mercado de capitales y la inversión institucional, y serán susceptibles de colocarse entre el gran público inversionista.

IV. Contratar créditos cuyos recursos se canalicen hacia su sector.

V. Administrar por cuenta propia o ajena toda clase de empresas o, sociedades.

VI. Otorgar garantías previas a la presentación de una oferta, sostenimiento de la oferta, de ejecución, de devolución y al exportador; y garantizar obligaciones de terceros, ya sea a través de operaciones particulares o de programas masivos de garantías.

VII. Realizar las actividades análogas y conexas a sus objetivos en los términos que al efecto le señale la Secretaría de Hacienda y Crédito Público. 
Dentro de esta ley, podemos encontrar los siguientes apartados: "De la sociedad, denominación, objeto y domicilio"; "Objetivos y operaciones"; "Capital social", y "Administración y vigilancia y disposiciones generales".

\section{H. Ley Orgánica del Banco Nacional de Obras y Servicios Públicos}

Esta ley rige al Banco Nacional de Obras y Servicios Públicos, Sociedad Nacional de Grédito, institución de banca de desarrollo, con personalidad jurídica y patrimonio propios.

La Sociedad, en su carácter de banca de desarrollo, prestará el servicio público de banca y crédito con sujeción a los objetivos y prioridades del Plan Nacional de Desarrollo, y en especial del Programa Nacional de Financiamiento del Desarrollo, de acuerdo a los programas sectoriales y regionales y a los planes estatales y municipales, para promover y financiar las actividades y sectores.

El Banco Nacional de Obras y Servicios Públicos, como institución de banca de desarrollo, tendrá por objeto financiar o refinanciar proyectos relacionados directa o indirectamente con inversión pública o privada en infraestructura y servicios públicos, así como con las mismas operaciones coadyuvar al fortalecimiento institucional de los gobiernos Federal, estatal y municipal, con el propósito de contribuir al desarrollo sustentable del país.

Dentro de esta ley, se encontrarán los siguientes aspectos: "De la sociedad, denominación, objeto y domicilio"; "Objetivos y operaciones"; "Capital social; "Administración y vigilancia", y "Disposiciones generales".

\section{Sector bursátil}

\section{A. Ley del Mercado de Valores}

La Ley del Mercado de Valores entró en vigor el 30 de diciembre del 2005. ${ }^{67}$ Regula la oferta pública de valores (la que se

67 Última reforma publicada en el Diario Oficial de la Federación el 10 de enero de 2014 . 
haga por un medio de comunicación masiva o a persona indeterminada para suscribir, enajenar, o adquirir los valores, acciones, obligaciones, bonos, certificados y demás títulos de crédito y documentos que se emitan en serie o en masa), la intermediación en el mercado, las actividades de las personas que intervienen en él. La actividad de intermediación la hacen las casas de bolsa, que son sociedades anónimas autorizadas por la SHCP para intervenir profesionalmente en la colocación de valores, acercando a los inversionistas con exceso de liquidez y a los emisores, personas que desean allegarse recursos para canalizarlos a sus actividades productivas.

La LMV se divide en catorce títulos, correspondientes a "Disposiciones preliminares"; "De las sociedades anónimas del mercado de valores"; "De los certificados bursátiles", "Títulos opcionales y otras disposiciones"; "De la inscripción y oferta de valores", y "De las infracciones y prohibiciones de mercado".

\section{B. Ley de Fondos de Inversión}

La Ley de Fondos de Inversión tiene por objeto regular la organización y funcionamiento de los fondos de inversión, la intermediación de las acciones que emitan éstas en el mercado de valores, así como los servicios que deberán contratar para el correcto desempeño de sus funciones. Los fondos de inversión se constituyen como sociedades anónimas autorizadas por la $\mathrm{CNBV}$ para adquirir y vender activos objeto de inversión, títulos y documentos a los que les resulte aplicable el régimen de la LMV, con recursos provenientes de la colocación de acciones representativas de su capital social entre el público inversionista. Así, es obligación de las autoridades la consecución de los siguientes objetivos: 1) el fortalecimiento y descentralización del mercado de valores; 2) el acceso del pequeño y mediano inversionista a dicho mercado; 3) la diversificación del capital, y 4) la contribución al 
financiamiento de la actividad productiva del país, y la protección de los intereses del público inversionista.

\section{Leyes del sector de ahorro y crédito popular}

\section{A. Ley de Ahorro y Crédito Popular}

Esta ley tiene por objeto regular, promover y facilitar la captación de fondos o recursos monetarios y su colocación mediante préstamos o créditos u otras operaciones por parte de las sociedades financieras populares, sociedades financieras comunitarias; así como los organismos de integración financiera rural; regular, promover y facilitar las actividades y operaciones de estas últimas, su sano y equilibrado desarrollo; proteger los intereses de sus clientes, y establecer los términos en los que el estado ejercerá la rectoría de las referidas sociedades financieras populares.

Dentro de esta ley podemos encontrar los siguientes apartados: "Disposiciones generales"; "De la organización y funcionamiento de las sociedades financieras populares, sociedades financieras comunitarias y organismos de integración financiera rural"; "De las federaciones, medidas correctivas y del fondo de protección"; "De los organismos auto regulatorios"; "De la regulación prudencial y de la contabilidad"; "De las facultades de las autoridades", y "De las sanciones, delitos y notificaciones".

\section{B. Ley para Regular las Actividades de las Sociedades Cooperativas de Ahorro y Préstamo}

Esta ley reconoce a las sociedades cooperativas de ahorro y préstamo, quienes son integrantes del sector social de la economía, y tiene por objeto: 
Regular, promover y facilitar la captación de fondos o recursos monetarios y su colocación mediante préstamos, créditos $\mathrm{u}$ otras operaciones por parte de las sociedades cooperativas de ahorro y préstamo con sus socios; regular, promover y facilitar las actividades y operaciones de estas últimas, su sano y equilibrado desarrollo; proteger los intereses de los socios ahorradores, y establecer los términos en que el Estado ejercerá las facultades de supervisión, regulación y sanción.

Esta ley se integra por los siguientes apartados: "Disposiciones generales", "De las sociedades cooperativas de ahorro y préstamo", "De la organización y la regulación de las sociedades cooperativas de ahorro y préstamo", "Del fondo de protección, de las facultades de las autoridades", "De la escisión, fusión, disolución y liquidación o concurso mercantil", y "De las sanciones, delitos y notificaciones".

\section{Disposiciones complementarias}

\section{a. Circulares}

Son documentos que generan tanto la Secretaría de Hacienda y Crédito Público, la Comisión Nacional Bancaria y de Valores y la Comisión Nacional de Seguros y Fianzas, mediante los cuales dan a conocer a las instituciones del Sistema Financiero Mexicano; lineamientos y/u ordenamientos que no se encuentran incluidos en las leyes, pero que son indispensables cumplir con el fin de lograr el correcto funcionamiento del sistema financiero.

Estos documentos pueden incluir instructivos de cómo realizar ciertos trámites, así como tablas de referencias o formatos a utilizar.

\section{b. Usos y prácticas bancarias y comerciales}

Es preciso decir que sólo los usos, no la costumbre, ya que son cosas distintas, son fuente complementaria, lo cual se encuentra 
integrado en el artículo 6o. de la Ley de Instituciones de Crédito. Los usos son prácticas reiteradas, previamente convenidas y establecidas entre un número determinado de personas en sus transacciones mercantiles cotidianas, de allí que la diferencia entre el uso y la costumbre estriba en que aquél se restringe a un número determinado de personas, mientras que esta última se aplica a todos los miembros de una comunidad. Asimismo, mientras que la práctica bancaria son métodos reiterados aplicados y catalogados por las instituciones bancarias en sus manuales operativos internos, fijado unilateralmente por la institución para prestar un óptimo y más seguro servicio, el uso se encuentra más bien disperso, aunado a que puede ser convenido entre la institución bancaria y el cliente.

Los usos y prácticas bancarias y comerciales se refieren a tradiciones jurídicas existentes en el ámbito bancario y comercial, y en caso de que las leyes no contemplen ciertas situaciones, se actuará de acuerdo con estos usos y costumbres generalizados. 


\section{PARTE ESPECIAL}

\section{SEGTORES DEL SISTEMA FINANCIERO MEXICANO}




\section{CaPítulo QUiNTO \\ SEGTOR BANGARIO}

I. BANCA MÚLTIPLE

Las instituciones de banca múltiple se encuentran reguladas dentro del capítulo I del título II de la Ley de Instituciones de Crédito.

Para organizarse y operar como institución de banca múltiple se requiere autorización del gobierno federal, que compete otorgar discrecionalmente a la Comisión Nacional Bancaria y de Valores, previo acuerdo de su Junta de Gobierno y opinión favorable del Banco de México. Por su naturaleza, estas autorizaciones serán intransmisibles. ${ }^{68}$

1. Naturaleza jurídica de las instituciones de banca múltiple ${ }^{69}$

a) Son sociedades anónimas de capital fijo constituidas de acuerdo a lo que dispone en lo relativo a la sociedad anónima la Ley General de Sociedades Mercantiles.

b) Tendrán por objeto la prestación del servicio de banca y crédito, en los términos de la presente ley.

c) La duración de la sociedad será indefinida.

d) Deberán contar con el capital social y el capital mínimo que corresponda conforme a lo previsto en esta ley.

e) Su domicilio social estará en el territorio nacional.

68 Artículo 8o. de la Ley de Instituciones de Crédito.

69 Artículo 9o. de la Ley de Instituciones de Crédito. 
f) Los estatutos sociales, así como cualquier modificación a los mismos, deberán ser sometidos a la aprobación de la Comisión Nacional Bancaria y de Valores. Una vez aprobados los estatutos sociales o sus reformas, el instrumento público en el que consten deberá inscribirse en el Registro Público de Comercio sin que sea preciso mandamiento judicial.

g) El capital social de las instituciones de banca múltiple estará formado por una parte ordinaria y podrá también estar integrado por una parte adicional. El capital social ordinario de las instituciones de banca múltiple se integrará por acciones de la serie "O”. En su caso, el capital social adicional estará representado por acciones serie "L", que podrán emitirse hasta por un monto equivalente al cuarenta por ciento del capital social ordinario, previa autorización de la Comisión Nacional de Valores.

h) La administración de las instituciones de banca múltiple estará encomendada a un consejo de administración y a un director general, en sus respectivas esferas de competencia.

i) El órgano de vigilancia de las instituciones de banca múltiple, estará integrado por lo menos por un comisario designado por los accionistas de la serie "O" y, en su caso, un comisario nombrado por los de la serie "L", así como sus respectivos suplentes.

Asimismo, la Ley de Instituciones de Crédito regula las siguientes instituciones de banca múltiple:

- Instituciones de banca múltiple organizadas y operadas por el Instituto para la Protección al Ahorro Bancario. ${ }^{70}$

70 "El Instituto para la Protección al Ahorro Bancario podrá organizar y operar instituciones de banca múltiple, exclusivamente con el objeto de celebrar operaciones de transferencia de activos y pasivos de las instituciones de crédito en liquidación...", "tendrán una duración de hasta seis meses, que podrá prorrogarse por una sola vez y hasta por el mismo plazo, por acuerdo de la 
- Filiales de instituciones financieras del exterior. ${ }^{71}$

- Instituciones de banca múltiple que tengan vínculos de negocio o patrimoniales con personas morales que realicen actividades empresariales. ${ }^{72}$

Las instituciones de banca múltiple son instituciones de crédito privadas que se encargan de captar los ahorros de la población, mismos que utiliza posteriormente para el otorgamiento de crédito.

Estas instituciones se constituyen previa autorización de la Comisión Nacional Bancaria y de Valores, con opinión del Banco de México.

Sus principales actividades son:

\section{- Captación de recursos.}

- Otorgamiento de créditos.

- Operar con valores en los mercados financieros.

- Servicios de asesoría.

- Operar como fideicomisos.

- Administración y custodia de bienes.

- Servicios de caja y tesorería.

asamblea de accionistas". Artículos 27 bis 1 y 27 bis 2, Ley de Instituciones de Crédito.

71 Capítulo III de la Ley de Instituciones de Crédito. Artículo 45-A: “...Filial: La sociedad mexicana autorizada para organizarse y operar, conforme a esta Ley, como institución de banca múltiple, y en cuyo capital participe una Institución Financiera del Exterior o una Sociedad Controladora Filial; Institución Financiera del Exterior: La entidad financiera constituida en un país con el que México haya celebrado un tratado o acuerdo internacional en virtud del cual se permita el establecimiento en territorio nacional de Filiales; Sociedad Controladora Filial: La sociedad mexicana autorizada para constituirse y operar como sociedad controladora en los términos de la Ley para Regular las Agrupaciones Financieras, y en cuyo capital participe una Institución Financiera del Exterior".

72 Ley de Instituciones de Crédito, capítulo IV, "De las Instituciones de Banca Múltiple que tengan vínculos de negocio o patrimoniales con personas morales que realicen actividades empresariales", artículos 45-O al 45-T. 
Dentro de la banca múltiple existen los organismos autorregulatorios bancarios, a los que definiremos a continuación.

\section{Organismos autorregulatorios bancarios}

\section{A. Concepto}

Tendrán el carácter de organismos autorregulatorios bancarios las asociaciones o sociedades gremiales de instituciones de crédito que, a solicitud de aquellas, sean reconocidas con tal carácter por la Comisión Nacional Bancaria y de Valores, previo acuerdo de su Junta de Gobierno.

\section{B. Objeto}

Implementar estándares de conducta y operación entre sus agremiados, a fin de contribuir al sano desarrollo de las instituciones de crédito. Dichos organismos podrán ser de diverso tipo acorde con las actividades que realicen. ${ }^{73}$

La Comisión Nacional Bancaria y de Valores expedirá disposiciones de carácter general en las que establezca los requisitos que deberán cumplir las asociaciones o sociedades gremiales de instituciones de crédito para obtener, acorde con su tipo, el reconocimiento de organismo autorregulatorio, así como regular su funcionamiento.

Cabe resaltar que las normas de carácter general que expida la Comisión Nacional Bancaria y de Valores serán aquellas en las que establezca: a) los requisitos que deberán cumplir las asociaciones o sociedades gremiales de instituciones de crédito para obtener, acorde con su tipo; $b$ ) el reconocimiento de organismo autorregulatorio para regular su funcionamiento y c) preverán

73 Artículo 7 bis de la Ley de Instituciones de Crédito. 
requisitos relacionados con la organización y funcionamiento interno de las asociaciones y sociedades gremiales que quieran ser reconocidos como organismos de autorregulación, a fin de propiciar que sus órganos sociales se integren en forma equitativa, por personas con honorabilidad y capacidad técnica, se conduzcan con independencia y cuenten con la representativa del gremio para el ejercicio de sus actividades, así como cualquier otro que contribuya a su sano desarrollo.

Los organismos autorregulatorios bancarios podrán emitir normas relativas a:

- Los requisitos de ingreso, exclusión y separación de sus agremiados.

- Las políticas y lineamientos que deban seguir sus agremiados en la contratación con la clientela a la cual presten sus servicios.

- La revelación al público de información distinta o adicional a la que derive de esta ley.

- Las políticas y lineamientos de conducta tendientes a que sus agremiados y otras personas vinculadas a estos con motivo de un empleo, cargo o comisión en ellos, conozcan y se apeguen a la normativa aplicable, así como a los sanos usos y prácticas bancarios.

- Los requisitos de calidad técnica, honorabilidad e historial crediticio satisfactorio aplicables al personal de sus agremiados.

- La procuración de la eficiencia y transparencia en las actividades bancarias.

- El proceso para la adopción de normas y la verificación de su cumplimiento.

- Las medidas disciplinarias y correctivas que se aplicarán a sus agremiados en caso de incumplimiento, así como el procedimiento para hacerlas efectivas.

- Los usos y prácticas bancarias. 


\section{Actividades de los organismos autorregulatorios bancarios ${ }^{74}$}

- Podrán llevar a cabo certificaciones de capacidad técnica de empleados, funcionarios y directivos de las instituciones de crédito, así como de sus apoderado.

- Deberán llevar a cabo evaluaciones periódicas a sus agremiados, sobre el cumplimiento de las normas que expidan dichos organismos para el otorgamiento de las certificaciones a que se refiere el párrafo anterior. Cuando de los resultados de dichas evaluaciones puedan derivar infracciones administrativas o delitos, a juicio del organismo de que se trate, éste deberá informar de ello a la Comisión Nacional Bancaria y de Valores, sin perjuicio de las facultades de supervisión que corresponda ejercer a la propia Comisión. Asimismo, dichos organismos deberán llevar un registro de las medidas correctivas y disciplinarias que apliquen a las personas certificadas por ellos, el cual estará a disposición de la propia Comisión.

\section{Facultades de la Comisión Nacional Bancaria y de Valores} respecto a los organismos autorregulatorios bancarios

De acuerdo con lo que dispone el artículo 7o. bis 3, de la Ley de Instituciones de Crédito, la CNBV tendrá las siguientes facultades:

I. Vetar las normas de autorregulación que expidan los organismos autorregulatorios bancarios, cuando la propia Comisión considere que éstas puedan afectar el sano y equilibrado desarrollo del sistema financiero, en protección de los intereses del público, en cuyo caso tales normas no iniciarán su vigencia o quedarán sin efectos;

74 Artículo 7o. bis 1 de la Ley de Instituciones de Grédito. 
II. Ordenar la suspensión, remoción o destitución de los consejeros y directivos de los organismos autorregulatorios bancarios, así como imponer veto de tres meses hasta cinco años, a las personas antes mencionadas, cuando cometan infracciones graves o reiteradas a esta Ley y demás disposiciones de carácter general que emanen de ella, con independencia de las sanciones económicas que correspondan conforme a esta u otras leyes, y

III. Revocar el reconocimiento de organismos autorregulatorios bancarios cuando cometan infracciones graves o reiteradas a lo previsto en esta u otras leyes y demás disposiciones de carácter general que emanen de las mismas.

Para proceder en términos de lo previsto en las fracciones II y III de este artículo, dicha Comisión deberá contar con el previo acuerdo de su Junta de Gobierno. Antes de dictar la resolución correspondiente, la Comisión deberá escuchar al interesado y al organismo de que se trate.

Las resoluciones a que se refiere este artículo podrán ser recurridas ante la Comisión Nacional Bancaria y de Valores dentro de los quince días hábiles siguientes a la fecha en que se hubieren notificado. La propia Comisión, con aprobación de su Junta de Gobierno, podrá revocar, modificar o confirmar la resolución recurrida, previa audiencia del afectado.

\section{Servicio de banca y crédito}

De acuerdo con la Ley de Instituciones de Crédito, los servicios de banca y crédito sólo podrán prestarse por instituciones de crédito, que podrán ser: 1) instituciones de banca múltiple, y 2) instituciones de banca de desarrollo.

Un banco es una institución que realiza operaciones de banca, es decir, es prestatario y prestamista de crédito; recibe y concentra en forma de depósitos los capitales captados para ponerlos a disposición de quienes puedan hacerlos fructificar. 
La función de los bancos es la de servir como intermediarios del crédito y el dinero; son un instrumento valioso para el gobierno en la lucha contra la inflación, mediante las políticas económico-financieras que el Banco de México les impone a seguir, como es el caso del interés bancario.

Se denomina como "banca" a la actividad que realizan los bancos comerciales y de desarrollo en sus diferentes modalidades que conforman el sistema bancario y constituyen instituciones de intermediación financiera; esto es, que admiten dinero en forma de depósito, otorgando por ello un interés, tasa pasiva, para posteriormente, en unión de recursos propios, conceder créditos, descuentos y otras operaciones financieras por las cuales cobra un interés, tasa activa, comisiones y gastos, en su caso.

La banca tiene tres funciones principales:

- Administrar el ahorro.

- Transformar el ahorro en créditos para apoyar los proyectos productivos.

- Administrar el sistema de pagos que permite la liquidación de las operaciones comerciales.

Por su parte, la banca múltiple está integrada por todos los bancos comerciales o privados y las sociedades anónimas de capital fijo que hayan sido autorizados por el gobierno federal, a través de la SHCP, para realizar actividades del servicio de banca y crédito en operaciones activas, pasivas y de servicios.

\section{A. Captación de recursos del público en el mercado nacional}

Son los bancos los que realizan las mayores captaciones de dinero que canalizan hacia otros sectores que los necesitan y utilizan para desarrollar sus empresas; es por esto que se les llama intermediarios, porque el dinero pertenece a sus clientes y sólo se benefician, obtienen utilidades, de los márgenes de utilidad que 
les reporta al dar prestado, o canalizar ese mismo dinero en las operaciones activas que están autorizadas a realizar, como es el caso de los préstamos en sus diferentes clases y modalidades, contratos de apertura de crédito.

Es decir, la Ley de Instituciones de Crédito considera servicio de banca y crédito a la captación de recursos del público en el mercado nacional para su colocación en el público, mediante actos causantes de pasivo directo o contingente, quedando el intermediario obligado a cubrir el principal y, en su caso, los accesorios financieros de los recursos captados.

No se consideran operaciones de banca y crédito aquellas que, en el ejercicio de las actividades que les sean propias, celebren intermediarios financieros distintos a instituciones de crédito que se encuentren debidamente autorizados conforme a los ordenamientos legales aplicables. Dichos intermediarios en ningún caso podrán recibir depósitos irregulares de dinero en cuenta de cheques.

Existirá captación de recursos del público cuando: a) se solicite, ofrezca o promueva la obtención de fondos o recursos de persona indeterminada o mediante medios masivos de comunicación, o $b$ ) se obtengan o soliciten fondos o recursos de forma habitual o profesional.

Las instituciones de crédito que establezcan relaciones o vínculos de negocio, de hecho o de derecho, con algún tercero para la recepción masiva de recursos, en efectivo o en cheques, que impliquen la captación de recursos del público o pago de créditos a favor de las propias instituciones, deberán celebrar con dichos terceros un contrato de comisión mercantil para que éstos actúen en todo momento frente al público.

\section{B. Colocación de recursos en el público}

Se considera servicio de banca y crédito la captación de recursos del público en el mercado nacional para su colocación en el público, mediante actos causantes de pasivo directo o contin- 
gente, quedando el intermediario obligado a cubrir el principal $y$, en su caso, los accesorios financieros de los recursos captados. ${ }^{75}$

\section{Operaciones pasivas}

Se consideran "operaciones pasivas" a aquellas mediante las cuales los bancos resultan deudores de recursos, en relación con las personas físicas y morales que se los depositan, ya sea a la vista o en diferentes instrumentos a plazo.

Las operaciones pasivas son las siguientes:

- Depósito bancario de dinero en cuenta de cheques. ${ }^{76}$

- Depósito bancario de dinero en cuenta corriente. ${ }^{77}$

- Depósitos a plazo. ${ }^{78}$

- Bonos bancarios. ${ }^{79}$

- Emisión de obligaciones subordinadas. ${ }^{80}$

a. Depósito bancario de dinero

El depósito de una suma determinada de dinero en moneda nacional o en divisas o monedas extranjeras transfiere la propiedad al depositario y lo obliga a restituir la suma depositada en la misma especie.

Los depósitos que se constituyan en caja, saco o sobre cerrados no transfieren la propiedad al depositario, y su retiro quedará sujeto a los términos y condiciones que en el contrato mismo se señalen.

\footnotetext{
75 Ley de Instituciones de Crédito, artículo 2o.

76 Artículo 269 de la LGTOG.

77 Artículo 267 de la LGTOC.

78 Artículo 271 de la LGTOC.

79 Artículo 63 de la LGTOC.

80 Artículo 64 de la LIC.
} 
b. Depósito bancario de dinero en cuenta de cheques

Es una cuenta donde se deposita dinero con la posibilidad de realizar pagos mediante la utilización de títulos de crédito denominados cheques.

Este tipo de cuenta ayuda a llevar un control sobre los gastos y pagos realizados y, por lo general, tienen como adicional una tarjeta de débito para poder realizar extracciones en cajeros automáticos en sucursales bancarias.

Con este producto se pueden realizar pagos de bienes y servicios, impuestos y entre otros.

En el caso que se realice un cheque, pero la cuenta no tenga dinero o fondos, éste será devuelto, por lo que no se habrá realizado el pago. Además, es importante recordar que no todos los bancos ofrecen protección de sobregiros, por lo cual, en el caso de devolución de un cheque, se deberá pagar por los gastos ocasionados al realizar un cheque que no contaba con el importe requerido en la cuenta.

\section{c. Depósito bancario de dinero en cuenta corriente}

Es un contrato establecido entre una institución financiera de depósito y un cliente, por el que éste sitúa en aquélla cualquier cantidad de dinero y puede disponer de él en cualquier momento mediante valores o cheques; puede estar a nombre de personas físicas o de personas jurídicas, como compañías, sociedades y organizaciones.

Entre sus características están: la posibilidad de manejar el dinero a través de una tarjeta de débito, el giro de cheques personales, la solicitud de sobregiros y realizar pagos con la tarjeta en otros países.

Entre sus ventajas están: la posibilidad de realizar pagos diferidos con cheques. La realización de retiros y depósitos con cheques de otras entidades sin tener otros gastos. El pago que se rea- 
liza con los cheques se debita de la cuenta, y en el caso de que no haya dinero suficiente en la cuenta, si el banco ha autorizado un sobregiro, cubrirá el valor faltante para poder pagar el cheque. El sobregiro que se otorga por cheques o tarjeta de débito genera intereses desde el momento en que se otorga hasta que se realice el pago. No obstante, los bancos no están obligados a otorgar sobregiros, puede autorizarlos o no según sus políticas internas. Es práctica indebida girar cheques posdatados.

\section{d. Depósitos a plazo}

Un depósito a plazo, también llamado imposición a plazo fijo, es un producto que consiste en la entrega de una cantidad de dinero a una entidad bancaria durante un tiempo determinado. Transcurrido ese plazo, la entidad devuelve el dinero, junto con los intereses pactados. También puede ser que los intereses se pagan periódicamente mientras dure la operación. Los intereses se liquidan en una cuenta corriente.

Los depósitos a plazo tienen una "fecha de vencimiento", que es cuando se puede retirar el dinero y los intereses sin pagar por ello una penalización o comisión. No se puede disponer de la cantidad depositada hasta la fecha de vencimiento. Estos depósitos brindan mayor interés que los depósitos a la vista.

El interés ofrecido para un depósito a plazo depende del mercado y de la necesidad de las entidades de crédito de captar fondos.

Normalmente se pacta un interés fijo para la duración de los depósitos a plazo. Sin embargo, cada vez es más frecuente ofrecer tipos de interés variables o mixtos; es el caso de los depósitos estructurados, en los que, tras un periodo inicial a un tipo fijo, se aplica un tipo variable vinculado a la evolución de un índice, al valor de una cesta de acciones o incluso a la posibilidad de que ocurra un hecho futuro. 


\section{e. Bonos bancarios}

Los bonos son instrumentos financieros de deuda utilizados por entidades privadas o por entidades gubernamentales y que sirven para financiar a las mismas empresas. El bono es una de las formas de materializar los títulos de deuda, de renta fija o variable. Pueden ser emitidos por una institución pública, un Estado, un gobierno regional, un municipio o por una institución privada, empresa industrial, comercial o de servicios.

Son títulos normalmente colocados al nombre del portador, y que suelen ser negociados en algún mercado o bolsa de valores. El emisor se compromete a devolver el capital principal junto con los intereses, también llamados "cupón”. Este interés puede tener carácter fijo o variable, según un índice de referencia.

Es interesante mencionar que existen diversos tipos de bonos, entre los cuales aparecen los bonos convertibles, que pueden canjearse por acciones de emisión nueva a un valor ya fijado con anticipación, los bonos canjeables, posibles de ser cambiados por acciones ya existentes, los bonos cupón cero, sólo abonan intereses cuando se amortizan, los bonos de caja, emitidos por empresas y reembolsables al vencimiento fijado, los bonos de deuda perpetua, no contemplan la devolución del capital principal, sino que proponen el pago de intereses de manera indefinida, y los bonos basura, ofrecen un elevado rendimiento, ya que se consideran títulos de alto riesgo.

\section{f. Emisión de obligaciones subordinadas}

Las obligaciones subordinadas son productos de renta fija a largo plazo, te las vendían como producto bancario rentable, aunque conllevan un alto riesgo y una baja liquidez. Es un producto híbrido entre la deuda y las acciones. Sirve para que las empresas, ya sean entidades financieras o no, se financien y puedan, de esa forma, tener dinero para realizar inversiones. Así, 
cuando llega el vencimiento, la empresa que captó el dinero debe devolverlo íntegramente. Además, durante el plazo deberá pagar unos intereses prefijados.

La deuda subordinada tiene un vencimiento determinado, esto es, posee una fecha de emisión y de cierre determinada, dependiendo del banco que lo emita, y sin posibilidad de rescate anticipada a la fecha final.

El principal problema radica en que a diferencia de otros productos bancarios, existe un riesgo vinculado directamente a la solvencia de la entidad emisora, y puede perder, no sólo los intereses pactados, sino también el capital invertido.

\section{Operaciones activas}

Las operaciones activas consisten en el otorgamiento de créditos a personas u organizaciones mediante el cobro de intereses y comisiones. Los recursos proporcionados para los créditos son los que se captan mediante las operaciones pasivas.

Los elementos de las operaciones activas son: institución, sujeto, plazo, intereses, riesgo y condiciones legales.

\section{a. Apertura de crédito}

Es aquel por medio del cual una persona llamada acreditante, se obliga a poner a disposición de otra, llamada acreditado, una suma de dinero o/a contraer por cuenta del acreditado una obligación para que el mismo haga uso del crédito concedido en la forma y términos pactados, por lo que el acreditado quedará obligado a restituir al acreditante las sumas de que disponga, o a cubrirlo oportunamente por el importe de la obligación que contrajo, y en todo caso, a pagar los intereses, comisiones, gastos y otras prestaciones estipuladas de acuerdo con el artículo 291 de la LGTOC. 
b. Aperturas de crédito simples

Es aquel que, salvo pacto en contrario, el acreditado podrá disponer a la vista de la suma de dinero objeto del contrato. Una vez que se ha dispuesto de la totalidad, el mismo se extingue.

c. Apertura de crédito en cuenta corriente mediante tarjeta de crédito

Es un instrumento financiero a través del cual una institución, como emisor de la tarjeta, concede a su cliente, mediante la suscripción de un contrato de adhesión, una línea de crédito revolvente, hasta por un importe determinado, conocido como límite de crédito. En dicho contrato, la institución establece las condiciones bajo las cuales otorga el crédito al cliente, así como también la forma en que éste deberá retribuir o pagar a dicha institución sus adeudos.

Este tipo de instrumento cuenta con las siguientes características:

- Las tarjetas de crédito son intransferibles, es decir, deben ser emitidas por entes financieros autorizados a nombre de un titular; sin embargo, existe también la figura de tarjetas adicionales que se entregan a las personas que el titular designa.

- La tarjeta de crédito también cuenta con un número de identificación personal (NIP) que proporciona la institución emisora al titular de la tarjeta de manera confidencial, misma que puede utilizar en cajeros automáticos para realizar consultas de saldo o disponer de dinero en efectivo.

- La tarjeta de crédito se formaliza con un contrato de apertura de crédito en cuenta corriente. 
- Se trata de un crédito quirografario; es decir que se garantiza con la firma de pagarés o boucher.

- Los estados de cuenta son expedidos dentro de los cinco días siguientes a la fecha de corte.

- Existen tarjetas de crédito sólo para compras, no válidas para usar en cajeros automáticos.

d. Créditos directos, préstamos quirografarios, pagarés

Un préstamo quirografario es la acción de otorgar dinero a una persona física o moral, mediante su firma en un pagaré con fecha de vencimiento determinada, en el que se obliga a devolver la cantidad que recibió más los intereses generados de acuerdo con el plazo. Se utiliza principalmente para cubrir necesidades urgentes o temporales de dinero como capital de trabajo. Por lo regular se devuelve a través de su operación normal, es decir, compraventa, producción y cobranza. Para determinar el tiempo que tardará para reponerlo, es necesario conocer los ciclos de operación de la empresa. La razón financiera más importante para el análisis de este instrumento es el flujo de efectivo, ya que permite la evaluación de los montos y periodos en que se requiere este recurso y cuándo puede reponerse.

\section{E. Operaciones neutras o de servicios}

a. Fideicomiso, mandato y comisión mercantil

El fideicomiso es un negocio jurídico que se desarrolla dentro de una institución fiduciaria, es un contrato bilateral por cuanto impone a dos partes obligaciones recíprocas: el fideicomitente se obliga a enajenar bienes al fiduciario y éste se obliga a custodiarlos y administrarlos de acuerdo con las instrucciones recibidas. En el contrato de fideicomiso, celebrado entre fideicomitente y fiduciario, se trasmite la propiedad sin ninguna contraprestación. 
La contraprestación podrá existir en la etapa final de ejecución del contrato, cuando el fiduciario trasmita la propiedad al beneficiario indicado, salvo que esa trasmisión se realice a título gratuito.

El fideicomiso se diferencia del mandato o comisión, porque el fiduciario adquiere la propiedad de los bienes, se asemeja a esos contratos porque cuando dispone de ellos, lo hace siguiendo instrucciones y en interés del fideicomitente.

El mandato es un contrato por el cual una persona llamada mandatario se obliga a ejecutar por cuenta de otra denominada mandante los actos jurídicos que éste le encarga. ${ }^{81}$

El mandato y la comisión mercantil son contratos mediante los cuales una persona identificada como mandante o comitente le encomienda la realización de diversos actos jurídicos a otra persona que se le conoce como mandatario o comisionista.

El fiduciario actúa como mandatario o comisionista para realizar los actos jurídicos que le sean encomendados por el mandante o comitente en el contrato de mandato o comisión mercantil, según corresponda.

\section{b. Depositaria de títulos de crédito}

De acuerdo con el artículo 46 de la Ley de Instituciones de Crédito, éstas sólo podrán realizar lo siguiente:

- Recibir depósitos en administración o custodia, o en garantía por cuenta de terceros, de títulos o valores y en general de documentos mercantiles.

- Actuar como representante común de los tenedores de títulos de crédito.

81 López Monroy, José de Jesús, "Fideicomiso", Enciclopedia Furídica Latinoamericana, p. 315. 
c. Administración de bienes y manejo de contabilidades

Las instituciones de crédito sólo podrán llevar la contabilidad y los libros de actas y de registro de sociedades y empresas.

\section{d. Pagarés con aval bancario}

Un aval es una garantía por la cual una persona, el avalista, responde con su patrimonio del cumplimiento de una obligación principal que ha contraído un tercero, el avalado, frente a otro, el beneficiario. Cuando hablamos de aval bancario, el avalista sería el banco, el avalado un cliente del mismo, y el beneficiario aquel interesado en garantizar la obligación.

Entre el aval de un banco o de un particular no hay diferencias formales. La diferencia esencial estriba en la capacidad financiera del banco para poder responder ante la ejecución del aval. Se estima como más probable que el banco pague que lo haga un particular.

Conviene destacar que, en los avales, la obligación principal garantizada no tiene por qué ser de naturaleza financiera.

e. Intervención en la emisión de obligaciones y representante común. Servicios

Las instituciones de crédito sólo podrán acordar la emisión de obligaciones subordinadas.

f. Albaceazgo, sindicatura y liquidación de empresas

Las instituciones de crédito sólo podrán desempeñar el cargo de albacea. 
g. Práctica de avalúos

Las instituciones de crédito sólo podrán encargarse de hacer avalúos, que tendrán la misma fuerza probatoria que las leyes asignan a los hechos por corredor público o perito.

h. Operaciones con divisas y metales, oro y plata

Las instituciones de crédito sólo podrán realizar las siguientes: llevar a cabo por cuenta propia o de terceros, operaciones con oro, plata y divisas, incluyendo reportos sobre estas últimas.

A las instituciones de crédito les está prohibido comerciar con mercancías de cualquier clase. Estas operaciones deben ajustarse a lo previsto por la Ley del Banco de México.

\section{i. Operaciones como intermediario bursátil}

Los intermediarios bursátiles no son otra cosa más que las casas de bolsa que han sido autorizadas para actuar como intermediarios en el manejo del mercado de valores. Les brindan a los inversionistas, asesoría en la constitución de sus carteras de inversión.

\section{j. Depósito bancario de títulos}

Las instituciones de crédito sólo podrán recibir depósitos en administración o custodia, o en garantía por cuenta de terceros, de títulos o valores, y en general de documentos mercantiles.

\section{$k$. SPEI o transferencias bancarias}

Se utilizan como medio de pago gracias a los avances en materia de tecnología, que además ofrecen certeza y transparencia al sistema financiero mexicano. 
Existe también el sistema de pagos electrónicos interbancarios, SPEI; es un sistema desarrollado por el Banco de México y la banca comercial, que permite a los usuarios enviar y recibir depósitos de dinero de manera electrónica y rápida.

En estas operaciones es importante que se conozca el número CLABE de la cuenta que envía y de la receptora; es una operación más de la banca por Internet cuya seguridad gira en torno de no compartir sus claves de acceso, passwords, utilizar los dispositivos de generación de claves que proveen los bancos, tokens, tarjetas de claves, entro otros, así como utilizar computadoras ubicadas en lugares seguros, como son las de la oficina y las de casa; debe evitar las computadoras de los llamados "cibercafés" o lugares de servicio público.

En lo concerniente al comercio electrónico, la Ley Federal de Protección al Consumidor es la que protege los derechos de éste en transacciones hechas a través de Internet; todo proveedor está obligado a respetar los precios, garantías, cantidades, medidas, intereses, cargos, términos, plazos, fechas, modalidades, reservaciones y demás condiciones que haya ofrecido, pactado o convenido con el consumidor para la entrega del producto o prestación del servicio.

Para los contratos de compraventa de artículos, éstos no tienen una regulación en especial, y ésta no difiere a la de los contratos tradicionales en materia comercial y financiera que rigen las operaciones comerciales e intercambio de datos e información que se lleve a cabo a través de medios electrónicos y las razones para efectuar el consentimiento.

l. Servicio de cajas de seguridad

Los artículos 46, fracción XIII, y 78 de la Ley de Instituciones de Crédito, facultan a éstas a realizar la operación de servicios de cajas de seguridad.

El servicio de cajas de seguridad obliga a la institución que lo presta a responder de la integridad de las cajas y mediante el 
pago de la contraprestación correspondiente, mantener el libre acceso a ellas en los días y horas hábiles. El tomador de la caja es responsable por todos los gastos, daños y perjuicios que origine a la institución con motivo de su uso.

Las condiciones generales y el contrato que para la prestación de este servicio celebren las instituciones de crédito deberán estipular con claridad las causas, formalidades y requisitos que se observarán para que la institución pueda proceder, ante notario público, a la apertura y desocupación de la caja, así como lo relativo a la custodia de los bienes extraídos. ${ }^{82}$

$m$. Venta de cheques de caja y giros bancarios

Es aquel expedido por una institución de crédito para que sea pagado en sus propias sucursales o filiales. El cliente entrega al banco la cantidad de dinero por la que expedirá el cheque y éste será pagado en esa misma institución o en su caso podrá depositarse en una cuenta del beneficiario. Deben ser expedidos a nombre de una persona determinada, no al portador, y no son negociables, no pueden cederse sus derechos mediante un endoso.

Características particulares

- Deben ser nominativos, es decir, forzosamente deben estar emitidos a favor de una determinada persona física o moral.

- Es posible acudir a cualquier banco para su adquisición, sin importar que el cliente tenga o no una cuenta bancaria con esa institución.

- Estos cheques no se encuentran en una chequera común y corriente, son expedidos por el banco a petición del cliente.

82 Ley de Instituciones de Crédito, artículo 78. 
- Únicamente el beneficiario señalado en el cheque podrá cobrarlo o depositarlo en una cuenta bancaria a su nombre.

- No es endosable, por lo que no puede transmitirse su propiedad y derechos a otra persona.

- En caso de robo o extravío, no puede ser cobrado por otra persona, por lo que se puede cancelar.

- Es una forma de pago muy segura, ya que este tipo de cheque se expide una vez que el banco se ha cerciorado de que existen fondos suficientes para el pago del mismo, garantizando así que el beneficiario pueda cobrar estas cantidades.

- El banco cobra comisión por la expedición de estos cheques y esta cantidad no le será devuelta en caso de cancelación.

n. Cobrar y pagar créditos por cuenta de terceros

Las instituciones de crédito sólo podrán efectuar operaciones de factoraje financiero.

o. Valores sobre los cuales pueden operar los bancos

1) Emitidos por el gobierno:

A) CETES: los certificados de la Tesorería de la Federación son títulos de crédito al portador en los que se consigna la obligación de su emisor, el gobierno federal, de pagar una suma fija de dinero en una fecha predeterminada.

- Valor nominal: 10 pesos, amortizables en una sola exhibición al vencimiento del título.

- Plazo: las emisiones suelen ser a 28, 91, 182 y 364 días, aunque se han realizado emisiones a plazos mayores, y tienen la característica de ser los valores más líquidos del mercado. 
- Rendimiento: a descuento.

- Garantía: son los títulos de menor riesgo, ya que están respaldados por el gobierno federal.

B) Udibonos: este instrumento está indizado, ligado, al Índice Nacional de Precios al Consumidor (INPG) para proteger al inversionista de las alzas inflacionarias, y está avalado por el gobierno federal.

\section{- Valor nominal: 100 UDIS.}

- Plazo: de tres y cinco años con pagos semestrales.

- Rendimiento: operan a descuento y dan una sobretasa por encima de la inflación, tasa real del periodo correspondiente.

G) Bonos de desarrollo: conocidos como Bondes, son emitidos por el gobierno federal.

- Valor nominal: 100 pesos.

- Plazo: su vencimiento mínimo es de uno a dos años.

- Rendimiento: se colocan en el mercado a descuento, con un rendimiento pagable cada 28 días, CETES a 28 días o TIIE, la que resulte más alta. Existe una variante de este instrumento con rendimiento pagable cada 91 días, llamado "Bonde 91".

D) Pagaré de indemnización carretero: se le conoce como PIC-FARAG, por pertenecer al Fideicomiso de Apoyo al Rescate de Autopistas Concesionadas, es un pagaré avalado por el gobierno federal a través del Banco Nacional de Obras y Servicios, S. N. G. en el carácter de fiduciario.

\section{- Valor nominal: 100 UDIS.}

- Plazo: va de 5 a 30 años. 
- Rendimiento: el rendimiento en moneda nacional de este instrumento dependerá del precio de adquisición, con pago de la tasa de interés fija cada 182 días.

- Garantía: gobierno federal.

E) Bonos BPAS: emisiones del Instituto Bancario de Protección al Ahorro con el fin de hacer frente a sus obligaciones contractuales y reducir gradualmente el costo financiero asociado a los programas de apoyo a ahorradores.

- Valor nominal: 100 pesos, amortizables al vencimiento de los títulos en una sola exhibición.

- Plazo: 3 años.

- Rendimiento: se colocan en el mercado a descuento y sus intereses son pagaderos cada 28 días. La tasa de interés será la mayor entre la tasa de rendimiento de los CETES al plazo de 28 días y la tasa de interés anual más representativa que el Banco de México dé a conocer para los pagarés con rendimiento liquidable al vencimiento, PRLV al plazo de un mes.

- Garantía: gobierno federal.

2) Emitidos por otros integrantes del sistema financiero.

\section{TABLA 1. INTEGRANTES DEL SISTEMA FINANCIERO}

\begin{tabular}{|ll|}
\hline \multicolumn{1}{|c|}{ Emisor } & \multicolumn{1}{c|}{ Instrumento } \\
\hline Gobierno federal & $\begin{array}{l}\text { Certificados de tesorería (Cetes) } \\
\text { Bonos de Desarrollo (Bondes) } \\
\text { Bonos M }\end{array}$ \\
& $\begin{array}{l}\text { Bonos denominados en Udis (Udi- } \\
\text { bonos) Bonos IPAB (BPA, BPAT y } \\
\text { BPA182) }\end{array}$ \\
\hline $\begin{array}{l}\text { Instituto para la Protección al Ahorro } \\
\text { Bancario }\end{array}$ & $\begin{array}{l}\text { Bonos de Regulación Monetaria } \\
\text { (BREM) }\end{array}$ \\
\hline Banco de México & \\
\hline
\end{tabular}




\begin{tabular}{|ll|}
\hline \multicolumn{1}{|c|}{ Emisor } & \multicolumn{1}{c|}{ Instrumento } \\
\hline $\begin{array}{l}\text { Empresas paraestatales } \\
\text { e instituciones públicas }\end{array}$ & Certificados bursátiles y bonos \\
\hline Banca comercial & \\
& Aceptaciones bancarias \\
& Certificados de depósito \\
& Bonos bancarios \\
& Certificados bursátiles \\
& Obligaciones bancarias y pagarés \\
\hline Empresas privadas & Certificados bursátiles \\
& Papel comercial \\
& Obligaciones privadas \\
& Certificados de participación \\
& Ordinaria (CPO y CPI) \\
& Pagarés \\
\hline Gobiernos estatales y municipales & Certificados bursátiles \\
\hline
\end{tabular}

3) De deuda y de capital:

A) De deuda:

Los instrumentos de deuda son títulos, es decir documentos necesarios para hacer válidos los derechos de una transacción financiera, que representan el compromiso por parte del emisor (en este caso la entidad) de pagar los recursos prestados, más un interés pactado o establecido previamente, al poseedor del título (o inversionista), en una fecha de vencimiento dada. Los instrumentos del mercado de deuda comúnmente se clasifican según:

a) Su cotización. Se refiere a la forma en que se hacen públicos los precios de los títulos. Los instrumentos se dividen en los que se cotizan "a descuento" y los que se cotizan "a precio". Los valores a descuento se refieren a los instrumentos de deuda que no pagan intereses periódicamente, es decir, que no pagan cupones. El rendimiento que obtienen los inversionistas proviene de comprarlos 
"a descuento", esto es, a un precio menor a la cantidad que se debe pagar al momento del vencimiento. Este precio es conocido como valor nominal.

El valor nominal de un título está determinado en el documento del instrumento, y también se conoce como valor facial. Los valores que cotizan a precio pagan cupones, y el precio del instrumento es el resultado de sumar, al valor al día de hoy, todos los pagos de intereses que pagará el título en el futuro, conocido como el valor presente de los pagos de interés, más el valor presente del valor nominal del instrumento conocido como "principal". La diferencia entre el precio y el valor nominal del título se conoce como rendimiento.

b) Su colocación. Hay dos maneras de ofrecer instrumentos de deuda al público inversionista:

- Mediante colocación pública. La oferta de instrumentos se realiza a través de algún medio masivo de comunicación, como periódicos o boletines de la Bolsa Mexicana de Valores. Bajo esta modalidad, la asignación se puede realizar ya sea por medio de una subasta o, si ya se tiene una lista de clientes con lo que se negocia la venta antes de la colocación (lista de asignaciones previa), se dice que la asignación es "sindicada".

- Mediante colocación privada. Por lo general, esta oferta va dirigida a una persona o a un grupo de inversionistas determinados. Sin embargo, también se puede tener una lista de asignación previa. La diferencia radica en que no se hace del conocimiento de todos los participantes del mercado.

c) El tipo de tasa. Se refiere a los intereses previamente pactados que pagará el instrumento de deuda. Éstos pueden ser a tasa de interés fija y a tasa de interés variable o a tasa de interés indizada, ligada a la inflación o al tipo de cambio. Los valores a tasa fija pagan una tasa 
de interés que se mantiene sin cambio durante toda la vida del instrumento. Cuando los valores pagan una tasa variable, la tasa de interés cambia periódicamente y, finalmente, cuando pagan una tasa de interés indizada, ésta cambia de acuerdo con la referencia a la que se haya indizado.

d) El riesgo del emisor. La capacidad de pago del emisor puede ser un criterio de clasificación de los instrumentos de deuda. Normalmente las agencias calificadoras asignan una calificación a los emisores de instrumentos de deuda de acuerdo con su capacidad de pago.

B) De capital:

El mercado de capitales es un tipo de mercado financiero en el que se ofrecen y demandan fondos o medios de financiación a medio y largo plazo. Su principal objetivo es canalizar los recursos y el ahorro de los inversionistas, para que los emisores lleven a cabo dentro de sus empresas, operaciones de financiamiento e inversión. Frente a ellos, los mercados monetarios son los que ofrecen y demandan fondos, liquidez a corto plazo.

\section{Servicios de banca electrónica}

Éste es un servicio bancario integral que permite a los usuarios o clientes, conectarse al banco y poder realizar cualquier tipo de operación sin necesidad de acudir a la sucursal; puede efectuar operaciones vía telefónica, Internet, a través de dispositivos móviles, cajeros automáticos o pagar productos y servicios en establecimientos afiliados al sistema.

Es un servicio que permite a los clientes, realizar sus operaciones a un menor costo, de forma fácil, rápida, segura, y permite tener un manejo eficiente de tiempo y recursos. 


\section{A. Operaciones bancarias electrónicas}

Las transferencias electrónicas de fondos permiten enviar dinero a través de medios electrónicos a una cuenta de cheques o tarjeta de débito en cualquiera de las instituciones bancarias ubicadas dentro del territorio nacional. Algunas instituciones ofrecen la posibilidad de realizar pagos y depósitos en forma programada; es decir, a través del banco por Internet se pueden programar los pagos ya sea 24 o 48 horas antes. Hay que tomar en cuenta que para poder realizar esta transacción es necesario contar con la "Clabe" del beneficiario.

Para hacer la transferencia o depósito, es necesario ser cuentahabiente del banco, y la operación se puede realizar a través de:

1) Internet. Proporcionando la Clabe del destinatario, el banco realizará el cargo por el importe enviado más la comisión correspondiente. El costo de las transferencias electrónicas varían si la cuenta pertenece a una persona física o a una persona moral.

2) Ventanilla. Realizando transferencias interbancarias directamente en la ventanilla de la sucursal con cargo en la cuenta, o en tarjeta de débito, y contando con la Clabe del beneficiario. Hay que tomar en consideración el cobro de comisiones, ya que éstas varían de una institución a otra.

Para este tipo de operaciones es importante considerar lo siguiente:

- Este servicio sólo funciona con cuentas de cheques o para tarjeta de débito; no es posible realizar este tipo de transferencias de fondos a tarjetas de crédito.

- Se tiene la posibilidad de seguir realizando depósitos a través de cheques o con dinero en efectivo. 
- El servicio de transferencias electrónicas no tiene restricción en volumen e importe, así como realizar múltiples envíos.

- Este servicio permite incluir una referencia, leyenda del ordenante o motivo de pago. Esta anotación sirve para que la persona que recibe el dinero identifique quién le está depositando los recursos y el concepto.

- Para efectos de aclaraciones, el sistema de transferencias electrónicas cuenta con la referencia numérica del ordenante y la clave de rastreo.

- Para hacer uso del Servicio (TEF) es necesario contar con la Clabe, ya que sin ella no se podrán hacer transferencias interbancarias.

\section{B. Nómina electrónica}

La nueva ley de ISR señala que será obligación de los patrones expedir y entregar comprobantes fiscales a las personas que reciban pagos por prestación de un servicio; es decir, todo empleado asalariado recibirá "recibo de nómina electrónico".

De acuerdo con lo aprobado por los legisladores federales, los empleadores deberán timbrar con un proveedor autorizado de certificaciones (PAC) cada uno de los recibos de nómina que entreguen a sus trabajadores, cumpliendo los mismos requisitos que un comprobante fiscal digital por Internet, CFDI.

A partir de 2014 los recibos de nómina tendrán que emitirse en forma de CFDI ya que utilizan el mismo formato de archivo XML que se utiliza para las facturas electrónicas.

De acuerdo con la nueva Ley del Impuesto sobre la Renta, capítulo I, todo patrón deberá emitir recibos de nómina en CDFI a nombre de sus empleados, con la fecha de la erogación correspondiente y los elementos que forman parte de todo comprobante CFDI.

En un primer momento, el cambio a nómina CFDI será una carga administrativa para los patrones; sin embargo, con el tiempo 
se reflejará en una optimización de los procesos fiscales, así como de ahorro en costos.

\section{Cajeros automáticos}

Son terminales electrónicas enlazadas al sistema del banco, en las cuales se pueden realizar consultas de saldos y movimientos, así como depositar o retirar efectivo; pago de servicios, utilizando para ello una tarjeta inteligente y un código de identificación llamado NIP. Este servicio está disponible las 24 horas los 365 días del año y lo pueden utilizar tanto las personas físicas como las personas físicas con actividad empresarial.

Algunas instituciones de crédito han incorporado cajeros automáticos exclusivamente para recibir dinero.

\section{Banca telefónica}

Es un servicio que permite realizar operaciones los 365 días del año y las 24 horas al día a través de una llamada, donde una operadora o un sistema de audiorrespuesta lo atienden para efectuar las siguientes operaciones:

- Consulta de saldos, i. e. cuentas de cheques, tarjetas de crédito y débito, inversiones.

- Consulta de movimientos, cargos y abonos.

- Traspasos entre cuentas propias, cheques, tarjetas de crédito.

- Pagos de saldos a tarjetas de crédito.

- Pagos de servicios (teléfono, luz, servicio de cable...).

- Información financiera.

Actualmente este tipo de servicio ya casi no es utilizado, debido al boom que han tenido los dispositivos móviles para llevar a cabo estas operaciones. 


\section{E. Bancanet (Internet)}

Es un servicio que permite realizar operaciones todo el año a cualquier hora del día a través de una computadora conectada a Internet, y en donde se pueden realizar las siguientes operaciones:

- Consulta de saldos y movimientos.

- Traspasos entre cuentas propias.

- Inversiones.

- Pago de servicios e impuestos federales.

- Pagos a terceros.

- Pagos de saldos a tarjetas de crédito.

- Servicios (por ejemplo: solicitar estado de cuenta, cambio de NIP, etcétera).

- Información en general; por ejemplo, cotización de metales y divisas, tasas de interés, promociones, etcétera.

\section{Banca de desarrollo}

Las instituciones de crédito son entidades de la administración pública federal, con personalidad jurídica y patrimonio propios, constituidas con el carácter de sociedades nacionales de crédito, en los términos de sus correspondientes leyes orgánicas y de la Ley de Instituciones de Crédito. ${ }^{83}$

Cada una de las instituciones de banca de desarrollo además de su ley orgánica contarán con un reglamento orgánico, que establecerá las bases conforme a las cuales se regirá su organización y el funcionamiento de sus órganos. Dicho reglamento orgánico será expedido por la Secretaría de Hacienda y Crédito Público.

Cabe destacar que el reglamento orgánico y sus modificaciones deberán publicarse en el Diario Oficial de la Federación e inscribirse en el Registro Público de Comercio.

83 Artículo 30 de la Ley de Instituciones de Crédito. 
El objeto fundamental de las instituciones de banca de desarrollo abarca lo siguiente:

- Facilitar el acceso al crédito y los servicios financieros a personas físicas y morales.

- Proporcionar a personas físicas y morales asistencia técnica y capacitación en términos de sus respectivas leyes orgánicas, con el fin de impulsar el desarrollo económico.

- Procurar la sustentabilidad de la institución, mediante la canalización eficiente, prudente y transparente de recursos y la suficiencia de las garantías que se constituyan a su favor, sin que resulten excesivas.

- Realizar funciones de banca social, conforme a lo que se determine en sus respectivas leyes orgánicas.

- Crear programas y productos destinados a la atención de las áreas prioritarias para el desarrollo nacional, que promuevan la inclusión financiera de las personas físicas y morales, incluyendo en las instituciones que corresponda, a las micro, pequeñas y medianas empresas, así como a pequeños productores del campo, prestándoles servicios, ofreciendo productos, asistencia técnica y capacitación. ${ }^{84}$ Podrán fomentar el desarrollo de las instituciones pequeñas y medianas para mejorar las condiciones de competencia en el sistema financiero.

- Ofrecer servicios y productos financieros que fomenten la innovación, la creación de patentes y la generación de otros derechos de propiedad industrial. A efecto de que los innovadores y creadores a quienes les presten servicios las instituciones de banca de desarrollo preserven sus derechos, la asistencia técnica y capacitación que proporcionen dichas instituciones, en su caso, comprenderá información y apoyos para el registro de propiedad industrial y la creación de patentes. ${ }^{85}$

84 Artículo 44 bis 2 de la Ley de Instituciones de Crédito.

85 Artículo 44 bis 3 de la Ley de Instituciones de Crédito. 
A. Obligaciones de las instituciones de banca de desarrollo 86

a) Las instituciones de banca de desarrollo y los fideicomisos públicos de fomento económico proporcionarán a las autoridades y al público en general información referente a sus operaciones, así como indicadores que midan los servicios con los que cada institución y fideicomiso atiende a los sectores que establecen sus respectivas leyes orgánicas y contratos constitutivos, de acuerdo con los lineamientos que para tal efecto emita la Secretaría de Hacienda y Crédito Público, utilizando medios electrónicos, ópticos o cualquier otra tecnología que les permita dar a conocer dicha información de acuerdo con las reglas de carácter general que la Secretaría de Hacienda y Crédito Público emita para tal efecto.

b) A través de los medios electrónicos con los que cuente, dará a conocer los programas de créditos y garantías, indicando las políticas y criterios conforme a los cuales realizarán tales operaciones; los informes sobre el presupuesto de gasto corriente y de inversión; las contingencias derivadas de las garantías otorgadas por la sociedad nacional de crédito, así como las contingencias laborales, o de cualquier otro tipo que impliquen un riesgo para la institución.

c) Las instituciones de banca de desarrollo formularán anualmente sus programas operativos y financieros, sus presupuestos generales de gastos e inversiones, así como las estimaciones de ingresos. Dichos programas deberán formularse conforme a los lineamientos y objetivos del Plan Nacional de Desarrollo, así como el Programa Nacional de Financiamiento para el Desarrollo y los demás programas sectoriales del propio Plan. En el marco de los planes mencionados, cada institución de banca de de-

86 Artículo 31 de la Ley de Instituciones de Crédito. 
sarrollo deberá elaborar sus programas institucionales, que contendrán un apartado relativo a la forma en que se coordinarán con las demás instituciones de banca de desarrollo.

d) Las sociedades nacionales de crédito y los fideicomisos públicos de fomento deberán someter a la autorización de la Secretaría de Hacienda y Crédito Público, de acuerdo con las metodologías, lineamientos y mecanismos que al efecto establezca, los límites de endeudamiento neto externo e interno, financiamiento neto y los límites para el resultado de intermediación financiera, concepto que deberá contener cuando menos el déficit de operación más la constitución neta de reservas crediticias preventivas. Esta información se deberá presentar en el informe sobre la situación económica, las finanzas públicas y la deuda pública, que corresponda.

e) Promover la igualdad entre hombres y mujeres y fomentar la inclusión financiera de niños y jóvenes, adoptando una perspectiva de género en sus productos y servicios. ${ }^{87}$

f) Promover la sustentabilidad ambiental en sus programas operativos y financieros, así como incentivar la responsabilidad ambiental corporativa en ellas mismas, en los términos que establezca su consejo directivo conforme a las disposiciones jurídicas aplicables. ${ }^{88}$

La banca de desarrollo es regulada y supervisada por la Comisión Nacional Bancaria y de Valores, mediante visitas, en las cuales revisa sus sistemas de control, la calidad del servicio, el riesgos, la liquidez, etcétera.

El reglamento orgánico de cada institución es elaborado por la Secretaría de Hacienda y Crédito Público, mismo que se

87 Artículo 44 bis 4 de la Ley de Instituciones de Crédito.

88 Artículo 44 bis 5 de la Ley de Instituciones de Crédito 
publica en el Diario Oficial de la Federación y en el Registro Público de Comercio.

\section{B. Concepto}

El sector de banca de desarrollo y entidades de fomento está integrado por las sociedades nacionales de crédito, las cuales conforman el sistema de banca de desarrollo; las entidades de fomento, representadas por los fideicomisos públicos de fomento; y los organismos de fomento económico supervisados por esta Comisión. Dicho sector tiene como objeto facilitar el acceso al financiamiento a personas físicas y morales, así como proporcionarles asistencia técnica y capacitación en los términos de sus respectivas leyes orgánicas o estatutos constitutivos.

\section{Objeto}

La política de la banca de desarrollo ha perseguido los siguientes objetivos:

- Centrar la atención en la población objetivo: Pymes, pequeños y medianos productores rurales, vivienda para la población de bajos recursos, proyectos de infraestructura y municipios.

- Complementar a los intermediarios financieros privados con fondeo y garantías para generar más y mejores vehículos de canalización del crédito.

- Fomentar una mayor coordinación entre los bancos de desarrollo y otras dependencias públicas cuyos programas apoyan al financiamiento.

- Impulsar el crédito de largo plazo para apoyar la competitividad y capitalización de las unidades productivas. 
D. Nacional Financiera, S.N.C. (Nafin)

Nacional Financiera es una sociedad nacional de crédito, institución de banca de desarrollo con personalidad jurídica y patrimonio propios.

\section{Objeto}

Nafin tiene por objeto promover el ahorro y la inversión, así como canalizar apoyos financieros y técnicos al fomento industrial y, en general, al desarrollo económico nacional y regional del país.

Con el fin de fomentar el desarrollo integral del sector industrial y promover su eficiencia y competitividad, en el ejercicio de su objeto canalizará apoyos y recursos, y estará facultada para:

- Promover, gestionar y poner en marcha proyectos que atiendan necesidades del sector en las distintas zonas del país o que propicien el mejor aprovechamiento de los recursos de cada región.

- Establecer programas de financiamiento para apoyar actividades económicas que propicien la creación de empleos, en las empresas u organizaciones indígenas; que permitan la incorporación de tecnologías que les ayuden a incrementar su capacidad productiva, así como para asegurar el acceso equitativo de las mismas a los sistemas de abasto y comercialización.

- Promover, encauzar y coordinar la inversión de capitales.

- Impulsar el desarrollo tecnológico, la capacitación, la asistencia técnica y el incremento de la productividad.

- Ser agente financiero del gobierno federal en lo relativo a la negociación, contratación y manejo de créditos del exterior, cuyo objetivo sea fomentar el desarrollo económico, que se otorguen por instituciones extranjeras privadas, gubernamentales o intergubernamentales, así 
como por cualquier otro organismo de cooperación financiera internacional.

- Gestionar y, en su caso, obtener concesiones, permisos y autorizaciones para la prestación de servicios públicos vinculados con la consecución de su objeto o para el aprovechamiento de recursos naturales, que aportará a empresas que promueva. En igualdad de circunstancias gozará del derecho de preferencia frente a los particulares u otras instituciones para obtener dichos permisos, autorizaciones o concesiones, a excepción de lo que senalen las disposiciones legales aplicables.

- Realizar los estudios económicos y financieros que permitan determinar los proyectos de inversión prioritarios, a efecto de promover su realización entre inversionistas potenciales.

- Propiciar el aprovechamiento industrial de los recursos naturales inexplotados o insuficientemente explotados.

- Fomentar la reconversión industrial, la producción de bienes exportables y la sustitución eficiente de importaciones.

- Promover el desarrollo integral del mercado de valores.

- Propiciar acciones conjuntas de financiamiento y asistencia con otras instituciones de crédito, fondos de fomento, fideicomisos, organizaciones auxiliares de crédito y con los sectores social y privado.

Ser administradora y fiduciaria de los fideicomisos, mandatos y comisiones constituidos por el gobierno federal para el fomento de la industria o del mercado de valores.

\section{E. Banco Nacional de Obras y Servicios Públicos, S.N.C. (Banobras)}

El Banco Nacional de Obras y Servicios Públicos es una sociedad nacional de crédito con personalidad jurídica y patrimonio propios, que presta el servicio público de banca y crédito con sujeción a los objetivos y prioridades del Plan Nacional de Desarrollo, y del Programa Nacional de Financiamiento del De- 
sarrollo, de acuerdo con los programas sectoriales y regionales, así como a los planes estatales y municipales, para promover y financiar tanto a las actividades como a los sectores que le son encomendados en su ley orgánica.

\section{Objeto}

Banobras tiene por objeto financiar o refinanciar proyectos de inversión pública o privada en infraestructura y servicios públicos, así como coadyuvar al fortalecimiento institucional de los gobiernos federal, estatal y municipal, con el propósito de contribuir al desarrollo sustentable del país.

La institución, con el fin de procurar la eficiencia y competitividad de los sectores encomendados en el ejercicio de su objeto, está facultada para:

- Coadyuvar en el ámbito de su competencia, al fortalecimiento del pacto federal y del municipio libre, en los términos del artículo 115 constitucional, para lograr el desarrollo equilibrado del país y la descentralización de la vida nacional con la atención eficiente y oportuna de las actividades regional o sectorialmente prioritarias, así como impulsar la inversión y el financiamiento privado en infraestructura y servicios públicos.

- Promover y financiar la dotación de infraestructura, servicios públicos, equipamiento urbano, así como la modernización y fortalecimiento institucional en estados y municipios.

- Financiar y proporcionar asistencia técnica a los municipios para la formulación, administración y ejecución de sus planes de desarrollo urbano y para la creación y administración de reservas territoriales y ecológicas, así como estructurar y coordinar proyectos de inversión.

- Promover programas de financiamiento para ampliar la cobertura de los servicios públicos y generar la infraes- 
tructura productiva necesaria para impulsar el desarrollo regional de las zonas indígenas.

- Otorgar asistencia técnica y financiera para la mejor utilización de los recursos crediticios y el desarrollo de las administraciones locales, financiar proyectos de infraestructura y servicios públicos. La institución no podrá administrar obras y servicios públicos realizados con sus financiamientos.

- Apoyar los programas de vivienda y el aprovechamiento racional del suelo urbano.

- Financiar el desarrollo de los sectores de comunicaciones y transportes.

- Propiciar acciones conjuntas de financiamiento y asistencia con otras instituciones de crédito, fondos de fomento, fideicomisos, organizaciones auxiliares del crédito y con los sectores social y privado.

\section{F. Banco Nacional de Comercio Exterior, S.N.C. (Bancomext)}

El Banco Nacional de Comercio Exterior es una sociedad nacional de crédito, institución de banca de desarrollo con personalidad jurídica y patrimonio propios.

\section{Objeto}

Bancomext tiene por objeto como institución de banca de desarrollo, financiar el comercio exterior del país, así como participar en la promoción de dicha actividad.

La institución, con el fin de procurar la eficiencia y competitividad del comercio exterior comprendiendo la preexportación, exportación, importación y sustitución de importación de bienes y servicios, en el ejercicio de su objeto, estará facultado para: 
- Conceder apoyos financieros.

- Otorgar garantías de crédito y las usuales en el comercio exterior.

- Proporcionar información y asistencia financiera a los productores, comerciantes, distribuidores y exportadores, en la colocación de artículos y prestación de servicios en el mercado internacional.

- Promover las exportaciones mexicanas, podrá participar en el capital social de empresas de comercio exterior, consorcios de exportación y empresas que otorguen seguro de crédito al comercio exterior. Asimismo, podrá participar en el capital social de sociedades de inversión y sociedades operadoras de éstas.

- Promover, encauzar y coordinar la inversión de capitales a las empresas dedicadas a la exportación.

- Otorgar financiamiento a los exportadores indirectos y en general al aparato productivo exportador, a fin de optimizar la cadena productiva de bienes o servicios exportables, así como coadyuvar en el fomento del comercio exterior del país y realizar todos los actos y gestiones que permitan atraer inversión extranjera al país.

- Promover las exportaciones mexicanas, podrá otorgar apoyos financieros a las empresas comercializadoras de exportación, consorcios y entidades análogas de comercio exterior.

- Propiciar acciones conjuntas de financiamiento y asistencia en materia de comercio exterior con otras instituciones de crédito, fondos de fomento, fideicomisos, organizaciones auxiliares de crédito y con los sectores social y privado.

- Propiciar acciones conjuntas de financiamiento y asistencia para las personas, empresas y organizaciones productivas y de comercialización, en pueblos y comunidades indígenas, en materia de comercio exterior con otras 
instituciones de crédito, fondos de fomento, fideicomisos, organizaciones auxiliares de crédito y con los sectores social y privado.

- Ser agente financiero del gobierno federal en lo relativo a la negociación, contratación y manejo de créditos del exterior, ya sea que éstos sean otorgados por instituciones del extranjero, privadas, gubernamentales e intergubernamentales.

- Participar en la negociación y, en su caso, en los convenios financieros de intercambio compensado o de créditos recíprocos, que señale la Secretaría de Hacienda y Crédito Público.

- Estudiar políticas, planes y programas en materia de fomento al comercio exterior y su financiamiento, y someterlos a la consideración de las autoridades competentes.

- Fungir como órgano de consulta de las autoridades competentes, en materia de comercio exterior y su financiamiento.

- Participar en las actividades inherentes a la promoción del comercio exterior, tales como difusión, estudio de productos y servicios exportables, sistemas de venta, apoyo a la comercialización y organización de productores, comerciantes, distribuidores y exportadores.

- Opinar, a solicitud que le formulen directamente las autoridades competentes, sobre tratados y convenios que el país proyecte celebrar con otras naciones, en materia de comercio exterior y su financiamiento.

- Participar en la promoción de la oferta exportable.

- Podrá actuar como conciliador y árbitro en las controversias en que intervienen importadores y exportadores con domicilio en la República mexicana. 


\section{G. Sociedad Hipotecaria Federal, S.N.C. (SHF)}

La Sociedad Hipotecaria Federal es una sociedad nacional de crédito, institución de banca de desarrollo con personalidad jurídica y patrimonio propios.

\section{Objeto}

Impulsar el desarrollo de los mercados primario y secundario de crédito a la vivienda, mediante el otorgamiento de crédito y garantías destinadas a la construcción, adquisición y mejora de vivienda, preferentemente de interés social, así como al incremento de la capacidad productiva y el desarrollo tecnológico, relacionados con la vivienda.

Asimismo, podrá garantizar financiamientos relacionados con el equipamiento de conjuntos habitacionales.

Para el logro de sus objetivos, la SHF podrá llevar a cabo los actos siguientes:

- Aceptar préstamos y créditos.

- Emitir bonos bancarios.

- Constituir depósitos en instituciones de crédito y en entidades financieras del exterior.

- Operar con divisas y valores, incluyendo aquellos respaldados por garantías otorgadas por la sociedad o seguros otorgados por aseguradoras en las que participe esta última.

- Garantizar créditos y valores relacionados con financiamientos a la vivienda, otorgados o emitidos por entidades financieras, e invertir en esos valores.

- Otorgar créditos relacionados con la vivienda, con el fin de impulsar el desarrollo de algún segmento de los mercados primario y secundario de crédito a la vivienda o de procurar la estabilidad de dichos mercados conforme a los criterios que defina su consejo directivo. 
- Prestar servicios de consultoría.

- Celebrar contratos para cubrir, total o parcialmente, los riesgos que asuma la sociedad por las operaciones de prestar servicios de consultoría.

- Promover esquemas para constituir pagos iniciales o enganches destinados a la adquisición de vivienda.

- Realizar avalúos que tendrán la misma fuerza probatoria que las leyes asignan a los efectuados por corredor público o perito.

- Practicar operaciones de fideicomiso y llevar a cabo mandatos y comisiones relativos a su fin, cuando por ley se le asigne a la sociedad esa encomienda; cuando se trate de actos que coadyuven a la consecución de su objetivo o bien cuando la propia sociedad constituya fideicomisos para cumplir obligaciones laborales a su cargo.

- Actuar como representante común de tenedores de títulos de crédito representativos de financiamiento a la vivienda.

- Realizar aportaciones para la constitución de instituciones de seguros de los ramos de crédito a la vivienda y garantía financiera o invertir en el capital social de éstas.

- Invertir, con la previa autorización de la Secretaría de Hacienda y Crédito Público, en el capital social de las empresas que le presten servicios complementarios o auxiliares en la administración o en la realización del objeto de la propia sociedad o realizar aportaciones para la constitución de este tipo de empresas, en cuyo caso éstas no serán consideradas de participación estatal y, por lo tanto, no estarán sujetas a las disposiciones aplicables a las entidades de la administración pública federal paraestatal, así como contratar sus servicios sin que resulte aplicable para tal efecto la Ley de Adquisiciones, Arrendamientos y Servicios del Sector Público.

- Las demás operaciones a que se refiere la Ley de Instituciones de Crédito, así como las análogas y conexas que autorice la Secretaría de Hacienda y Crédito Público. 
H. Banco del Ahorro Nacionaly Servicios Financieros, S.N.C. (Bansefi)

El Banco del Ahorro Nacional y Servicios Financieros es una sociedad nacional de crédito, institución de banca de desarrollo con personalidad jurídica y patrimonio propios.

\section{Objeto}

Bansefi tiene por objeto promover el ahorro, el financiamiento y la inversión entre los integrantes del sector de ahorro y crédito popular, ofrecer instrumentos y servicios financieros entre los mismos, así como canalizar apoyos financieros y técnicos necesarios para fomentar el hábito del ahorro y el sano desarrollo del sector y en general, al desarrollo económico nacional y regional del país.

La institución, con el fin de fomentar el desarrollo integral del sector y promover su eficiencia y competitividad, en el ejercicio de su objeto estará facultada para:

- Promover, gestionar y financiar proyectos que atiendan las necesidades de los organismos de integración, de las entidades de ahorro y crédito popular, así como de las personas morales y grupos de personas físicas a que se refiere la Ley de Ahorro y Crédito Popular, y que le permitan cumplir con su objeto, en las distintas zonas del país y que propicien el mejor aprovechamiento de los recursos de cada región.

- Promover, encauzar y coordinar la inversión de capitales en el sector.

- Promover el desarrollo tecnológico, la capacitación, la asistencia técnica y el incremento de la productividad de los organismos de integración, de las entidades de ahorro y crédito popular, así como de las personas morales 
y grupos de personas físicas a que se refiere la Ley de Ahorro y Crédito Popular.

- Ser agente financiero del gobierno federal en lo relativo a la negociación, contratación y manejo de créditos del exterior, cuyo objetivo sea fomentar el desarrollo del sector, que se otorguen por instituciones extranjeras privadas, gubernamentales o intergubernamentales, así como por cualquier otro organismo de cooperación financiera internacional. No se incluyen en esta disposición los créditos para fines monetarios.

- Gestionar y, en su caso, obtener concesiones, permisos y autorizaciones para la prestación de servicios vinculados con la consecución de su objeto.

- Realizar los estudios económicos, sociales y financieros necesarios para el desarrollo del sector.

- Propiciar acciones conjuntas de financiamiento y asistencia con otras instituciones de crédito, fondos de fomento, fideicomisos, organizaciones auxiliares del crédito, con los sectores indígena, social y privado y con los organismos de integración y las entidades de ahorro y crédito popular.

- Ser administradora y fiduciaria de fideicomisos, mandatos y comisiones que se constituyan para el adecuado desempeño de su objeto.

- Promover, gestionar y financiar toda clase de proyectos, operaciones y actividades que atiendan las necesidades de servicios financieros, tecnológicos, de capacitación, de asesoría, de administración de riesgos financieros, entre otros, de los organismos de integración y de las entidades de ahorro y crédito popular, así como de las personas morales y grupos de personas físicas a que se refiere la Ley de Ahorro y Crédito Popular.

- Participar en las actividades inherentes a la promoción y conformación del sector. 
- Diseñar y ejecutar programas que promuevan el ahorro y la inversión dentro de las comunidades indígenas. La institución deberá contar con la infraestructura necesaria para la adecuada prestación de servicios y realización de operaciones, en las distintas regiones del país y en su caso, en el extranjero.

I. Banco Nacional del Ejército, Fuerza Aérea y Armada, S.N.C. (Banjercito)

El Banco Nacional del Ejército, Fuerza Aérea y Armada es una sociedad nacional de crédito, con personalidad jurídica y patrimonio propios, que presta el servicio público de banca y crédito con sujeción a los objetivos y prioridades del Plan Nacional de Desarrollo, y en especial del Programa Nacional de Financiamiento del Desarrollo, para promover y financiar las actividades y sectores que le son encomendados en su ley orgánica.

\section{Objeto}

Banjercito tiene por objeto otorgar apoyos financieros a los miembros del ejército, fuerza aérea y armada mexicanos.

La institución, con el fin de procurar el desarrollo y competitividad del sector encomendado en el ejercicio de su objeto, está facultada para:

- Apoyar financieramente a los miembros de las fuerzas armadas, para el ejercicio de sus profesiones o actividades productivas, no incompatibles con la función militar.

- Actuar como agente financiero de las empresas y sociedades con las que opere.

- Administrar los fondos de ahorro y de trabajo de los militares. 
- Promover asesoría técnica a favor de las entidades señaladas en los dos puntos anteriores, con objeto de proporcionar el incremento de la productividad.

- Propiciar acciones conjuntas de financiamiento y asistencia con otras instituciones de crédito, fondos de fomento, fideicomisos, organizaciones auxiliares de crédito y con los sectores social y privado.

En el ejercicio de sus atribuciones, Banjercito ajustará sus programas a las políticas financieras que establezca el gobierno federal y se coordinará en sus actividades con las entidades que tengan a su cargo la elaboración y ejecución de dicha política. 


\section{SECTOR ORGANIZACIONES Y ACTIVIDADES AUXILIARES DEL GRÉDITO}

\section{ORGANIZACIONES AUXILIARES DE CRÉDITO}

Entidades sujetas a la autorización por parte del gobierno federal a través de la SHCP, de acuerdo con los artículos 3o. y 4o. de la Ley General de Organizaciones y Actividades Auxiliares de Crédito, se consideran las siguientes:

- Almacenes generales de depósito.

- Uniones de crédito (reguladas por la Ley de Uniones de Crédito).

\section{SOGIEDADES FINANGIERAS DE OBJETO LIMITADO}

\section{Concepto}

Instituciones financieras autorizadas por la Secretaría de Hacienda y Crédito Público, reglamentadas por Banco de México y supervisada por la Comisión Nacional Bancaria y de Valores.

Tienen como objetivo otorgar créditos o financiamientos a sectores o actividades específicos o aquellos que no han tenido acceso a créditos ofrecidos por los bancos.

\section{Su función dentro del sistema financiero mexicano}

Las sociedades financieras de objeto limitado (Sofoles) son sociedades anónimas autorizadas por la Secretaría de Hacienda 
y Crédito Público, que actúan como intermediario financiero en las ramas: hipotecaria, mediana industria y bienes de consumo. Captan recursos y otorgan créditos de forma limitada, a una determinada actividad o sector; juegan un papel relevante en la oferta de crédito hipotecario, al proveer el nueve por ciento del crédito total a este sector y representar un tercio de la cantidad que proveen los bancos.

Las Sofoles han logrado expandir el crédito gracias a tres fuentes de financiamiento principalmente: los créditos obtenidos de la Sociedad Hipotecaria Federal, SHF, la emisión de papel comercial y la bursatilización de hipotecas. Los eventos recientes a nivel internacional demostraron que durante periodos de inestabilidad e incertidumbre financiera los inversionistas pueden requerir mayores primas por el riesgo o incluso reducir el financiamiento. En estos casos, la naturaleza de corto plazo de la deuda comercial y otros pasivos y la dificultad para emitir otros valores puede provocar dificultades de liquidez.

Las bursatilizaciones de hipotecas juegan un papel muy importante en el manejo de liquidez de las Sofoles, ya que permiten transformar activos de largo plazo en activos líquidos para generar nuevas hipotecas o hacer frente, en caso de ser necesario, a pasivos de corto plazo.

Los préstamos bancarios y de otros organismos representan la mayor proporción de los pasivos de las Sofoles, con sesenta por ciento. El mayor prestamista es la SHF y la mayoría de sus préstamos son de largo plazo. La banca múltiple realiza en su mayoría préstamos de corto plazo.

Para resumir, podemos llamar a las Sofoles bancos especializados, ya que prestan solamente para un sector, construcción, automotriz, o actividad; por ejemplo, consumo a través de tarjetas de crédito, sólo que en lugar de recibir depósitos para captar recursos tienen que obtener dinero mediante la colocación de valores o solicitando créditos. Su principal producto es el otorgar créditos para la adquisición de bienes específicos, como autos o casas u operar tarjetas de crédito. Son sociedades que están 
autorizadas por la SHCP para captar recursos provenientes de la colocación de instrumentos inscritos en el Registro Nacional de Valores e Intermediarios y otorgar crédito para determinada actividad o sector. De conformidad con las autorizaciones otorgadas por la Secretaría de Hacienda y Crédito Público, en la actualidad los sectores atendidos por las Sofoles son: agroindustrial, consumo, pequeñas y medianas empresas, hipotecario y automotriz.

\section{Operaciones}

Las Sofoles pueden realizar operaciones activas y pasivas, que por su clasificación encuentran similitud con la forma de catalogar los registros contables de activo y pasivo en un balance contable Adicionalmente hay una clasificación a la que se han referido como operaciones de servicios, complementarias o neutras.

\section{A. Operaciones pasivas}

Las operaciones pasivas implican captación de recursos por parte de la Sofol; es la forma en como ésta se fondea para poder a su vez cumplir con su objeto social. Son tres formas en las que las Sofoles pueden fondearse:
a) Colocación de valores.
b) Fondeo de otras entidades financieras del país y del ex- terior.
c) Aportaciones de sus socios.

\section{B. Operaciones activas}

Las operaciones activas de las Sofoles implican el otorgamiento de créditos, que en cumplimiento con su objeto limitado a terceros, a su vez devolverán el crédito otorgado con intereses por el uso del mismo. 


\section{Operaciones complementarias}

Dentro de las operaciones complementarias de las Sofoles están las de invertir sus recursos líquidos en instrumentos de captación de entidades financieras, así como en instrumentos de deuda de fácil realización; adquirir los bienes muebles e inmuebles necesarios para la realización de su objeto; las analogías y conexas que autorice el Banco de México, y las que en su carácter de fiduciaria pudieran realizar.

\section{Otros ingresos financieros}

Adquirir los bienes muebles e inmuebles necesarios para la realización de su objetivo, las análogas y conexas que autorice el Banco de México, y las que en su carácter de fiduciaria puedan realizar.

E. Incorporación de una sociedad a un grupo financiero

Los grupos están integrados por una sociedad controladora y por algunas de las sociedades financieras siguientes:

\section{Almacenes Generales DE DePÓSito}

\section{Objeto}

Tiene por objeto el almacenamiento, guarda o conservación de bienes o mercancías y la expedición de certificados de depósitos y bonos de prenda. Sólo los almacenes generales de depósito están facultados para expedir certificados de depósito y bonos en prenda. 


\section{Actividades}

- Transformar las mercancías.

- Certificar la calidad de sus mercancías y bienes depositados.

- Empacar los bienes y mercancías.

3. Tipos de almacenes

Los almacenes generales de depósito podrán ser de tres clases:

1) Los que se destinen a recibir en depósito bienes o mercancías de cualquier clase y realicen las demás actividades a que se refiere esta ley, a excepción del régimen de depósito fiscal y otorgamiento de financiamientos.

2) Los que además de estar facultados en los términos señalados en la fracción anterior lo estén también para recibir mercancías destinadas al régimen de depósito fiscal.

3) Los que además de estar facultados en los términos de alguna de las fracciones anteriores otorguen financiamientos conforme a lo previsto en esta ley, debiendo sujetarse a los requerimientos mínimos de capitalización que al efecto establezca la Secretaría de Hacienda y Crédito Público, mediante disposiciones de carácter general.

\section{ACTIVIDADES AUXILIARES DEL CRÉDITO}

Las actividades auxiliares del crédito son:

- La compraventa habitual y profesional de divisas;

- La realización habitual y profesional de operaciones de crédito, arrendamiento financiero o factoraje financiero, y

- Transmisión de fondos. 


\section{Centro cambiario}

Son sociedades anónimas organizadas de conformidad con lo dispuesto en la LGSM, que se encuentran registradas ante la GNBV; las operaciones que podrán realizar son las siguientes:

- Compra y venta de billetes, así como piezas acuñadas y metales comunes, con curso legal en el país de emisión, hasta por un monto no superior al equivalente en moneda nacional a diez mil dólares de los Estados Unidos de América por cada cliente en un mismo día.

- Compra y venta de cheques de viajero denominados en moneda extranjera, hasta por un monto no superior al equivalente en moneda nacional a diez mil dólares de los Estados Unidos de América por cada cliente en un mismo día.

- Compra y venta de piezas metálicas acuñadas en forma de moneda, hasta por un monto no superior al equivalente en moneda nacional a diez mil dólares de los Estados Unidos de Norte América por cada cliente en un mismo día.

- Compra de documentos a la vista denominados y pagaderos en moneda extranjera, a cargo de entidades financieras, hasta por un monto no superior al equivalente a diez mil dólares de los Estados Unidos por cada cliente en un mismo día. Al respecto, los centros cambiarios sólo podrán vender estos documentos a las instituciones de crédito y casas de cambio.

\section{Sociedad financiera de objeto múltiple}

Es la sociedad anónima que cuenta con un registro vigente ante la Comisión Nacional para la Protección y Defensa de los Usuarios de Servicios Financieros; su objeto social principal es la realización habitual y profesional de una o más de las actividades 
de otorgamiento de crédito, arrendamiento financiero o factoraje financiero; deberán agregar a su denominación social la expresión "sociedad financiera de objeto múltiple" o su acrónimo "Sofom", seguido de las palabras "entidad regulada" o su abreviatura "E. R." o "entidad no regulada" o su abreviatura "E. N. R.".

\section{Obligaciones de las sociedades financieras de objeto}

múltiple en las operaciones de crédito, arrendamiento financiero y factoraje financiero

- Informar a sus clientes previamente sobre la contraprestación; monto de los pagos parciales, la forma y periodicidad para liquidarlos; cargas financieras; accesorios; monto y detalle de cualquier cargo, si lo hubiera; número de pagos a realizar, su periodicidad; en su caso, el derecho que tiene a liquidar anticipadamente la operación y las condiciones para ello, y los intereses, incluidos los moratorios, forma de calcularlos y el tipo de tasa y, en su caso, tasa de descuento.

- De utilizarse una tasa fija, también se informará al cliente el monto de los intereses a pagar en cada periodo. De utilizarse una tasa variable, se informará al cliente sobre la regla de ajuste de la tasa, que no podrá depender de decisiones unilaterales de la sociedad financiera de objeto múltiple respectiva, sino de las variaciones que registre una tasa de interés representativa del costo de la operación al cliente, la cual deberá ser fácilmente verificable por el cliente.

- Informar al cliente el monto total a pagar por la operación de que se trate, en su caso, número y monto de pagos individuales, los intereses, comisiones y cargos correspondientes, incluidos los fijados por pagos anticipados o por cancelación; proporcionándole debidamente desglosados los conceptos correspondientes. 


\section{UNIONES DE GRÉDITO}

Las "uniones de crédito" son instituciones financieras reguladas y organizadas como sociedades anónimas, que se encuentran bajo la supervisión y vigilancia de la Comisión Nacional Bancaria y de Valores, CNBV, y están constituidas con el propósito de ofrecer acceso al financiamiento a sus socios. Asimismo, ofrecen condiciones favorables para ahorrar, recibir préstamos y servicios financieros.

\section{Objeto y naturaleza}

Las uniones de crédito están autorizadas para realizar operaciones exclusivamente con sus socios, y para ser socio se debe cumplir con los requisitos establecidos en la Ley de Uniones de Crédito y adquirir determinado número de acciones de la unión de crédito que representen el valor equivalente a 2,500 unidades de inversión.

Existen uniones de crédito de diferentes sectores: curtidores, pescadores, ganaderos, industriales, campesinos, comerciantes, etcétera; sin embargo, también existen las del "sector social", que son las que están orientadas a atender al sector económico que por sus condiciones sociales, económicas y geográficas no pueden acceder a las instituciones financieras tradicionales, y las "mixtas", que atienden diversos sectores.

\section{Actividades}

- Facilitar el uso del crédito a sus socios y prestar su garantía o aval, en los créditos que contraten sus socios.

- Recibir préstamos exclusivamente de sus socios, de instituciones de crédito, de seguros y de fianzas del país o de entidades financieras del exterior, así como de sus proveedores. 
- Practicar con sus socios, operaciones de descuento, préstamo y crédito de toda clase.

- Recibir de sus socios, depósitos de dinero para el exclusivo objeto de prestar servicios de caja, cuyos saldos podrá depositar la unión en instituciones de crédito o invertirlos en valores gubernamentales.

- Promover la organización y administrar empresas industriales o comerciales, para lo cual podrán asociarse con terceras personas.

- Encargarse de la compra y venta de los frutos o productos obtenidos o elaborados por sus socios o por terceros.

- Comprar, vender y comercializar insumos, materias primas, mercancías y artículos diversos, así como alquilar bienes de capital necesarios para la explotación agropecuaria o industrial, por cuenta de sus socios o de terceros.

- Encargarse, por cuenta propia, de la transformación industrial o del beneficio de los productos obtenidos o elaborados por sus socios.

\section{CASAS DE CAMBIO: GOMPRAVENTA HABITUAL Y PROFESIONAL DE DIVISAS}

Las casas de cambio son sociedades anónimas que realizan en forma habitual y profesional, operaciones de compra, venta y cambio de divisas, incluyendo las que se lleven a cabo mediante transferencias o transmisión de fondos, con el público dentro del territorio nacional, autorizadas por la Secretaría de Hacienda y Crédito Público, reglamentadas en su operación por el Banco de México y supervisadas por la Comisión Nacional Bancaria y de Valores.

\section{Objeto y naturaleza}

Las casas de cambio se conceptúan formal y legalmente como actividades auxiliares del crédito y se rigen bajo la Ley General de Organizaciones y Actividades Auxiliares del Crédito. 
Las casas de cambio podrán determinar libremente, en función de sus costos y políticas, el importe de las contraprestaciones que cobrarán por el servicio correspondiente a la persona por cuenta de que reciban los pagos. En ningún caso podrán cobrar comisiones o cuotas al público por la recepción de dichos pagos.

Las casas de cambio podrán pactar que, en la realización de sus operaciones de compraventa, las divisas y su contravalor se entreguen diferidamente, en cuyo caso la liquidación deberá realizarse a más tardar el segundo día hábil bancario siguiente a aquel en que se contrate la operación.

Así mismo, tienen la facultad de realizar en forma directa la distribución de acciones de sociedades de inversión, bajo el amparo del artículo 40, párrafo tercero, de la Ley de Sociedades de Inversión, publicada en el Diario Oficial de la Federación el 4 de junio de 2001.

\section{Actividades}

Las operaciones correspondientes se mencionan a continuación:

- Compra y venta de billetes, así como piezas acuñadas y metales comunes, con curso legal en el país de emisión. Compra y venta de cheques de viajero denominados en moneda extranjera.

- Compra y venta de piezas metálicas acuñadas en forma de moneda.

- Compra de documentos a la vista denominados y pagaderos en moneda extranjera.

- Compra en firme o cobranza de documentos a la vista denominados y pagaderos en moneda extranjera, a cargo de entidades financieras, sin límite por documento. Asimismo, podrán celebrar tales operaciones con giros, 
órdenes de pago y otros documentos a la vista denominados y pagaderos en moneda extranjera.

- Venta de documentos a la vista denominados y pagaderos en moneda extranjera que dichas casas de cambio expidan a cargo de instituciones de crédito del país, sucursales y agencias en el exterior de estas últimas, o bancos del exterior.

- Compra y venta de divisas mediante transferencias de fondos sobre cuentas bancarias, es decir, es cuando se realiza una transferencia de fondos a cuentas de terceros.

- Enviar y recibir transferencias de fondos en moneda nacional o en divisas, dentro y fuera del territorio nacional.

- Recibir pagos de servicios por cuenta de terceros, en moneda nacional o en divisas, siempre que las casas de cambio no asuman obligaciones directas o contingentes.

\section{La transmisión de fondos}

Se requerirá autorización de la Secretaría de Hacienda y Crédito Público para realizar, en forma habitual y profesional, operaciones de compra, venta y cambio de divisas, incluyendo las que se lleven a cabo mediante transferencia o transmisión de fondos, con el público dentro del territorio nacional, salvo en los casos previstos en la Ley.

Para efectos de lo previsto en la LGOAAG y en las disposiciones que de ésta emanen, se entenderá por transmisor de dinero, fondos, exclusivamente a las sociedades anónimas y sociedades de responsabilidad limitada organizadas de conformidad con lo dispuesto en la Ley General de Sociedades Mercantiles que, entre otras actividades, y de manera habitual y a cambio del pago de una contraprestación, comisión, beneficio o ganancia, recibe en el territorio nacional derechos o recursos en moneda nacional o divisas, directamente en sus oficinas o por cable, facsímil, servicios de mensajería, medios electrónicos, transferencia electrónica 
de fondos o por cualquier vía, para que de acuerdo con las instrucciones del remisor los transfiera al extranjero, a otro lugar dentro del territorio nacional o para entregarlos en el lugar en el que sean recibidos, al beneficiario designado. Adicionalmente, podrán actuar como transmisores de dinero, las dependencias y entidades de la administración pública federal que conforme a las disposiciones que las regulan lleven a cabo las operaciones de transmisión de derechos o recursos en moneda nacional o divisas. 
Capítulo SÉPtimo

SECTOR SEGUROS Y FIANZAS

\section{INSTITUCIONES DE SEGUROS Y DE FIANZAS}

\section{Concepto}

La institución de seguros es la sociedad anónima autorizada por la Secretaría de Hacienda y Crédito Público para organizarse y operar sobre distintos ramos, ${ }^{89}$ como lo son: 1) vida; 2) accidentes y enfermedades, en alguno o algunos de los ramos siguientes: a) accidentes personales; $b$ ) gastos médicos, y c) salud; 3) daños, en alguno o algunos de los ramos siguientes: a) responsabilidad civil y riesgos profesionales; $b$ ) marítimo y transportes; $c$ ) incendio; $d$ ) agrícola y de animales; $e$ ) automóviles; $f$ ) crédito; $g$ ) caución; $h$ ) crédito a la vivienda; $\imath$ ) garantía financiera; $j$ ) riesgos catastróficos; $k$ ) diversos, y los especiales que declare la $\mathrm{SHCP}^{90}$ (éste se presenta en las instituciones de fianzas cuando alguno de sus subramos adquiera una importancia tal que amerite considerarlo como ramo independiente, y únicamente la SHCP podrá declararlo como ramo especial). ${ }^{91}$

Estas instituciones podrán realizar el reaseguro respecto de las operaciones y ramos comprendidos en su autorización.

Las instituciones de fianzas son sociedades anónimas autorizadas por la SHCP, aunque en este caso el objeto es el otorga-

89 Artículo 2o., fracción XVI, Ley de Instituciones de Seguros y de Fianzas.

90 Ibidem, artículo 25.

91 Ibidem, artículo 37. 
miento de fianzas a título oneroso, ${ }^{92}$ a las instituciones que sean autorizadas para practicar operaciones de reafianzamiento, y a las instituciones de seguros que operen el ramo de caución autorizadas para otorgar fianzas. Los ramos y subramos de estas instituciones son: 1) fianzas de fidelidad, en alguno o algunos de los subramos siguientes: $a$ ) individuales, y b) colectivas; 2) fianzas judiciales, en alguno o algunos de los subramos siguientes: a) judiciales penales; b) judiciales no penales, y c) judiciales que amparen a los conductores de vehículos automotores; 3) fianzas administrativas, en alguno o algunos de los subramos siguientes: $a$ ) obra; $b$ ) proveeduría; $c$ ) fiscales; $d$ ) arrendamiento, y e) otras fianzas administrativas; 4) fianzas de crédito, en alguno o algunos de los subramos siguientes: $a$ ) suministro; $b$ ) compraventa, y $c$ ) otras fianzas de crédito, y; 5) fideicomisos de garantía, en alguno o algunos de los subramos siguientes: a) relacionados con pólizas de fianza, y $b$ ) sin relación con pólizas de fianza. ${ }^{93}$

Las instituciones de fianzas podrán realizar el reafianzamiento respecto de los ramos y subramos comprendidos en su autorización, con excepción de los fideicomisos de garantía.

\section{Agentes de seguros y de fianzas}

Con respecto a los agentes de seguros y de fianzas, la LISF los considera como personas físicas o morales que intervengan en la contratación de seguros mediante el intercambio de propuestas y aceptación de las mismas, comercialización y asesoramiento para celebrarlos, para conservarlos o modificarlos, según la mejor conveniencia de los contratantes. ${ }^{94}$

Se consideran agentes de fianzas a las personas físicas o morales que intervengan en la contratación de fianzas median-

\footnotetext{
92 Ibidem, artículo 2o., fracción XVII.

93 Ibidem, artículo 36.

94 Ibidem, artículo 91.
} 
te el intercambio de propuestas y aceptación de las mismas, comercialización y asesoramiento para contratarlas, conservarlas o modificarlas, según la mejor conveniencia de las partes. ${ }^{95}$ Para que estos puedan operar y celebrar contratos a nombre y por cuenta de una institución de seguros o fianzas necesitan autorización de la CNSF. ${ }^{96}$

Las instituciones sólo podrán pagar comisiones y cualquier otra compensación por la contratación de seguros o de fianzas, a agentes de seguros o a agentes de fianzas, sobre las primas que efectivamente hayan ingresado a la institución de que se trate. ${ }^{97}$

Los agentes de seguros y fianzas deberán proporcionar información de manera amplia y detallada sobre el alcance real de la cobertura del seguro, así como sobre la forma de conservarla o darla por terminada. Asimismo, proporcionarán a la institución de seguros, la información precisa y relevante que sea de su conocimiento relativa al riesgo cuya cobertura se proponga. ${ }^{98}$

Los agentes sólo podrán cobrar primas contra el recibo expedido por las instituciones, por lo que les está prohibido recibir anticipos o pagos de primas con recibos distintos. Las primas así cobradas se entenderán recibidas directamente por las instituciones. ${ }^{99}$

\section{Otras entidades financieras}

\section{A. Entidades auxiliares de los intermediarios financieros}

Se trata de entidades cuya labor va orientada a facilitar o complementar la operativa de los intermediarios financieros.

\footnotetext{
95 Ibidem, artículo 92.

96 Ibidem, artículo 93.

97 Ibidem, artículo 101.

98 Ibidem, artículo 96.

99 Ibidem, artículo 99.
} 
B. Sociedades prestadoras de servicios e inmobiliarias

\section{a. Concepto}

Inmobiliarias son las personas morales propietarias de bienes destinados a oficinas de la sociedad controladora o de los demás integrantes del grupo financiero.

Prestadoras de servicio son las empresas que presten servicios complementarios o auxiliares a la propia sociedad controladora o a los demás integrantes del grupo financiero.

\section{b. Objeto}

La sociedad prestadora de servicios y las sociedades inmobiliarias tienen como objetivo general apoyar a los grupos financieros con la carga administrativa de estos servicios.

\section{Sociedades de información crediticia}

\section{A. Antecedentes}

En 1996 surge Trans Union de México, S. A., buró de personas físicas, como la primera sociedad de información crediticia en México autorizada por la SHCP, con el fin de proporcionar información del comportamiento crediticio de personas físicas. Tiene como socios a la Banca Comercial, a Trans Union Co., buró crediticio con experiencia en manejo de registros de crédito, y Fair Isaac Co., empresa con experiencia en modelos de análisis de riesgo.

En 1998 se incorpora Dun \& Bradstreet de México, S. A., sociedad de información crediticia, buró de personas morales, con el fin de proporcionar información sobre el comportamiento crediticio de personas morales, y físicas con actividad empresa- 
rial. Tiene como socios a la banca comercial, a Trans Union Co. y a Dun \& Bradstreet Co., con experiencia a nivel mundial en la evaluación de empresas.

En junio de 2005 se autoriza a Círculo de Crédito, S. A. de C. V., sociedad de información crediticia, con el fin de proporcionar información sobre el comportamiento de crédito del segmento no bancarizado del país. Tiene como socios a Banca Afirme, Chedraui, Coppel y Grupo Elektra.

\section{B. Concepto}

Los burós de crédito son instituciones financieras, autorizadas por la SHCP, previa opinión del Banco de México y de la GNBV. Oficialmente este tipo de entidades son conocidas como sociedades de información crediticia, en adelante SIC, y son organizaciones que proporcionan servicios de recopilación, manejo y entrega o envío de información relativa al historial crediticio de personas físicas y morales.

\section{G. Constitución}

Las sociedades de información crediticia se crean mediante autorización de la SHCP, escuchando la opinión de la Comisión y del Banco de México, una vez que hubiera cumplido con todos los requisitos que marca la Ley para Regular a las Sociedades de Información Crediticia.

El gobierno federal podrá contar con una entidad paraestatal constituida como sociedad de información crediticia, que forme parte del sistema financiero, sin que al efecto se requiera la autorización prevista en el artículo 6o. de esta Ley. No obstante, en todo momento deberá sujetarse a las disposiciones de este ordenamiento y las demás que resulten aplicables por la función que realice. 


\section{Objeto}

Su objetivo es contribuir al desarrollo económico del país ofreciendo servicios que promueven minimizar el riesgo crediticio, al proporcionar información que ayuda a conocer la experiencia de pago de empresas y personas físicas, lo que a su vez contribuye a formar la cultura del crédito entre la población, al tiempo de promover un sano consumo interno.

\section{E. Control interno}

De acuerdo con el artículo 36 bis de la Ley Para Regular las Sociedades de Información Crediticia, le corresponderá al director general de la sociedad asegurarse de la implementación de procedimientos y medidas de control interno que garantice que el envío de información a otras sociedades se efectúe de manera oportuna, completa y sin distorsiones respecto de la que originalmente fue recibida de los usuarios.

\section{Fondos de inversión}

\section{A. Concepto y objeto}

El artículo 5o. de la Ley de Fondos de Inversión establece que los fondos de inversión son sociedades anónimas de capital variable que tendrán por objeto exclusivamente la adquisición y venta habitual y profesional de activos objeto de inversión con recursos provenientes de la colocación de las acciones representativas de su capital social ofreciéndolas a persona indeterminada, a través de servicios de intermediación financiera.

\section{B. Características}

Las sociedades de inversión representan una de las opciones más accesibles en materia de inversión para el pequeño y media- 
no inversionista, teniendo acceso a una gran variedad de instrumentos en el mercado de valores.

El ahorrador, al invertir sus recursos en una sociedad de inversión, adquiere acciones de esta empresa, y sus recursos se destinan a la adquisición de activos objeto de inversión seleccionados de acuerdo con los criterios de inversión y diversificación de riesgos, que establezca la sociedad.

La inversión en el mercado de valores no es de fácil acceso para el público inversionista, partiendo de los montos mínimos y el conocimiento necesario para hacer un portafolio especializado que atienda las necesidades de inversión.

De acuerdo con la nueva Ley de Sociedades de Inversión, el objeto de estas sociedades es la adquisición y venta de activos objeto de inversión con recursos provenientes de la colocación de las acciones representativas de su capital social entre el público inversionista, así como la contratación de los servicios y la realización de las demás actividades previstas en este ordenamiento, objetivos que se realizan a través de cuatro tipos de sociedades de inversión:

1) De renta variable. Estas sociedades invierten en una mezcla de activos objetos de inversión compuesta por valores de mercado de dinero, instrumentos de deuda, y del mercado de capitales, acciones y similares, de modo que sus ganancias son tanto por los intereses que generan los instrumentos de deuda como por los dividendos o incrementos de valor de las acciones. Dependiendo de la estrategia de la sociedad de inversión será el enfoque de plazo y certidumbre, pero podríamos decir que van desde un mediano plazo hasta un largo plazo, debido a la incorporación en su cartera de papeles que maduran o consolidan su rendimiento en periodos más largos que los de corto plazo, entre tres meses y un año, de mercado de dinero.

Es muy importante leer el prospecto para conocer la estrategia de inversión y los riesgos que puede tener cada sociedad de inversión de este tipo en particular. 
2) En instrumentos de deuda. Invierten en activos objeto de inversión, que representan deuda de los emisores, gobierno federal, banco o empresas privadas, de modo que en su mayoría, las ganancias que obtienen son a través de intereses, y en forma secundaria por la compraventa de los títulos. Este tipo de sociedades de inversión generalmente obtienen rendimientos más pequeños que la anterior, pero de una forma más constante; también puede decirse que son de menor plazo y están expuestas a una menor volatilidad. Esto depende de la estrategia de inversión.

La calificación de la sociedad de inversión, además del prospecto de información al público inversionista, es un buen elemento para seleccionar una sociedad de inversión con una correcta administración y calidad de papel en su cartera.

3) De capitales. Las sociedades de inversión de capitales operarán preponderantemente con activos objeto de inversión cuya naturaleza corresponda a acciones o partes sociales, obligaciones y bonos a cargo de empresas que promueva la propia sociedad de inversión y que requieran recursos a mediano y largo plazo. Estas compañías reciben el nombre de "empresas promovidas". Como su inversión es principalmente en el capital de las empresas, acciones, partes sociales u obligaciones, las ganancias de la sociedad de inversión, están relacionadas directamente con el desempeño de las empresas promovidas.

Es muy importante que el inversionista tenga en cuenta que la inversión en la mayoría de estas sociedades de inversión es de largo plazo, de un año o más.

En este tipo de sociedades de inversión es indispensable que el usuario conozca muy bien el prospecto de información al público y se mantenga al tanto de los reportes y asambleas de la sociedad de inversión, a través de la operadora, distribuidora o administradora, para conocer la situación que guarda su inversión. Se considera que este tipo de sociedad de inversión tiene más riesgos que los otros dos, pero también tiene posibilidad de mayores ganancias en el largo plazo, tres años o más. 
4) De objeto limitado. Estas sociedades van a operar con valores y documentos emitidos por empresas que requieren recursos a largo plazo y cuyas actividades están relacionadas, preferentemente, con los objetivos de planeación nacional del desarrollo.

Generalmente, estas sociedades nacen de la unión de grupos de personas con un objeto o fin común, que se unen para crear medios de financiamiento e inversión que beneficien su actividad productiva, mediante el otorgamiento de préstamos o créditos a cargo de los socios o la emisión de valores representativos de una deuda.

Las sociedades de inversión de objeto limitado operarán exclusivamente con los activos objeto de inversión que definan en sus estatutos y prospectos de información al público inversionista.

\section{Operaciones}

Los fondos de inversión sólo podrán realizar las operaciones siguientes:

1) Adquirir o enajenar activos objeto de inversión.

2) Celebrar operaciones de reporto y préstamo sobre valores, así como con instrumentos financieros derivados.

3) Comprar o vender acciones representativas del capital social de otros fondos de inversión.

4) Obtener préstamos y créditos.

5) Deberán obtener una calificación otorgada por alguna institución calificadora de valores, que refleje los riesgos de los activos integrantes de su patrimonio y de las operaciones que realicen, así como la calidad de su administración, cuando así lo determine la GNBV.

6) Deberán llevar el sistema de contabilidad que previene el Código de Comercio y los registros o auxiliares que ordene la Comisión. 
Los activos objeto de inversión son:

- Los valores, títulos y documentos a los que les resulte aplicable el régimen de la Ley del Mercado de Valores inscritos en el Registro Nacional o listados en el sistema internacional de cotizaciones.

- Los demás valores, recursos en efectivo, bienes, derechos y créditos, documentados en contratos e instrumentos, incluyendo aquellos referidos a operaciones financieras conocidas como "derivadas".

- Las demás cosas objeto de comercio que de conformidad con el régimen de inversión y en las disposiciones de carácter general que al efecto expida la Comisión para cada tipo de sociedad de inversión sean susceptibles de formar parte integrante del patrimonio de las sociedades de inversión.

\section{Organización}

Los fondos de inversión no contarán con asamblea de accionistas ni consejo de administración ni comisario tal como lo establece la Ley de Fondos de Inversión. Las funciones que comúnmente se asignan a la asamblea de accionistas estarán asignadas al socio fundador y en algunos casos a los demás socios. Igualmente, las actividades del consejo de administración quedarán encomendadas a la sociedad operadora de fondos de inversión. Por lo que corresponde a la vigilancia de los fondos de inversión, ésta se asigna al contralor normativo de la sociedad operadora de fondos de inversión contratada por el propio fondo.

Las sociedades operadoras de fondos de inversión que proporcionen servicios de administración a los fondos de inversión, a través de su propio consejo de administración, podrán realizar las funciones siguientes:

1) Aprobar la contratación de las personas que presten servicios al fondo de inversión; las normas para prevenir y evi- 
tar conflictos de intereses, y las operaciones con personas que mantengan nexos patrimoniales o de responsabilidad con el socio fundador o sus accionistas, o bien con los de la sociedad controladora del grupo financiero y entidades financieras integrantes del grupo al que, en su caso, pertenezca la propia sociedad operadora, así como con los accionistas del grupo empresarial o consorcio al que pertenezca dicha sociedad operadora.

2) Establecer las políticas de inversión y operación de los fondos de inversión, así como revisarlas cada vez que se reúna, tomando en cuenta si las inversiones resultan razonables para el fondo de inversión, la inexistencia de conflictos de interés, así como el apego al objetivo y horizonte de inversión.

3) Dictar las medidas que se requieran para que se observe debidamente lo señalado en el prospecto de información al público inversionista.

4) Analizar y evaluar el resultado de la gestión del fondo de inversión.

5) Abstenerse de pagar servicios no devengados o no contemplados en el prospecto de información al público inversionista del fondo de inversión.

6) Llevar un libro por separado de cada fondo de inversión que administre, en el cual se deberán asentar todos los actos corporativos del fondo de que se trate, relativos a cualquier modificación al acta constitutiva, incluyendo aumentos de capital, acuerdos de disolución, fusión, escisión, así como otros que tome el socio fundador, los cuales deberán informarse a la Comisión para su publicación a través del Registro Nacional; en caso de que se acuerde un aumento de capital del fondo de inversión que administre, el secretario del consejo podrá autenticar el acto registral correspondiente para su presentación ante la Comisión.

7) Llevar un registro del total de las acciones en circulación de los fondos de inversión que administre, con la información 
que le proporcionen las sociedades distribuidoras de acciones de fondos de inversión o entidades que prestan tal servicio, con la indicación del número, serie, clase y demás particularidades.

Los miembros del consejo de administración de las sociedades operadoras de fondos de inversión que administren a los fondos de inversión desempeñarán su función procurando la creación de valor en beneficio del fondo de inversión de que se trate, sin favorecer a un determinado accionista o grupo de accionistas.

Los fondos de inversión, a través del consejo de administración de la sociedad operadora de fondos de inversión, establecerán límites máximos de tenencia por accionista y determinarán políticas para que las personas que se ajusten a las mismas adquieran temporalmente porcentajes superiores a tales límites, debiendo esto contenerse en sus prospectos de información al público inversionista.

Las sociedades operadoras o las personas que presten servicios de distribución de acciones de fondos de inversión deberán implementar por cuenta de éstas, mecanismos que permitan a sus accionistas, contar con información oportuna relativa al porcentaje de su tenencia accionaria.

\section{Sociedades operadoras de fondos de inversión}

- Deberán inscribirse en el Registro Nacional, teniendo los mismos efectos que la inscripción en el Registro Público de Comercio.

- Los fondos de inversión no contarán con asamblea de accionistas, ni consejo de administración ni comisario. Las funciones de esas figuras estarán asignadas al socio fundador o a los demás socios.

- Las actividades del consejo de administración quedarán encomendadas a la sociedad operadora de fondos de inversión. 
- La vigilancia de los fondos de inversión corresponde a un contralor normativo de la sociedad operadora de fondos de inversión contratada por el propio fondo.

Las sociedades operadoras de fondos de inversión proporcionan servicios de administración a los fondos de inversión, a través de su propio consejo de administración, y tienen las funciones siguientes:

\section{- Aprobar:}

a) La contratación de las personas que presten servicios al fondo de inversión.

b) Normas para prevenir y evitar conflictos de intereses.

- Establecer las políticas de inversión y operación de los fondos de inversión.

- Analizar y evaluar el resultado de la gestión del fondo de inversión.

— Establecer límites máximos de tenencia por accionista. 


\section{I. Овјето}

Este sector se encarga del ahorro y crédito popular, con la finalidad de apoyar a las micro, pequeñas y medianas empresas; es decir, su finalidad es mejorar la situación económica de las comunidades en las que existen. Estas entidades se conocen de la siguiente manera:

- Sociedad cooperativa de ahorro y préstamo.

- Caja popular.

- Caja de ahorro.

- Caja rural.

- Entidad de ahorro y crédito popular.

Es importante mencionar que estas entidades son autorizadas y supervisadas por la GNBV, y cuentan con sus propios fondos de protección.

Las federaciones integran entidades, y las confederaciones integran federaciones, con la finalidad de administrar fondos de protección; además, cuentan con las siguientes funciones:

- Fungir como representantes legales de los afiliados.

- Brindar asesoría técnica, legal, financiera y de capacitación a sus afiliados.

- Contratar créditos para los afiliados que lo requieran.

- Expedir y operar tarjetas de débito y tarjetas recargables.

- Negociar títulos de crédito. 
- Realizar inversiones en valores.

- Recibir pago de servicios por cuenta de terceros.

- Realizar la compraventa de divisas en ventanilla por cuenta de terceros o propia.

- Celebrar como arrendatarias, contratos de arrendamiento financiero.

- Recibir donativos.

\section{FONDO DE PROTECAIÓN}

Se le conoce así al sistema de protección que se constituye de conformidad con lo señalado en el capítulo VI de la Ley de Ahorro y Crédito Popular, con el propósito de procurar cubrir a los ahorradores sus depósitos de dinero en los términos y con las limitaciones señalados.

La constitución del fideicomiso por el gobierno federal deberá efectuarse en una institución de banca de desarrollo, que actuará como institución fiduciaria. El fideicomiso no tendrá el carácter de entidad de la administración pública federal ni de fideicomiso público, y, por lo tanto, no estará sujeto a las disposiciones aplicables a dichas entidades. El fondo de protección para el cumplimiento de sus fines se apoyará en un comité técnico, así como en un comité de protección al ahorro. Los comités se organizarán y contarán con las funciones que la Ley de Ahorro y Crédito Popular establezca.

El patrimonio del fondo se integrará de la siguiente manera:

1) Las aportaciones que el gobierno federal efectúe.

2) Las cuotas mensuales ordinarias que deberán cubrir las sociedades financieras populares, las cuales se determinarán tomando en consideración el riesgo a que se encuentren expuestas, con base en el nivel de capitalización y de los pasivos totales de cada sociedad financiera popular. 
Dichas cuotas ordinarias serán de entre uno y tres al millar anual sobre el monto de pasivos de la sociedad financiera popular que sea objeto de protección.

El rango dentro del cual se ubicarán las aportaciones y la forma para calcular y pagar mensualmente la aportación respectiva serán determinados por el comité técnico con base en lo que para tales efectos establezca la Comisión mediante disposiciones de carácter general.

3) Las cuotas extraordinarias a cargo de las sociedades financieras populares que determine el comité técnico, previa autorización de la Comisión, y

4) Los demás bienes, derechos y obligaciones que el propio fondo adquiera por cualquier título legal.

Los recursos a que se refieren las fracciones I, II y III, que integren el Fondo de Protección, deberán invertirse en valores gubernamentales de amplia liquidez o en títulos representativos del capital social de sociedades de inversión en instrumentos de deuda, de conformidad con lo que determine la Comisión a través de disposiciones de carácter general.

Los comités de supervisión deberán entregar al comité de protección al ahorro, la información que éste requiera para determinar las cuotas, de conformidad con las facultades descritas en la Ley de Ahorro y Crédito Popular.

El comité de protección al ahorro podrá acordar la suspensión temporal de las cuotas al Fondo de Protección, cuando los recursos que integren el mismo representen cuando menos el cinco por ciento del total de depósitos de ahorros de todas las sociedades financieras populares que estén protegidos por dicho Fondo de Protección.

El Fondo de Protección tendrá como fin primordial, procurar cubrir los depósitos de dinero de cada ahorrador, hasta por una cantidad equivalente a veinticinco mil unidades de inversión, por persona física o moral, cualquiera que sea el número y clase de operaciones a su favor y a cargo de una misma sociedad 
financiera popular, en caso de que se declare su disolución y liquidación, o se decrete su concurso mercantil.

\section{FEDERACIONES}

Las federaciones son organismos de integración, de interés público, con personalidad jurídica y patrimonio propios.

Su propósito fundamental es fortalecer los vínculos naturales y culturales de sus asociadas, así como implementar servicios especializados de calidad que coadyuven al desarrollo de sus funciones, incidiendo también en la competitividad, seguridad y fortalecimiento de la imagen pública de las cooperativas financieras.

\section{SOGIEDADES FINANGIERAS POPUlaRES (SOFIPOS)}

Son instituciones de microfinanzas constituidas como sociedades anónimas de capital variable, que operan mediante la autorización que les otorga la Comisión Nacional Bancaria y de Valores.

En su carácter de sociedades anónimas, deben cumplir también con la Ley General de Sociedades Mercantiles, ya que son empresas privadas y su capital se integra con las aportaciones que hacen sus accionistas.

Las sociedades financieras populares tienen su domicilio en territorio nacional, con una duración indefinida, y están facultadas para prestar servicios tanto a sus socios como a sus clientes, en los términos de la LACP.

Las sociedades financieras comunitarias cuyo monto total de activos no rebase el límite equivalente en moneda nacional a 2,500,000 de UDIS contarán con un nivel de operaciones básico, y no requerirán de la autorización de la CNBV para desarrollar las operaciones propias de su objeto. Estas sociedades sólo podrán operar con socios. 


\section{Objetivo}

Las sociedades financieras populares tienen como propósito fomentar el ahorro popular y expandir el acceso al financiamiento a aquellas personas que por su situación se han visto excluidas de los sistemas tradicionales de crédito, y en general, propiciar la solidaridad, la superación económica y social, y el bienestar de sus miembros y de las comunidades en que operan, sobre bases formativas y del esfuerzo individual y colectivo.

\section{SOGIEDADES FINANGIERAS COMUNITARIAS (SFG)}

Las sociedades financieras comunitarias y los organismos de integración financiera rural tienen como propósito promover la educación financiera rural, la cual tendrá por objeto propiciar el ahorro y el apoyo crediticio para el desarrollo de las actividades productivas del sector rural, para lo cual podrán recibir donativos y apoyos de los gobiernos federal, estatales y municipales.

La legislación vigente en comento sentó las bases para la constitución de las sociedades financieras populares y sociedades financieras comunitarias, en su carácter de instituciones de microfinanzas, cuyo modelo de negocio es proporcionar servicios financieros a los sectores y comunidades que carecen de ellos, diseñando servicios financieros ajustados a las características del mercado y al riesgo que presentan, para responder a la demanda de las poblaciones de escasos recursos excluidas del sector financiero.

Las sociedades financieras populares y sociedades financieras comunitarias proporcionan a sus clientes y socios:

- Acceso a microcréditos ajustados a las características de los clientes, al mercado, a la región geográfica y al riesgo que presentan. 
- Acceso a servicios financieros, a personas de bajos ingresos, ofreciéndoles la oportunidad de mantener de forma segura sus ahorros.

- Fortalecer el sistema de protección de los ahorros del sector de microfinanzas y el esquema de supervisión auxiliar.

- Acceso a operaciones como el arrendamiento y el factoraje financiero.

- Adherirse a los beneficios de una póliza de seguro de vida, a bajo costo.

- Capacitación en el análisis de proyectos de inversión.

- Asistencia técnica para elaborar planes de negocios y proyectos de comercialización.

- Desarrollo comunitario sobre bases formativas y del esfuerzo individual y colectivo.

\section{SOCIEDADES GOOPERATIVAS DE AHORRO Y PRÉSTAMO (SOCAPS)}

Aquellas sociedades constituidas y organizadas conforme a la Ley General de Sociedades Cooperativas que, independientemente del nombre comercial, razón o denominación social que adopten, tengan por objeto realizar operaciones de ahorro y préstamo con sus socios, y quienes forman parte del sistema financiero mexicano con el carácter de integrantes del sector social sin ánimo especulativo y reconociendo que no son intermediarios financieros con fines de lucro.

\section{Objetivo del sector}

Consolidar un sector de sociedades cooperativas de ahorro y préstamo, que cuente en su totalidad con un registro y para el caso de aquellas con activos superiores a 2.5 millones de UDIS con la autorización de la GNBV, las cuales como parte del sector social del sistema financiero mexicano contribuyan a la inclusión financiera de la población de las comunidades en las que operan a fin 
de hacerles llegar productos y servicios financieros de calidad que ayuden a sus socios a mejorar su situación económica, y coadyuvar con el gobierno federal para la difusión, entrega y administración de los programas de apoyos que éste promueva, a fin de que los mismos lleguen de forma integral a sus beneficiarios incrementando el efecto positivo con el cual sean implementados.

Integración: Las Socaps deben estar inscritas en el Registro de Socaps que lleva el Fondo de Protección a través de su Comité de Supervisión Auxiliar. Conforme a la LRASCAP, el Fondo de Protección debe poner a disposición del público en general, a través de su página electrónica, la información correspondiente al Registro.

El sector de Socaps se compone de:

- Socaps con nivel de operación básico. Son aquellas que cuentan con activos iguales o inferiores a 2.5 millones de UDIS. Deben entregar al Comité de Supervisión Auxiliar del Fondo de Protección información financiera de manera semestral o trimestral dependiendo del número de socios. Estas sociedades no requieren de la autorización ni son supervisadas por la CNBV, además de que no participan ni cuentan con la protección del seguro de depósitos. No obstante lo anterior, estas sociedades pueden solicitar su autorización como Socap con nivel de operación I y de esta forma participar en el Fondo de Protección.

- Socap con niveles de operación I a IV. Son aquellas que cuentan con activos superiores a 2.5 millones de UDIS y que han obtenido la autorización de la Comisión Nacional Bancaria y de Valores, CNBV, para realizar o continuar realizando operaciones de ahorro y préstamo, y que como sociedades autorizadas se encuentran sujetas a la supervisión de esta Comisión, así como a la del Comité de Supervisión Auxiliar del Fondo de Protección, teniendo la obligación de remitir de manera mensual, trimestral y anual, información financiera. Lo anterior, con la 
finalidad de preservar la operación de las cooperativas, su sano y equilibrado desarrollo y proteger los ahorros de los socios. Estas sociedades participan y cuentan con la protección del seguro de depósitos con una cobertura de hasta 25,000 UDIS por socio. Se pueden consultar en el Padrón de Entidades Supervisadas, sector de entidades de ahorro y crédito popular, subsector de sociedades cooperativas de ahorro y préstamo.

- Fondo de protección, el cual para el cumplimiento de sus fines se apoyará en un comité técnico, así como en un Comité de Supervisión Auxiliar y en un Comité de Protección al Ahorro Cooperativo.

- Socap en "Prórroga Condicionada". Son aquellas con activos superiores a 2.5 millones de UDIS que se encuentran en proceso de regularización y operan al amparo del régimen transitorio de la LRASCAP, mejor conocido como "Prórroga condicionada". Estas sociedades no cuentan con autorización ni son supervisadas por la GNBV, además de que no participan ni cuentan con la protección del seguro de depósitos. Estas sociedades deben someterse a una evaluación por parte del Comité de Supervisión Auxiliar del Fondo de Protección, que es responsable de clasificarlas en función al cumplimiento de los requisitos mínimos.

De acuerdo con lo que se establece en el artículo 62 de la LRASCAP, la supervisión de las Socaps con niveles de operación I a IV y del Fondo de Protección está a cargo de la CNBV. Asimismo, el Comité de Supervisión Auxiliar del Fondo de Protección está facultado para realizar supervisión auxiliar a las Socaps.

El Banco de Ahorro Nacional y Servicios Financieros, S. N. C. (Bansefi) se reconoce como una institución vinculada directamente al sector de Socaps, en razón de que cuenta entre sus tareas fundamentales: coadyuvar en el proceso de inclusión financiera, dispersar programas de apoyo gubernamentales, y servir 
como banco de desarrollo de segundo piso de las organizaciones del ahorro y crédito popular y cooperativo contempladas en las diversas leyes; asimismo, Bansefi se encarga de apoyar los trabajos de consolidación necesarios a fin de que se logren los apoyos que establece la Ley del Fideicomiso de Pago (Fipago).

Por último, la Comisión Nacional para la Protección y Defensa de los Usuarios de Servicios Financieros, Condusef, también participa en tareas de inclusión financiera, de difusión relacionada con el sector y ejerce sobre las Socaps la supervisión que les corresponde a sus facultades. 


\section{PARTE INTERNACIONAL}




\section{Capítulo nOveno}

\section{TRATADOS INTERNACIONALES EN MATERIA DE GOMERGIO Y SERVIGIOS FINANGIEROS}

\section{LOS TRATADOS INTERNACIONALES COMERCIALES DE MÉXICO}

Por tratados celebrados por México debe entenderse cualquier "acuerdo internacional celebrado por escrito entre Estados y regido por el derecho internacional, ya conste en un instrumento único o en dos o más instrumentos conexos y cualquiera que sea su denominación particular", artículo 2o., inciso a, de la Convención de Viena sobre el Derecho de los Tratados de 1969, así como aquellos celebrados entre México y organizaciones internacionales.

México cuenta con 1,270 tratados - 653 bilaterales, 617 multilaterales y 12 comerciales - que le dan preferencia arancelaria a más de 46 países, entre los que se destacan los siguientes: ${ }^{100}$

\section{TABLA 2}

\begin{tabular}{|l|l|l|l|l|}
\hline País & Firmado & Aprobado & Publicado & En vigor \\
\hline $\begin{array}{l}\text { Estados } \\
\text { Unidos } \\
\text { C Canada }\end{array}$ & $\begin{array}{l}17 \text { de } \\
\text { diciembre } \\
\text { de } 1992\end{array}$ & $\begin{array}{l}22 \text { de } \\
\text { noviembre } \\
\text { de } 1993\end{array}$ & $\begin{array}{l}\text { 20 de } \\
\text { diciembre } \\
\text { de } 1993\end{array}$ & $\begin{array}{l}\text { 1 de enero } \\
\text { de } 1994\end{array}$ \\
\hline Costa Rica & $\begin{array}{l}5 \text { de abril } \\
\text { de } 1994\end{array}$ & $\begin{array}{l}21 \text { de junio } \\
\text { de } 1994\end{array}$ & $\begin{array}{l}10 \text { de enero } \\
\text { de } 1995\end{array}$ & $\begin{array}{l}1 \text { de enero } \\
\text { de } 1995\end{array}$ \\
\hline
\end{tabular}

100 Quintana Adriano, Elvia Arcelia, El comercio exterior de México. Marco jurídico, estructura y política, 3a. ed. (corregida y aumentada), México, Porrúa, 2010, p. 495. 


\begin{tabular}{|c|c|c|c|c|}
\hline País & Firmado & Aprobado & Publicado & En vigor \\
\hline Colombia & $\begin{array}{l}13 \text { de junio } \\
\text { de } 1994\end{array}$ & $\begin{array}{l}13 \text { de junio } \\
\text { de } 1994\end{array}$ & $\begin{array}{l}31 \text { de } \\
\text { diciembre } \\
\text { de } 1994\end{array}$ & $\begin{array}{l}1 \text { de enero } \\
\text { de } 1995\end{array}$ \\
\hline Bolivia & $\begin{array}{l}10 \text { de sep- } \\
\text { tiembre } \\
\text { de } 1994\end{array}$ & $\begin{array}{l}28 \text { de diciem- } \\
\text { bre de } 1994\end{array}$ & $\begin{array}{l}11 \text { de enero } \\
\text { de } 1995\end{array}$ & $\begin{array}{l}1 \text { de enero } \\
\text { de } 1995\end{array}$ \\
\hline Nicaragua & $\begin{array}{l}18 \text { de diciem- } \\
\text { bre de } 1997\end{array}$ & $\begin{array}{l}30 \text { de abril } \\
\text { de } 1998\end{array}$ & $\begin{array}{l}29 \text { de junio } \\
\text { de } 1998\end{array}$ & $\begin{array}{l}1 \text { de julio } \\
\text { de } 1998\end{array}$ \\
\hline Chile & $\begin{array}{l}17 \text { de abril } \\
\text { de } 1998\end{array}$ & $\begin{array}{l}23 \text { de } \\
\text { noviembre } \\
\text { de } 1998\end{array}$ & $\begin{array}{l}28 \text { de julio } \\
\text { de } 1999\end{array}$ & $\begin{array}{l}1 \text { de agosto } \\
\text { de } 1999\end{array}$ \\
\hline Uruguay & $\begin{array}{l}15 \text { de } \\
\text { noviembre } \\
\text { de } 2003\end{array}$ & $\begin{array}{l}28 \text { de abril } \\
\text { de } 2004\end{array}$ & $\begin{array}{l}25 \text { de junio } \\
\text { de } 2004\end{array}$ & $\begin{array}{l}15 \text { de julio } \\
\text { de } 2004\end{array}$ \\
\hline $\begin{array}{l}\text { El Salvador, } \\
\text { Guatemalay } \\
\text { Honduras }\end{array}$ & $\begin{array}{l}28 \text { de junio } \\
\text { de } 2000\end{array}$ & $\begin{array}{l}19 \text { de enero } \\
\text { de } 2001\end{array}$ & $\begin{array}{l}14 \text { de marzo } \\
\text { de } 2001\end{array}$ & $\begin{array}{l}15 \text { de marzo } \\
\text { de } 2001\end{array}$ \\
\hline Unión Europea & $\begin{array}{l}23 \text { de marzo } \\
\text { de } 2000\end{array}$ & $\begin{array}{l}20 \text { de marzo } \\
\text { de } 2000 \\
\text { (Acuerdo } \\
\text { Global) }\end{array}$ & $\begin{array}{l}26 \text { de junio } \\
\text { de } 2000\end{array}$ & $\begin{array}{l}1 \text { de julio de } \\
2000 \text { (Bienes) } \\
1 \text { de marzo } \\
\text { de } 2001 \\
\text { (Servicios e } \\
\text { inversión) }\end{array}$ \\
\hline Israel & $\begin{array}{l}10 \text { de abril de } \\
2000\end{array}$ & $\begin{array}{l}10 \text { de abril de } \\
2000\end{array}$ & $\begin{array}{l}10 \text { de abril de } \\
2000\end{array}$ & $\begin{array}{l}10 \text { de abril de } \\
2000\end{array}$ \\
\hline $\begin{array}{l}\text { Asociación } \\
\text { Europea de } \\
\text { Libre Comercio } \\
\text { (AELC) }\end{array}$ & $\begin{array}{l}27 \text { de } \\
\text { noviembre de } \\
2000\end{array}$ & $\begin{array}{l}30 \text { de abril de } \\
2001\end{array}$ & $\begin{array}{l}29 \text { de junio } \\
\text { de } 2001\end{array}$ & $\begin{array}{l}1 \text { de julio de } \\
2001\end{array}$ \\
\hline Fapón & $\begin{array}{l}17 \text { de sep- } \\
\text { tiembre de } \\
2004\end{array}$ & $\begin{array}{l}18 \text { de } \\
\text { noviembre de } \\
2004\end{array}$ & $\begin{array}{l}31 \text { de marzo } \\
\text { de } 2005\end{array}$ & $\begin{array}{l}1 \text { de abril de } \\
2005\end{array}$ \\
\hline
\end{tabular}




\section{LOS TRATADOS INTERNACIONALES FINANCIEROS DE MÉXICO}

En cuanto a los tratados que tienen que ver con la materia de finanzas, se mencionan a continuación los siguientes: ${ }^{101}$

- Tratado multilateral: Convenio sobre el Fondo Monetario Internacional, vigente a partir del 31 de diciembre de 1945.

- Tratado multilateral: Convenio sobre el Banco Internacional de Reconstrucción y Fomento, vigente a partir del 14 de marzo de 1946.

- Tratado multilateral: Convenio Constitutivo del Banco Interamericano de Desarrollo, vigente a partir del 30 de diciembre de 1959.

- Tratado multilateral: Convenio Constitutivo de la Corporación Financiera Internacional, vigente a partir del 20 de julio de 1956.

- Tratado multilateral: Convenio Constitutivo de la Corporación Interamericana de Inversiones, vigente a partir del 10 de septiembre de 1986.

- Tratado multilateral: Convenio Constitutivo del Organismo Multilateral de Garantía de Inversiones, vigente a partir del 17 de junio del 2008.

- Tratado multilateral: Protocolo relativo a las Inmunidades del Banco de Pagos Internacionales, vigente a partir del 10 de agosto de 2000.

- Tratado multilateral: Convenio Constitutivo del Banco de Desarrollo del Caribe, vigente a partir del 7 de mayo de 1982.

101 Sistema de Información de Tratados Comerciales Internacionales, Secretaría de Economía, disponible en: http://wrere.economia-snci.gob.mx/sicait/5.0/. 
- Tratado multilateral: Convenio Constitutivo del Banco Interamericano de Integración Económica, vigente a partir del 28 de octubre de 1992.

- Tratado multilateral: Convenio Constitutivo del Banco Europeo de Reconstrucción y Desarrollo, vigente a partir del 28 de marzo de 1991.

- Tratado multilateral: Convenio Constitutivo del Banco Centroamericano de Integración Económica, vigente a partir del 6 de febrero de 2003.

- Tratado multilateral: Convenio Constitutivo del Fondo Multilateral de Inversiones II, vigente a partir del 13 de marzo de 2007.

Las instituciones internacionales juegan un rol muy importante a nivel mundial con la creación de programas y medidas comerciales y financieras que han logrado que exista un mejor funcionamiento financiero y económico internacional. El apoyo y la cooperación entre ellas permiten que trabajen juntas hacia el logro de los mismos objetivos, teniendo igualdad de jerarquías en cada uno de los ámbitos que les compete, fomentando con esto una adecuada gobernanza a nivel mundial.

\section{Tratado de Libre Comercio de América del Norte (TLCAN)}

Este tratado de libre comercio considera en su capítulo XIV lo relativo a los servicios financieros, y en su contenido remarca lo que debe entenderse por servicio financiero "que significa un servicio de naturaleza financiera, inclusive seguros, y cualquier servicio conexo o auxiliar a un servicio de naturaleza financiera".

Autoridades responsables de los servicios financieros

La autoridad de cada una de las partes responsable de los servicios financieros será: 
a) Para México, la Secretaría de Hacienda y Crédito Público.

b) Para Canadá, el Department of Finance of Canada.

c) Para Estados Unidos, el Department of the Treasury, tratándose de banca y otros servicios financieros, y el Department of Commerce tratándose de servicios de seguros.

Los temas relativos a este capítulo se refieren a los siguientes aspectos: ámbito de aplicación; organismos reguladores autónomos; derecho de establecimiento de instituciones financieras; comercio transfronterizo; trato nacional; trato de nación más favorecida; nuevos servicios financiero y procesamiento de datos; alta dirección y consejos de administración; reservas y compromisos; excepciones; transparencia; comité de servicios financieros; consultas; solución de controversias.

A continuación se mencionan los principales acuerdos que se han celebrado entre estas instituciones.

\section{Acuerdo de cooperación del FMI celebrado con la OMC en 1996}

- Primero, establece la base para el cumplimiento del mandato ministerial de la OMC de alcanzar una mayor coherencia en la formulación de la política económica a escala mundial, cooperando con el FMI, así como con el Banco Mundial.

- Segundo, al reconocer la convergencia de las tareas y responsabilidades del FMI y la OMC, el acuerdo crea canales de comunicación para velar por que los derechos y obligaciones de los miembros sean parte integrante de la filosofía de cada organización.

- Tercero, en pro del fortalecimiento de la cooperación, el Acuerdo concede recíprocamente al FMI y la OMC la condición de observador en algunos órganos rectores de la otra organización. 


\section{Acuerdos del Fondo Monetario Internacional y el Grupo del Banco Mundial}

Coordinación de alto nivel: durante las Reuniones Anuales de las Juntas de Gobernadores del FMI y el Banco Mundial, los gobernadores se consultan y presentan la opinión de sus países acerca de cuestiones actuales de las finanzas y la economía internacionales.

Deliberaciones de los directivos: el director gerente del FMI y el presidente del Banco Mundial se reúnen con regularidad para deliberar acerca de los temas más importantes.

Colaboración del personal: el personal técnico del FMI y del Banco colabora estrechamente en la asistencia a los países y en cuestiones de política económica relevantes para ambas instituciones.

Reducción de la carga de la deuda: el FMI y el Banco Mundial también están colaborando para reducir la carga que impone la deuda externa a los países pobres más endeudados en el marco de la Iniciativa para la Reducción de la Deuda de los Países Pobres muy Endeudados (PPME), y la Iniciativa para el Alivio de la Deuda Multilateral (IADM).

Reducción de la pobreza: en 1999, el FMI y el Banco Mundial adoptaron el enfoque del Documento de Estrategia de Lucha contra la Pobreza (DELP): una estrategia encabezada por los países para establecer una vinculación entre las políticas nacionales, el apoyo de los donantes y los resultados que deben alcanzarse en materia de desarrollo a fin de reducir la pobreza en los países de bajo ingreso.

Seguimiento de los avances de los ODM: desde 2004, el FMI y el Banco Mundial han trabajado en forma conjunta en la elaboración del informe Global Monitoring Report (GMR). En este informe anual se evalúan los avances relativos a las políticas y medidas necesarias para alcanzar los Objetivos de Desarrollo del Milenio (ODM) de las Naciones Unidas. 
Evaluación de la estabilidad financiera: el FMI y el Banco Mundial también trabajan en forma mancomunada para que el sector financiero de los países miembros sea flexible y esté bien reglamentado. En 1999 se puso en marcha el Programa de Evaluación del Sector Financiero (PESF) con objeto de identificar los puntos fuertes y débiles del sistema financiero de un país y recomendar, en consecuencia, las medidas de política apropiadas.

El FMI se ocupa de cuestiones macroeconómicas, mientras que el Banco Mundial se concentra en el desarrollo económico a largo plazo y en la reducción de la pobreza.

En la dinámica comercial financiera existen acuerdos internacionales que con base en su objeto se vinculan con organismos internacionales; de ahí que la Organización Mundial del Comercio tenga dentro de sus finalidades, facilitar la cooperación de sus miembros en el desarrollo de las relaciones comerciales, donde se integran bajo una misma estructura tres grandes acuerdos: el de mercancías (GATT); el Acuerdo sobre el Comercio de Servicios (AGCS) y el Acuerdo sobre los Aspectos de los Derechos de Propiedad Intelectual (ADPIC).

Respecto del GATT, en el artículo XV se establece la estrecha relación entre éste y el FMI. Este artículo señala en qué áreas las partes contratantes establecerán relaciones con el FMI y otorga a las partes contratantes autoridad para:

\section{- Cooperar con el FMI.}

- Proveer información al FMI sobre restricciones cambiarias inconsistentes con el GATT.

- Especificación de los acuerdos cambiarios para partes contratantes no miembros del FMI.

- Requerir información similar a la solicitada por el FMI.

El área donde ha existido una verdadera actuación conjunta entre el GATT y el FMI ha sido las consultas sobre balanza de pagos. El acuerdo permite a las partes contratantes, proteger su situación financiera externa y evitar un deterioro de la balanza 
de pagos, a través de la imposición de restricciones cuantitativas por motivos de balanza de pagos. En los dos casos, se reserva al Fondo un papel fundamental en estas consultas.

El Acuerdo General sobre el Comercio de Servicios (AGCS) establece por primera vez normas multilaterales para regular el comercio de servicios y a su vez fomentar una mayor liberalización de este sector.

El AGCS abarca todos los servicios que son objeto de comercio internacional, y considera como servicios financieros "todo servicio de carácter financiero ofrecido por un proveedor de servicios financieros de un Miembro". Los servicios financieros comprenden todos los servicios de seguros y relacionados con seguros y todos los servicios bancarios y demás servicios financieros (excluidos los seguros).

Con la regulación del sector de los servicios a nivel mundial, expresamente en el AGCS, se pretende obtener un rápido crecimiento de la economía internacional, aportando dos tercios de la producción mundial. Genera en muchos países un alto número de empleos, toda vez que las ventajas potenciales que provoca la liberación de los servicios son tan amplias como en el sector de las mercancías.

Así, el acceso a los servicios mundiales contribuye, tanto a los exportadores como productores de los países en desarrollo, a aprovechar su capacidad productiva, independientemente de los bienes y servicios que estén ofreciendo en el mercado, sea en el ramo del turismo o la construcción. Por ello, la liberalización de los servicios se ha convertido en un elemento clave de un sinnúmero de estrategias de desarrollo.

El Acuerdo sobre los Aspectos de los Derechos de Propiedad Intelectual relacionados con el Comercio (ADPIG) que protege los derechos de autor, las denominaciones de origen, las marcas y los secretos comerciales, entre otros. Los derechos sustantivos son una característica nueva del sistema comercial multilateral, que conllevan un derecho de propiedad o una oportunidad para un agente económico, que es garantizada legalmente. 


\section{ORGANISMOS FINANCIEROS INTERNACIONALES}

La existencia de organismos y acuerdos internacionales son precisiones jurídicas de las relaciones que se establecen a nivel mundial. Su objetivo es producir un efecto de carácter económico o regular las actividades en un ámbito económico, monetario o financiero que va más allá de lo estrictamente nacional.

Según el vínculo jurídico creado que afecte a dos o más países, se tratará de entidades o acuerdos bilaterales o multilaterales. Estos últimos, a su vez, dan lugar a instituciones supranacionales o intergubemamentales, según tengan una personalidad jurídica separada o constituyan un marco al que las partes intervinientes acuerdan tener sus respectivas políticas nacionales en el área objeto del acuerdo intergubernamental. El conjunto de estas instituciones forman una red que condiciona de modo fundamental el desarrollo integral de los países y de la economía internacional. Los organismos financieros internacionales son parte esencial de esa red. Su actividad está orientada a la financiación del desarrollo global, la estabilidad financiera, la cooperación financiera o el desarrollo regional. ${ }^{102}$

Las organizaciones internacionales gozan de personalidad jurídica, esto es, de la capacidad de ejercer ciertos derechos y asumir determinadas obligaciones en el marco de sistemas jurídicos concretos: nacional e internacional. Ahora bien, a diferencia de los Estados, sujetos soberanos y jurídicamente iguales que poseen una personalidad jurídica plena y general, la personalidad de las organizaciones internacionales se ve afectada por el principio de especialidad que "inspira" y "determina" todo su régimen jurídico: en otras palabras, la existencia de estas organizaciones va a estar "limitada" a los objetivos y funciones que les fueron

102 Calvo Hornero, Antonio, "Organismos financieros internacionales: bancos regionales de desarrollo e instituciones financieras multilaterales", Revista de Economía Mundial, 2000. 
confiados, tal como aparecen enunciados y descritos, o que puedan deducirse, de los tratados constitutivos. ${ }^{103}$

Se conoce como organización internacional a toda asociación de Estados que adopte una estructura orgánica permanente. ${ }^{104}$ Estas asociaciones se ven identificadas por cuatro rasgos esenciales:

- Conformadas esencialmente por los Estados.

- Creadas por un tratado o acuerdo multilateral, o bien por una resolución de una organización internacional ya existente.

- Posesión de una estructura orgánica permanente.

- Una personalidad jurídica propia.

Los organismos financieros internacionales son instituciones de desarrollo cuya meta es reducir la pobreza promoviendo el crecimiento económico sostenible a través de asistencia técnica y apoyo financiero.

Los organismos financieros internacionales pueden tener carácter supranacional o intergubernamental y son diferentes de las denominadas organizaciones no gubernamentales, organizaciones no gubernamentales, que también disponen de una estructura institucional, pero en lo que no participan Estados o administraciones públicas, constituyendo asociaciones que pueden reunir a personas físicas o jurídicas de carácter público o privado, de un solo Estado o de diferentes Estados. Estas últimas son personas jurídicas que se constituyen y se mueven en el ámbito

103 Diez de Velasco, Manuel, Las organizaciones internacionales, Madrid, Tecnos, 1994, p. 54.

104 Barboza, Julio, Derecho internacional público, Buenos Aires, Zavalía, 1999, p. 533. Siguiendo el concepto de Rogelio Moreno Rodríguez, podemos definir a toda organización internacional como una asociación de Estados, regida por un acuerdo internacional, que establece una estructura permanente de órganos con atribuciones propias que expresan la voluntad de los Estados y dan cumplimiento a los fines para los cuales se asociaron. 
del derecho privado, en tanto que los organismos internacionales pertenecen a la esfera del derecho internacional público.

La estructura de funcionamiento de los organismos financieros internacionales está diversificada, dado el elevado número de Estados participantes, según su carácter supranacional ${ }^{105}$ con autonomía patrimonial y de decisión en el campo definido por su estatuto o su carácter intergubernamental. En ambos casos existe un órgano supremo, que es la asamblea o junta general, donde están presentes todos los Estados miembros participantes que adoptan las principales líneas de actuación de la organización. Para agilizar su funcionamiento se delegan algunas funciones en un órgano ejecutivo, compuesto por un número limitado de miembros.

La necesidad de establecer organismos internacionales de cooperación y de desarrollo surge especialmente al final de la Segunda Guerra Mundial. La Conferencia de San Francisco (1945) donde se aprobó formalmente la Carta de la Naciones Unidas, al final de la Conferencia, marca el inicio del auge de las organizaciones económicas internacionales, donde los derechos y deberes de los Estados tienen acogida.

El hecho más significativo de esta ordenación económica internacional surgió de la Conferencia de Bretton Woods en 1944. El mundo había atravesado la amarga experiencia de dos guerras mundiales y una profunda recesión derivada de la Gran Depresión de 1929. El nacionalismo económico y la falta de objetivos globales para hacer frente a los problemas acuciaron aún más los efectos de la recesión económica.

La ordenación económica surgida de la Segunda Guerra Mundial hizo posible que a partir de entonces los problemas globales pudieran ser abordados por diferentes organizaciones e instituciones internacionales, delimitándose los campos de intervención: 1) pagos internacionales; 2) comercio mundial; 3) productos básicos, y 4) financiación del desarrollo. ${ }^{106}$

105 Se aplica a la institución u organismo que no depende de una nación en concreto o que está por encima de una o más naciones.

106 Calvo Hornero, Antonio, op. cit. 


\section{Banco Mundial}

El Banco Mundial surge en 1944 con objeto de financiar la reconstrucción de países luego de conflictos bélicos.

Actualmente, el ahora conocido como el "Grupo del Banco Mundial" tiene como facultades no sólo la financiación para la reconstrucción de países después de conflictos bélicos, sino que además financia a economías en desarrollo en casos de desastres naturales, proyectos para el sector social, la lucha contra la pobreza, el alivio de la deuda y el buen gobierno.

El Grupo del Banco Mundial es una organización compleja que abarca cinco instituciones:

- Banco Internacional de Reconstrucción y Fomento (BIRF), creado en 1944, que otorga préstamos a gobiernos de países de ingreso mediano y de ingreso bajo con capacidad de pago.

- La Corporación Financiera Internacional (CFI), creada en 1956, que tiene como objetivo apoyar al sector privado de los países subdesarrollados a lograr un crecimiento sostenible, financiando inversiones, movilizando capitales en los mercados financieros internacionales y la prestación de servicios de asesoramiento a empresas y gobiernos.

- La Asociación Internacional de Fomento (AIF), creada en 1960, que concede préstamos sin interés, o créditos, así como donaciones a gobiernos de los países más pobres.

- En 1966 se crea el Centro Internacional de Arreglo de Diferencias Relativas a Inversiones (CIADI), que lleva a cabo tareas de conciliación o arbitraje entre los distintos Estados y los inversores extranjeros.

- El Organismo Multilateral de Garantía de Inversiones (OMGI), creado en 1988, que promueve la inversión extranjera directa en los países en desarrollo, apoya el crecimiento económico, reduce la pobreza y mejora la vida de las per- 
sonas, ofreciendo seguros contra riesgos políticos, garantías, a inversores.

Fines del Grupo del Banco Mundial. El Banco Mundial fue establecido mediante un convenio constitutivo, el cual establece como fines del banco los siguientes:

1) Contribuir a la obra de reconstrucción y fomento en los territorios de miembros.

2) Fomentar la inversión extranjera privada mediante garantías o participaciones en préstamos y otras inversiones que hicieren inversionistas privados.

3) Promover el crecimiento equilibrado y de largo alcance del comercio internacional, así como el mantenimiento del equilibrio de las balanzas de pagos.

4) Coordinar los préstamos que haga o garantice con los préstamos internacionales tramitados por otros conductos.

5) Dirigir sus operaciones con la debida atención a los efectos que las inversiones internacionales puedan tener en la situación económica de los territorios de los miembros.

Dichos fines se han enriquecido a partir de la evolución del sistema económico mundial, derivando en las instituciones integrantes del grupo anteriormente mencionadas.

Objetivos del Grupo del Banco Mundial. El grupo tiene dos ambiciosos objetivos: terminar con la pobreza extrema en el curso de una sola generación y promover la prosperidad compartida.

- Para acabar con la pobreza extrema, la meta del Banco es disminuir el porcentaje de las personas que viven con menos de 1,25 dólares norteamericanos al día y elevarla al 3\% antes de fines de 2030 .

- Para fomentar la prosperidad compartida, la meta es promover el crecimiento de los ingresos de la población 
de todos los países, que se sitúa en el $40 \%$ inferior de la distribución del ingreso.

El Banco Mundial es una fuente fundamental de asistencia financiera y técnica para los países en desarrollo de todo el mundo. No se trata de un banco en el sentido usual, sino de una organización única que persigue reducir la pobreza y apoyar el desarrollo.

Estructura del Banco Mundial. El Banco Mundial funciona como una cooperativa integrada por 188 países miembros, quienes a través de sus instituciones tienen capacidad de tomar decisiones sobre cualquier asunto, ya sea político, financiero o relativo a su adhesión.

Los países miembros gobiernan el Grupo del Banco Mundial a través de la Junta de Gobernadores y el Directorio Ejecutivo. Estos órganos toman todas las decisiones importantes de las organizaciones.

Estos países o accionistas son representados por una Junta de Gobernadores, el máximo órgano responsable de formular políticas en la institución. Por lo general, los gobernadores son ministros de finanzas o de desarrollo de los países miembros, y se congregan una vez al año en las reuniones anuales de las juntas de gobernadores del Grupo del Banco Mundial y el Fondo Monetario Internacional.

Como los gobernadores se reúnen solo una vez al año, éstos delegan deberes específicos a vienticinco directores ejecutivos que trabajan en la sede central del Banco. Los cinco principales accionistas - Francia, Alemania, Japón, Reino Unido y Estados Unidos - nombran cada uno un director ejecutivo, y los demás países miembros son representados por los otros veinte directores ejecutivos electos restantes.

El presidente del Grupo del Banco Mundial encabeza las reuniones del Directorio y es responsable de la gestión general de la institución. El Directorio Ejecutivo elige al presidente por un periodo renovable de cinco años. 
Los directores ejecutivos componen los directorios ejecutivos del Banco Mundial. Se reúnen normalmente al menos dos veces por semana para revisar las actividades de la institución, incluida la aprobación de préstamos y garantías, nuevas políticas, el presupuesto, las estrategias de asistencia a los países y las decisiones en materia de créditos y cuestiones financieras.

El Banco Mundial opera a diario bajo el liderazgo y la dirección del presidente, la administración y funcionarios superiores y los vicepresidentes a cargo de las oficinas regionales, sectores, redes y funciones.

El máximo órgano rector del BM es la Junta de Gobernadores. Cada país miembro designa un gobernador, generalmente el ministro de Economía o el presidente del Banco Central. Esta Junta se reúne como mínimo una vez al año, y aunque decide formalmente las políticas de Banco al más alto nivel, los gobernadores prácticamente no participan del quehacer diario del Banco. Cuando adoptan decisiones, suelen seguir las recomendaciones del personal técnico y del directorio ejecutivo del Banco. Este directorio es el que controla la política diaria del Banco y aprueba los préstamos después de una compleja y dilatada secuencia de informes y evaluaciones.

Finalmente, el directorio ejecutivo tiene una autoridad máxima, que es a la vez el presidente del BM. Desde su fundación, el Banco ha tenido siempre presidentes de nacionalidad norteamericana, reflejando así el peso específico de esa nación en el aporte de fondos y en las políticas del Banco.

Los fondos de que dispone el Banco para financiar sus préstamos e inversiones provienen fundamentalmente de dos fuentes:

- Los aportes de los diferentes países miembros bajo la forma de capital integrado, que es el dinero que los gobiernos de los países miembros dan directamente al Banco y el capital exigible, que es el que los países se comprometen a otorgar cuando el Banco se lo solicite. 
- Los recursos financieros captados por el Banco en el mercado financiero internacional, mediante la emisión de bonos que, a su vez, tienen por garantía el capital aportado por los diferentes países miembros.

Operación del Banco Mundial. Esta institución no funge el papel de un banco convencional, sino de una organización única, que persigue reducir la pobreza y apoyar el desarrollo al otorgar préstamos con bajo interés, créditos sin intereses y donaciones a los países en desarrollo. Algunos de estos proyectos se cofinancian con, Gobiernos, otras instituciones multilaterales, bancos comerciales, organismos de créditos para la exportación e inversionistas del sector privado, entre otros. También entrega financiamiento mediante asociaciones de fondos fiduciarios con donantes bilaterales y multilaterales.

El Banco Mundial realiza préstamos a países, aunque algunas afiliadas del Banco pueden proveer apoyo directo a negocios privados y organizaciones sin ánimo de lucro. Países con ingresos medios, usualmente con ingresos per cápita entre 1,506 y 5,445 dólares norteamericanos, y países de menores ingresos con algún tipo de "solvencia" piden préstamos al BIRD, Banco Internacional de Reconstrucción y Desarrollo, mientras que los países más pobres, con ingreso per cápita inferior a 885 dólares, piden préstamos a la IDA, Asociación Internacional para el Desarrollo. Los préstamos de la IDA son libres de interés, pero los beneficiarios deben pagar una suma menor al 1\% del préstamo por concepto de costos administrativos.

La Corporación Financiera Internacional (IFG) ofrece financiación de proyectos en el sector privado en países en vías de desarrollo a través de préstamos y capital financiero movilizando mercados internacionales. Cuarenta por ciento de la inversión de la IFG se da en el sector financiero.

El Organismo Multilateral de Garantía de Inversiones (MIGA), provee garantías y seguros en riesgo político a inversionistas pri- 
vados y prestamistas, para fomentar la inversión extranjera directa (IED) en países en vías de desarrollo.

Se puede decir que dependiendo del tipo de proyecto en el que se requiera solicitar apoyo, es la institución del Banco Mundial a la cual debe acudirse.

Para poder solicitar apoyo, las economías deben ser miembros del Banco Mundial. Conforme a lo dispuesto en el Convenio Constitutivo del Banco Internacional de Reconstrucción y Fomento, BIRF, si un país desea ser miembro del Banco primero debe adherirse al Fondo Monetario Internacional, FMI. Para ser miembro de otras organizaciones como la AIF, la IFG y el MIGA, primero hay que ser miembro del BIRF.

Así, los miembros sólo podrán operar con el Banco Mundial a través de sus tesorerías, bancos centrales, fondos de estabilización u otras agencias fiscales similares, y el Banco podrá operar con los miembros únicamente a través de dichos organismos.

El Banco Mundial puede otorgar créditos a cualquier miembro o subdivisión política de éste, o a cualquier empresa comercial, industrial o agrícola en los territorios de un miembro, y cuyo organismo, aceptable para el Banco Mundial, ofrezca plena garantía con respecto al reembolso del capital, al pago de intereses y otros gastos derivados del préstamo, así como evaluando una adecuada tasa de interés y un plan de amortización adecuado al proyecto en cuestión. Además, tomando disposiciones, a fin de asegurar que el importe del préstamo se destine únicamente a los fines para los cuales fue concedido y en el tipo de moneda en el que fue acordado.

Los préstamos que el Banco Mundial llegue a efectuar se regularán mediante un contrato que determinará los términos y condiciones que regirán para el pago de intereses y amortización, el vencimiento y las fechas de pago de cada préstamo. Determinará también la tasa, términos y condiciones referentes a las comisiones que se cargarán a dichos préstamos, la moneda o las monedas en que los pagos contractuales deberán efectuarse al Banco Mundial, y cuando se trate de préstamos concedidos, los contratos respec- 
tivos deberán disponer que los pagos por concepto de intereses, otros cargos y amortización, se efectuarán en la misma moneda prestada. El monto total vigente y pagadero al Banco en una moneda cualquiera no podrá exceder en ningún momento del monto total de los préstamos pagaderos en esa misma moneda.

Si alguno de los miembros acreedores de dicho préstamo tuviera una reducción de divisas, puede solicitar al Banco Mundial que se moderen las condiciones de pago. El Banco podrá, a su discreción, hacer arreglos con el miembro respectivo para aceptar el pago del servicio del préstamo en la moneda de dicho miembro por periodos que no excedan de tres años y en términos convenientes respecto al uso de esa moneda y el mantenimiento de su valor de divisas, así como para la recompra de esa moneda en condiciones adecuadas.

Al conceder una garantía sobre un préstamo, el Banco Mundial cobrará una comisión pagadera periódicamente sobre el saldo vigente del préstamo a una tasa que el Banco determine. Durante los primeros diez años de las operaciones del Banco, esta tasa no podrá ser inferior al $1 \%$ ni superior al $1,5 \%$ anual. $\mathrm{Al}$ término de este periodo de diez años, la tasa de comisión podrá ser reducida por el Banco para los saldos vigentes de préstamos ya concedidos, así como para futuros préstamos, siempre que la reserva acumulada por el Banco fuera considerada por él como suficiente para justificar esa reducción.

En casos de falta de pago de préstamos que el Banco hubiera concedido o garantizado, deberá hacer todos los arreglos factibles, a fin de liquidar las obligaciones derivadas de esos préstamos, y los pagos de obligaciones del Banco deberán ser cargados: primero, a la reserva especial, y en seguida, a otras reservas, utilidades y capital disponible del Banco. Además, si el Banco Mundial cree que una insolvencia puede ser de mayor duración, puede exigir el pago de un monto adicional de las suscripciones insolutas que no exceda, en un año, del 1\% de las suscripciones totales de los miembros. 
Todo este proceso que realiza el Grupo del Banco Mundial para dar financiamiento y cumplir con su cometido ha sido presa de múltiples críticas, sobre todo aquellas en las que la sociedad o los grupos vulnerables de la sociedad se ven afectados, y es precisamente en este punto donde factores como la corrupción fracturan, y el conflicto de intereses de quienes mayor ingreso poseen, todavía no permite que la transparencia de este tipo de organismos internacionales se vea reflejada tal y como la gobernanza; así lo estipula en la manera de promover la equidad, la participación, el pluralismo, la transparencia, la responsabilidad y el estado de derecho, de modo que sea efectivo, eficiente y duradero.

Y es que si bien el Grupo del Banco Mundial como institución que posee personalidad jurídica, tiene como misión favorecer las condiciones de igualdad en los países, eliminar pobreza y fomentar el crecimiento de ingreso de la población, factores como corrupción, pobreza y violencia representan todavía una amenaza para la buena gobernanza.

\section{Fondo Monetario Internacional}

El Fondo Monetario Internacional fue creado en 1944 en Estados Unidos, Nueva Hampshire, e inició sus operaciones en 1946. Actualmente lo integran 188 miembros.

Los objetivos principales del Fondo derivan en:

a) Fomentar la cooperación monetaria internacional.

b) Facilitar la expansión y el crecimiento equilibrado del comercio internacional.

c) Fomentar la estabilidad cambiaria, regímenes de cambios ordenados y evitar depreciaciones cambiarias competitivas.

d) Coadyuvar a establecer un sistema multilateral de pagos.

e) Infundir confianza a los países miembros y poner a su disposición temporalmente y con las garantías adecuadas los recursos generales del Fondo. 
Desde su creación, este organismo ha tenido varias reformas en 1969, en 1978, en 1992, en 2009, y la última reforma en 2011. Estas han fortalecido al FMI y buscan beneficiar más a los países miembros. Entre las más importantes podemos nombrar las siguientes:

- 1969, se creó una nueva fuente de liquidez internacional: los derechos especiales de giro.

- 1971, libre elección de régimen cambiario por cada país, prohibición de fijar una paridad con el oro.

- 1978, ubicación de las oficinas, reuniones de la Junta de Gobernadores, convocatoria a las reuniones de la Junta de Gobernadores, selección del presidente y de los vicepresidentes.

- 1992, modificación de los presupuestos y auditorías.

- 2009, reforma del marco de préstamos del FMI.

- 2010, en el mes de noviembre, el aumento de las cuotas. El traspaso de las cuotas se realizó principalmente mediante una reducción de las proporciones de varias economías avanzadas y países productores de petróleo.

— 2010, reforma del mes de diciembre, "Reestructuración del FMI", reestructura la composición del Directorio Ejecutivo del FMI, mercados emergentes. Los países europeos avanzados tendrán dos directores menos, y todos los directores serán electos, y no designados. El tamaño del Directorio, que seguirá siendo de 24 integrantes, se someterá a examen cada ocho años.

Los gobernadores del FMI considerarán incrementar la flexibilidad de la que disponen los directores que representan a varios países para nombrar un "segundo director ejecutivo suplente", como en el caso de los dos grupos de África subsahariana, y para tomar medidas para garantizar que el número de votos en el FMI siga reflejando las nuevas realidades mundiales.

- 2011, la reforma del régimen de cuotas y representación. 
Obligaciones de los países miembros:

a) Orientar sus políticas económicas y financieras hacia el objetivo de un crecimiento económico ordenado con razonable estabilidad de precios.

b) Acrecentar la estabilidad económica y financiera, un sistema monetario que no tienda a producir perturbaciones erráticas.

c) Evitar manipular los tipos de cambio o el sistema monetario internacional para impedir el ajuste de la balanza de pagos u obtener ventajas competitivas desleales frente a otros países miembros.

d) Seguir las políticas cambiarias compatibles con las obligaciones.

Estructura del Fondo Monetario Iternacional: el Fondo tendrá una Junta de Gobernadores, un Directorio Ejecutivo, un director gerente y el personal correspondiente.

La Junta de Gobernadores es el ministro de Hacienda o gobernador del banco; dentro de sus facultades, ha delegado la mayor parte de éstas en el Directorio Ejecutivo; sin embargo, se reserva:

a) El derecho de aprobar aumentos de cuotas.

b) Asignaciones especiales de derechos de giro, DEG.

c) La admisión de nuevos miembros.

d) La separación obligatoria de miembros.

e) Enmiendas al Convenio Constitutivo y a los estatutos.

f) Elige o nombra a directores ejecutivos.

g) Es la autoridad máxima en cuestiones relacionadas con la interpretación del Convenio Constitutivo del FMI. 


\section{Organización Mundial del Comercio}

La Organización Mundial del Comercio (OMC) es la única organización internacional que se ocupa de las normas que rigen la materia del comercio entre los países. Los pilares sobre los que descansa son los acuerdos de la OMC, que han sido negociados y firmados por la gran mayoría de los países que participan en el comercio mundial, y ratificados por sus respectivos parlamentos. El objetivo es ayudar a los productores de bienes y servicios, los exportadores y los importadores, a llevar adelante sus actividades.

La OMC nació como consecuencia de unas negociaciones, y todo lo que hace es el resultado de negociaciones. La mayor parte de la labor actual de la OMC proviene de las negociaciones celebradas en el periodo 1986-1994 - la llamada Ronda Uruguayy de anteriores negociaciones celebradas en el marco del Acuerdo General sobre Aranceles Aduaneros y Comercio, GATT. La Ronda tuvo como objetivos principales:

- Alcanzar una mayor liberalización del comercio.

- Actualizar y reforzar las reformas del GATT.

- Ampliar su ámbito de aplicación a nuevas áreas de comercio internacional, como la agricultura, los textiles, los servicios y la propiedad intelectual.

La Ronda de Uruguay representó la oportunidad para liberalizar el comercio internacional, reforzar la disciplina y mejorar la transparencia en el sistema multilateral del comercio. Además, pretendió constituir un mecanismo para dirimir las controversias comerciales. Después de más de siete años de haberse iniciado las negociaciones multilaterales, en diciembre de 1993, se concluyó el acta final. Así, tras casi 45 años y nueve meses, la comunidad internacional, en un número de 106 países, llegó a la creación y funcionamiento de una organización internacional que se encargara de administrar el sistema multilateral de comercio. 
El acta final de la Ronda de Uruguay termina con el carácter provisional del GATT de 1947, para crear una verdadera organización internacional, es decir, la Organización Mundial del Comercio, $\mathrm{OMC}$, dotada de personalidad jurídica, órganos propios y de amplias funciones, nacida para facilitar la cooperación de sus miembros en el desarrollo de las relaciones comerciales, donde se integran bajo una misma estructura tres grandes acuerdos: el de Mercancías, GATT, el de Servicios, y el de los Derechos de Propiedad Intelectual, TRIPS; al mismo tiempo, se contemplan dos mecanismos internacionales, así como un mecanismo de examen de las políticas comerciales. ${ }^{107}$

Además, prevé su cooperación con otras organizaciones internacionales, entre las que destacan el FMI y el BM.

El objetivo primordial de la organización consiste en impedir que los países adopten medidas unilaterales en contra de otro miembro. Destacan, entre otros, los siguientes fines: ${ }^{108}$

Elevar los niveles de vida, lograr el pleno empleo y un volumen considerable, en constante aumento de ingresos reales y demanda efectiva.

- Acrecentar la producción y el comercio de bienes y servicios, al mismo tiempo permite la utilización óptima de los recursos mundiales, de conformidad con el objetivo de un desarrollo sostenible, procurando proteger y preservar el medio ambiente, e incrementar los medios para hacerlo, de manera compatible con sus respectivas necesidades e intereses, según los diferentes niveles de desarrollo económico.

- Preservar los principios fundamentales y favorecer la consecución de los objetivos que forman el sistema de la OMC.

107 Quintana Adriano, Elvia Arcelia, El comercio exterior de México. Marco jurídico, estructura y política, cit., pp. 225 y 226.

108 Ibidem, p. 228. 
Actualmente la OMC es esencialmente un lugar al que acuden los gobiernos miembros para tratar de arreglar los problemas comerciales que tienen entre sí. Su núcleo está constituido por los acuerdos de la OMC, negociados y firmados por la mayoría de los países que participan en el comercio mundial. Estos documentos establecen las normas jurídicas fundamentales del comercio internacional. Son esencialmente contratos que obligan a los gobiernos a mantener sus políticas comerciales dentro de límites convenidos. Aunque negociados y firmados por los gobiernos, su objetivo es ayudar a los productores de bienes y servicios, los exportadores y los importadores, a llevar, a cabo sus actividades, permitiendo al mismo tiempo a los gobiernos lograr objetivos sociales y ambientales.

El propósito primordial del sistema es ayudar a que las corrientes comerciales circulen con la máxima libertad posible - siempre que no se produzcan efectos secundarios desfavorables-, porque es importante para el desarrollo económico y el bienestar. Esto significa, en parte, la eliminación de obstáculos. También significa asegurar que los particulares, las empresas y los gobiernos conozcan cuáles son las normas que rigen el comercio en todo el mundo, dándoles la seguridad de que las políticas no sufrirán cambios abruptos.

\section{Cámara de Comercio Internacional (CCI)}

Es la organización empresarial que representa mundialmente intereses empresariales. Se constituyó en París en 1919, y tiene personalidad propia, y su naturaleza jurídica es asociativa.

Sus fines estatutarios básicos son actuar a favor de un sistema de comercio e inversiones abierto y crear instrumentos que lo faciliten, con la firme convicción de que las relaciones económicas internacionales conducen a una prosperidad general y a la paz entre los países.

La misión de la CCI es fomentar el comercio y la inversión entre las empresas del mundo en los distintos sectores, así como 
ayudarlas a enfrentarse a cada uno de los retos y oportunidades que la globalización ofrece.

A través de sus diversas comisiones, la CGI trabaja en ámbitos como: arbitraje, banca, competencia, comercio electrónico, aduanas y facilitación del comercio, seguros y servicios financieros, impuestos, política comercial, y transporte y logística. En estos ámbitos, la CCI lleva a cabo investigación y desarrolla normas y directrices que el sector privado puede aplicar internacionalmente. ${ }^{109}$

La CGI cuenta con garantías internacionales, instrumentos que permiten asegurar el cumplimiento de las obligaciones pactadas por las partes en una relación contractual.

La globalización económica justifica la creación de estos organismos internacionales, con el fin de asegurar las obligaciones contractuales asumidas.

La Cámara de Comercio Internacional (CGI) ha tenido como objetivo poner de manifiesto la utilización de los más importantes instrumentos del comercio internacional, con el fin de lograr una importante seguridad jurídica y ayudar a evitar dudas, errores y confusiones.

Entre las garantías bancarias, en la Cámara de Comercio Internacional se encuentra la Comisión sobre Técnicas y Prácticas Bancarias (CTPB), que es una Comisión dependiente de la Comisión de las Naciones Unidas para el Derecho Mercantil Internacional (CNUDMI) .

Debido a la falta de acuerdo entre los sectores implicados, y en especial entre aquellos partidarios de primar la posición contractual de la entidad bancaria, éstos defendían una mayor toma en consideración de otras partes implicadas en la operación, como los beneficiarios y ordenantes de la garantía. ${ }^{110}$

109 International Chamber of Commerce, véase: wrwr.iccwbo.org/about-us/.

110 Véase sobre el proyecto de 1983, el magnífico trabajo de Sánchez-Calero Guilarte, J., "Proyecto de Código para la práctica de garantías y fianzas a primera demanda", Revista de Derecho Bancario y Bursátil, núm. 13-15, 1984, pp. 51 y ss., 587 y ss. 
Por ello, la Comisión sobre Técnicas y Prácticas Bancarias de la CCI elaboró una serie de Reglas Uniformes relativas a las garantías a primer requerimiento; ${ }^{111}$ en éste se considera el contrato de garantía como un compromiso independiente, autónomo e irrevocable. ${ }^{112}$

México tiene un Comité Nacional dependiente de la CCI, que fue fundado en 1945 como organismo de afiliación voluntaria, destinado a vincular al empresariado mexicano con la comunidad internacional representada en el organismo internacional. ${ }^{113}$

Las comisiones de la CCI México han participado con su experiencia y conocimientos de cada uno de sus integrantes, en diversos trabajos internacionales, en los cuales fue representado por posturas y proyectos de alto nivel; participación en la revisión y realización de traducciones al español de diversos reglamentos, guías y proyectos.

Debido a la participación de la CTPB de ICC México, ésta ha sido considerada como la comisión a nivel mundial más importante, tomando en cuenta que en 2002 se estudiaron diversos proyectos nacionales e internacionales, como fue la incorporación de comercio electrónico a las cartas de crédito, el proyecto de revisión de documentos en procedimientos bancarios, así como los créditos transferibles. ${ }^{114}$

111 Véase Díaz Moreno, A., "Las reglas uniformes de la Cámara de Comercio Internacional sobre garantías «a demanda»", Derecho de los Negocios, núm. 36, 1993, pp. 1-14; Recalde Castells, A., "Las nuevas reglas uniformes sobre «garantías a demanda» de la Cámara de Comercio Internacional", $R D B B$, núm. 48, 1992, pp. 1135-1138;

112 Recuérdese que la principal razón del fracaso de las Reglas de 1978 fue no haber tomado en consideración la primordial característica de las garantías bancarias: su independencia o autonomía respecto de la relación garantizada. En este sentido, Goode, R., Guide to the ICC Uniform Rulesfor Demand Guarantees, París, ICG, 1992, p. 6.

113 ICG México, véase: wrw.iccmex.mx/quienes-somos/icc-mexico/sobre-icc-mexico.

114 ICG México, PAUTA, Boletín informativo del capítulo mexicano de la Cámara Internacional de Comercio, A.C., 17a. Asamblea General de Socios, 3 de octubre de 2002, p. 7. 
Con respecto a la carta de crédito, no se debe olvidar que es un instrumento que cumple con la misma función que cualquier garantía independiente, y los trabajos de la CNUDMI en este ámbito hizo que se elaborara un convenio internacional, que ha sido capaz de albergar instrumentos con una serie de normas de aplicación comunes.

La CCI no había adoptado ninguna medida para promocionar las Reglas Uniformes Relativas a las Garantías a Primer Requerimiento (RUGD). Por ende, la CTPB creó en octubre de 2002 una Task Force específica sobre garantías dedicada tanto a la promoción como a la decisión de incorporarla en todos los modelos de garantías independientes.

Dicha tarea se vio recompensada, ya que gran parte de los bancos europeos más importantes adoptaron las RUGD como reglas subsidiarias en sus modelos de garantía, se plantearon numerosas consultas sobre su aplicación práctica, los bancos de numerosos países del Oriente Medio comenzaron a emitir sus garantías bajo dichas reglas y, en conjunto, se logró una aceptación bastante amplia a nivel mundial de que las RUGD respondían a las necesidades de los distintos participantes en el comercio internacional.

\section{GOBERNANZA EN EL SISTEMA FINANCIERO MUNDIAL}

En el siglo XIX, la tendencia del derecho mercantil se encontraba enmarcada dentro del nuevo impulso de la "Gobernanza Global", que tiene como antecedente el Tratado de Bretton Woods en donde surgen organismos como el Fondo Monetario Internacional, el Banco Mundial, y finalmente, el acuerdo GATT, que posteriormente se convierte en la Organización Mundial del Comercio.

El término "gobernanza" fue empleado por primera vez en Francia en el siglo XII como expresión técnica para asignar la 
administración de jurisdicciones o dominios. Al igual que la palabra "gobierno", viene de "timón" en latín, y expresa la idea de "conducir". Cruzó después el canal hasta Gran Bretaña, para significar el método de organización del poder feudal, que suponía la existencia de señoríos adyacentes entre los que tenía que haber cohesión. No había un poder central como tal, sino un ente, primus inter pares, cuyo propósito era resolver controversias por medios pacíficos y procurar que los intereses en conflicto se conciliaran mediante consultas con los interesados.

El concepto de gobernanza desapareció en el siglo XVI con el surgimiento del Estado, porque los dos conceptos, "gobernanza" y "gobierno", son diferentes. En la gobernanza desaparece la dimensión política que tiene "gobierno". Esta última corresponde a los Estados-nación que surgieron con la paz de Westfalia y a sus respectivos sistemas de gobierno, legitimidad y representación. La gobernanza es un proceso de adopción de decisiones que, a través de la consulta, el diálogo, el intercambio, el respeto mutuo y al derecho nacional, apunta a asegurar la coexistencia y, en algunos casos, la coherencia entre puntos de vista diferentes y a veces discrepantes.

El vocablo "gobernanza" actualmente hace referencia a una nueva forma de gobernar, busca la equidad y la igualdad. Viene utilizándose desde la década de 1990 para designar la eficacia, calidad y buena orientación del Estado, lo que proporciona su legitimidad, y se puede definir como una nueva forma de "gobernar" en la globalización. La rápida difusión del vocablo parece insinuar un cambio en las relaciones de poder, como si fuera insuficiente ya el concepto clásico de gobierno para explicar las transformaciones que se han ido produciendo, que no obedece a una subordinación jerárquica, sino a una integración en red, lo que se ha denominado "redes de interacción".

La gobernanza busca describir una transformación sistémica compleja, que se produce a distintos niveles (local, mundial), y en distintos sectores (público, privado y civil). 
El término "gobernanza" se define como arte o manera jurídica que se propone como objetivo el logro de un desarrollo económico, social e institucional duradero, promoviendo un sano equilibrio entre en Estado, la sociedad y el mercado de la economía.

La gobernanza global refiere a la regulación de relaciones interdependientes en ausencia de una autoridad política global, o sea, la relación entre estados independientes.

La palabra "gobernanza" se utiliza como sinónimo de dirección política, y actualmente su nuevo atractivo y la correspondiente extensión semántica se debe a su capacidad de abarcar la totalidad de las instituciones y relaciones implicadas en el proceso de gobierno, vinculando el sistema político con su entorno. ${ }^{115}$

Para Pascal Lamy, exdirector general de la OMC, al considerar que la OMC es un laboratorio para la gobernanza mundial, afirma que la gobernanza es un proceso de adopción de decisiones, que a través de la consulta, el diálogo, el intercambio y el respeto mutuo, apunta a asegurar la coexistencia y, en algunos casos, la coherencia entre los puntos de vista diferentes, a veces discrepantes, para la cual se hace necesario buscar una base de acuerdo e ir implantándola hasta que aparezca la posibilidad de una acción conjunta. ${ }^{116}$

De acuerdo con el criterio de Rhodes, ${ }^{117}$ el concepto de gobernanza en la actualidad alude a un nuevo estilo de gobierno, distinto del modelo de control jerárquico, pero también del mercado, caracterizado por un mayor grado de cooperación y por la interacción del Estado y los actores no estatales en el interior de redes decisionales mixtas entre lo público y lo privado. Implica un cambio de sentido de gobierno, un nuevo método conforme al cual se gobierna la sociedad.

115 Natera Peral, Antonio, "Nuevas estructuras y redes de gobernanza", $R e^{-}$ vista Mexicana de Sociología, México, vol. 2005, núm. 4, 2005.

116 Pascal Lamy, "La OMC: laboratorio para la gobernanza mundial", disponible en: http://wwrw.wto.org/spanish/news_s/spp147_s.htm.

117 Rhodes, R. A. W., Understanding Governance, Buckingham and Philadelphia, Open University Press, 1997, capítulo 3. 
Para Kooiman y Van Vliet, 118 el concepto de "gobernanza" apunta a la creación de una estructura o un orden que no se puede imponer desde el exterior, sino que es el resultado de una interacción de una multiplicidad de agentes dotados de autoridad y que influyen los unos en los otros. La gobernanza no se caracteriza por la jerarquía, sino por la interacción de actores cooperativos autónomos y por redes entre organización. Koomai, por su parte, propone definir a la gobernanza como "los patrones y estructuras que emergen en un sistema sociopolítico, como el común resultado de los esfuerzos de intervención interactiva de todos los actores implicados". ${ }^{119}$

De acuerdo con el criterio de Antonio Natera, ${ }^{120}$ la "gobernanza" se refiere a las estructuras y procesos mediante los cuales los actores políticos y sociales llevan a cabo prácticas de intercambio, coordinación, control y adopción de decisiones en los sistemas democráticos.

Principios de la gobernanza. La buena gobernanza promueve la equidad, la participación, el pluralismo, la transparencia, la responsabilidad y el Estado de derecho, de modo que éste sea efectivo, eficiente y duradero.

El sistema de la Naciones Unidas promueve la buena gobernanza a través de diferentes vías, como el Programa de las Naciones Unidas para el Desarrollo (PNUD), en el que apoya activamente los procesos nacionales de transición democrática.

Características de la gobernanza: a) legitimidad: se refiere a que está reconocido por alguna autoridad; $b$ ) transparencia: se refiere a que las decisiones que se llevan sean conforme a las leyes establecidas; c) responsabilidad: el buen gobierno requiere que las instituciones y los sistemas sirvan a todos los grupos de interés;

118 Kooiman, Jan y Martin van Vliet, "Self-Governance as a Mode Societal Governance", Public Management: An International fournal of Research and Theory, vol. 2, núm. 32, 2000, pp. 359-377.

119 Idem.

120 Natera Peral, Antonio, "Nuevas estructuras y redes de gobernanza", Revista Mexicana de Sociología, México, vol. 2005, núm. 4, 2005. 
d) equidad: consiste en asegurar que todos los miembros se sientan parte de la misma y no se sientan excluidos, y e) eficacia: se refiere a que un buen gobierno alcance sus objetivos mediante sus procedimientos y estrategias implantados.

La buena gobernanza es el escenario idóneo para la distribución de manera equitativa de los beneficios del crecimiento económico.

\section{El papel de la gobernanza en la globalización}

La gobernanza se considera buena y democrática en la medida en que las instituciones y los procesos de cada país sean transparentes. Los procesos incluyen actividades fundamentales como elecciones de procesos legales, los cuales deben estar exentos de corrupción, y deben ser responsables ante el pueblo. El cumplimiento de esta normativa se ha convertido en un conjunto de normas establecidas convencionalmente para evaluar y medir la credibilidad y el respeto de los países. Además, apoya las campañas públicas de información y fomenta y entabla el diálogo; facilita las redes de conocimientos y la divulgación de información sobre las prácticas idóneas.

$\mathrm{Al}$ entender la globalización como un proceso complejo que varía en el tiempo, y que afecta indistintamente a los sectores de producción de los países, y puede alterar los entornos nacionales bajo diferentes esquemas, se hace necesario analizar cómo se ha presentado tanto en el ámbito comercial como en la información, capital, bienes, servicios e ideas plasmadas a través de la integración de organismos internacionales, como la Organización de las Naciones Unidas, ONU, el Fondo Monetario Internacional, el FMI, el Banco Mundial (BM) y la Organización Mundial del Comercio (OMG).

Actualmente, la globalización de los mercados financieros integrados por empresas constituidas por capital, bienes o servicios e información, tratan de conseguir fondos de cualquier país, y no 
limitarse a los mercados financieros domésticos ni tampoco los inversionistas de un país que se encuentran restringidos a invertir en el mismo.

Cabe resaltar que los factores que llevan a la integración de los mercados financieros a nivel mundial son:

1) La liberalización de los mercados y de las actividades de los participantes en los mismos dentro de los principales centros financieros del mundo.

2) Los avances tecnológicos para monitorear los mercados mundiales, ejecutar órdenes y analizar las oportunidades financieras.

3) La institucionalización cada vez mayor de los mercados financieros.

En cualquier mercado global y operativo se requiere tener un entorno legal que resuelva adecuadamente los aspectos de seguridad y privacidad, tendente a proporcionar validez jurídica en la prestación de los servicios financieros, con el fin de evitar la aparición o consolidación de leyes nacionales restrictivas o incompatibles que dificulten el comercio a partir de la internacionalización de los mencionados servicios.

Por esto, la internacionalización de los servicios financieros pretende favorecer la implantación de sistemas financieros más estables y eficaces, por cuanto alude a la introducción de normas y prácticas internacionales, donde destaca la calidad, eficiencia y alcance de estos servicios, facilitando fuentes más estables de fondos a partir de la eliminación del trato discriminatorio que existe entre los proveedores extranjeros de servicios financieros y los nacionales, así como en la supresión de los obstáculos al suministro transfronterizo que revisten esta clase de servicios, permitiendo con tales acciones abrir las puertas para la entrada de proveedores extranjeros en el mercado doméstico.

La internacionalización del capital da lugar a corrientes de capital menos distorsionadas y volátiles, al tiempo que promueve 
la estabilidad del sector financiero, en un mercado tanto interno como internacional, a partir de los lineamientos establecidos por el BM, el FMI y la OMC, esta última establece los principios que debe seguir el sector de servicios financieros a través del Acuerdo General sobre el Comercio de Servicios, AGCS, permitiendo con esto a los países otorgar una credibilidad adicional a sus planes de liberalización del sistema financiero.

La gobernanza a nivel mundial en el sistema financiero se manifiesta a través de tres organismos: el FMI, el BM y la OMC. Estos organismos, creados en el ámbito financiero, comercial, económico y político, buscan la adopción de decisiones a través de la consulta, el diálogo, el intercambio, el respeto mutuo entre diferentes derechos nacionales; tratan de obtener acciones conjuntas que los beneficien ante la perspectiva de la globalización que pone de manifiesto intereses comunes.

La internacionalización de los servicios financieros facilita fuentes más estables a partir de la eliminación del trato discriminatorio que existe entre los proveedores extranjeros de servicios financieros y los nacionales; y fomenta la supresión de los obstáculos al suministro transfronterizo que revisten esta clase de servicios.

En el caso de México, dentro de las responsabilidades que tiene el presidente de la República, Poder Ejecutivo, cabe la de ejercer la rectoría económica del país, con el único y exclusivo objetivo de conseguir para los mexicanos la justa distribución del ingreso y la riqueza; así como fomentar las fuentes de empleo, entre otras actividades tendentes a lograr el objetivo.

Para lograr el objetivo anterior, actúan dentro del área económica estratégica tanto el sector público como el privado, mixto, y en el área económica prioritaria participan el sector privado y el social. Como eje del desarrollo económico-financiero se encuentra el Banco de México, BM y la Secretaría de Hacienda y Crédito Público, SHCP. 


\section{BIBLIOGRAFÍA}

BANCO DE MÉXICO, Glosario, disponible en: http://wrere.banxico.org. $\mathrm{mx} /$ divulgacion/glosario/glosario.html.

Barboza, Julio, Derecho internacional público, Buenos Aires, Zavalía, 1999.

Calvo Hornero, Antonio, Organismos financieros internacionales: bancos regionales de desarrollo e instituciones financieras multilaterales, Huelva, Universidad de Huelva, 2000.

Cortina Ortega, Gonzalo, Prontuario bursátily financiero, México, Trillas, 1988.

DiEz DE VELASco, Manuel, Las organizaciones internacionales, Madrid, Tecnos, 1994.

FUENTE RODRÍGUEZ, Jesús de la, Tratado de derecho bancario y bursátil, 6a. ed., México, Porrúa, 2010, t. II.

KoOIman, Jan y VAn Vliet, Martin, "Self-Governance As a Mode Societal Governance", Public Management: An International Fournal of Research and Theory, vol. 2, núm. 32, 2000.

InSTITUTO DE INVESTIGACIONES JURÍDICAS, Enciclopedia Furídica Latinoamericana, México, UNAM, Instituto de Investigaciones Jurídicas-Porrúa, 2006.

LUDLOW, Leonor y SILVA, Rique, La primera etapa de formación bancaria (1864-1897). Parte de los negocios y las ganancias de la colonia al México moderno, México, Instituto de Investigaciones Dr. José María Luis Mora, UNAM, Instituto de Investigaciones Históricas, 1993.

MEJAN GARRER GAMP, Luis Manuel, Instituciones jurídicas del sistema financiero mexicano, tesis doctoral, México, UNAM, 2007. 
NATera Peral, Antonio, "Nuevas estructuras y redes de gobernanza”, Revista Mexicana de Sociología, México, vol. 2005, núm. 4, 2005.

Ortega Castro, Alfonso, Introducción a las finanzas, México, McGraw-Hill, 2002.

Ochod Setzer, Guadalupe, Administración financiera, México, McGraw-Hill, 2002.

QUintana ADriano, Elvia Arcelia, "Marco jurídico constitucional del comercio mexicano", en RABASA, Emilio O. (coord.) Ochenta años de vida constitucional en México, México, UNAM, Instituto de Investigaciones Jurídicas-Cámara de Diputados, LVII Legislatura, 1998.

Quintana Adriano, Elvia Arcelia, El comercio exterior de México. Marco jurídico, estructura y política, 3a. ed. (corregida y aumentada), México, Porrúa, UNAM, 2010.

Quintana Adriano, Elvia Arcelia, Ciencia del derecho mercantil. Teoría, doctrina e instituciones, 3a. ed., México, Porrúa-UNAM, 2015.

QUintana ADriano, Elvia Arcelia, Derecho de los usuarios de la banca, 3a. ed., México, Cámara de Diputados, LVII LegislaturaUniversidad Nacional Autónoma de México, Instituto de Investigaciones Jurídicas, 2013.

QUintana Adriano, Elvia Arcelia, Legislación mercantil. Evolución histórica, México 1325-2005, México, Porrúa, UNAM, 2005.

QUINTANA ADRIANO, Elvia Arcelia, "Los servicios financieros en México y la OMC", Boletín Mexicano de Derecho Comparado, México, núm. 111, 2004.

QUintana Adriano, Elvia Arcelia, Aspectos legales y económicos del rescate bancario en México, UNAM, Instituto de Investigaciones Jurídicas, 2003.

QUiNTANA ADRIANO, Elvia Arcelia, Las cédulas hipotecarias rurales, tesis de licenciatura, México, UNAM, 1969.

Rhodes, R. A. W., Understanding Governance, Buckingham and Philadelphia, Open University Press, 1997. 
INSTITUTO DE INVESTIGACIONES JURÍDICAS, Enciclopedia furídica Mexicana. Léxico bancario, México, Porrúa-UNAM, Instituto de Investigaciones Jurídicas, 2004.

INSTITUTO DE INVESTIGACIONES JURÍDICAS, Enciclopedia furídica Mexicana, México, Porrúa-UNAM, Instituto de Investigaciones Jurídicas, 2002. 
ANEXOS 


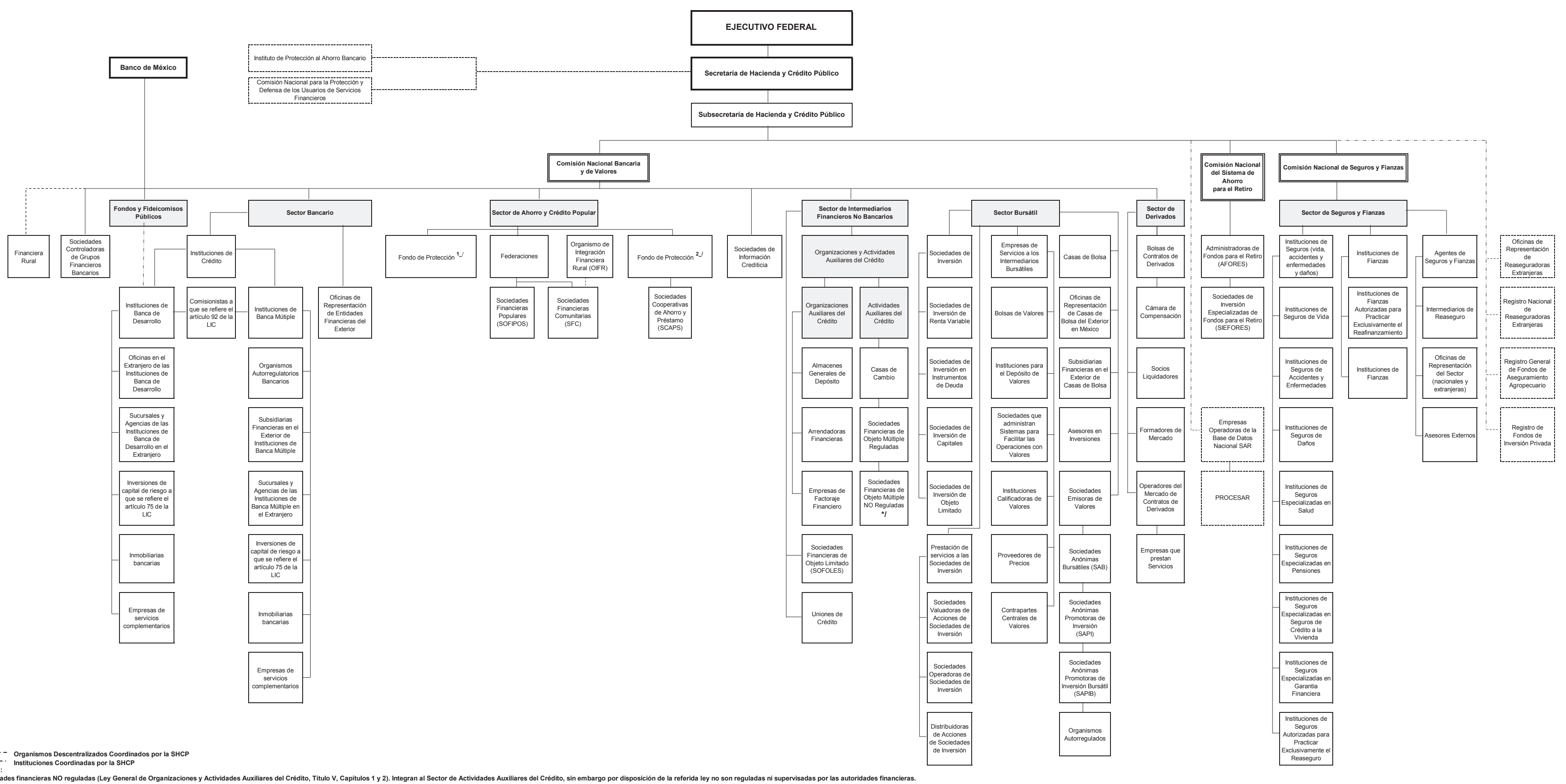


ANEXOS

\section{GRUPOS FINANCIEROS}

\begin{tabular}{|l|}
\hline \multicolumn{1}{|c|}{ Ley para Regular } \\
las Agrupaciones Financieras
\end{tabular}

Integración

- Sociedad controladora y

- Cuando menos dos de las entidades financieras
Grupo financiero

们

Concepto

"Agrupación integrada por la sociedad controladora y por entidades financieras, autorizada por la Secretaría de Hacienda y Crédito Público"

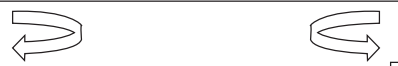

- Almacenes generales de depósito

- Casas de cambio

- Instituciones de fianzas

- Instituciones de seguros

- Casa de bolsa

- Instituciones de banca

múltiple

- Sociedades operadoras

de fondos de inversión

- Administradoras de

fondos para el retiro

- Sociedades financieras

de objeto múltiple

- Sociedades financieras

populares

\begin{tabular}{|l|}
\hline Solicitud de autoriza- \\
ción ante la Secreta- \\
ría de Hacienda y \\
Crédito Público \\
\hline
\end{tabular}




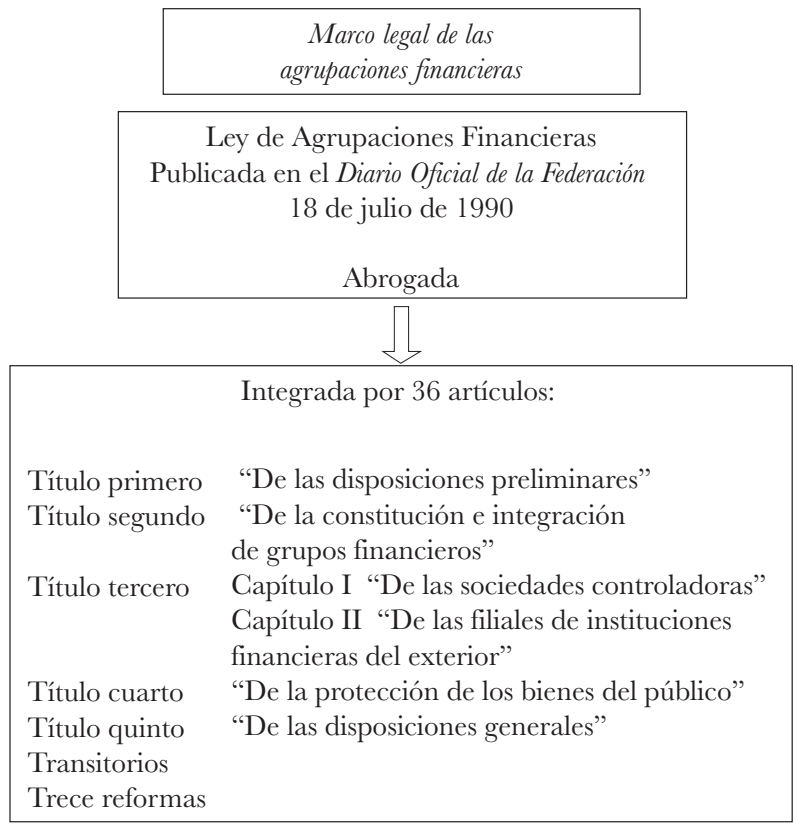

Actuar de manera conjunta frente al público, ofrecer servicios complementarios y ostentarse como integrantes del grupo financiero de que se trate.

\begin{tabular}{c}
\hline Entidades financieras \\
integrantes de un grupo \\
financiero
\end{tabular}

Usar denominaciones iguales o semejantes que los identifiquen frente al público como integrantes de un mismo grupo financiero, o bien, conservar la denominación que tenían antes de formar parte de dicho grupo financiero. En todo caso deberán añadir las palabras "grupo financiero" y la denominación del mismo.

Llevar a cabo operaciones que les son propias a través de oficinas y sucursales de atención al público de otras entidades financieras integrantes del grupo financiero. 


\section{Ley de Agrupaciones Financieras \\ Publicada en el Diario Oficial de la Federación \\ el 10 de enero de 2014 \\ Vigente}

Integrada por 193 artículos:

Título primero

Título segundo

Título tercero

Título cuarto

Título quinto

Título sexto

Título séptimo

Título octavo

Título noveno
De las disposiciones preliminares.

De la organización de las sociedades controladoras y la constitución y funcionamiento de grupos financieros.

Capítulo I. De la organización.

Capítulo II. Del funcionamiento.

Capítulo III. De la administración. Sección I, el deber de diligencia.

Sección II. Del deber de lealtad y de los actos o hechos ilícitos.

Sección III De las acciones de responsabilidad.

Capítulo IV. De la vigilancia.

Capítulo V. De la gestión, conducción y ejecución de los negocios de los sociales.

Capítulo VI. De las asambleas de accionistas y derechos de los socios. De las filiales de instituciones financieras del exterior

De la oferta de servicios conjuntos. Capítulo único. Del uso de instalaciones y de la oferta conjunta de servicios financieros Capítulo I. De las inversiones de la sociedad controladora en general. Capítulo II. De las inversiones en entidades financieras que no sean integrantes del grupo financiero.

Capítulo III. De las inversiones de prestadoras de servicio e inmobiliarias.

De la protección de los intereses del público.

Capítulo I. De la regulación y supervisión.

Capítulo II. De las responsabilidades y medidas correctivas.

De la revocación, liquidación, separación e intervención

de grupos financieros.

Capítulo I. De la revocación.

Capítulo II. De la disolución, liquidación y del concurso mercantil.

Capítulo III. De la intervención.

De los procedimientos administrativos.

Capítulo I. Disposiciones preliminares.

Capítulo II. De la imposición de sanciones administrativas.

Capítulo III. De los delitos.

Capítulo IV. De las notificaciones.

De los consejos de coordinación de autoridades financieras.

Capítulo I. De los consejos de coordinación para el desarrollo

del sistema financiero.

Capítulo II. Del Consejo de Estabilidad del Sistema Financiero.

Capítulo III. Del Consejo Nacional de Inclusión Financiera.

Capítulo IV. Del Comité de Educación Financiera.

Capítulo V. Del intercambio de información.

Disposiciones transitorias 
ANEXOS

Ciclo de constitución

de un grupo financiero

\begin{tabular}{|c|c|c|}
\hline $\begin{array}{c}\text { Solicitud de } \\
\text { autorización } \\
\text { SHCP }\end{array}$ & $\begin{array}{c}2 \\
\text { Aprobados estatutos } \\
\text { sociales, el convenio } \\
\text { único de responsabili- } \\
\text { dades o modificacio- } \\
\text { nes SHCP }\end{array}$
\end{tabular}$\Rightarrow \begin{gathered}3 \\
\text { Inscripción } \\
\text { del instrumento } \\
\text { público en el } \\
\text { Registro Público } \\
\text { de Comercio }\end{gathered}$

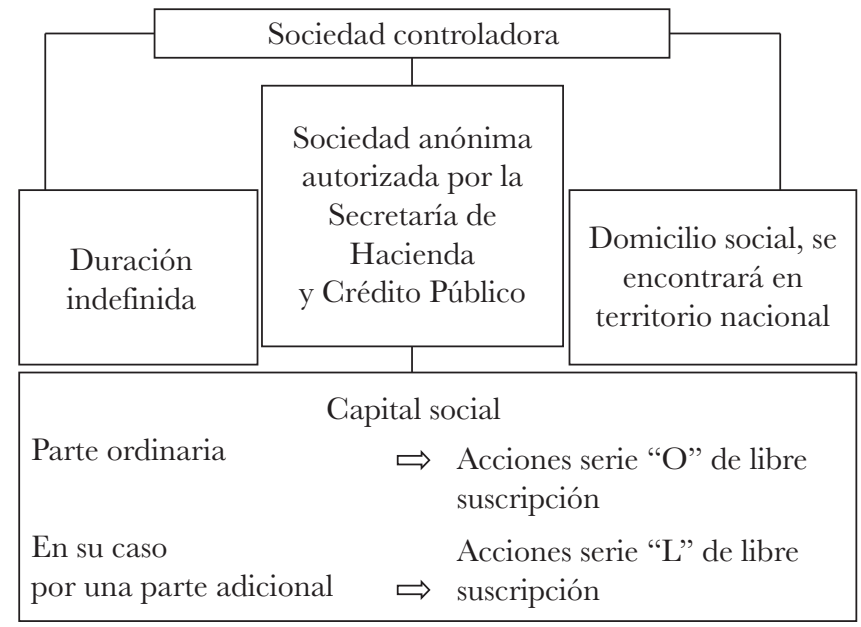




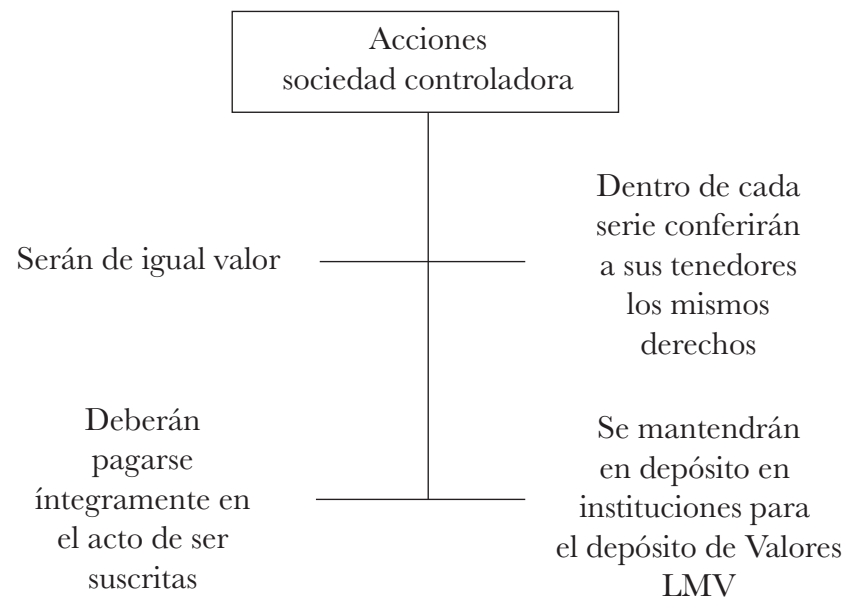

\begin{tabular}{l|l|}
\cline { 2 - 2 } \multicolumn{1}{c|}{} & \multicolumn{2}{c|}{ Acciones serie "L" } \\
$\begin{array}{l}\text { Serán de voto limitado y } \\
\text { otorgarán derecho de voto en: }\end{array}$ & $\begin{array}{l}\text { Podrán conferir derecho a } \\
\text { recibir un dividendo preferen- } \\
\text { a) Cambio de objeto } \\
\text { b) Fusión } \\
\text { c) Escisión }\end{array}$ \\
d) Transformación & dividendo superior al de las \\
e) Disolución & acciones representativas del \\
f) Liquidación & capital social ordinario siem- \\
g) Cancelación de & pre y cuando los establezcan \\
sus inscripción & en los estatutos de la sociedad \\
emisora.
\end{tabular}


Marco jurídico de las finanzas, editado por el Instituto de Investigaciones Jurídicas y la Facultad de Contaduría y Administración de la UNAM, se terminó de imprimir el 30 de agosto del 2018 en los talleres de ??? ??????. Se utilizó tipo Baskerville en 9, 10 y 11 puntos. En esta edición se empleó papel book cream de 60 gramos para los interiores y cartulina couché de 250 gramos para los forros. Consta de 500 ejemplares (impresión offset). 


\begin{abstract}
Esta obra contempla no sólo la estructura del sistema financiero mexicano, sino que explica de manera clara y sustancial la legislación aplicable dentro del panorama general del sistema financiero del país. De una manera metódica y precisa introduce al lector a las instituciones y normas que las rigen, y al objetivo mismo que regula la materia del sistema financiero en sus grandes campos de estudio: instituciones bancarias, instituciones bursátiles, instituciones de seguros y fianzas, así como organismos auxiliares que apoyan el desarrollo de la fluidez del crédito y el dinero. Con el mismo método se hace referencia a las responsabilidades que dentro del derecho tienen las autoridades que gobiernan, dirigen y supervisan las actividades de cada uno de estos campos en beneficio del desarrollo económico del país y de los mexicanos.

Por lo anterior, este libro es de consulta y lectura obligadas tanto para los estudiantes como para los estudiosos de carreras afines a los programas académicos de derecho.
\end{abstract}

